\title{
Characterization of inflammation in COPD : clinical and experimental approach
}

Citation for published version (APA):

Vernooy, J. H. J. (2003). Characterization of inflammation in COPD : clinical and experimental approach. [Doctoral Thesis, Maastricht University]. Universiteit Maastricht. https://doi.org/10.26481/dis.20030502jv

Document status and date:

Published: 01/01/2003

DOI:

10.26481/dis.20030502jv

Document Version:

Publisher's PDF, also known as Version of record

\section{Please check the document version of this publication:}

- A submitted manuscript is the version of the article upon submission and before peer-review. There can be important differences between the submitted version and the official published version of record.

People interested in the research are advised to contact the author for the final version of the publication, or visit the DOI to the publisher's website.

- The final author version and the galley proof are versions of the publication after peer review.

- The final published version features the final layout of the paper including the volume, issue and page numbers.

Link to publication

\footnotetext{
General rights rights.

- You may freely distribute the URL identifying the publication in the public portal. please follow below link for the End User Agreement:

www.umlib.nl/taverne-license

Take down policy

If you believe that this document breaches copyright please contact us at:

repository@maastrichtuniversity.nl

providing details and we will investigate your claim.
}

Copyright and moral rights for the publications made accessible in the public portal are retained by the authors and/or other copyright owners and it is a condition of accessing publications that users recognise and abide by the legal requirements associated with these

- Users may download and print one copy of any publication from the public portal for the purpose of private study or research.

- You may not further distribute the material or use it for any profit-making activity or commercial gain

If the publication is distributed under the terms of Article $25 \mathrm{fa}$ of the Dutch Copyright Act, indicated by the "Taverne" license above, 
Characterization of inflammation in COPD

Clinical and experimental approach

Juanita Henriëtta Jacqueline Vernooy 
ISBN 90-9016781-1

(6) Copyright 2003 Juanita H.J. Vernooy, Brunssum

All rights reserved. No part of this book may be reproduced or transmitted, in any fiorm or by any means, without written permission from the author.

Lay-out: Juanita H.J. Vernooy

Cover illustration: Michèle Lieffroy, Paris, France

Cover design: Juanita H.J. Vernooy

Printed by: Datawyse Boekproducties, Maastricht

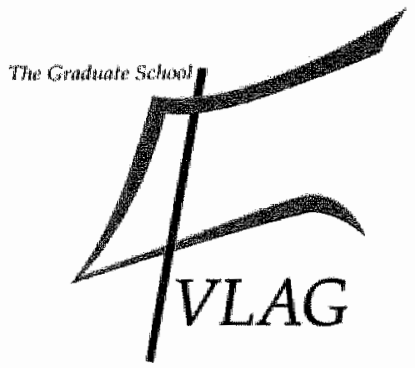

The sludies presented in this thesis were performed at the Nutrition and Toxicology Research Institute Maastricht (NUTRIM), which participates in the Graduate School VLAC (Food Technology. Agrobiotechnology, Nutrition, and Health Sciences), accredited by the Royal Netherlands Academy of Arts and Sciences (KNAW). 


\title{
Characterization of inflammation in COPD
}

\section{Clinical and experimental approach}

\author{
PROEFSCHRIFT
}

ter verkrijging van de graad van doctor aan de Universiteit Maastricht, op gezag van de Rector Magnificus Prof. dr. A.C. Nieuwenhuijzen

Kruseman, volgens het besluit van het College van Decanen, in het openbaar te verdedigen op vrijdag 2 mei 2003 om 12.00 uur

door

Juanita Henriëtta Jacqueline Vernooy 


\section{Promotor:}

Prof. dr. E.F.M. Wouters

Prof. dr. W.A. Buurman

Co-promotor:

Dr. M.A. Dentener

Beoordelingscommissie:

Prof. dr. J.W. Cohen Tervaert (voorzitter)

Prof dr. C.A. Bruggeman

Prof. dr. R. Louis (CHU Sart-Tilman, Luik, Belgiê)

Prof. dr. F.P. Nijkamp (Universiteit Utrecht)

Prof. dr. F.J. van Schooten

The publication of this thesis was financially supported by: ICTopus BV, Stichting Pulmonologie, Stichting Hornerheide, Glaxo Wellcome, APORA, Boehringer Ingelheim/Pfizer, AstraZeneca, Dr. Ir. van de Laar Stichting, Leica Microsystems BV, Zambon Nederland BV „Beun-De Ronde BV. 
Denken is makkelijk, maar doen is moeilijk, en om je gedachten om te zetten in daden is het moeilijkste ter wereld

Johann Wolfgang von Goethe Schrijver, fllosoof en wetenschapper

Ter nagedachtenis aan Pap Voor Mam Voor Alex 


\section{Table of Contents}

CHAPTER 1 General introduction

CHAPTER 2 Aims and outline of the thesis

CHAPTER 3 Local and systemic inflammation in patients with chronic obstructive pulmonary disease: soluble TNF-receptors are increased in sputum

CHAPTER 4 Local and systemic acute-phase response in COPD

CHAPTER 5 Leptin as local inflammatory marker in COPD

CHAPTER 6 Increased activity of matrix metalloproteinase (MMP)-8 and MMP-9 in induced sputum from patients with COPD

CHAPTER 7 Intratracheal instillation of lipopolysaccharide in mice induces apoptosis in bronchial epitheliall cells: no role for TNF- $\alpha$ and infiltrating neutrophils

CHAPTER 8 Rapid expression of acute-phase reactants in lung after local LPS exposure in mice

CHAPTER 9 Long-term intratracheal lipopolysaccharide exposure in mice results in chronic lung inflammation and persistent pathology

CHAPTER 10 Discussion and future directions

CHAPTER 11 Summary

CHAPTER 12 Nederlandse samenvatting

APPENDICES Abbreviations

Dankwoord

List of publications

Curriculum vitae 


\section{CHAPTER 1}

\section{General introduction}

\section{CHRONIC OBSTRUCTIVE PULMONARY DISEASE}

\subsection{Prevalence and health care costs}

Chronic obstructive pulmonary disease (COPD) is a complex heterogeneous respiratory disease, characterized by the progressive development of airflow limitation that is largely irreversible ${ }^{1,2}$. Three conditions comprise COPD, namely chronic bronchitis (mucus hypersecretion), chronic bronchiolitis (small airway disease), and emphysema (alveolar destruction). The contribution of each component to airflow limitation, pathophysiology, and clinical symptoms varies between individual patients. COPD represents a major and growing health care problem. To date, COPD is the fourth leading cause of death in the Netherlands, and will be the third leading cause worldwide in 2020 , with an expected mortality of 4.7 million persons annually $y^{4}$. Reasons for the dramatic increase in COPD prevalence in the next 20 years include a marked increase in cigarette smoking and environmental pollution in developing countries, along with reduced mortality from other causes, such as cardiovascular diseases in industrialized countries and infectious diseases in developing countries ${ }^{5}$. In the Netherlands, approximately 73 per 1000 persons are diagnosed with COPD. The clinical characteristics of COPD (a rapid decline in lung function or persistently decreased lung function) are observed in $20 \%$ of the general adult population in the Netherlands ${ }^{6}$. Moreover, the total COPD-related medical costs are a major burden for the Dutch health care system. The direct costs of COPD represent $1.3 \%$ of the Dutch health care budget and are expected to increase by $60 \%$ in the near future, mostly due to aging of the population?

\subsection{Risk factors}

Risk factors for COPD are thought to include both host factors and environmental exposures, and the disease is suggested to arise from an interaction between these two types of factors ${ }^{4}$. The best-documented host factor for the development of COPD is hereditary severe $\alpha_{1}$-antitrypsin $\left(\alpha_{1}-\mathrm{AT}\right)$ deficiency, as shown by a proteinase inhibitor phenotype (PiZZ) with $\alpha_{1}$-AT levels below $10 \%$ of normal values. Lack of this serum protein, which can be inherited as an autosomal recessive trait, can be associated with accelerated decline of development of emphysema (not chronic airway diseases) in non-smokers, and a markedly accelerated rate in smokers. However, less than $1 \%$ of patients with COPD has severe $\alpha_{1}$-AT deficiency ${ }^{9}$. In addition, many other genetic variants of $\alpha_{1}$-AT that are 
associated with lower-than-normal serum levels of this proteinase inhibitor have not been clearly associated with an increased risk for COPD.

Cigarette smoking is widely recognized as the most important environmental risk factor leading to the development of COPD. Age at starting to smoke, total pack-years smoked, and current smoking status are predictive of COPD mortality". The presence of harmful compounds in inhaled cigarette smoke is considered to be the starting point of the pathogenetic pathway in COPD. In industrialized countries, smoking accounts for as much as 80 to $85 \%$ of cases of COPD. There is a considerable variation among individuals in susceptibility to cigarette smoke, as only $10-20 \%$ of smokers will develop clinically symptomatic COPD, herby suggesting the importance of undefined genetic factors in the development of COPD ${ }^{10}$. In these so-called susceptible smokers, the rate of decline of lung function, measured as the forced expiratory volume in 1 second $\left(\mathrm{FEV}_{1}\right)$, shows a strong relationship with the total pack-years smoked'. As shown in Figure $1^{11}$, smoking cessation is associated with a reduction in the accelerated rate of decline in $F E V_{1}$. This reduction was shown to be the largest for younger subjects and decreased linearly with age ${ }^{12}$. Recent data from the Lung Health Study demonstrated that the subsequent rate of decline of $\mathrm{FEV}_{1}$ among sustained quitters was half the rate among continuing smokers in both male and female $\mathrm{e}^{13,14}$. In addition, smoking cessation was found to be associated with significant reductions in cardiovascular morbidity and mortality ${ }^{15}$. Therefore, quitting smoking is an important therapeutic intervention both to reduce symptoms in patients and, even more important, to prevent the development of COPD. However, the slope of lung function decline remains increased in susceptible exsmokers when compared to non-smokers cq. non-susceptible smokers. As a result, many susceptible ex-smokers, who are currently not symptomatic, will still develop COPD in the future.

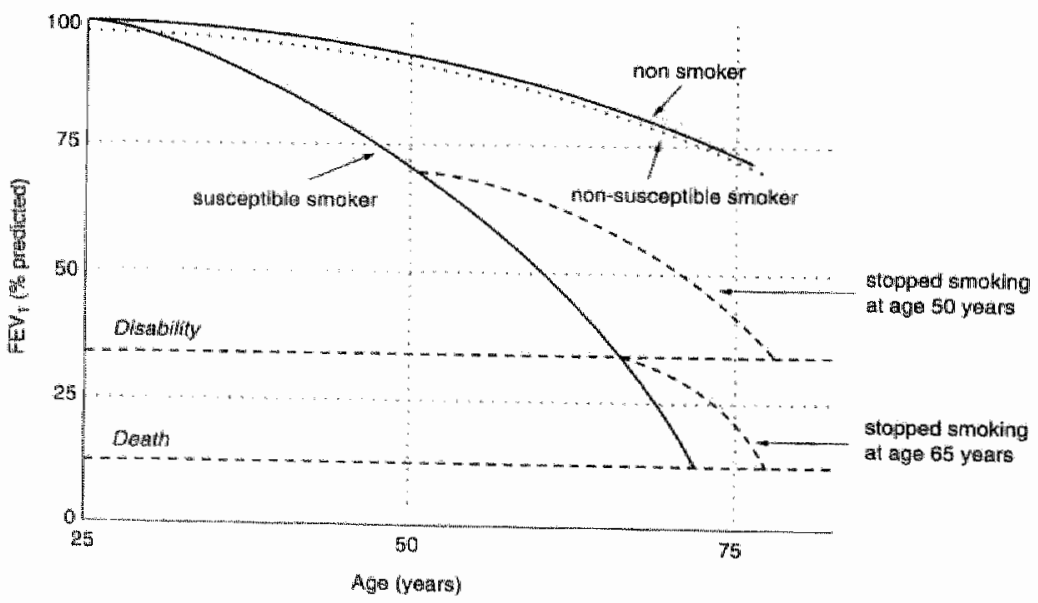

Figure 1. Annual decline in lung function is accelerated in patients with COPD". 
Occupational exposures to organic dust, such as grain dust, swine dust, and cotton dust, have also been associated with development and/or progression of COPD when the exposures are sufficiently intense or prolonged. Such exposures can both cause COPD independently of cigarette smoking and increase the risk in the presence of concurrent cigarette smoking ${ }^{16}$. For example, follow-up studies have shown that long-term exposure to grain dust or swine dust causes a profound pulmonary inflammatory response related to respiratory symptoms and accelerated longitudinal decline in lung function ${ }^{17}$, and thus irreversible and progressive lung pathology. Exposure-response studies have shown that these respiratory symptoms and declines in lung function are dose-dependent ${ }^{18,19}$.

Furthermore, exposures to sufficient levels of anorganic dusts is suggested to be a risk factor to develop COPD. For example, cumulative respiratory exposure to coal or gold dust is associated with loss of lung function in miners ${ }^{20}$. In addition, several cross-sectional studies consistently found a higher prevalence of symptoms of hypersecretion, breathlessness, or diagnosis of chronic bronchitis, emphysema, or COPD in areas with higher urban air poliution (sulfur dioxide, ozone, $_{r}$ and particulates $)^{2 t}$.

Next to the factors mentioned above, a number of other factors are likely associated with development of COPD. These include passive smoke exposure, respiratory virus infection, exposure to occupational chemicals (like cadmium), indoor cooking, socioeconomic factors, nutrition, alcohol ingestion, age, gender, mucus hypersecretion, and airway hyperresponsiveness (reviewed in detail by Buist and Vollmer ${ }^{22}$ ).

\subsection{Pathogenesis}

There is strong evidence that COPD is associated with a chronic inflammatory response throughout the airways, lung parenchyma, and pulmonary vasculature, which is initiated by the inhalation of noxious particles and gases such as those present in cigarette smoke. considerable capacity to repair itself ${ }^{23}$, but these mechanisms may be affected by the genetic background or (repeated) exposure to environmental risk factors. The chronic inflammatory response is characterized by cellular inflammatory infiltrates as well as production of inflammatory mediators, proteinases, and reactive nitrogen and oxygen species. The latter molecules may be produced by inflammatory cells or they may arise from environmental factors. The intensity and characteristics (both cellular and molecular) of the inflammation vary as the disease progresses. The pathologic changes characteristic for COPD are eventually caused either directly by inhaled noxious particles, or, indirectly by the action of inflammatory mediators ${ }^{4}$.

\section{Inflammatory cells}

Many studies reveal a correlation between the number of inflammatory cells of various types in the lung and the severity of COPD ${ }^{2429}$. However, the types of inflammatory cells vary in the different compartments of the lung. Neutrophils are short-lived, transient cells that are recruited directly from peripheral blood to the 
airways. A marked increase in neutrophils in sputum and bronchoalveolar-lavage (BAL) fluid, reflecting neutrophilia in the airway compartment ${ }^{30}$, was demonstrated in COPD patients compared to controls ${ }^{26,27}$. The extent of neutrophilia correlated with the degree of airlow limitation ${ }^{27,28,37}$. In addition, ellevated levels of neutrophil granule proteins, such as myeloperoxidase (MPO) and human neutrophil lipocalin (HNL), were demonstrated in induced sputum and BAL fluid from severe COPD patients and smoking subjects with subclinical emphysema, respectively, indicating activation of recruited neutrophils ${ }^{32,33}$. In contrast, neutrophils are little increased in airway and lung parenchyma tissue sections, which may reflect their rapid transit through these parts of the lung. As neutrophils have both a strong potential to produce oxygen radicals and to secrete several proteinases, including neutrophil elastase (NE), cathepsins, and matrix metalloproteinases (MMPs) ${ }^{34-35}$, they may significantly contribute to parenchymal destruction and chronic mucus hypersecretion.

Increased numbers of macrophages are present in the large and small airways and lung parenchyma of COPD patients, as observed by histopathology, in BAL fluid, bronchial biopsies, and induced sputum studies ${ }^{26-29,37-39}$. Macrophages are long-lived cells derived from peripheral blood monocytes, and are 5 to 10 times more numerous than other inflammatory cells. Macrophages are thought to play a critical orchestrating role in both the persistence of the chronic inflammatory response and the proteolytic matrix degradation in COPD. Activated macrophages release for example neutrophil-chemotactic factors, such as TNF- $\alpha$, leukotriene $B_{4}$ and interleukin-8, hereby promoting neutrophil recruitment ${ }^{5}$. In addition, macrophages secrete a spectrum of potent proteolytic enzymes, including MMP1. MMP-9, and MMP-12, that break down connective tissue in the lung parenchyma and stimulate mucus secretion ${ }^{36}$.

Other inflammatory cell types noted in the lung of COPD patients include $T$ lymphocytes, predominantly CD8+ (cytotoxic) $\mathrm{T}$ cells, and eosinophils. Histopathology and bronchial biopsy studies show an increase in cytotoxic T cells throughout the whole lung ${ }^{25,29,40-42}$. Although their role in COPD inflammation is not yet understood, cytotoxic T-cells may be involved in the apoptosis and destruction of alveolar-wall epithelial cells through the release of perforin, granzyme $B$, and TNF $\alpha^{5}$. The reports on the presence and role of eosinophils in COPD are contradictionary. However, most studies agree that airway eosinophils are not prominent in COPD except during acute exacerbations or in patients with concomitant asthma.

Next to inflammatory cells, resident cells within the lung are likely to contribute to inflammation in COPD. The epithelium is a target for factors released by infiltrating inflammatory cells and serves as a major effector of inflammation ${ }^{4.3}$. On encountering such agents, airway and alveolar epithelial cells can produce a spectrum of proinflammatory mediators, including cytokines, chemokines, acute-phase proteins, lipid mediators, and reactive nitrogen and oxygen species, which can further effect pathophysiological alterations like mucus hypersecretion and influx of inflammatory cells ${ }^{44}$. The endothelium plays also a significant role in inflammatory processes. In COPD, pulmonary endothelium 
demonstrated increased expression of adhesion molecules like E-selectin and ICAM-1, which serve as anchors for circulating inflammatory cellis to transmigrate into the lung tissue ${ }^{45,45}$. To date, the actual role of epithelial cells and endothelial cells in the chronic inflammation in COPD has not been thoroughly studied.

\section{Inflammatory mediators}

Migration and activation of inflammatory cells is regulated by cytokines and chemokines secreted by a variety of structural cells, such as epithelial, endothelial, smooth muscle, and fibroblasts, as well as by activated inflammatory cells. In COPD, increased levels of cytokines (TNF- $\alpha$ ) and chemokines (IL-8, LTB ${ }_{4}, M C P-1$, MIP-1B, GRO- $\alpha$ ) have been demonstrated in induced sputum and/or BAL fluid as compared to control subjects ${ }^{28,47-49}$. In addition, elevated expression of IL-8, MIP$1 \alpha$, MCP-1, IP-10 and TGF- $\beta$ and/or their mRNA has been observed in bronchiolar epithelium, and of the chemokine receptor CCR-2 in macrophages from smokers with COPD compared with those without COPD ${ }^{31,50-53}$. Yet limited information is available concerning the specific role of these inflammatory mediators involved in the pathogenesis of COPD.

\section{Proteinase-antiproteinase imbalance}

Neutrophils and macrophages can potentially produce large quantities of proteinases that play a significant role in restoring tissue homeostasis after inflammatory processes. In COPD, an imbalance of proteinases and antiproteinases is thought to contribute to destruction and remodelling of the extracellular matrix $(\mathrm{ECM})$, the critical contributor to the integrity of the lung, resulting in loss of recoil and eventually emphysema. This imbalance may involve increased production or activity of proteinases, or inactivity or reduced production of antiproteinases, or both. However, the cell types and proteinases responsible for ECM destruction and the ECM components that are targets of the proteinases have not yet been identified ${ }^{54}$. Concerning the proteinases involved, the attention has been primarily focussed on neutrophil elastase based on the increased prevalence of emphysema in patients with congenital deficiency of $\alpha_{1}-A T$, an endogenous inhibitor of neutrophil elastase ${ }^{3}$. However, a large majority of patients with $\alpha_{1}$-AT deficiency do not develop emphysema and success of clinical trials with $\alpha_{1}$-AT supplementation therapy in both $\alpha_{1}$-AT deficient patients and patients with primary COPD is limited ${ }^{55}$. The $\alpha_{1}-\mathrm{AT} /$ neutrophil elastase concept is further challenged by histological and biochemical studies. First, no apparent association between accumulation of neutrophills and parenchymal destruction was found in COPD patients ${ }^{56}$. Second, structural support of cells in the lung is primarily dependent on interstitial collagens (predominantly collagen type I and III), which are highly resistant to proteolytic degradation, and can only be cleft by specific collagenases ${ }^{57}$. Therefore, additional proteinases may be involved in COPD caused by inhalational exposures, such as cathepsins and matrix metalloproteinases (MMPs). Cathepsins comprise a heterogenous family of lysosomal cysteine proteases with enormous disruptive potentia ${ }^{53}$. Elevated levels of cathepsin $\mathrm{L}$ and $\mathrm{G}$ have been demonstrated in BAL fluid or sputum sol phase, respectively, of 
patients with $\mathrm{COPD}^{5 \%, 60}$. MMPs comprise a large family of structurally related zinc metallo-endopeptidases with different substrate specificities, collectively able to degrade most, if not all, protein constituents of the extracellular matrix ${ }^{57,61}$. Importantly, MMPs are secreted in latent form and activated by removal of the amino-terminal propeptide-sequence. The net MMP activity in vivo is therefore dependent on the balance between activated MMP pro-enzymes and the natural Tissue Inhibitors of MetalloProteinases (TIMPs) ${ }^{57.61}$. Recent studies in man support that members of the MMP family are critically involved in the development and progression of emphysema. Increased concentrations of MMPs were found in induced sputum (MMP-9) and BAL fluid (MMP-2, MMP-8, and MMP-9) of COPD patients ${ }^{33,62,63}$. In addition, increased levels of TIMP-1 were measured in COPD patients versus non-smokers ${ }^{62,64}$. In emphysematous lung tissue, increased levels of both protein and mRNA for MMP-1, MMP-2, MMP-8 en MMP-9 were demonstrated ${ }^{63,65,6,66}$. However, studies investigating MMP activity levels are limited and a causal relationship between MMP activity and tissue destruction has not yet been demonstrated.

\section{Oxidative stress}

Oxidant/antioxidant imbalance, in favor of oxidants, is another important feature in COPD. Markers of oxidative stress have been found in the epithelial lining fluid, breath, and urine of patients with COPD. For example, hydrogen peroxide $\left(\mathrm{H}_{2} \mathrm{O}_{2}\right)$ and nitric oxide $(\mathrm{NO})$, which are direct measures of oxidants generated by cigarette smoking or released from inflammatory leukocytes and epithelial cells, are increased in the breath during exacerbations of COPD ${ }^{67,68}$. Oxidative stress may contribute to COPD in numerous ways ${ }^{69}$. First, oxidants can react with, and damage, a variety of biological molecules (proteins, lipids, nucleic acids), leading to cell dysfunction or death, as well as damage to the lung extracellular matrix. Second, oxidative stress contributes to the proteinase-antiproteinase imbalance both by inactivating antiproteinases (such as $\alpha_{1}$-antirypsin and SLPI) and by activating proteinases (such as MMPs). Third, oxidants promote inflammation, for example by activating the transcription factor NF-KB that orchestrates the expression of multiple inflammatory genes like IL-8 and TNF- $\alpha$ thought to be important in COPD. Finally, oxidative stress may contribute to reversible airway narrowing.

\subsection{Pathology}

Pathological changes characteristic of COPD are found in the central airways, peripheral airways, lung parenchyma, and pulmonary vasculature ${ }^{4}$.

\section{Central airways}

The chronic inflammation in the central airways (trachea, bronchi, and bronchioles $>2-4 \mathrm{~mm}$ ) of patients with chronic bronchitis is associated with an increase in the number (metaplasia) of epithelial goblet and squamous cells and mucus hypersecretion ${ }^{1,69}$. In addition, association with dysfunction, damage, and/or loss of cilia; enlarged submucosal mucus-secreting glands; an increase in the amount 
of smooth muscle and connective tissue in the airway wall; degeneration of the airway cartilage was found. The various pathological changes in the central airways are responsible for the symptoms of chronic cough and sputum production, which identify people at risk for COPD and may continue to be present throughout the course of the disease.

\section{Peripheral airways}

The early decline in lung function in COPD is correlated to the pathologic changes in the peripheral airways (small bronchi and bronchioles $<2 \mathrm{~mm}$ ), which include exudate of fluid and cells in the airway wall and lumen, goblet and squamous cell metaplasia of the epithelium, edema of the airway mucosa due to inflammation, and excess mucus in the airways due to goblet cell metaplasia ${ }^{69}$. The most characteristic change in the periperal airways of COPD patients, however, is airway narrowing due to disordered remodeling of the airway wall, which is a result of repeated injury and repair processes initiated by cigarette smoking ${ }^{70}$ and other risk factors. The airway remodelling is characterized by increased collagen deposition and scar tissue formation, and results in significant narrowing of the lumen and fixed airways obstruction ${ }^{71}$. Direct measurements of peripheral airway resistance have shown that the structural changes in the airway wall are the most important cause of the increase in peripheral airways resistance in $\mathrm{COPD}^{72}$.

\section{Lung parenchyma}

The pathologic hallmark of COPD, especially emphysema, is destruction of the lung parenchyma (respiratory bronchioles, alveoli, and pulmonary capillaries). The most common type of parenchymal destruction, defined as non-uniformity in the pattern of respiratory airspace enlargement, in COPD patients is the centrilobular form of emphysema, which involves dilatation and destruction of the respiratory bronchioles, and in advanced disease also of the pulmonary capillary bed ${ }^{4}$. Panacinar (panlobular) emphysema, which extends throughout the acinus ${ }^{1}$, is the characteristic lesion seen in $\alpha_{1}$-AT deficiency and involves dilatation and destruction of the alveolar ducts and sacs as well as of the respiratory bronchioles.

\section{Pulmonary vasculature}

Pulmonary vascular changes in COPD are characterized by a thickening of the vessel wall that begins early in the natural history of the disease, when lung function is reasonably well maintained ${ }^{4}$. Thickening of the intima is the first structural change ${ }^{73}$, followed by an increase in vascular smooth muscle and the infiltration of the vessel wall by macrophages and CD8+T lymphocytes ${ }^{41}$. These structural changes are correlated with an increase in pulmonary vascular pressure that develops first with exercise and then at rest. In addition to thickening of the vessel wall, endothelial dysfunction of the pulmonary arteries, which may be caused directly by cigarette smoke products ${ }^{7 / 4}$ or indirectly by inflammatory mediators ${ }^{47}$, is another early event in the pathology of COPD ${ }^{75}$. Interestingly, recent studies demonstrated decreased expression of VEGF and its receptor (VEGF-2) in emphysematous lung tissue, which was related to increased apoptosis 
of alveolar septal cells, both pneumocytes and endothelial cells ${ }^{76}$.

\subsection{Pathophysiology}

The pathological changes in COPD lead to corresponding physiological abnormalities that usually become evident first on exercise and later also at rest. Expiratory airflow limitation is the physiological hallmark of COPD. Table 1 shows the pathological causes that contribute to airflow limitation in $\mathrm{COPD}^{69}$. The airflow limitation characteristic of COPD is usually persistent and typically shows a more rapid progressive deterioration with age than is normal. Other physiological changes in COPD include mucus hypersecretion, ciliary dysfunction, pulmonary hyperinflation, gas exchange abnormalities, pulmonary hypertension, and cor pulmonale, and they usually develop in this order over the course of the disease ${ }^{4}$. In turn, the various physiological abnormalities contribute to the characteristic clinical symptoms of COPD, i.e. chronic cough, sputum production and dyspnea ${ }^{69}$.

Table 1. Pathological causes of expiratory airflow limitation in COPD

\begin{tabular}{|c|c|}
\hline Itreversible & Rewersible \\
\hline $\begin{array}{l}\text { - Fibrosis and marrowing of anways } \\
\text { - Doss of etastic recoil due to alweolar destruction } \\
\text { Destruction of alweolar suppork that mathtain } \\
\text { patency of small airways }\end{array}$ & $\begin{array}{l}\text { - Accumulation of inflammatory cells in the lung } \\
\text { Accumulation of mucus and plasma exudate in } \\
\text { bronchi } \\
\text { Sinooth muscle contraction in central and } \\
\text { peripheral airways }\end{array}$ \\
\hline
\end{tabular}

Adapted from GOLD guidelines ${ }^{69}$.

\subsection{Systemic effects}

There is increasing evidence of systemic (i.e. extrapulmonary) effects in patients with COPD, namely systemic inflammation and skeletal muscle dysfunction, which have important negative influence on the quality of life $\mathrm{f}^{77-80}$. Similarly to the observation in the airways, increased amounts of activated PMN, as demonstrated by enhanced expression of the adhesion molecule CD11b/CD18, were demonstrated in the circulation of COPD patients in a clinical stable condition ${ }^{81}$. In line herewith, proof for systemic oxidative stress in smokers and COPD patients was obtained by the observation of a reduction of the total antioxidative capacity, paralleled by enhanced levels of lipid peroxidation products, as indices of overall oxidative stress ${ }^{82}$. Besides activation of PMN, also activation status of circulating lymphocytes has been demonstrated indicated by enhanced expression of cytochrome oxidase ${ }^{* / 3}$. Several studies investigating inflammatory mediators in COPD demonstrated enhanced circulating concentrations of acute-phase proteins, such as C-reactive protein (CRP), lipopolysaccharide (LPS) binding protein (LBP) and fibrinogen, along with acute-phase cytokines like IL-6 and TNF- $\alpha^{77,78,84-87}$. In addition, small but significant increases in plasma levels of soluble receptors for TNF (STNF-R55 and STNF-R75) were noted, which are considered to be markers of a pro-inflammatory state because of their shedding from the cell membrane in 
response to endogenous $\mathrm{TNF}-\alpha$ and other inflammatory mediators.

In addition to systemic inflammation and oxidative stress $s_{t}$ profound weight loss is noted in some COPD patients, particularly those with predominant emphysema ${ }^{88}$. The weight loss, particularly depletion of fat free mass, is due to disturbances in energy balance. Leptin is known to regulate the energy balance via a feedback mechanism in which the hypothalamus is involved ${ }^{89}$. Leptin is a hormone produced by the adipose tissue, and circulating leptin levels are proportional to the amount of fat mass ${ }^{90}$. In stable depleted emphysematous patients with COPD, plasma levels of leptin were inversely related to dietary intake as well as to weight gain after nutritional therapy $y^{91}$. In addition, circulating leptin was found to be positively related to plasma soluble TNF-receptor 55 in stable patients with emphysema ${ }^{91}$. In addition to disturbances in energy balance, skeletal muscle dysfunction characterized by the progressive loss of skeletal muscle mass as well as fiber-type redistribution contributes to weight loss in $\mathrm{COPD}^{92}$. In addition to airflow limitation and loss of alveolar structure, skeletal muscle wasting was demonstrated to play an important role in dyspnea and exercise limitation in $\mathrm{COPD}^{93}$, and thus the decline of health status.

\subsection{Treatment}

Despite the burden of COPD, treatment of COPD is primarily symptomatic, essentially bronchodilators, and often unsatisfactory with no drugs currently available that halt the progressive course of airflow limitation in COPD patients ${ }^{4}$. The regular use of glucocorticosteroids is disappointing, as important elements of the inflammatory response were demonstrated to be insensitive after short-term treatment with inhaled steroids ${ }^{94,95}$. In addition, long-term therapy resulted in an improvement in $\mathrm{FEV}_{1}$ in the first months of treatment, but the rate of decline in $\mathrm{FEV}_{1}$ was not retarded after that period ${ }^{96-99}$. To date, identification, reduction, and control of risk factors (tobacco smoke, occupational exposures, air pollution, and irritants) is the single and most (cost) effective way toward prevention and treatment of COPD $^{4}$. Since cigarette smoking is the major risk for COPD worldwide, smoking prevention programs are being implemented and smoking cessation programs will be readily available en encouraged for individuals who smoke. Quitting smoking can prevent or delay the development of airflow limitation or reduce the age-related decline in $\mathrm{FEV}_{1}{ }^{13,100,100}$. However, a longitudinal follow-up study of smoking-induced lung density changes by highresolution computed tomography demonstrated that the worsening airspace abnormality in the upper lung zones of smokers did not slow down with cessation of smoking ${ }^{t 02}$. In addition, other studies investigating airway inflammation reported that smoking cessation did not result in resolution of the inflammatory response in the airways ${ }^{45,103-106}$. These observations suggest that there are perpetuating mechanisms that maintain the chronic inflammatory process once it has become established, and such mechanisms may account for the presentation of COPD in patients who have stopped smoking many years before their first symptoms develop. Thus, there is a great need to develop new and effective therapeutic interventions for COPD. 


\subsection{Summary}

COPD is a complex heterogeneous respiratory disease that includes three different disease conditions (chronic bronchitis, small airway disease, and emphysema) and represents a major and growing health care problem. Risk factors for development of COPD include both host factors and environmental exposures, and cigarette smoking is widely recognized as the most important risk factor in industrialized countries. There is increasing evidence that COPD is associated with a chronic inflammatory response throughout the airways, lung parenchyma, and pulmonary vasculature, although the types of inflammatory cells may vary in the different compartments of the lung. Cellular inflammatory infiltrates and production of inflammatory mediators, proteinases, and reactive nitrogen and oxygen species are all thought to contribute to the pathologic changes characteristic for COPD. Furthermore, there is increasing evidence of systemic (i.e. extrapulmonary) effects in patients with $\mathrm{COPD}_{r}$ namely systemic inflammation, oxidative stress, and skeletal muscle dysfunction, which have important negative influence on the quality of life. Despite the burden of COPD, there are only limited therapeutic strategies available for treatment of COPD, and development of novel therapies is hampered by absence of suitable animal models of COPD for pre-clinical drug testing.

\section{COPD MODELING}

Until a few years ago, there has been little interest in investigating the molecular and cell biology of COPD. The largely physiological definition of COPD has certainly contributed to this lack of knowledge. We have yet to understand many crucial issues involved in COPD, such as mechanisms of airflow obstruction, inflammatory cell recruitment, persistence of chronic inflammation, and abnormal repair, before new therapeutic targets can be identified. In addition, it is still unclear why only $10-20 \%$ of cigarette smokers will eventually develop clinically significant COPD.

As there are major similarities in lung development and lung structure between humans and other mammals, animal models are critical experimental tools to study the pathophysiology of COPD. The ultimate goal is then to translate information gained from the development of animal models to prevention as well as treatment strategies. In the past decades, different models in rodents (rat, mouse, hamster, guinea pig, rabbit) and sheep have been developed to study COPD, each with its specific characteristics, as discussed below. Furthermore, a COPD-like disorder is known to exist in horses ${ }^{107}$. It is, however, appropriate to note that the definition of emphysema in experimental animal models is only pathological without physiological descriptions ${ }^{108}$. In the last decade, especially mice are widely used in experimental models. Advantages of the mouse over other experimental animals include the capacity to manipulate germline transmission of genetic information, a rapid reproductive cycle, and large litter sizes. In 
addition, there is large knowledge of mouse biology; antibody and CDNA probes for the mouse are abundant, and mice are relatively cheap compared to other experimental animals ${ }^{109}$. However, to date there are no satisfactory animal models mimicking both chronic inflammation and pathologic changes in COPD that are suitable for early drug testing.

\subsection{Elastase-induced emphysema}

Thirty-five years ago Gross demonstrated that instillation of papain into experimental animals resulted in profound emphysema ${ }^{\text {t10 }}$. Since Gross ${ }^{4}$ initial experiments, investigators have instilled a variety of elastolytic enzymes, including pancreatic elastase ${ }^{111}$, neutrophil elastase ${ }^{12,113}$, and proteinase- $3^{174}$, into the lungs of many small and large animals, resulting in panacinar emphysema. In contrast, instillation of non-elastolytic enzymes, such as bacterial collagenase, did not cause emphysema ${ }^{115}$. Disadvantages of these models, however, are that alveolar destruction by elastolytic enzymes occurs generally in absence of cellular inflammatory infiltrates in the lung. In addition, identification of proteinases and events upstream of proteinase release involved in cigarette smoke-induced emphysema is impossible. Nevertheless, the elastase model remained in use because of its relative simplicity and the fact that it allowed for first-order approximation for study of downstream events, particularly alveolar repair. For example, elastase instillation has been used to demonstrate that retinoic acid has the capacity to promote alveolarization and lung repair in adult rats ${ }^{116}$.

\subsection{Cigarette smoke-related COPD}

A variety of experimental animals have been exposed to cigarette smoke over the years using various protocols. Pathologic changes similar to those observed in COPD patients have been found in cigarette smoke-exposed mice, including lowgrade chronic inflammation and destruction of alveolar structures ${ }^{117}$. On the other hand, mice do not cough up sputum after smoking, probably due to subtle differences in airway structure between man and mice ${ }^{115}$. If these pathologic changes are associated with abnormal pulmonary function or gas-exchange abnormalities, is still unknown and awaits further study. A disadvantage of cigarette-smoke exposure studies is the time needed to produce lesions, up to 12 month in some species. In addition, cigarette smoke is a complex mixture of over 4000 different chemical compounds, including free radicals and oxidants, which makes it difficult to unravel exact mechanisms of cigarette smoke-induced inflammatory processes. However, the cigarette-smoke model is popular, because smoking is the major risk factor to develop COPD. In addition, cigarette smokerelated changes have been demonstrated to be strain-dependent in mice ${ }^{118}$. This provides a unique opportunity to uncover genes involved in susceptibility to COPD.

\subsection{Chemical-induced emphysema}

A variety of chemicals and irritants have been used in experimental animals to generate COPD. Cadmium chloride is extensively used to generate 
emphysematous lesions, which was found to be secondary to fibrotic processes $^{119}$. In addition, experimental models exploring oxidants like nitrogen dioxide and ozone show that these components cause airway changes, such as epithelial cell injury and cilia loss, and mild focal emphysema ${ }^{120}$. Furthermore, exposure studies to inorganic dusts like silica and coal dust demonstrated focal emphysema without changes in airway structures, associated with complex inflammation (neutrophilia) and oxidant injury with connective tissue breakdown ${ }^{121}$. Finally, lipopolysaccharide (LPS) of Gram-negative bacteria is used in experimental animals to generate COPD-like pathology. This will be discussed below (\$3.2).

\subsection{Cenetic models of airspace enlargement \\ Natural mutations}

Several spontaneous mutant mouse strains develop airspace enlargement. These are usually developmental abnormalities rather than destruction of mature lung tissue characterizing emphysema. Tight skin $(T s k+/-)$ mice have a mutation in fibrillin-l, which is involved in elastic fiber assembly ${ }^{122}$. These mice have abnormal air-space development and progressive alveolar enlargement with age. Pallid mice (pa/pa) develop mild emphysema late in life ${ }^{123}$, but the cause for this is unknown. Blotchy mice have enlarged air spaces believed to be a result of abnormal connective tissue or cross-linking ${ }^{124}$. More recently, this mutation has been localized to abnormal RNA processing of the Menke gene on the $X$ chromosome mottled locus ${ }^{124}$, but the relationship with emphysema remains unknown. Beige mice (bg) have a defect in formation of primary granules ${ }^{125,126}$. It remains controversial whether they produce normal levels of serine proteinases and have the capacity to develop emphysema.

\section{Transgenic mice}

Just over one decade ago, techniques to achieve germline transmission of genetic material in mice (transgenic technology) drastically changed the approach to biological questions, and can be used to address questions of function of individual mediators. Introduction of a linear DNA fragment (transgene) into the pronucleus of embryos or embryonic stem cells allows study of either the pattern of expression of that gene, or the biological consequences of overexpression of the protein encoded by the gene in specific tissues (gain of
function/overexpression model) ${ }^{109}$. More recently, targeted mutagenesis by
homologous recombination in embron homologous recombination in embryonic stem cells has allowed investigators to generate strains of mice that lack individual proteins, providing specific loss of
function models (loss of function/knock-out model) ${ }^{109}$.

Several transgenic mice overexpressing mediators involved in inflammatory processes were shown to develop emphysematous changes. For example, mice
overexpressing collagenase-1 (MMP-1) show enlarged air spaces ${ }^{127}$, but it is
unclear whether this is because of the destrution unclear whether this is because of the destruction of collagen or interference with lung growth and development. In addition, lungs of transgenic mice overexpressing specific proinflammatory cytokines - inducible or not - in alveolar 
type II cells (TNF- $\alpha^{128}$ ) or airway epithelial cells (IFN- $\gamma,\|L-6\| L-$,11 , or $\| \mathrm{L}-13^{129-131}$ ) display enormous alveolar destruction, accompanied by profound ongoing inflammation in airways and lung parenchyma, the pattern of which is cytokinedependent. In case of $1 \mathrm{~L}-13$, the increase in lung size, alveolar size, lung compliance, and pulmonary inflammation was shown to dependent on the chemokine receptor CCR2, whereas mucus cell metaplasia was not ${ }^{132}$.

Knock-out strains generated by targeted mutagenesis pointed at the important role of growth factors in alveolar septation. For example, lungs of FGFR-3/FGFR-4 double knock-out mice (deficient in both fibroblast growth factor receptors 3 and 4) are normal at birth but then fail to undergo alveogenesis ${ }^{133}$. In addition, gradual appearance of emphysema with age has been described in surfactant protein D (SP-D) knock-out mice ${ }^{134}$ and in mice lacking TIMP- $3^{135}$. In both cases, MMPs were implicated as mediators of tissue destruction. Furthermore, the klotho mouse (generated due to a failed transgenic experiment to develop a model of hypertension) displays features of premature aging, including a short lifespan, infertility, arteriosclerosis, skin atrophy, osteoporosis, and "emphysema" " $^{\text {nis }}$. It is, however, not yet clear whether klotho mice have abnormal development or truly premature aging resulting in emphysematous changes.

The combination of gene targeting with exposure models provides a unique opportunity to perform highly controlled experiments that differ with respect to expression of a single protein in mammals. In that way, strains of mice deficient in individual candidate genes can be compared to determine their contribution to the development of emphysema in response to cigarette smoke. For example, exposure of macrophage elastase (MMP-12) knock-out mice and wild-type littermates to chronic cigarette smoke exposure demonstrated that in contrast with wild-type mice, MMP-12 knock-out mice did not develop emphysema ${ }^{117}$. In addition, MMP-12 knock-out mice also failed to recruit macrophages into their lungs in response to cigarette smoke, hereby suggesting that the macrophage and its matrix metalloproteinases may be important in emphysematous changes, at least in mice.

\subsection{Summary}

Emphysema can be modelled in many ways. Exogenous administration of proteinases, chemicals, particulates, and exposure to cigarette smoke was demonstrated to result in features characteristic of human emphysema. In addition, airspace enlargement during development and throughout life was demonstrated in genetic manipulated mice (both gain and loss of function models). The use of animal models is crucial to address the many unsolved issues in COPD, such as mechanisms of airflow obstruction, inflammatory cell recruitment, persistence of chronic inflammation, and abnormal repair. To date, however, no satisfactory animal models mimicking both chronic inflammation and pathologic changes in COPD are available that are suitable for early drug testing. 


\section{LIPOPOLYSACCHARIDE (LPS) AND COPD}

As outlined in $\$ 1.2$, the major environmental factor that predisposes patients to COPD is chronic exposure to cigarette smoke. Recently, high levels of bioactive lipopolysaccharide (LPS) are reported to be present in cigarette smoke ${ }^{137}$. LPS is a major proinflammatory constituent present in the outer cell wall of all Gramnegative bacteria. In addition, previous studies have revealed that LPS is ubiquitously present in high concentrations as contaminant on natural airborne particles, including organic dusts, air pollution, and house dusts ${ }^{138-142}$.

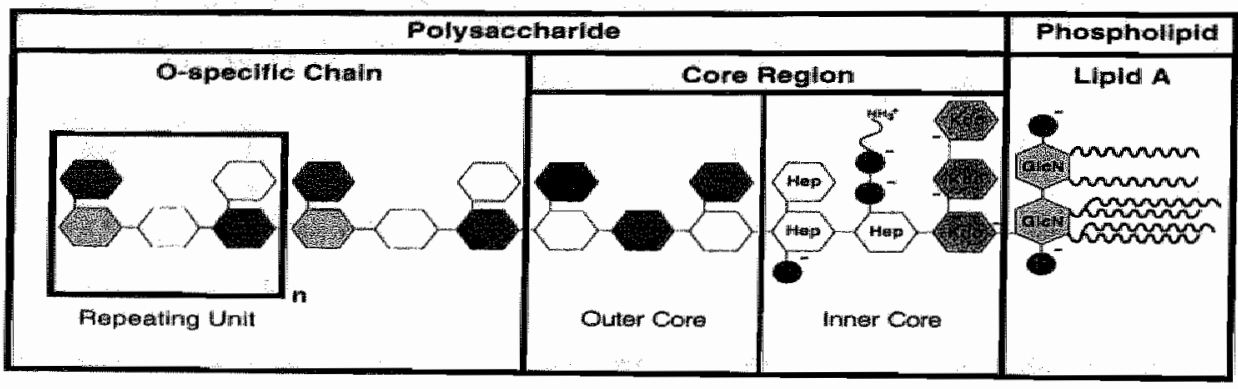

Figure 2. The structure of LPS is composed of a hydrophobic lipophilic region (lipid A) and a covalently linked hydrophilic polysaccharide part consisting of an O-specific chain and a core region ${ }^{143}$.

\subsection{Structure and signal-transduction pathway of LPS}

LPS is an extremely heat-stable amphiphilic molecule composed of a hydrophobic lipophilic region (lipid A) and a covalently linked hydrophilic poly- or oligosaccharide portion (Figure 2) ) $^{143}$. The lipid A part, which is highly conserved among LPS of different bacteria, is responsible for most of the biological effects of LPS due to the specific and often highly sensitive recognition of lipid $A$ by numerous cellular and humoral components of innate immunity. Since LPS is present in all Gram-negative bacteria, the host recognition of and response to this glycolipid provides protection against a wide range of microorganisms ${ }^{143}$.

The primary target cells of LPS in mammalian species are the professional phagocytes of the innate immunity system (ie peripheral macrophages, tissue macrophages, and neutrophils). Extensive studies on the molecular mechanisms of LPS recognition and signaling have elucidated that phagocyte activation by extracellularly supplied LPS or lipid A is initialized by the combined actions of LPS binding protein (LBP), the membrane forms of CD14 (mCD14), and the recently identified Toll-like receptor (TLR)-4* MD2 complex on the cellular surface (Figure 3). As a result, rapid and coordinated activation of various intracellular signaling pathways including activation of the major MAP kinase cascades and translocation of NF- $\mathrm{KB}$ will lead to the secretion of a wide spectrum of endogenous mediators, such as pro-inflammatory cytokines, chemokines, lipid-derived mediators, and reactive oxygen species ${ }^{143}$. By means of the soluble form of CD14 antigen (sCD14), LPS may also activate constitutively CD14 negative cells such as 
dendritic cells, vascular endothelial and smooth muscle cells as well as epithelial cells and fibroblasts, most of which, in case of human origin, have been demonstrated to express TLR-4. Recently, Nod1 and Nod2 were discovered as independent cytosolic counterparts of TLRs, acting in activation of $N F-K B$ via binding of intracellular LPS ${ }^{144}$. The endogenous mediators released during this early phase of LPS-induced activation of innate immunity initiate a complex network of secondary reactions. These include the activation of the complement system (both classical and lectin pathways), the stimulation of acute-phase protein secretion by hepatocytes, the activation of lymphocytes, platelets, basophils, mast cells, and eosinophils, an elevated hematopoietic activity of the bone marrow, an increased systemic procoagulant state, and activation of the neuro-endocrine system $^{145}$.

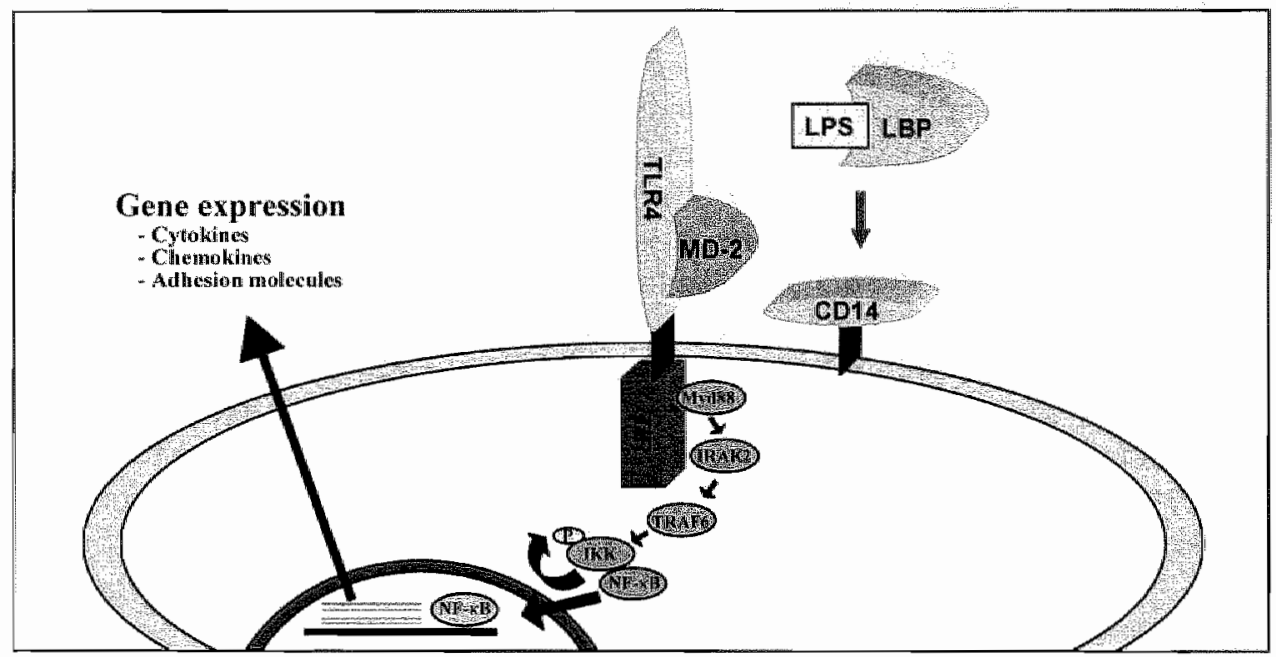

Figure 3. LBP/CDH 4TLR4/MD2 signal transduction pathway of LPS results in translocation of NF the nucleus and subsequent gene expression of cytokines, chemokines, and adhesion molecules.

\subsection{LPS exposure studies}

\section{Human studies}

In ambient breathing air, LPS is measured at very low concentrations $( \pm 0.4$ $\left.\mathrm{ng} / \mathrm{m}^{3}\right)^{146}$. Under these conditions, the lung has efficient defense mechanisms against airborne LPS, including 1) the physical removal by the mucociliary system and cough; 2) the presence of broad-spectrum anti-microbial agents in the epithelial lining fluid; 3) the activation of resident alveolar macrophages; and 4) the epithelial barrier itself ${ }^{23}$.

Exposure to significant levels of LPS, however, is associated with the development and/or progression of chronic lung diseases. Epidemiological studies have shown that the concentration of inhaled LPS in the bioaerosol was strongly associated with airflow obstruction in cotton workers ${ }^{147}$, agricultural workers ${ }^{1493}$, and fiberglass workers ${ }^{149}$. In fact, the concentration of LPS in the bioaerosol was found to be the most important occupational exposure associated with the 
development ${ }^{19}$ and progression ${ }^{14 t}$ of chronic airway disease in agricultural workers. Moreover, healthy study subjects challenged with dust from animal confinement buildings developed airflow obstruction and an increase in the serum concentration of neutrophils and IL-6, all of which were strongly associated with the concentration of endotoxin (not dust) in the bioaerosol ${ }^{50}$.

Experimentally, inhalation of LPS induces dose-related clinical symptoms, such as fever and fatigue, reversible aiffow obstruction and activation of the innate immune system in previously unexposed healthy study subjects ${ }^{151,852}$. Within $4-6$ hours following inhalation of L.PS or organic dusts containing LPS, an influx of neutrophils and lymphocytes was found in BAL fluid with increased levels of inflammatory mediators (TNF- $\alpha, \mathrm{IL}-1 \mathrm{~B}, \mathrm{IL}-6, \mathrm{IL}-8$, and fibronectin) $)^{153-155}$. Circulating levels of TNF- $\alpha$ and CRP were also raised ${ }^{151.1515}$. As in vitro studies have demonstrated that respiratory epithelial cells secrete a variety of inflammatory mediators in response to LPS ${ }^{44,157}$, the respiratory epithelium may be an important source of these mediators in BAL fluid after LPS inhalation in healthy subjects.

There is a considerable inter-individual variability in the sensitivity to LPS by inhalation. Asthmatics ${ }^{158}$ and individuals with chronic bronchitis ${ }^{159}$ respond more sensitive to LPS as they develop airflow obstruction at lower concentrations of inhaled LPS compared to healthy subjects. In addition, the concentration of airborne endotoxin in the domestic setting was reported to be associated with the clinical severity of asthma in a dose-dependent manner ${ }^{142}$ " Recently, cosegregating missense mutations (Asp299Gly and Thr399lle) affecting the extracellular domain of the TLR4 receptor were found to be associated with a blunted response to inhaled LPS in humans. This study demonstrates that genesequence changes can alter the ability of the host to respond to environmental stress $^{160}$.

\section{Animal models}

In view of the potent inflammatory effects of LPS, the role of LPS in lung diseases was further studied in experimental animal models. Resident alveolar macrophages are considered to be the most important effector cells to pulmonary LPS exposure. Activation of alveolar macrophages by a single LPS dose results in an inflammatory cascade defined by regulated expression of a variety of genes in the lung, including early response cytokines (TNF- $\alpha, \quad$ IL-1 $\alpha$, IL-1B, IL-6), chemokines (MIP-1 $\alpha$, MIP-1 $\beta, M I P-2, C I N C)$, and endothelial leukocyte adhesion molecules (ICAM-1, selectins) ${ }^{161-169}$. The transcription of many of these genes is mediated by the NF-KB family of transcription factors, and nuclear translocation of the NK-KB RelA subunit was shown to be critical to inducing the gene expression mediating neutrophil emigration elicited by LPS in the lungs ${ }^{170}$. The increased gene expression consequently results into profound, but transient influx of neutrophils into the interstitium and air spaces ${ }^{171}$. This neutrophilia plays a prominent role in the host defence against pathogens, but is also considered to be responsible for the pulmonary injury, manifested by increased lung vascular permeability, edema and cell death, as neutrophils release histotoxic substances, including proteases and reactive oxygen species ${ }^{172,173}$. In this respect, programmed cell death 
(apoptosis) plays a crucial role in limiting the inflammatory response and clearance of neutrophils from inflamed tissue ${ }^{174_{1}, 75_{4}}$

In addition to alveolar macrophages, airway and alveolar epithelial cells contribute to the innate immune response in response to pulmonary LPS exposure. LPS exposure results in increased production of direct antimicrobial molecules, mucins ${ }^{176}$, and NO by airway epithelium, and surfactant proteins and acute-phase reactants by alveolar epithelium ${ }^{17-180}$. In concert with the upregulation of this antimicrobial defense, LPS exposure initiates an inflammatory response in epithelial cells. In vitro studies demonstrated that primary respiratory epithelial cell cultures as well as cell lines stimulated with LPS produce a variety of chemoattractants, cytokines, and growth factors (reviewed by Fehrenbach ${ }^{\text {isit). }}$ ).

Studies investigating chronic LPS exposure are limited, and primarily focus on pathologic changes. In a series of studies, Stolk and colleagues reported that repeated intratracheal LPS instillation in hamsters resulted in bronchial mucus cell hyperplasia and profound parenchymal destruction. Inhibition of endogenous neutrophil elastase, released by recruited neutrophils as a consequence of the LPS instillations, was shown to reduce the extent of LPS-induced emphysema ${ }^{16:-1866}$. Consistent with the hamster studies, destruction of alveolar structures by repeated pulmonary LPS exposure was shown in guinea pigs ${ }^{187.189}$, rats ${ }^{190}$, and mice ${ }^{191,192}$. In addition, airway wall thickening was noted after long-term exposure to LPScontaminated corn dust extract in LPS-sensitive mice ( $\mathrm{C} 3 \mathrm{H} / \mathrm{HeBFeJ})$, but not in LPS-resistant mice $(\mathrm{C} 3 \mathrm{H} / \mathrm{He}])^{193}$. In contrast to the pathologic changes induced by repeated LPS exposure to the lungs, the chronic inflammatory response is not well defined. A recent study reported peribronchial cellular infiltrates as well as neutrophilic infiltration in airways, parenchyma and vasculature within 1 day after chronic LPS exposure in mice ${ }^{191}$. In view of this LPS-induced neutrophilia, depletion of neutrophils was shown to diminish LPS-induced airway wall thickening ${ }^{192}$.

\subsection{Summary}

The respiratory system is continuously exposed to bacterial L.PS due to inhalation of airborne particles, including cigarette smoke and organic dusts. Experimentally, inhalation of LPS induces dose-related clinical symptoms, such as fever and fatigue, reversible airflow obstruction and activation of the innate immune system. There is a considerable inter-individual variability in the sensitivity to LPS by inhalation, with asthmatics and individuals with chronic bronchitis responding more sensitive than healthy subjects. Futhermore, chronic exposure to significant levels of LPS is known to be associated with the development and/or progression of chronic inflammatory lung diseases.

In this view, the role of LPS in lung diseases was further studied in experimental animal models. Extensive studies have demonstrated that single exposure of LPS to the lung activates alveolar macrophages via LPS binding protein (LBP)/CD14/Toll-like receptor (TLR)-4/MD2 dependent pathway to produce specific cytokines, associated with transient neutrophil influx and vascular permeability. Studies investigating chronic LPS exposure are limited, and primarily 
focus on pathologic changes being bronchial mucus cells hyperplasia and parenchymal destruction.

\section{REFERENCES}

1. ATS. Standards for the diagnosis and care of patients with chronic obstructive pulmonary disease. Am I Respir Crit Care Med 1995; 152:577-121.

2. Siafakas $N M_{i}$ vermeire $P$, Pride $N B_{r}$ Paoleti $P$, Gibson I. Howard $P$, Yernault $J C$, Decramer $M$ Higenbottam T, Postma DS, and et al. Optimal assessment and management of chronic obstructive pulmonary disease (COPD). The European Respiratory Society Task Force. Eur Respir $11995 ; 8: 1398-1420$.

3. Jeffery PK. Remodeling in asthma and chronic obstructive lung disease. Am J Respir Crit Care Med $2001 ; 164: \$ 28-38$.

4. Patwwels RA, Buist AS, Calverley PM, Jenkins CR, and Hurd SS. Global strategy for the diagnosis, management, and prevention of chronic obstructive pulmonary disease. NHLBI/WHO Cilobal Initiative for Chronic Obstructive Lung Disease (GOLD) Workshop summary. Am / Respir Crit Care Med 2001; 163:1256-1276.

5. Barnes PJ. Chronic obstructive pulmonary disease. N Engl/ Med 2000;343:269-280.

6. Van den Boom G, Van Schayck CP, Van Mollen MP, Tirimanna PR, Den Otter J], Van Giunswen $P M, B$ uitendijk MJ, Van Herwarden $\mathrm{CL}$, and Van Weel $\mathrm{C}$. Active detection of chronic obstructive pulmonary disease and asthma in the general population. Results and economic consequences of the DIMCA program. Am J Respir Crit Care Med 1998; 158:1730-1738.

7. Rutten-van Molken MP, Postma MI, Joore MA, Van Genugten ML, Leidl R, and Jager JC. Current and future medical costs of asthma and chronic obstructive pulmonary disease in The Netherlands. Respir Med 1999;93:779-787.

8. Mahadeva R, and Lomas DA. Genetics and respiratory disease. 2. Alpha 1-antitrypsin deficiency, cirrhosis and emphysema. Thorax 1998;53:501-505.

9. Lieberman 1 . Winter $B$, and Sastre A. Alpha 1-antitrypsin Pi-types in 965 COPD patients. Chest $1986 ; 839: 370-373$.

10. Fletcher $\mathrm{C}$, and Peto $\mathrm{R}$. The natural history of chronic airflow obstruction. Br Med / 1977;1:16451648.

11. Barnes PJ. Chronic obstructive pulmonary disease: new opportunities for drug development. Trends Pharmaco/ Sci 11998;19:415-423.

12. Sherrill $\mathrm{DL}_{r}$ Holberg $\mathrm{Cl}$, Enright $\mathrm{PL}$, Lebowitz $\mathrm{MD}$, and Burrows $\mathrm{B}$. Longitudinal analysis of the effects of smoking onset and cessation on pulmonary function. Am / Respir Crit Care Med $1994: 149: 591-597$.

13. Scanlon PD, Connett JE, Waller LA, Altose MD, Bailey WC, and Buist AS. Smoking cessation and lung function in mild-to-moderate chronic obstructive pulmonary disease. The Lung Health Study. Am / Respir Crit Care Med 2000;161:381-390.

14. Anthonisen NR, Connett JE, and Murray RP. Smoking and lung function of Lung Health Study participants after 11 years. Am I Respir Crit Care Med 2002;166:675-679.

15. Anthonisen NR, Connett JE, Enright $\mathrm{PL}_{\mathrm{L}}$ and Manfreda 1. Hospitalizations and mortality in the Lung Health Study. Am / Respir Crit Care Med 2002;166:333-339.

16. Kauffrmann F, Drouet D, Lellouch $\mathrm{J}$, and Brille D. Twelve years spirometric changes among Paris area workers. In I Epideniol 1979;8:201-212.

17. Vogelzang PF, van der Gulden IW, Folgering $\mathrm{H}$, Kolk II, Heederik D, Preller L, Tielen MJ, and van Schayck CP. Endotoxin exposure as a major determinant of lung function decline in pig farmers. An / Respir Crit Care Med 1998:157:15-18.

18. Smid T, Heederik D, Houba $R$, and Quanjer PH. Dust- and endotoxin-related acute lung function changes and work related symploms in workers in the animal feed industry. Am I Ind Med 1994;25:877-888.

19. Schwartz DA, Thorne PS, Yagla SI, Burmeister LF, Olenchock SA, Watt IL, and Quinn TI. The rolle of endotoxin in grain dust-induced lung disease. Am / Respir Crit Care Med 1995; 152:603 -608. 


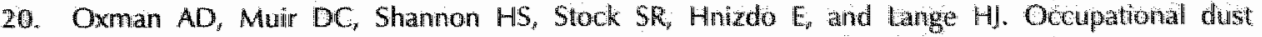
exposure and chronic obstructive pulmonary disease. A systematic overview of the evidence. Am Rev Respir Dis 1993;148:38-48.

21. Sunyer J. Urban air pollution and chronic obstructive pulmonary disease: at review Eur Respor I 2001;17:1024-1033.

22. Buist AS, and Vollmer WM. 1994. Smoking and other risk factors. In J.F. Murray, and I.A. Nadet, editors. Textbook of respiratory medicine, ed. Saunders, W.B., Philadelphia. $1259-1287$.

23. Whitsett JA. Intrinsic and innate defenses in the lung: intersection of pathways regulating lung morphogenesis, host defense, and repair. / Clin Imvest 2002;109:565-569.

24. Finkelstein R, Fraser RS, Ghezzo $H$, and Cosio MG. Alveolar inflammation and its relation to emphysema in smokers. Am J Respir Crit Care Med 1995; 152:1666-1672.

25. Saetta $M$, Di Stefano $A$, Turato $G$, Facchini $F M$, Corbino $L_{i}$ Mapp $C E$, Maestrelli $P$, Ciaccia $A$ and Fabbri LM. CD8 + T-lymphocytes in peripheral airways of smokers with chronic obstructive pulmonary disease. Am J Respir Crit Care Med 1998;157:822-826.

26. Peleman RA, Rytila PH, Kips JC, Joos GF, and Pauwels RA. The cellular composition of induced sputum in chronic obstructive pulmonary disease. Eur Respir / 1999;13:839-843.

27. Pesci A, Balbi B, Majori M, Cacciani $G$, Bertacco S, Alciato P, and Donner CF, Inflanmatory cells and mediators in bronchial lavage of patients with chronic obstructive pulmonary disease. Eur Respir / 1998;12:380-386.

28. Keatings $\mathrm{VM}$, Collins $\mathrm{PD}$, Scott $\mathrm{DM}$, and Barnes PJ. Differences in interleukin-8 and tumor necrosis factor-alpha in induced sputum from patients with chronic obstructive pulmonary disease or asthma. Ann I Respir Crit Care Med 1996;153:530-534.

29. O'Shaughnessy TC, Ansari TW, Barnes NC, and Jeffery PK. Inflammation in bromchial biopsies of subjects with chronic bronchitis: inverse relationship of CD8+ T lymphocytes with FEV1. AnI Respir Crit Care Med 1997;155:852-857.

30. Alexis NE, Hu SC, Zeman $K_{\text {, Alter }}$, and Bennett WD. Induced Sputum Derives from the Central Airways. Confirmation using a radiolabeled aerosol bollus delivery technique. Am / Respir Crit Care Med 2001;164:1964-1970.

31. Di Stefano A, Capelli A, Lusuardi M, Balbo P, Vecchio C, Maestrelli P, Mapp CE, Fabbri LM, Donner $C F$, and Saetta $M$. Severity of airflow limitation is associated with severity of airway inflammation in smokers. Am / Respir Crit Care Med 1998;158:1277-1285.

32. Keatings VM, and Barnes PI. Granulocyte activation markers in induced sputum: comparison between chronic obstructive pulmonary disease, asthma, and normal subjects. Am / Respir Crit Care Med 1997;155:449-453.

33. Betsuyaku T, Nishimura $M$, Takeyabu $K$, Tanino $M$, Venge P, Xu S, and Kawalkami $Y$. Neutrophil granule proteins in bronchoalveolar lavage fluid from subjects with subclinical emphysema. Am J Respir Crit Care Med 1999:159:1985-1991.

34. Stockley RA. Neutrophils and the pathogenesis of COPD. Chest 2002;121:151S-155S.

35. Pettersen CA, and Adler KB. Airways inflammation and COPD: epithelial-neutrophil interactions. Chest 2002;121:142S-150S.

36. Woessner JF. 1998. The Matrix Metalloproteinase Family. Academic Press, San Diego.

37. Peinado $V$, Barbera $J A$, Abate $P$, Ramirez I, Roca I, Santos $S$, and Rodriguez-Roisin R. Inflammatory reaction in pulmonary muscular arteries of patients with mild chronic obstructive pulmonary disease. Aum / Respir Crit Care Med 1999;159:1605-1611.

38. Lacoste $J Y$, Bousquet J, Chanez $\mathbb{P}$, Van Vywe $T$, Simony-Lafontaine J, Lequeu $N$, Vic P, Enander $\|_{\text {, }}$ Godard $P$, and Michel FB. Eosinophilic and neutrophilic inflammation in asthma, chronic bronchitis, and chronic obstructive pulmonary disease. J Allergy Clin Immunol 1993; 92:537-548.

39. Pesci A, Majori $M$, Cuomo A, Borciani $N$, Bertacco S, Cacciani $G$, and Gabrielli M. Neutrophils infiltrating bronchial epithelium in chronic obstructive pulmonary disease. Respir Med 1998;92:863-870.

40. Saetta $M$, Baraldo $S$, Corbino $L$, Turato $G$, Braccioni $F$, Rea F, Cavallesco $G$, Tropeano $G$, Mapp $C E$, Maestrelli $P$, Ciaccia $A$, and Fabbri $L M$. CD8+ve cells in the lungss of smokers with chronic obstructive pulmonary disease. Am / Respir Crit Care Med 1999;160:711-717.

41. Peinado VI, Barbera $J A_{*}$ Abate $P$, Ramirez J, Roca J, Santos $S$, and Rodriguez Roisin $R$. Inflammatory reaction in pulmonary muscular arteries of patients with mild chronic obstructive pulmonary disease. Am / Respir Crit Care Med 1999;159:1605-1611. 


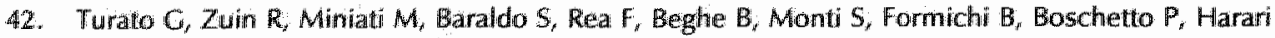
5 , Papi $A$, Maestrelli $P$, Fabbri $L M$, and Saetta M. Airway inflammation in severe chronic obstructive pulmonary disease: relationship with lung function and radiologic emphysema. Am J Respir Crit Care Med 2002;166:105-110.

43. Takizawa H. Airway epithelial cells as regulators of airway inflammation. Int / Mol Med $1998,91: 367-378$.

44. Diamond $\mathrm{G}$, Legarda $\mathrm{D}$, and Ryan LK. The innate immune response of the respiratory epithelium. Immuniol Rev 2000; 173:27-38.

45. Turato $G$, Di Stefano $A_{r}$ Maestrelli $P$, Mapp $C E$, Ruggieri MP, Roggeri $A_{c}$ Fabbri $L M$, and Saetta $M$. Effect of smoking cessation an airway inflammation in chronic bronchitis. Am / Respir Crit Care Med 1995;152:1262-1267.

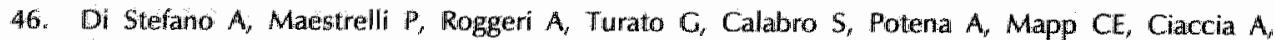
Covacev $L$, Fabbri $L M$; and at al. Upregulation of adhesion molecules in the bronchilal mucosa of subjects with chronic obstructive bronchitis. Am J Respir Crit Care Med 1994;149:803-810.

47. Traves SL, Culpitt SV, Russell RE, Barnes PJ, and Donnelly LE. Increased levels of the chemokines GROalpha and MCP-1 in sputum samples from patients with COPD. Thorax 2002;57:590-595.

48. Capelli $A$, Di Stefano $A$, Gnemmi I, Babo $P$, Cerutti $C C_{r}$ Balbi $B$, Lusuardi $M$, and Donner $C F$. Increased MCP-1 and MIP-1beta in bronchoalveolar lavage fluid of chronic bronchitics. Eur Respir 1 1999;14:160-165.

49. Hill AT, Bayley D, and Stockley RA. The interrelationship of sputum inflammatory markers in patients with chronic bronchitis. Am / Respir Crit Care Med 1999; 160:893-898.

50. De Boer WI, Sont $\mathbb{K} K$, Van Schadewijk A, Stolk 1 , Van Krieken $\mathrm{JH}$, and Hiemstra PS. Monocyte chemoattractant protein 1 , interleukin 8 , and chronic airways inflammation in COPD. J Pathol 2000;190:619-626.

51. De Boer WI, van Schadewijk A, Sont JK, Sharma HS, Stolk J, Hiemstra PS, and Van Krieken JH. Transforming growth factor betat and recruitment of macrophages and mast cells in airways in chronic obstructive pulmonary disiease. Am J Respir Crit Care Med 1998;158:1951-1957.

52. Vignolla $A M$, Chanez $P$, Chiappara $G_{r}$ Merendino $A$, Pace E, Rizzo A, la Rocca AM, Bellia $V$, Bonsignore $G_{\text {, }}$ and Bousquet $J$. Transforming growth factor-beta expression in mucosal biopsies in asthma and chronic bronchitis. Am J Respir Crit Care Med 1997; 156:591-599.

53. Saetta $M$, Mariani $M$, Panina-Bordignon $P$, Turato $G$, Buonsanti $C$, Baraldo $S$, Bellettato $C M$, Papi A, Corbetta L, Zuin R, Sinigaglia F, and Fabbri LM. Increased Expression of the Chemokine Receptor CXCR3 and Its Ligand CXCL10 in Peripheral Airways of Smokers with Chronic Obstructive Pulmonary Disease. Am / Respir Crit Care Med 2002;165:1404-1409.

54. Hogg JC, and Senior RM. Chronic obstructive pulmonary disease - part 2: pathology and biochemistry of emphysema. Thorax 2002;57:830-834.

55. Cottlieb DI, Luisetti M, Stone PJ, Allegra L, Cantey-Kiser JM, Grassi C, and Snider Gil. Short-term supplementation therapy does not affect elastin degradation in severe alpha(1)-antitrypsin 2072 .

56. Luidwig PW, Schwart BA, Hoidal IR, and Niewoehner DE. Cigarette smoking causes accumulation of polymorphonuclear leukocytes in alveolar septum. Am Rev Respir Dis

57. Handbook for proteol

Handbook for proteolytic enzymes. 1998. In A.J. Barret, N.D. Rawlings, and F. Woessner, editors.
ed. Academic Press, llondon, UK.

58. Turk $V$ Turk $B$ and Turk $2001 ; 20: 4629-4633$

Cysteine proteinases and $c$ sstatin $C$ in bronchioka $A$, Tanino $M$, Miyamoto $K$, and Kawakami $Y$. emphysema. Fur Respir J 1998;12:1033-1039.

60. Piccioni PD, Kramps JA, Rudolphus $A$, Bullgheroni $A$, and Luisetti $M$. Proteinase/proteinase inhibitor imbalance in sputum sol phases from patients with chronic obstructive pulmonary disease. Suggestions for a key role pllayed by antileukoprotease. Chest 1992;102:1470-1476.

61. Parks WC, and Shapiro SD. Matrix metalloproteinases in lung biology. Respir Res 2001;2:10-19. Bousquet $J$, and Bonsignore $G$, Sputum , Profita $M$, Chanez $P$, Bellia $V$, Mautino $G$, D'Accardi $P$, 
1 ratio correlates with airflow obstruction in asthma and chronic bronchifis. Am J Respar Cht Care Med 1998;158:1945-1950.

63. Segura-Valdez $L$, Pardo $A$, Gaxiola $M$, Uhal $B D$, Becerril $C$, and Selman $M$. Upregulation of gelatinases $A$ and $\mathrm{B}_{r}$ collagenases 1 and $2_{2}$ and increased parenchymal cell death in $\mathrm{COPO}$. Chest 2000; 117:684-694.

64. Cataldo $D_{*}$ Munaut $C$, Noel $A$, Frankenne F, Bartsch $P$, foidart $M$, and Louis. R. MMP.2- and MMP-9-linked gelatinolytic activity in the sputum from patients with asthma and chronic obstructive pulmonary disease. Int Arch Allergy Immunol 2000;123:259-267.

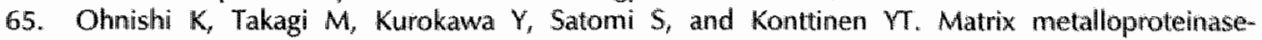
mediated extracellular matrix protein degradation in human pulmonary emplysema. Lab Invest $1998 ; 78: 1077-1087$.

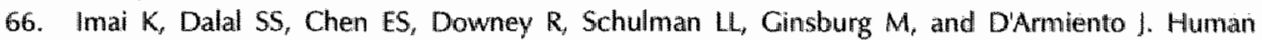
collagenase (matrix metalloproteinase-1) expression in the lungs of patients with emphysema. Am I Respir Crit Care Med 2001;163:786-791.

67. Dekhuijzen PN, Aben KK, Dekker I. Aarts LP, Wielders PL, van Herwaarden CL, and Bast A, Increased exhalation of hydrogen peroxide in patients with stable and unstable chronic obstructive pulmanary disease. Am / Respir Crit Care Med 1996;154:813-816.

68. Maziak W, Loukides S, Culpitt S, Sulliwan $P$, Kharitonov $S A$, and Barnes $P J_{.}$. Exhaled nitric oxide in chronic obstructive pulmonary disease. Am / Respir Crit Care Med 1998;157:998-1002.

69. Report NWW. 2001.Global strategy for the diagnosis, management, and prevention of chronic obstructive pulmonary disease. NHLBI/WHO Global Initiative for Chronic Obstructive Lung Disease (GOLD).

70. Niewoehner DE, Kleinerman J, and Rice DB. Pathologic changes in the peripheral airways of young cigarette smokers. N Engl/Med 1974;291:755-758.

71. Matsuba $\mathrm{K}$, and Thurlbeck WM. The number and dimensions of small airways in emphysematous. lungs. Am I Pathol 1972;67:265-275.

72. Hogg JC, Macklem PT, and Thurlbeck WM. Site and nature of airway obstruction in chronic obstructive lung disease. N Engl / Med 1968;278:1355-1360,

73. Wright $\mathrm{J} L$, Lawson $L$, Pare PD, Hooper RO, Peretz DI, Nelems JM, Schulzer M, and Hogg JC. The structure and function of the pulmonary vasculature in mild chronic obstructive pulmonary disease. The effect of oxygen and exercise. Am Rev Respir Dis 1983;128:702-707.

74. Sekhon HS, Wright $\mathrm{JL}$, and Churg $A$. Cigarette smoke causes rapid cell prolifferation in small ailways and associated pulmonary arteries. Am / Physiol 1994;267:L557-563.

75. Peinado VI, Barbera JA, Ramirez I, Gomez. FP, Roca J, Jover L, Gimferrer JM, and Rodriguez-Roisin R. Endothelial dysfunction in pulmonary arteries of patients with mild COPD. Am J Physiol 1998;274:L908-913.

76. Kasahara Y, Tuder RM, Cool CD, Lynch DA, Flores SC, and Voelket NIF. Endothelial Cell Death and Decreased Expression of Vascular Endothelial Growth Factor and Vascular Enclothelial Growth Factor Receptor 2 in Emphysema. Am / Respir Crit Care Med 2001;163:737-744.

77. Schols AM, Buurman WA, Staal van den Brekel AJ, Dentener MA, and Wouters EF. Evidence for a relation between metabolic derangements and increased levels of inflammatory mediators in a subgroup of patients with chronic obstructive pulmonary disease. Thorax 1996;51:819-824.

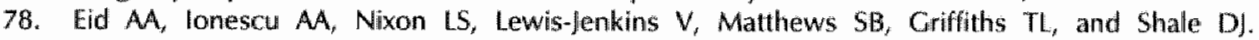
Inflammatory response and body composition in chronic obstructive pulmonary disease. Am I Respir Crit Care Med 2001;164:1414-1418.

79. De Godoy I, Donahoe $M$, Calhoun WJ, Mancino J, and Rogers RM. Elevated TNF-alpha production by peripheral blood monocytes of weight-losing COPD patients. Am / Respir Crit Care Med 1996;153:633-637.

80. Di Francia M, Barbier D, Mege IL, and Orehek J. Tumor necrosis factor-alpha levels and weight lass in chronic obstructive pulmonary disease. Am / Respir Crit Care Med 1994;150:1453-1455.

81. Noguera A, Busquets $X$, Sauleda I, Villaverde IM, MacNee $W$, and Agusti AG Expression of adhesion molecules and $G$ proteins in circulating neutrophils in chronic obstructive pulmonary disease. Am J Respir Crit Care Med 1998;158:1664-1668.

82. Rahman I, Morrison D, Donaldson $K$, and MacNee W. Systemic oxiddative stress in asthma, COPD, and smokers. Am J Respir Crit Care Med 1996; 154:1055-1060. 
03. Sauleda J, Garcia-Paimer $\mathrm{F}$, Gonzalez $G$. Palou $A$ and Agusti AG. The activity of cytochrome oxidase is increased in circulating lymphocytes of patients with chronic obstructive pulmonary disease, asthma, and chronic arthritis. Am J Respir Crit Care Med 2000; 161:32-35.

84. Dentener MA, Creutzberg EC, Schols AM, Mantowani $A$, vant Veer $C$, Buurman WA and Wouters EF. Systemic anitinflammatory mediators in COPD: increase in solubile interleukin 1 receptor II during treatment of exacerbations. Thorax 2001, $56: 721-726$.

85. Takabatake $N$, Nakamura $H$, Abe S, Hino $T$, Saito $H$, Yuki $H$, Kato $S$, and Tonoike $H$. Circulating leptin in paitients with chronic obstructive pulmonary disease. Am / Respir Crit Care Med $1999 ; 159: 1215-1219$.

86. Takabatake Nakamura $H$, Abe $S$, Inove $S$, Hino T, Saito $H$, Yuki $H$, Kato $S$, and Tomoike $H$. The relationship between chronic hypoxemia and activation of the tumor necrosis factor-alpha system in patients with chronic obstructive pulmonary disease. Am / Respir Crit Care Med $2000 ; 161: 1179-1184$.

87. Dahl $M$, Tybjaerg-Hansen $A$, Vestbo J, Lange $P$, and Nordestgaard $B G$. Elevated plasma fibrinogen associated with reduced pulmonary function and increased risk of chronic obstructive pulmonary disease. Am J Respir Crit Care Med 2001;164:1008-1011.

B8. Engelen MP, Schols AM, Lamers R!, and Wouters EF. Different patterns of chronic tissue wasting among patients with chronic obstructive pulmonary disease. Cin Nutr 1999; 18:275-280.

89. Campfield LA, Smith Fl, and Burn P. The $O B$ protein (leptin) pathway-a link between adipose tissue mass and central neural networks. Horm Metab Res 1996;28:619-632.

90. Huang L, and Li C. Leptin: a multifunctional hormone. Cell Res 2000;10:81-92.

91. Schols AM, Creutzberg EC, Buurman WA, Campfield LA, Saris WH, and Wouters EF. Plasma leptin is related to proinilammatory status and dietary intake in patients with chronic obstructive pulmonary disease. Am / Respir Crit Care Med 1999;160:1220-1226.

92. Cosker HR, van Mameren $H$, van Dijk PJ, Engelen MP, van der Vusse GJ, Wouters EF, and Schols AM. Skeletal muscle fibre-type shifting and metabolic profile in patients with chronic obstructive pulmonary disease. Eur Respir / 2002;19:617-625.

93. ATS. Skeletal muscle dysfunction in chronic obstructive pulmonary disease. A statement of the American Thoracic Society and European Respiratory Society. Am / Respir Crit Care Med 1999; 159:51-40.

94. Culpitt SV, Maziak W, Loukidis S, Nightingale JA, Matthews JL, and Barnes PJ. Effect of high dose inhaled steroid on cells, cytokines, and proteases in induced sputum in chronic obstructive pulmonary disease. Am I Respir Crit Care Med 1999;160:1635-1639.

95. Keatings VM, Jatakanon A, Worsdell YM, and Barnes PJ. Effects of inhaled and oral glucocorticoids on inflammatory indices in asthma and COPD. Am / Respir Crit Care Med $1997 ; 155: 542-548$.

96. Paggiaro PL, Dahle R, Bakran I, Frith L, Hollingworth K, and Efthimiou I. Multicentre randomised placebo-controlled trial of inhaled fluticasone propionate in patients with chromic obstructive pulmonary disease. International COPD Study Group [see comments]. Lancet 1998;351:773 780.

97. Burge PS, Calverley PM, Jones PW, Spencer S, Anderson JA, and Maslen TK. Randomised, double blind, placebo controlled study of fluticasone propionate in patients with moderate to severe chronic obstructive pulmonary disease: the ISOLDE trial, Bmj 2000;320:1297-1303.

98. Vestbo 1, Sorensen T, Lange P, Brix A, Torre P, and Viskum K. Long-term effect of inhaled budesonicle in mild and moderate chronic abstructive pulmonary disease: a randomised controlled trial Lancet 1999;353:1819-1823.

99. Pauwels $R A$, Lofdahl $C_{\text {, }}$ Laitinen LA, Schouten JP, Postma DS, Pride NB, and Ohlsson SV. Longlem treatment with inhaled budesonide in persons with mild chronic obstructive pulmonary disease who continue smoking. European Respiratory Society Study on Chronic Obstructive
Pulmonary Disease. N Engl / Med 1999;340:1948-1953.

100. Anthonisen NR, Connett $\mathbb{E}$, Kiley JP, Altose MD, Bailey WC, Buist AS, Conway WA, Jr, Enright $\mathrm{PL}$, Kanner RE, OHara $P$, and et all. Effects of smoking intervention and the use of an inhaled anticholinergic bronchodilator on the rate of decline of FEV1. The Lung Health Study. Jama
$1994 ; 272: 1497 \times 1505$.

101. Kanner RE, Connett JE, Williams $D E$, and Buist AS. Effects of randomized assignment to a smoking cessation intervention and changes in smoking habits on respiratory symptoms in 
smokers with early chronic obstructive pulmonary disease: the Lung Health Study. Am / Mted 1999; $106: 410-416$.

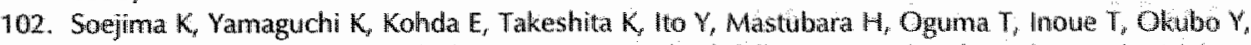
Amakawa $K$, Tateno $H$; and Shiomi T. Longitudinal follow-up study of smoking-induced lung density changes by high-resolution computed tomography. Am \& Respir Crit Care Med 2000; 161:1264-1273.

103. Mullen JB, Wright IL, Wiggs $B R$, Pare PD, and Hogg JC. Structure of central airways in current smokers and ex-smokers with and without mucus hypersecretion: relationship to lung function. Thorax 1987;42:843-848.

104. Yamamoto $C$, Yoneda $T$, Yoshikawa $M, F u$ A, Tokuyama T, Tsukaguchi $K$, and Narita N. Airway inflammation in COPD assessed by sputum levels of interleukin-8. Chest 1997;112:505-510.

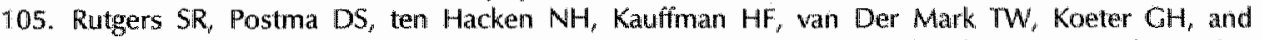
Timens W. Ongoing airway inflammation in patients with COPD who do not currently smoke. Thorax 2000;55:12-18.

106. Willemse $B W$, Ten Hacken NH, Rutgers $B, C$. $U_{\star}$ Postma DS, and Timens $W$. The effect of one year smoking cessation on neutrophilic inflammation in smokers with and without COPD. AmI Respir Crit Care Med 2002;165:A463.

107. Robinson NE, Derksen F], Olszewski MA, and Buechner-Maxwell VA. The pathogenesis of chronic obstructive pulmonary disease of horses. Br Vet / 1995; 152:283-306.

108. Snider GL, J. K, Thurlbeck WM, and al. e. The definition of emphysema: report of a National Heart, Lung, and Blood Institure; Devision of Lung Diseases Workshop. Am Rev Respir Dis 1985:132:182-185.

109. Shapiro SD. Mighty mice: transgenic technology "knocks out" questions of matrix metalloproteinase function. Matrix Biol 1997;15:527-533.

110. Gross PE, Pfitzar $E$, Tolker $M$, Babyak $M$, and Kaschak $M$. Experimental emphysema: its production with papain in normal and silicotic rats. Arch. Environ. Health 1965;11:50-58.

111. Kuln $C, Y u S Y$, Chraplyvy $M$, Linder $H_{r}$ and Senior RM. The induction of emphysema with elastase. 1I. Changes in connective tissue. Lab Invest 1976;34:372-380.

112. Senior RM, Tegner $H$, Kuhn $C_{\text {, }}$ Ohlsson $K$, Starcher $B C$, and Pierce $J A$. The induction of pulmonary emphysema with human leukocyte elastase. Am Rev Respir Dis 1977;116:469-475.

113. Janoff $A$, Sloan $B$, Weinbaum $G_{1}$, Damiano $V$, Sandhaus $R A$, Elias $J$, and Kimbel P. Experimental emphysema induced with purified human neutrophil elastase: tissue localization of the instilled protease. Am Rev Respir Dis 1977;115:461-478.

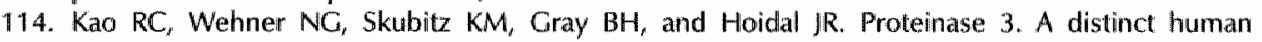
polymorphonuclear leukocyte proteinase that produces emphysema in hamsters. I Clin Invest 1988;82:1963-1973.

115. Shapiro SD. Animal models for chronic obstructive pulmonary disease: age of klotho and marlboro mice. Am / Respir Cell Mol Biol 2000;22:4-7.

116. Massaro GD, and Massaro D. Retinoic acid treatment abrogates elastase-induced pulmonary emphysema in rats. Nat Med 1997;3:675*677.

117. Hautamaki RD, Kobayashi DK, Senior RM, and Shapiro SD. Requirement for macrophage elastise for cigarette smoke-induced emphysema in mice. Science 1997;277:2002-2004.

118. Cavarra $E$, Bartalesi $B$, Lucattelli $M$, Fineschi 5 , Lunghi $B$, Gambelli $F$, Ortiz LA, Martorana PA, and Lungarella G. Effects of Cigarette Smoke in Mice with Different Lewels of alpha(1)-Proteinase Inhibitor and Sensitivity to Oxidants. Am / Respir Crit Care Med 2001;164:886-890.

119. Snider $\mathrm{GL}$, Lucey EC, Faris $\mathrm{B}_{r}$ Jung-Legg $Y$, Stone $\mathrm{P}$, and Franzblau $\mathrm{C}$. Cadmium-chloride-induced air-space enlargement with interstitial putmonary fibrosis is not associated with destruction of lung elastin. Implications for the pathogenesis of human emphysema. Am Rev Respir Dis $1988 ; 137: 918-923$.

120. Chitano P, Hosselet If, Mapp CE, and Fabbri LM. Effect of oxidant air pollutants on the respiratory system: insights from experimental animal research. Eur Respir / 1995;8:1357-1371.

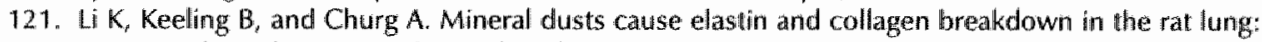
a potential mechanism of dust-induced emphysiema. Am / Respir Crit Care Med 1996;153:644649.

122. Kielty $C M$, Raghunath $M$, Siracusa LD, Sherratt MJ, Peters R, Shuttleworth $C A$, and Jimenez $S A$. The Tight skin mouse: demonstration of mutant fibrillin-1 production and assembly into abnormal microfibrils. J Cell Biol 1998;140:1159-1166. 
123. Keil $M$, Lungarella $G$, Cavarra $E_{f}$ van Even $P$, and Martorana $P A$. A scanning electron microscopic investigation of genetic emphysema in tight-skin, pallid, and beige mice, three different C57 BU/6) mutants. Lab linvest 1996;74:353-362.

124. Fisk DE, and Kuhn C. Emphysemallike changes in the lungs of the blotchy mouse. Am Rev Respir Dis 1976;113:787-797.

125. Perou $C M$, Justice $M$ J, Pryor $\mathbb{R}$ J, and Kaplan J. Complementation of the beige mutation in culltured cells by episomally replicating murine yeast artificial chromosomes. Proc Natl Acad Sci U 5 A $1996 ; 93: 5905-5909$.

126. Nagle DL, Karim MA, Woolf EA, Holmgren $L_{\text {, Bork }}$, Misumi DJ, MCGraill SH, Dussault BJ, Jr. Perou CM, Boissy RE, Duyk GM, Spritz RA, and Moore KJ. Identification and mutation analysis of the complete gene for Che diak-Higashi syndrome. Nat Genet 1996;14:307-311.

127. DiArmiento I, Dalal $S S$, Okada $Y$, Berg RA, and Chada $K$. Collagenase expression in the lungs of transgenic mice causes pulmonary emphysema. Cell 1992;71:955-961.

128. Fujita $M$, Shannon JM, irvin $C_{r}$ Fagan KA, Cool $C_{r}$ Augustin $A_{t}$ and Mason RJ. Overexpression of tumor necrosis factor-alpha produces an increase in lung volumes and puimonary hypertension. Am J Physiol Lung Cell Mol Physiol 2001;280: L39-49.

129. Wang $Z$, Zheng $\mathbb{T}$, Zhu $Z$, Homer RJ, Riese RJ, Chapman HA, Jr., Shapiro SD, and Elias $J A$. Interferon gamma induction of pulmonary emphysema in the adult murine lung. $J$ Exp Med 2000; 192:1587-1600.

130. Kuhn $C_{x}$ 3rd, Homer $\mathrm{Rl}_{\text {, }} Z$ Zhu $Z$, Ward $N$, Flavell $R A$, Geba GP, and Elias $\| A$. Airway hyperresponsiveness and airway obstruction in transgenic mice. Morphologic correlates in mice overexpressing interleukin (1L)-11 and IL-6 in the lung. Am / Respir Cell Mol Biol 2000;22:289. 295.

131. Zhu $Z$, Homer $R$ l, Wang $Z$, Chen $Q$, Geba GP, Wang I, Zhang $Y$, and Elias JA. Pulmonary expression of interleukin-13 causes inflammation, mucus hypersecretion, subepithelial fibrosis, physiologic abnormalities, and eotaxin production. / Clin inwest 1999; 103:779-788.

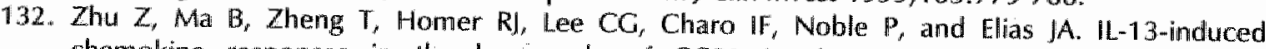
chemokine responses in the lung: role of CCR2 in the pathogenesis of 1L-13-induced inflammation and remodeling. J Immumol 2002; 168:2953-2962.

133. Weinstein $M, X u X$, Ohyama $K$, and Deng $C X$. FGFR-3 and FGFR-4 function cooperatively to direct alveogenesis in the murine lung. Development 1998;125:3615-3623.

134. Yoshida $M$, Korfhagen TR, and Whitsett JA. Surfactant Protein D Regulates NF-kappaB and Matrix Metalloproteinase Production in Alveolar Macrophages via Oxidant-Sensitive Pathways. I

135. Leco KJ, Waterhouse P, Sanchez $\mathrm{OH}$, Gowing KL, Poole AR, Wakeham A, Mak TW, and Khokha $R$. Spontaneous air space enlargement in the lungs of mice lacking tissue inhibitor of metalloproteinases-3 (TIMP-3). J Chin lowest 2001;108:817-829.

136. Suga $T$, Kurabayashi $M$, Sando $Y$, Ohyama $Y$, Maeno $T$, Maeno $Y$, Aizawa $H$, Matsumura $Y$, Kuwaki $T$, Kuro $O M$, Nabeshima $Y$, and Nagai $R$. Disruption of the klotho gene causes pumonary emphysema in mice. Defect in maintenance of pulmonary integrity during postnatal life. Am J
Respir Cell Mol Biol $2000 ; 22: 26-33$.

137. Hasday JD, Bascom R, Costa UI, Fitzgerald T, and Dubin W. Bacterial endotoxin is an active component of cigarette smoke. Chest 1999;115:829-835.

138. Bonner $\mathrm{JC}$, Rice $\mathrm{AB}$, Lindroos $\mathrm{PM}$, O'Brien $\mathrm{PO}$, Dreher $\mathrm{KL}$, Rosas I, Alfaro-Moreno $\mathrm{E}_{i}$ and Osornio-Vargas AR. Induction of the lung myofibroblast PDGF, Roseptos $\mathrm{I}_{\text {, Alfaro-Moreno } \mathrm{E}_{r} \text { and }}$
particles from Mexico City. Am / Respir Cell Mol Biol 1998;19:672-680.

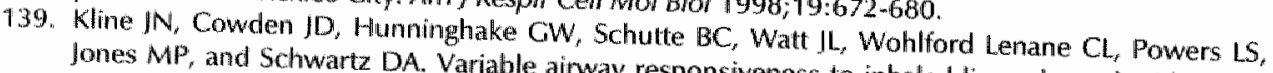

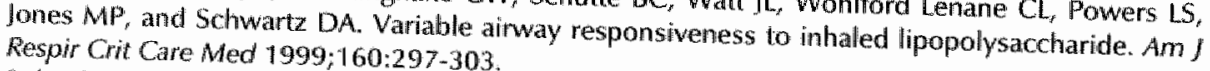

140. Rylander R, Haglind $P_{\text {, and L }}$ andholm $M$. Endotoxin in cotton dust and respiratory function
decrement among cotton workers 1985;131:209-213. Cotton workers in an experimental cardroom. Am Rev Respir Dis 141. Del A, Codshali MA, and Palmgren MS. Gram-negative backerial endotoxins in grain elevator
dusts. Am $/$ nd Hyg Assoc/ $1984 ; 45: 336-339$.

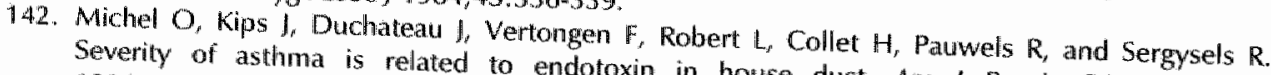
1996;154:1641-1646. 
143. Alexander $\mathrm{C}$, and Rietschel ET. Bacterial lipopolysacoliarides and innate immunty. ) Endotoxim Res 2001:7:167-202.

144. Inohara $N_{,}$Ogura $Y_{*}$ Chen FF, Muto $A_{i}$ and Nunez $\mathrm{G}$. Human Nod1 confers responsiveness to bacterial lipopolysaccharides. J Biol Chem $2001 ; 276: 2551-2554$.

145. Dentener MA. Host defense to bacterial endotoxin. Maastricht: Maasticht University; 1996.

146. Hartung $\mathrm{J}$, and Seedorf 1 . Orienting endotoxin measurement in the atmosphere. OTW Dtsch Tierarz Wochenschr 1999; 106:522-525.

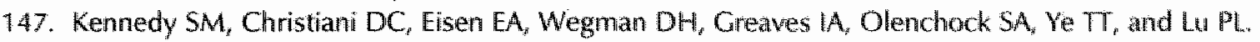
Cotton dust and endotoxin exposure-response relationships in cotton textile workers. Am Rev Respir Dis 1987;135:194-200.

148. Schwartz DA, Donham Kl, Olenchock SA, Popendor( W], Van Fossen DS, Burmeister LF, and Merchant IA. Determinants of longitudinal changes in spirometric function arnong swine confinement operators and farmers. Am / Respir Crit Care Med 11995;151:47-53.

149. Milton DK, Wypij $\mathrm{D}$, Kriebel $\mathrm{D}_{f}$ Walters $M D$, Hammond $S K_{r}$ and Evans JS. Endotoxin exposureresponse in a fiberglass manulacturing facility. Am J Ind Med 1996;29:3-13.

150. Zhiping W, Malmberg P. Larsson BM, Larsson K, Larsson L, and Saraf A. Exposure to bacteria in swine-house clust and acute inflammatory reactions in humans. Am / Respir Crit Care Med 1996; 154:1261-1266.

151. Michel $O$, Nagy AM, Schroeven $M$, Duchateau J, Neve J, Fondu $P$, and Sergysels $R$. Doseresponse relationship to inhaled endotoxin in normal subjects. Am / Respir Crit Care Med $1997 ; 156: 1157-1164$.

152. Rylander $\mathbb{R}$, Bake $B$, Fischer $J$, and Helander $I M$. Pulmonary function and symptoms after inhalation of endotoxin. Am Rev Respir Dis 1989;140:981-986.

153. Sandstrom T, Bjermer $L$, and Rylander R. Lipopolysaccharide (LPS) inhalation in healthy subjects increases neutrophils, lymphocytes and fibronectin levels in bronchoalveolar lavage fluid. Eur Respir] 1992;5:992-996.

15.4. Jagielo PJ, Thorne PS, Watt JL, Frees KL, Quinn TJ, and Schwartz DA. Grain dust and endotoxin inhalation challenges produce similar inflammatory responses in normal subjects. Chest 1996; 110:263-270.

155. Clapp WD, Becker S, Quay I. Watt JL, Thome PS, Frees KL, Zhang X, Koren HS, Lux CR, and Schwartz DA. Grain dust-induced airflow obstruction and inflammation of the lower respiratory tract. Am J Respir Crit Care Med 1994;150:611-617.

156. Wesselius LI, Nelson ME, Bailey K, and O'Brien Ladner AR. Rapid lung cytokine accumulation and neutrophil recruitment after lipopolysaccharide inhalation by cigarette smokers and nonsmokers. J Lab Clin Med 1997;129:106-114.

157. Schulz $C_{x}$ Farkas L, Wolf $K$, Kratzel $K$, Eissner $G$, and Pfeifer $M$. Differences in LPS-induced activation of bronchial epithellial cells. (BEAS-2B) and type II-like pneumocytes (A-549). Scand) Immunol 2002;56:294-302.

158. Michel O, Duchateau J, and Sergysels R. Effect of inhaled endotoxin on bronchial reactivity in asthmatic and normal subjects. I App/ Physiol 1989;66:1059-1064.

159. Cavagna $G$, Foa $V$, and Vigliani EC. Effects in man and rabbits of inhalation of cotton dust or extracts and purfified endotoxins. Br / Ind Med 1969;26:314-321.

160. Arbour NC, Lorenz E, Schutte BC, Zabner I, Kline JN, Jones M, Frees K, Watt IL, and Schwartz DA. TLR4 mutations are associated with endotoxin hyporesponsiveness in humans. Nat Gene? 2000;25:187-191.

161. Xing $Z$, Jordana $M$, Kirpalani $H$, Driscoll KE, Schall TJ, and Gauldie J. Cytokine expression by neutrophils and macrophages in vivo: endotoxin induces tumor necrosis factormalipha, macrophage inflammatory protein-2, interleukin-1 beta, and interleukin-6 but not RANTES or transforming growth factor-beta $1 \mathrm{mRNA}$ expression in acute lung inflammation Ipublished erratum appears in Am \& Respir Cell Mol Biol 1994 Mar; 10(3):following 346]. Am / Respir Cell Mol Biol 1994;10:148-153.

162. Shi $M M_{*}$, Chong IW, Long NC, Love IA, Godleski Jl, and Paulauskis JD. Functional characterization of recombinant rat macrophage inflammatory protein-1 alpha and mRNA expression in pulmonary inflammation. Inflammation 1998;22:29 43.

163. Johnston Cl, Finkelstein JN, Gelein R, and Oberdorster G. Pulmonary cytokine and chemokine mRNA levels after inhalation of lipopolysaccharide in C57BL/6 mice. Toxicol Sici 1998;46:300307. 
164. Blackwell TS, Lancaster LH, Blackwell TR, Venkatakrishnan A, and Christman JW. Differential NFkappab activation after intratractieal endotoxin. Am / Physiol 1999;277:L823-830.

165. Beck-Schimmer $B$, Madjdpour $C$, Kneller $S$, Ziegler $U$, Pasch $T$, Wuthrich RP, Ward PA and Schimmer RC. Role of alveolar epithelial ICAM-1 in lipopolysaccharide-induced lung inflammation. Eur Respir / 2002;19:1142-1150.

166. Zhang P, Bagby CJ, Kolls JK, Welsh DA, Summer WR, Andresen J, and Nelson S. The effects of granulocyte colony-stimulating factor and neutrophil recruitment on the pullmonary chemokine response to intratracheal endotoxin. I Immunol 2001; 166:458-465.

167. Ulich $F R$, Watson LR, Yin $S M$, Guo $K Z$, Wang $P$, Thang $H$, and cjel Castillo J. The intratracheal administration of endotoxin and cytokines. I. Characterization of LPS-induced $I L-1$ and TNF mRNA expression and the LPS-, IL-1-, and TNF-induced inflammatory infiltuate. Am / Pathol $1991 ; 138: 1485-1496$.

168. Ulich TR, Howard SC, Remick DG, Yi ES, Collins T, Guo K, Yin S, Keene JL, Schmuke J], Steininger $C N$, and et al. Intratracheal administration of endotoxin and cytokines: VIII. LPS induces Eselectin expression; anti-E-selectin and soluble E-selectin inhibit acute inflammation. Inflammation 1994;18:389-398.

169. Tang WW, Yi ES, Remick DG, Wittwer $A$, Yin 5 , Qi M, and Ulich TR Intratracheal injection of endotoxin and cylokines. IX. Contribution of CD11a/ICAM-1 to neutrophil emigration. Am I Physiol 1995;269:L653-659.

170. Mizgerd JP, Scott ML, Spieker MR, and Doerschuk CM. Functions of IkappaB proteins in inflammatory responses to Escherichia coli LPS in mouse lungs. Am / Respir Cell Mol Biol $2002 \times 27: 575 \cdot 582$.

171. Hirano $S$. Quantitative time-course profiles of bronchoalveolar lavage cells following intratracheal instillation of lipopolysaccharide in mice. Ind Health 1997;35:353-358.

172. Wagner $J G$, and Roth RA. Neutrophil migration during endotoxemia. / Leukoc Biol 1999;66;1024.

173. Li $X Y$, Donaldson $K_{r}$ and MacNee $W$. Lipopolysaccharide-induced alveolar epithelial permeability: the role of nitric oxide. Am / Respir Crit Care Med 1998; 157:1027-1033.

174. Cox G, Crossley J, and Xing Z. Macrophage engulfment of apoptotic neutrophils contributes to the resolution of acute pulmonary inflammation in vivo. Am / Respir Cell Mol Biol 1995;12:232237.

175. Haslett C. Granulocyte apoptosis and its role in the resolution and control of lung inflammation. Am J Respir Crit Care Med 1999:160:55-11.

176. Yanagihara $K$, Seki $M$, and Cheng PW. Lipopolysaccharide Induces Mucus Cell Metaplasia in Mouse Lung. Am / Respir Cell Mol Biol 2001;24:66-73.

177. Mclntosh JC, Swyers AH, Fisher JH, and Wright JR. Surfactant proteins A and D increase in response to intratracheal lipopolysaccharide. Am / Respir Cell Mol Biol 1996;15:509-519.

178. Sugahara $K$, lyama $K$, Sano K, Kuroki $Y$, Akino T, and Matsumoto M. Overexpression of surfactant protein $S P-A_{i} S P-B$, and $S P-C$. $D R N A$ in rat lungs with lipopolysaccharide-induced injury. Lab Invest $1996 ; 74: 209-220$

179. Crestani B, Rolland C, Lardeux B, Foumier T, Bernuau D, Pous C, Vissuzaine $C$, Li L, and Aubier M. Inducible expression of the alphat-acid glycoprotein by rat and human type II alveolar epithelial cells. I Immunot 1998;160:4596-4605.

180. Klein RD, Su GL, Aminlari $A$, Alarcon $W H$, and Wang SC. Pulmonary LPS-binding protein (LBP) upregulation following LPS-mediated injury. / Surg Res 1998; 78:42-47.

181. Fehrenbach H. Alveolar epithelial type II cell: defender of the alveolus revisited. Respir Res $2001 ; 2: 33-46$.

182. Stolk J, Rudolphus $A$, Dawies P, Osinga D, Dijkman $\| H_{*}$, Aganwal L, Keenan KP, Fletcher $D$, and Kramps IA. Induction of emphysema and bronchial mucus cell hyperplasia by intratracheal instillation of lipopolysaccharide in the hamster. J Pathol 1992;167:349-356.

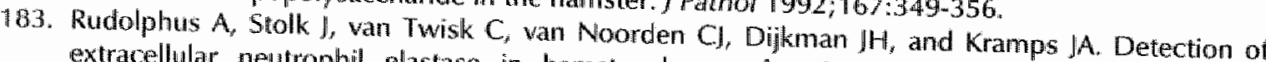
extracellular neutrophil elastase in hamster lungs after intratracheal instillation of $E$. coli lipopolysaccharide using a fluorogenic, elastase-specific, synthetic substrate. Am J Pathol

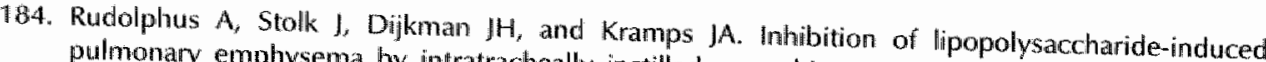
pulmonary emphysema by intratracheally instilled recombinant secretory leukocyte proteinase
inhibitor. Am Rev Respir Dis 1993;147:442-447. 
185. Stolk $J$, Heinzel Wieland $R$, Saunders $D$, Dijkman $J H$, and Steffens G. Potency of an oxidationresistant mutant of secretory leukocyte proteinase inhibitor in lipopolysaccharide-induced emphysema in hamsters. Pulm Pharmacol 1993;6:33-39.

186. Stolk J, Rossie $W$, and Dijkman IH. Apocynin improves the efficacy of secretory leukecyte protease inhibitor in experimental emphysema. Am / Respir Crit Care Med 1994;150:1628:1631.

187. Toward TI, and Broadley KJ. Goblet cell hyperplasia, airway function, and teukocyte infittration after chronic lipopolysaccharide exposure in conscious Guinea pigs: effects of rolipram and dexamethasoine. J Pharmacol Exp Ther 2002;302:814-821.

188. Toward TJ, and Broadley KJ. Ainway reactivity, inflammatory cell influx and nitric oxide in guineapig ainways after lipopolysaccharide inthatation. Br \& Pharmacol 2000;131:271-281.

189. Toward TJ, and Broadley KJ. Chronic lipopolysaccharide exposure on ainway function, cell infittration, and nitric oxide generation in conscious guinea pigs: effect of rolipram and dexamethasone. / Pharmacol Exp Ther 2001;298:298-306.

190. Harkema JR, and Hotchkiss JA. Ozone- and endotoxin-induced mucous cell metaplasias in rat airway epithelium: novel animal models to study toxicant-induced epithelial transformation in airways. Toxicol Lett 1993;68:251-263.

191. Corbel $M$, Theret $N$, Caulet-Maugendre $S$, Germain $N$, Lagente $V$, Clement $B$, and Boichot $E$. Repeated endotoxin exposure induces interstitial fibrosis associated with enhanced gelatinase (MMP-2 and MMP-9) activity. Inflamm Res 2001;50:129-135.

192. Sawov JD, Gavett $\mathrm{SH}$, Brass $\mathrm{DM}_{4}$ Costa $\mathrm{DL}$, and Schwartz DA. Neutrophils play a critical role in development of LPS-induced airway disease. Am / Physiol Lung Cell Mol Physiol 2002;283:L952962.

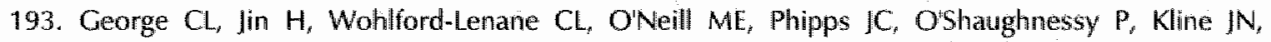
Thorne PS, and Schwartz DA. Endotoxin responsiveness and subchronic grain dust-induced airway disease. Am / Physiol Lung Cell Mol Physiol 2001;280:L203-2113. 


\section{CHAPTER 2}

\section{Aims and outline of the thesis}

Until a decade ago, little effort has been put into investigating the molecular and cell biology of COPD and into development of new treatments. COPD is, however, a disease with a worldwide rise in incidence and a large consumption of health care costs. The last years, COPD has received more attention leading to an increase in the knowledge on COPD. Studies on chronic local inflammatory response in patients with COPD demonstrated a specific cellular pattern consisting of predominantly macrophages, neutrophils, and CD8 + T-lymphocytes that, however, varies in the different compartments of the lung. Cytokines and chemokines were shown to be involved in recruitment of these inflammatory cells. In addition, members of the MMP family were suggested to play a role in the progression of emphysema, although a causal relationship between MMP activity and tissue destruction has as yet not been demonstrated. Furthermore, there is increasing evidence of systemic (i.e. extrapulmonary) inflammation in patients with COPD, which is considered to have an important negative influence on the quality of life. At present, however, information regarding the role of chronic inflammation - both local and systemic - in the pathogenesis of COPD is still limited and fragmentary.

Recent studies indicate that LPS may have a larger role in the chronic inflammatory process in COPD than previously realized. LPS is major constituent of Gram-negative bacteria, with strong pro-inflammatory capacities both in vitro and in vivo. The respiratory system of patients with COPD is continuously exposed to LPS due to chronic inhalation of airborne particles like cigarette smoke, organic dusts, and air pollution (indoor-outdoor) as well as aspiration of bacteria in case of chronic infection. However, inflammatory and pathologic effects of acute and chronic LPS exposure to the lung are currently not fully investigated.

Therefore, the aims of the present thesis were:

- To investigate the relationship between local and systemic inflammation in COPD patients, and to further characterize the local inflammatory response;

- To study the effects of acute and long-term LPS exposure to the lung in vivo using an experimental animal model.

In Chapter 3 and 4, we investigated the relationship between the local inflammatory response in the respiratory organ and systemic inflammation in patients with mild-to-moderate COPD. We assessed airway inflammation using 
induction of sputum by inhalation of hypertonic saline, which is a safe, noninvasive, and reproducible method to determine cell counts and protein concentrations in the airway compartment of patients with COPD. In Chapter 3 , levels of STNF-receptors, TNF- $\alpha$, and IL- 8 in induced sputum and plasma were compared between COPD patients and healthy smokers matched for age and smoking history. Furthermore, persistence of the local and systemic inflammatory response was assessed by comparing current smokers and ex-smokers. In Chapter 4, levels of three major acute-phase reactants - AGP, CRP, and LBP - in induced sputum and the circulation were compared between COPD patients and healthy smokers.

In Chapter 5 and 6, we further characterized the local inflammatory response in patients with mild-to-moderate COPD. In Chapter 5, we assessed sputum levels of leptin and focussed on the role of leptin as proinflammatory mediator in the local inflammatory response in COPD. In Chapter 6 , we investigated activity of three major matrix metalloproteinases - MMP-1, MMP-8, and MMP-9 - in induced sputum of COPD patients.

In Chapter 7 and 8, we assessed effects of acute intratracheal LPS instillation using a well-characterized murine model, and emphasis was placed on airway injury as well as acute-phase response induced by local LPS exposure. In Chapter 7 , apoptotic cell death in bronchial epithelial cells was assessed and the role of infiltrating neutrophils and TNF- $\alpha$ in LPS-induced apoptosis was investigated. In Chapter 8 , the effects of local LPS exposure on both pulmonary and hepatic expression of four major acute-phase reactants - SAP, AGP, LBP, and $\alpha_{1}-A T$ - were assessed.

In Chapter 9, the inflammatory and pathological effects of long-term LPS exposure to the lung were investigated in detail. To this end, a murine model in which mice were exposed to repeated intratracheal instillation of E.coli LPS was developed.

Chapter 10 comprises the general discussion of the thesis and gives implications for future investigations. 


\section{CHAPTER 3}

\section{Local and systemic inflammation in patients with chronic obstructive pulmonary disease: soluble TNF-receptors are increased in sputum}

Juanita H.J. Vernooy", Mehmet Küçükaycan', Jan A. Jacobs' ${ }^{2}$ Niels H. Chavannes $^{3}$, Wim A. Buurman ${ }^{4}$, Mieke A. Dentener', Emiel F.M. Wouters'

Departments of ${ }^{1}$ Respiratory Medicine, ${ }^{2}$ Medical Microbiology, ${ }^{3}$ General Practice and ${ }^{4}$ General Surgery, University Hospital Maastricht, Maastricht, The Netherlands

American Journal of Respiratory and Critical Care

Medicine 2002; 166: 1218-1224

\section{ABSTRACT}

Chronic obstructive pulmonary disease (COPD) is characterized by significant chronic inflammation in the pulmonary compartment as well as in the circulation. This study aimed to elucidate the relationship between local and systemic inflammation in smoking-induced COPD by assessing levels of soluble (s) tumor necrosis factor (TNF) receptors, TNF- $\alpha$, and interleukin-8 (IL-8) in induced sputum and in plasma. Sputum induction was performed in 18 subjects with COPD (FEV $56 \%$ predicted) and 17 healthy smokers ( $F E V_{1}$ 99\% predicted). Patients with COPD showed significantly higher percentages of neutrophils and levels of STNF. R55 and IL-8 in sputum as compared with control subjects, whereas sputum STNF-R75 levels tended to be higher in COPD. Sputum TNF- $\alpha$ levels were similar in both groups. When comparing STNF receptors in sputum and plasma, no direct correlations were found despite elevation of circulating STNF-R75 levels in patients with COPD. In addition, sputum STNF receptors were inversely related to the FEV in patients with COPD, whereas circulating STNF receptors were not, suggesting different regulation of inflammation in the pulmonary and systemic compartment. When subjects were divided according to their current smoking status, levels of sTNF-R55, STNF-R75, and IL-8 in sputum were significantly elevated in ex-smoking versus currently smoking patients with COPD, suggesting ongoing inflammation in airways and circulation of patients with COPD after smoking cessation. 


\section{INTRODUCTION}

Chronic obstructive pulmonary disease (COPD) is characterized by the progressive development of airflow limitation that is not fully reversible (reviewed by Barnes ${ }^{1}$ ). The main risk factor for COPD is cigarette smoking, and at present, cessation of smoking is the only intervention with a significant attenuation of the degree of lung function impairment ${ }^{2-4}$. There is increasing evidence that COPD is associated with a chronic inflammatory response in both airways and lung parenchyma. Histopathologic studies have shown that patients with COPD have increased numbers of macrophages and $\mathrm{CD} 8+\mathrm{T}$ cells in the peripheral airways and lung parenchyma ${ }^{5-s}$, which may be associated with latent adenoviral infection $^{\varphi, 10}$. On the other hand, a marked increase in neutrophils in sputum and bronchoalveolar lavage fluid was demonstrated in patients with COPD compared with control subjects ${ }^{13,12}$, reflecting neutrophilia in the central airways ${ }^{13}$. The extent of neutrophilia correlated with the degree of airflow limitation ${ }^{12,14,15}$. Analysis of induced sputum revealed that levels of interleukin-8 (IL-8) and tumor necrosis factor- $\alpha$ (TNF- $\alpha$ ), which are generally considered to be important mediators in neutrophil recruitment, are elevated in patients with COPD ${ }^{14,16,17}$. In addition, elevated levels of neutrophil granule proteins were demonstrated in induced sputum and bronchoalveolar lavage fluid from patients with severe COPD and smoking subjects with subclinical emphysema, respectively, indicating activation of recruited neutrophils ${ }^{16,19}$.

TNF- $\alpha$ is a potent proinflammatory cytokine known to exert its activities by interaction with two structurally related, but functionally distinct, transmembrane receptors, referred to as TNF-R55 and TNF-R75 in accordance with their molecular weight (reviewed by Aderka ${ }^{20}$ ). Although the two receptors are independently coexpressed on the surface of most cell types, several studies have shown that TNF-R55 is mainly expressed on cells of epithelial origin, whereas TNF-R75 is primarily found on the cell surface of cells of myeloid origin ${ }^{21,22}$. A variety of inflammatory stimuli, including endogenous TNF- $\alpha$ formation ${ }^{23}$, is known to induce proteolytic shedding of the extracellular cytokine-binding domains of the TNF receptors. Therefore, soluble TNF (STNF) receptors are often considered as markers of a proinflammatory state.

Besides the presence of chronic local inflammation in the respiratory organ, there is increasing evidence of systemic inflammation in patients with stable disease as well as during episodes of acute exacerbations. Recent studies demonstrated that levels of STNF-R55 and STNF-R75 were significantly increased in the circulation of patients with $\mathrm{COPD}^{24 \cdot 28}$. The presence of a systemic inflammatory response has an important influence on the quality of life as weight loss and muscle wasting are linked to systemic inflammation ${ }^{24.28-30}$. The main cause for the presence of systemic inflammation in patients with COPD still remains to be elucidated. Systemic hypoxia is suggested to be a good candidate, as systemic hypoxia is associated with activation of the TNF- $\alpha$ system in patients with $\mathrm{COPD}^{27}$. However, no information is yet available comparing the local inflammatory involvement in the respiratory organ with the presence of a systemic 
inflammatory response in COPD. In addition, except for elevation of TNF-a in sputum of patients with COPD, no information is currently available about sTNF receptors in sputum of patients with COPD. Therefore, this study is directed at unraveling the relationship between local and systemic inflammation in COPD. To this end, levels of STNF receptors, TNF- $\alpha$, and IL-8 in induced sputum and plasma were compared. Furthermore, persistence of the local and systemic inflammatory response after smoking cessation was assessed. To this end, subjects were divided according to their current smoking status, and levels of inflammatory mediators in induced sputum and plasma were compared between current smokers and exsmoking individuals who completely abstained for at least 1 year.

\section{MATERIAL \& METHODS}

\section{Subjects}

Eighteen patients with smoking-related, clinically stable COPD followed up by general practitioners participated in the study. All of the patients met American Thoracic Society criteria for the diagnosis of COPD ${ }^{31}$. Inclusion criteria for patients with COPD included stable airflow limitation with an FEV ${ }_{1}$ of less than $70 \%$ predicted with reversibility of less than $11 \%$ predicted FEV, or less than $200 \mathrm{ml}$ after inhaled B-agonist administration and a previous history of at least 20 packyears of smoking. Six subjects with COPD were ex-smokers who had quit smoking for at least 1 year before the start of the study. Regular use of inhaled steroids was considered as an exclusion criterion for participation to the study: none of the studied patients with COPD therefore used inhaled steroids. Thirteen patients were prescribed combination therapy (fenoterol/ipratropiumbromide) on a regular basis. Two patients were on long-acting B2-agonists, and all other patients were prescribed bronchodilating agents on demand. Furthermore, a history of respiratory diseases other than COPD as well as increased respiratory complaints or respiratory tract infection during 4 weeks preceding the study was considered a criterion for exclusion. A control group of so-called healthy smokers was recruited that consisted of 17 subjects with a normal $\mathrm{FEV}_{1}$ and no medical history of lung disease. A smoking history of at least 15 pack-years was used as criterion for inclusion. Seven control subjects were ex-smokers. The control subjects lived in the same geographic area as the patient population. The study was approved by the medical ethics committee of the University Hospital of Maastricht. Written informed consent was obtained from all subjects.

\section{Pulmonary function test and blood sampling}

$\mathrm{FEV}_{1}$ was measured by trained lung function technicians using a spirometer (Masterlab; Jaeger, Würzburg, Germany) before and 15 minutes after inhalation of $B$-agonist via a metered-dose inhaler. Blood samples were collected in evacuated blood collecting tubes containing ethylenediaminetetraacetic acid (EDTA; Sherwood Medical, St. Louis, MO) before sputum induction (8:00 to 10:00 A.M.). Plasma samples were stored at $-80^{\circ} \mathrm{C}$ until analyzed. 
Table 1. Characteristics of the sudy groups investigated ${ }^{*}$

\begin{tabular}{lccc}
\hline & $\begin{array}{c}\text { COPD } \\
(n=18)\end{array}$ & $\begin{array}{c}\text { Healthy Smokers } \\
(n=17)\end{array}$ & P Value \\
\hline Mean age, yr & $60.9 \pm 8.1$ & $54.6 \pm 6.9$ & 0.017 \\
Gender, M/F & $16 / 2$ & $6 / 11$ & 0.001 \\
Mean FEV $\%$ predicted & $55.5 \pm 14.3$ & $98.7 \pm 16.2$ & $<0.001$ \\
Pack-years & $47.9 \pm 28.0$ & $32.3 \pm 13.2$ & 0.045 \\
Current smoker & 12 & 10 & $\mathrm{NS}^{*}$ \\
Ex-smoker & 6 & 7 & $\mathrm{NS}^{*}$ \\
\hline
\end{tabular}

* Values are means $\pm \mathrm{SD}$; Student T-test; ${ }^{i}$ Chi-square test. $\mathrm{COPD}=$ chronic obstructive pulmonary disease; $M=$ male; $F=$ iemale; $F E V_{1}=$ forced expiratory volume in 1 second; pack-year = smoking 1 pack per day for 1 yearr; ex-smoker = quitting smoking for at least 1 year before the start of the study; NS $=$ not significant.

\section{Sputum induction and processing}

Sputum was induced after a procedure as reported elsewhere ${ }^{14}$. Briefly, subjects inhaled $3 \%$ hypertonic saline, nebulized via an ultrasonic nebulizer (NEB2000; TEFA-Portanje, Woerden, The Netherlands) during three 7-minute periods. Before expectoration, subjects were instructed to mouthwash thoroughly with saline solution to minimize saliva contamination. The collected sputum was pooled and kept at $4^{\circ} \mathrm{C}$ for not more than 2 hours before further processing.

The volume of the pooled sputum (without selection of sputum plugs) was recorded, and an equal volume of $0.2 \%$ dithiothreitol (DTT; Sputolysin; Calbiochem, La Jolla, CA) was added. The samples were then mixed gently by a vortex mixer and incubated for 20 minutes at room temperature to ensure complete homogenization. Cell-free supernatants were frozen at $-80^{\circ} \mathrm{C}$ until subsequent analysis. The total cell count and cell viability were assessed using a standard hemocytometer (Coulter Z1; Coulter Electronics, Mijdrecht, The Netherlands) and by trypan blue exclusion, respectively. Cytospins were stained according to the May-Grünwald Giemsa method. Differential cell counts were performed by one observer blinded to the clinical characteristics, counting 500 nucleated cells. The numbers of squamous epithelial cells were subtracted, and the differential cell counts were expressed as corrected percentages. A sample was considered adequate if the slides contained $15 \%$ or less squamous epithelial cells.

Table 2. Total and differential cell counts in patients with COPD and healthy smokers*

\begin{tabular}{|c|c|c|c|}
\hline & $\begin{array}{l}\text { COPD } \\
(n=18)\end{array}$ & $\begin{array}{l}\text { Healthy Smokers } \\
(n=17)\end{array}$ & p Value \\
\hline Total cell count, $10^{6}$ cells $/ \mathrm{ml}$ & $4.0 \pm 3.3$ & $4.0 \pm 4.1$ & NS \\
\hline Viability. \% & $90.3 \pm 7.8$ & $90.3 \pm 10.0$ & NS \\
\hline $\mathrm{AM}_{*} \%$ & $17.1 \pm 10.9$ & $36.1 \pm 15.9$ & $<0.001$ \\
\hline PMN, \% & $80.5 \pm 12.4$ & $62.4 \pm 16.4$ & 0.001 \\
\hline EOS, & $1.8 \pm 3.6$ & $0.7 \pm 1.0$ & NS \\
\hline Lym $\%$ & $0.7 \pm 1.2$ & $0.9 \pm 0.8$ & NS \\
\hline
\end{tabular}


Analysis of sTNF receptors, TNF- $\alpha$, and IL-8 levels in sputum and plasma STNF-R55 and sTNF-R75 assays. sTNF-R were measured in sputum supernatant and plasma using specific sandwich enzyme-linked immunosorbent assay (ELISA) as described ${ }^{32,33}$. Rabbit anti-human sTNF-R55 polyclonal antibody and murine antihuman sTNF-R75 monoclonal antibody (MR2-2) were used as coating antibodies. Assays for sTNF-R were not affected by presence of $\mathrm{TNF}^{33}$, indicating that total amounts of STNF-R55 and STNF-R75 (free and bound to TNF- $\alpha$ ) were measured. The lower detection limit was $60 \mathrm{pg} / \mathrm{ml}$ for STNF-R55 and $30 \mathrm{pg} / \mathrm{ml}$ for STNF-R75.

TNF- $\alpha$ assays. Levels of TNF- $\alpha$ were measured using (1) a specific sandwich ELISA as described previously $y^{34,35}$ that recognizes bioactive TNF- $\alpha$ with a lower detection limit of $15 \mathrm{pg} / \mathrm{ml}$ as well as by (2) a commercially available ELISA (HyCult Biotechnology BV, Uden, The Netherlands) that recognizes free TNF- $\alpha$ as well as TNF- $\alpha$ bound to STNF receptors (referred to as total TNF- $\alpha$ fraction; personal communication HyCult Biotechnology BV) with a lower limit of detection of $20 \mathrm{pg} / \mathrm{ml}$.

IL-8 assay. IL-8 levels were determined using specific sandwich ELISA as described by Bouma and colleagues ${ }^{36}$. The lower detection limit was $8 \mathrm{pg} / \mathrm{ml}$.

DTT effect. To study the effect of DTT on ELISA determination of the inflammatory mediators assessed, standard curves of appropriate recombinant proteins were incubated with $0.1 \%$ DTT (Sputolysin) under the same conditions as sputum samples during processing (20 minutes at room temperature). The presence of DTT resulted in less than $5 \%$ inhibition of the detection of STNF-R55 and IL- 8 by ELISA and less than $10 \%$ inhibition in case of sTNF-R75, bioactive TNF$\alpha$, and total TNF- $\alpha$ fraction, indicating that DTT has little or no effect on the assays used in this study (data not shown).

\section{Microvascular leakage}

Microvascular leakage was determined in each individual as follows: sputum albumin $(\mathrm{mg} / \mathrm{L}) / \mathrm{serum}$ albumin $(\mathrm{g} / \mathrm{L})$. The albumin concentration in sputum and plasma was measured using a newly developed ELISA. Immunomaxisorp plates (Nunc, Roskilde, Denmark) were coated overnight with albumin-specific monoclonal antibody 4D5 (HM17). Diluted plasma samples and a standard dilution series with human albumin (Sigma, St. Louis, MO) were added to the plate. Albumin was detected with a horseradish peroxidase-labeled polyclonal rabbit anti-human albumin immunoglobulin G (Cappel; Organon Teknika Corporation, West Chester, PA) followed by 3',5,5'-tetramethylbenzidine (Kirkegaard and Perry Lab, Gaithersburg, MD) as substrate. The lower detection limit was $10 \mathrm{ng} / \mathrm{ml}$. The presence of DTT resulted in a less than $5 \%$ inhibition of the detection of albumin by ELISA.

\section{Statistical analysis}

Results are presented as mean \pm SD for normally distributed variables and median (range) otherwise. Groups were compared by analysis of covariance adjusted for age, sex, or pack-years where appropriate. Nonparametric data were compared by the Mann-Whitney U test. The chi-square test was used to compare 
categorical variables. Correlations between parameters were evaluated using Pearson's rank correlation analysis (Statistical Package for the Social Sciences, version 10.0 for Windows; SPSS Inc., Chicago, IL). A p value of less than 0.05 denotes the presence of a significant statistical difference.

\section{RESULTS}

\section{Clinical characteristics}

Clinical characteristics of patients with COPD and healthy smokers are shown in Table 1. Patients with COPD had significant airflow limitation, whereas control subjects had normal $\mathrm{FEV}_{1}$ values (percentage predicted) according to the selection criteria.

\section{Sputum characteristics}

All subjects included in this study tolerated well the procedure of sputum induction, and an adequate specimen of sputum was collected in every participant. Induced sputum was analyzed for total and differential cell counts, as shown in Table 2. The total cell counts and cell viability in sputum were not different in patients with COPD versus healthy smokers. Neutrophils (percentage) were significantly higher in patients with COPD in comparison with control subjects, whereas macrophages (percentage) were significantly lower.

Table 3. Inflammatory mediators in sputum of patients with COPD and healthy smokers*

\begin{tabular}{|c|c|c|c|}
\hline & $\begin{array}{l}\text { COPD } \\
(n=18)\end{array}$ & $\begin{array}{c}\text { Healthy Smokers } \\
(n=17)\end{array}$ & p Value \\
\hline $\mathrm{IL-8}, \mathrm{ng} / \mathrm{ml}$ & $3.7(1.4-12.2)$ & $2.3(0.8-5.2)$ & 0.008 \\
\hline Bioactive TNF- $\alpha$, pg/ml & $<15^{*}$ & $<15^{*}$ & NS \\
\hline Total TNF $\alpha$ fraction, $\mathrm{pg} / \mathrm{ml}$ & $59(20-143)$ & $57(20-206)$ & NS \\
\hline sTNF-R55, pg/ml & $237(60-2,501)$ & $109(60-435)$ & 0.020 \\
\hline STNF $4 R 75, \mathrm{pg} / \mathrm{ml}$ & $70(30-911)$ & $77(30-256)$ & NS \\
\hline
\end{tabular}

* Data are presiented als median (range), "Mann-Whitney $U$ test; "Below the detection limit. COPD chronic obstructive pulmonary disease; $1 \mathrm{~L}-8=$ interleukin $-B_{i}$ TNF- $\alpha=$ tumor necrosis factor- $\alpha ; N S=$ not significant; sTNF $-R 55=$ soluble TNF receptor 55 ; sTNF-R75 $=$ soluble TNF receptor 75 .

In addition, levels of the neutrophil chemoattractants IL-8 and TNF- $\alpha$ were determined in the sputum supernatant. IL-8 levels were significantly elevated in patients with COPD compared with healthy smokers (Table 3) and were strongly correlated with the number of neutrophils in the COPD group, but not in the control group (Table 4). Concerning TNF- $\alpha$, both bioactive TNF- $\alpha$ and the total TNF- $\alpha$ fraction (free TNF- $\alpha$ and TNF- $\alpha$ bound to STNF receptors) were determined (Table 3). Bioactive TNF- $\alpha$ was not detected in sputum samples of either patients with COPD or healthy smokers. Using the assay for the total TNF- $\alpha$ fraction, low concentrations of TNF- $\alpha$ were detected, but total TNF- $\alpha$ in sputum was not significantly different between the two groups. 
Table 4. Correlations between sputum makkers in patients with COPD and healthy smokers

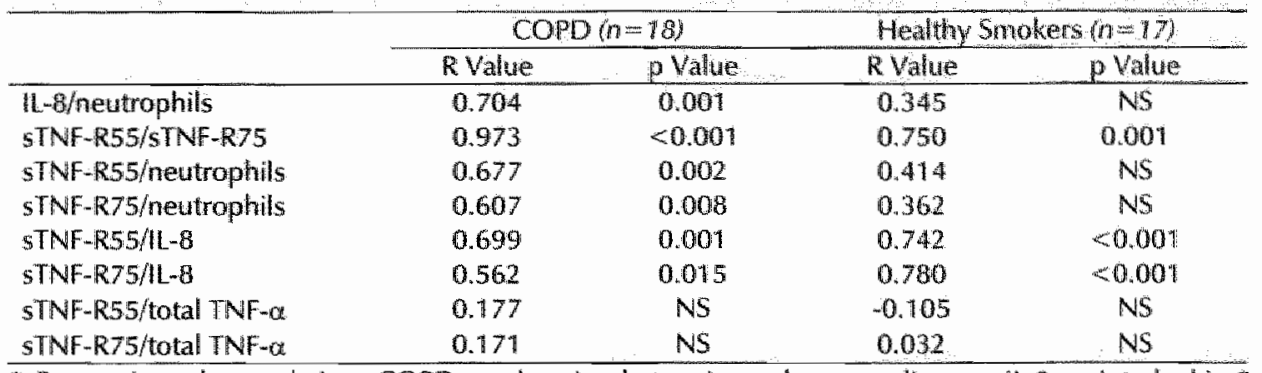

* Pearson's rank correlation. COPD = chronic obstructive pulmonary disease; IL-8 $=$ interleukin-8; sTNF-R55 = soluble TNF receptor $55 ;$ sTNF-R75 = soluble TNF receptor $75 ;$ TNF- $\alpha=$ tumor necrosis factor- $\alpha$; NS = not significant.

To characterize further the local inflammation in COPD, sputum levels of sTNF-R55 and STNF-R75 were determined. As shown in Table 3, both sTNF receptors were detectable in induced sputum of patients with COPD and healthy smokers. Sputum sTNF-R55 levels in patients with COPD patients showed a twofold increase as compared with healthy smokers. Sputum STNF-R75 levels showed a tendency to increase in patients with COPD, but did not reach the level of statistical significance $(p=0.08)$. As shown in Table 4 , sputum levels of sTNFR55 and STNF-R75 correlated highly with each other, and with IL-8 levels in both study groups. In contrast, sputum levels of the STNF receptors strongly correlated with the percentage of neutrophils in patients with $\mathrm{COPD}$, but this was not the case in healthy smokers. To address discrepancy, study groups were split according to the level of sputum neutrophils using the mean $+1 \times$ SD of sputum neutrophils in healthy controls as cutoff point. As shown in Figure 1, neutrophils (percentage) in sputum of 11 patients with COPD and 2 healthy smokers were out of the range of those found in healthy smokers. Furthermore, there was a large variance in sputum levels of sTNF-R55 and sTNF-R75 in patients with COPD with high neutrophil levels, whereas this was not the case in patients with COPD with low neutrophil levels.
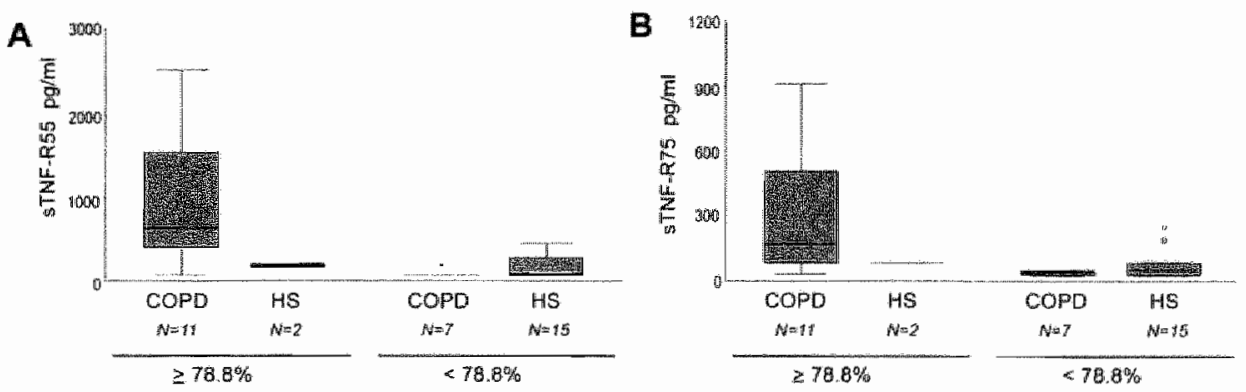

Figure 1. Levels of (A) STNF-R55 and (B) STNF-R75 in induced sputum obtained from patients with COPD and healthy smokers (HS). Study groups were split according to the level of sputum neutrophils using the mean $+1 \times 5 D$ of sputum neutrophits in healthy controls as cut-off point $(78.8 \%$ \%). The open circle symbolizes outhiers. 
Next, we investigated whether the pulmonary inflammation was related to the degree of airflow limitation. To this end, we looked for correlations between the FEV (percentage predicted) and sputum levels of IL-8, sTNF receptors; and TNFa. As shown in Figure 2, sputum levels of 1L-8 and sTNF-R55 strongly correlated with airflow limitation in patients with COPD but not in healthy smokers. Sputum STNF-R75 levels tended to correlate with the FEV in $_{1}$ patients with COPD, but this did not reach the level of statistical significance (STNF-R75, $r=-0.444, p=0.08$ ). The total TNF-a in sputum was not related to airflow limitation in patients with COPD $(r=-0.258, p=0.317)$.
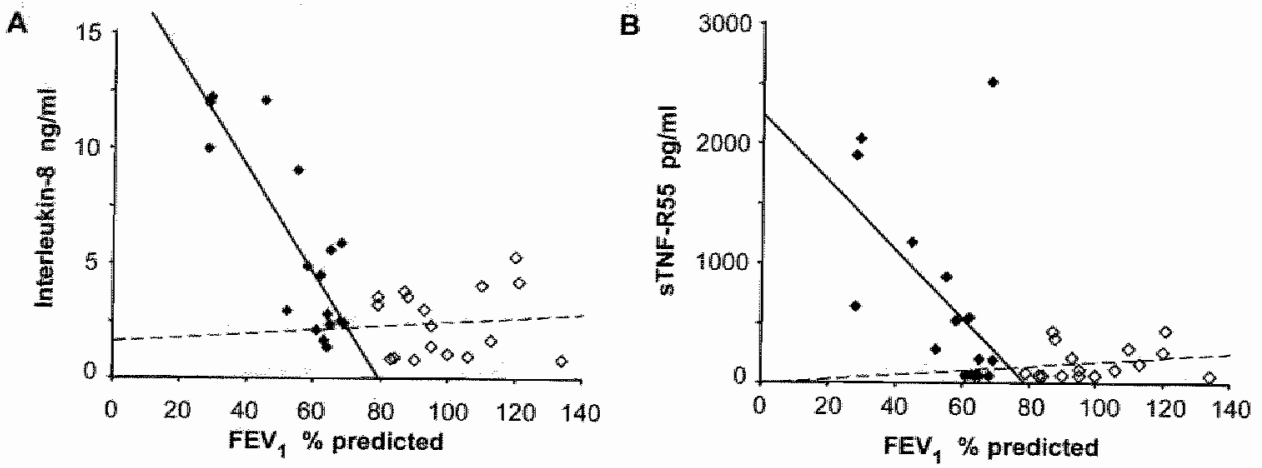

Figure 2. Correlation between the forced expiratory volume in 1 second ( $\left.F E V_{1}\right)$ and sputum levels of (A) IL.8 (COPD: $r=-0.836, p<0.001$; control: $r=0.093, p=0.723$ ) or (B) sTNF-R55 (COPD: $r=0.519$, $p=0.033$; control: $r=0.213, p=0.411$ ) in patients with COPD (closed diamonds) and healthy smokers (open diamonds).

\section{Plasma levels of sTNF receptors, TNF- $\alpha$, and IL-8}

Systemic inflammation was assessed by determination of plasma levels of sTNFR55, sTNF-R75, TNF- $\alpha$, and IL-8 by specific ELISA. As shown in Table 5, no significant difference was seen in circulating sTNF-R55 levels of patients with COPD and healthy control subjects. In contrast, plasma levels of STNF-R75 were significantly increased in patients with COPD. Like in sputum, plasma levels of STNF-R55 and STNF-R75 correlated highly with each other in both patients with COPD $(r=0.797, p<0.001)$ and healthy smokers $(r=0.732, p=0.001)$. IL-8 was detectable in 4 out of 18 patients with COPD in comparison with none of the 17 control subjects, resulting in significantly increased levels of $\| L-8$ in the COPD group. Circulating TNF- $\alpha$ was measured using the assay for total TNF- $\alpha$. Plasma TNF- $\alpha$ levels of all individuals except two were below the lower detection limit of the assay.

In addition, we investigated whether the systemic inflammation was related to the degree of airflow limitation by analyzing correlations between the FEV, (percentage predicted) and plasma levels of IL-8 and STNF receptors. In contrast to inflammatory mediators in sputum, circulating levels of the STNF receptors and IL-8 did not show any correlation with the degree of airflow limitation (data not 
Table 5. Inflammatory mediators in plasma of patients with COPD and healthy snokers*

\begin{tabular}{|c|c|c|c|c|c|}
\hline & & $\begin{array}{l}\text { COPD } \\
(n=18)\end{array}$ & & $\begin{array}{l}\text { Healthy Smokers } \\
\qquad(n=17)\end{array}$ & \& Value \\
\hline sTNF-R55, $\mathrm{ng} / \mathrm{ml}$ & & $2.0(1.4-3.3)$ & & $4.7(1.2-2.6)$ & NS \\
\hline STNF-R75, $\mathrm{ng} / \mathrm{ml}$ & & $1.9(1.3-2.9)$ & & $1.4(1.1-2.7)$ & 0.004 \\
\hline Total TNF-o, $\mathrm{pg} / \mathrm{m}$ & $n=y z$ & $<20^{\circ}$ & $a=15$ & $<20^{\circ}$ & NS \\
\hline & $n=1$ & 36.6 & $a=1$ & 34.9 & \\
\hline$\|\mathrm{L}-8, \mathrm{pg} / \mathrm{m}\|$ & $\begin{array}{l}n=14 \\
n=4\end{array}$ & $\begin{array}{c}<8.0^{*} \\
90<4^{\circ}\end{array}$ & $n=16$ & $<8.0^{*}$ & 0.049 \\
\hline
\end{tabular}

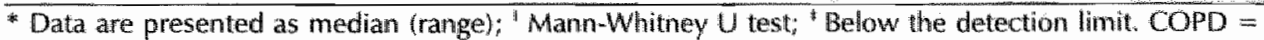
chronic obstructive pulmonary disease; $/ L-8=$ interleukin- 8 ; NS $=$ not significant; sTNF-R55 = soluble TNF receptor $55 ; \mathrm{sTNF}-\mathrm{R} 75=$ soluble TNF receptor $75 ; \mathrm{TNF}-\alpha=$ tumor necrosis factor-a.

\section{Relationship between local and systemic compartment}

To investigate the possible relationship between local and systemic inflammation in patients with COPD, we first determined to what extent the data are affected by microvascular leakage. To this end, we measured albumin levels in sputum and plasma of patients with COPD and healthy smokers and calculated the level of microvascular leakage in each individual as follows: sputum albumin ( $\mathrm{mg} / \mathrm{L}) / \mathrm{serum}$ albumin $(\mathrm{g} / \mathrm{L})$. Sputum-to-plasma ratios of albumin were not significantly different between the two study groups (median [range] COPD, $1.68[0.41-6.11]$; control, $1.31[0.29-4.00], p>0.05$ ), indicating a similar degree of microvascular leakage in patients with COPD and healthy smokers. Therefore, the values of the inflammatory mediators in sputum were not corrected for microvascular leakage.

Next, we looked for correlations between sputum and plasma levels of sTNFR55, sTNF-R75, and IL-8 in patients with COPD and healthy smokers to examine the relationship between local and systemic inflammation. As shown in Table 6, no direct correlations were found between sputum and plasma concentrations of each inflammatory mediator analyzed in either patients with COPD or in healthy smokers.

Table 6. Correlations between sputum and plasma levels of inflammatory mediators in patients with COPD and healthy smokers*

\begin{tabular}{lcccc}
\hline & \multicolumn{2}{c}{ COPD $(n=18)$} & \multicolumn{2}{c}{ Healthy Smokers $(n=16)$} \\
\cline { 2 - 5 } Sputum to plasma & R Value & p Value & R Value & Value \\
\hline STNF-R55 & 0.155 & 0.539 & 0.359 & 0.172 \\
STNF-R75 & 0.068 & 0.788 & 0.377 & 0.150 \\
IL-8 & 0.292 & 0.240 & - & -
\end{tabular}

* Pearson's rank correlation. $\mathrm{COPD}=$ chronic obstructive pulmonary disease; $1 \mathrm{~L}-\mathrm{B}=$ interleukin- $8 ; \mathrm{NS}$ $=$ not significant; sTNF-R55 = soluble TNF receptor 55 ; sTNF-R75 = soluble TNF receptor 75; TNF $=$ tumor necrosis factor.

\section{Local and systemic inflammation in current smokers versus ex-smokers}

To investigate the effect of smoking cessation on the local and systemic level of inflammation, subjects in both groups were divided according to their current smoking status, and levels of inflammatory mediators were compared between current and ex-smoking individuals. As shown in Table 7, sputum levels of sTNFR55, STNF-R75, and IL-8 were not different between current and ex-smokers in 
the control group. On the other hand, sputum levels of sTNF-R55, sTNF-R75, and IL-8 were significantly increased in patients with COPD who are ex-smokers compared with currently smoking patients with COPD. In addition, sTNF-R55 and IL-8 levels in sputum from ex-smoking patients with COPD were also significantly raised in comparison with ex-smoking healthy subjects, whereas sTNF-R75 levels showed a tendency to increase in ex-smoking patients with COPD $(p=0.09)$. In contrast, circulating levels of all inflammatory mediators assessed were not different in current smokers compared with ex-smokers in both study groups.

Table 7. Levels of soluble TNF-RS5, TNF-R75, and LL-8 in current smokers versus ex-Smokers*

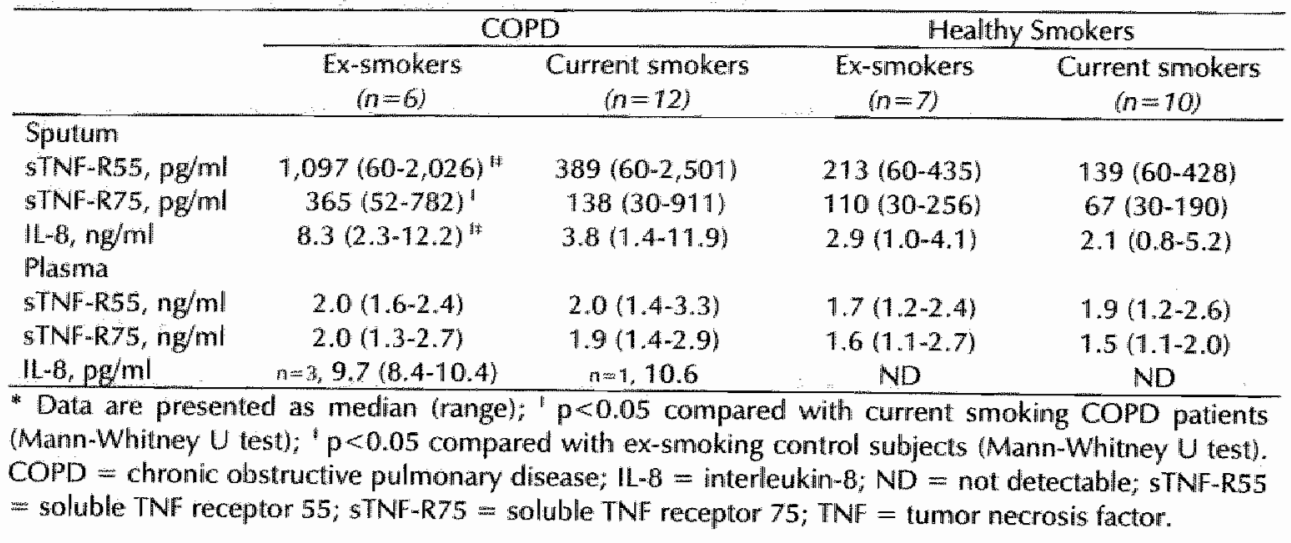

\section{DISCUSSION}

This study focused on the relationship between local and systemic inflammation in patients with mild-to-moderate smoking-related COPD. Analysis of induced sputum showed a significant increase in neutrophils (percentage) and IL-8 levels in patients with COPD versus healthy smokers, which correlated highly with each other and with the degree of airflow limitation. These findings are in line with previous observations in patients with COPD $^{1,14,16,17}$. Concerning TNF- $\alpha$, we found no significant differences in sputum TNF- $\alpha$ levels between mild-tomoderate patients with COPD and healthy smokers using either an ELISA that measures strictly intact TNF- $\alpha$ that is not bound by TNF receptors or using an ELISA that detects the total TNF- $\alpha$ fraction, that is, free TNF- $\alpha$ and TNF- $\alpha$ bound to STNF-R. In contrast, Keatings and colleagues reported a rise in TNF- $\alpha$ levels in induced sputum of patients with severe COPD ${ }^{14}$. This discrepancy may be due to differences in severity of COPD in the two patient populations studied or to differences between the characteristics of the TNF- $\alpha$ assays used. In addition, study populations may differ in rates of bacterial colonization, which was demonstrated to result in higher TNF- $\alpha$ levels in spontaneously expectorated sputum from Haemophilus influenzae-colonized patients with COPD in comparison with noncolonized but otherwise similar patients with COPD ${ }^{37}$. 
Finally, neutrophil elastase that is present in neutrophil microenwironment in induced sputum of patients with COPD is a potential parameter in the degradation of TNF- $\alpha$ into bioinactive TNF- $\alpha^{38}$, which may hamper the detection of bioactive TNF-a in sputum.

Soluble receptors for $T N F-\alpha$ are considered to be markers of a proinflammatory state because of their shedding from the cell membrane in response to endogenous TNF- $\alpha$ and other inflammatory mediators. In this study, we showed that in particular STNF-R55 was increased in induced sputum of patients with mild-to-moderate COPD compared with healthy smokers, which correlated with airflow limitation as well as other inflammatory markers (IL-8 and neutrophilia) in patients with COPD. Especially, respiratory epitheliall cells are reported to express TNF-R55 $5^{22}$ and may therefore account significantly for the increased levels of sTNF-R55 in sputum. In addition, in vitro studies by Porteu and Nathan demonstrated that activation of neutrophils resulted in shedding of both sTNF receptors from the cell surface, which suggests that STNF-R55 and sTNF-R75 measured in sputum may also be derived from activated neutrophils that are extensively present in sputum of patients with COPD ${ }^{39}$.

Previous studies from our group as well as other groups investigating systemic inflammation in patients with COPD demonstrated small but significant increases in plasma levels of STNF-R55 and STNF-R75 in patients with COPD in addition to enhanced levels of acute-phase proteins ${ }^{24-28}$. In line with these reports, we demonstrated that circulating STNF-R75 levels were elevated in patients with COPD as compared with healthy smokers. The biologic significance in the sense of the role that such a difference plays in the biologic phenomenon is not clear from these studies. sTNF receptors are known to compete for TNF- $\alpha$ with the cell surface TNF receptors and may hereby play a role in regulating steady-state levels of TNF- $\alpha$ in the airways and circulation ${ }^{40}$. Further studies using large study populations are necessary to elucidate the origin of STNF receptors and their function - either pro-inflammatory or anti-inflammatory - in chronic inflammation in COPD.

Although it is generally accepted that systemic inflammation contributes to the impaired health status in COPD, little is known about the origin of the systemic inflammation. Therefore, we assessed the possible relationship between the local and systemic inflammatory response. First, results of this study showed that patients with COPD had increased levels of STNF-R55 levels in sputum as compared with healthy smokers, whereas the reverse situation occurred in plasma: levels of STNF-R75 were higher in patients with COPD than in control subjects. Second, we found no correlation between the individual inflammatory mediators in sputum compared with plasma in both study groups. Furthermore, sputum levels of STNF-R55 and STNF-R75 were related with degree of airflow limitation in the COPD group, whereas plasma levels of sTNF receptors were not. Taken together, these results suggest that systemic inflammation in COPD is not due to an overflow of inflammatory mediators from the local compartment but that the inflammatory responses in the local and systemic compartment are differently regulated. In line with this hypothesis, Takabatake and colleagues 
recently reported that systemic hypoxia observed in patients with COPD due to deterioration of the lung function might contribute to enhanced levels of systemic inflammatory markers ${ }^{27}$. Future studies are clearly required to elucidate the origin and regulation of the systemic inflammatory response in COPD.

Cigarette smoking is widely recognized as a primary risk factor for developing COPD in industrialized countries. The presence of harmful compounds in inhaled cigarette smoke, including endotoxin ${ }^{41}$, is considered to be the starting point of the pathogenetic pathway in COPD. Previous studies have shown that smoking cessation resulted in a significant reduction of the age-related decline in $\mathrm{FEV}_{7}{ }^{2-4}$. However, a longitudinal follow-up study of smoking-induced lung density changes by high-resolution computed tomography demonstrated that the worsening airspace abnormality in the upper lung zones of smokers did not slow down with cessation of smoking ${ }^{42}$. In addition, other studies investigating airway inflammation reported that smoking cessation did not influence the cellular profile and levels of IL-8 in central and peripheral airways ${ }^{16,43-45}$. In this study, we found a remarkable increase in sputum levels of STNF-R55, sTNF-R75, and IL-8 in exsmoking patients with COPD compared with currently smoking patients with COPD, but not in ex-smoking versus currently smoking healthy controls. In addition, sputum levels of sTNF-R55 and IL-8 in ex-smoking patients with COPD were also significantly raised in comparison with levels in ex-smoking healthy subjects. In contrast, the systemic proinflammatory state was not associated with the smoking status in both study groups. Our results are strongly supported by the recently reported data of Willemse and colleagues ${ }^{46}$, who collected induced sputum before and 1 year after smoking cessation in smokers with COPD and without COPD. They showed that $1 \mathrm{~L}-8$ levels in sputum decreased without changes in sputum neutrophils after 1 year of smoking cessation in smokers without COPD. In contrast, in smokers with COPD, levels of IL-8 and neutrophils in sputum tended to increase $(\mathrm{p}<0.1)$. Taken together, these data suggest an ongoing inflammatory response in the respiratory compartment of patients with COPD after smoking cessation.

In summary, patients with COPD had significantly higher percentages of neutrophils and increased levels of STNF-R55 and IL-8 in their induced sputum samples as compared with healthy smokers. A comparison of sTNF receptors in sputum and plasma, however, did not demonstrate direct correlations between local and systemic inflammation, despite the significantly higher circulating levels of STNF-R75 in patients with COPD. Moreover, sputum STNF receptors were related with the degree of airflow limitation in patients with COPD, whereas circulating STNF receptors were not, suggesting different regulation of the inflammatory response in the local and systemic compartment. Sputum levels of STNF-R55, STNF-R75, and IL-8 were increased in ex-smoking versus currently smoking patients with COPD as well as ex-smoking control subjects, whereas the current smoking status was not associated with the systemic proinflammatory state in the study groups. These results confirm the presence of inflammatory processes in the airways and circulation of patients with COPD despite smoking cessation. 


\section{ACKNOWLEDGEMENTS}

The authors thank Dr. A.M.W.J. Schols for expert assistance with the statistical evaluation of the data and for critically reading the manuscript, and J. Cleven for developing the human albumin ELISA. This study was supported by a grant from Glaxo Wellcome, The Netherlands.

\section{REFERENCES}

1. Barnes PJ. Chronic obstructive pulmonary disease. N Engl I Med 2000;343:269-280.

2. Anthonisen NR, Connett JE, Kiley JP, Altose MD, Bailey WC, Buist AS, Conway WA, Jr., Enright $P L$, Kanner RE, OHara $P$, and et al. Effects of smoking intervention and the use of an inhalled anticholinergic bronchodilator on the rate of decline of FEV1. The Lung Health Study. Jama 1994;272:1497-1505.

3. Scanlon PD, Connett JE, Waller LA, Altose MD, Bailey WC, and Buist AS. Smoking cessation and lung function in mild-to-moderate chronic obstructive pulmonary disease. The Lung Health Study. Am I Respir Crit Care Med 2000;161:381-390.

4. Kanner RE, Connett JE, Williams DE, and Buist AS. Effects of randomized assignment to a simoking cessation intervention and changes in smoking habits on respiratory symptoms in smokers with early chronic obstructive pulmonary disease: the Lung Health Study. Am / Med 1999; 106:410-416.

5. Finkelstein $R$, Fraser RS, Ghezzo $H$, and Cosio MG. Alveolar inflammation and its relation to emphysema in smokers. Am / Respir Crit Care Med 1995;152:1666-1672.

6. Saetta M, Di Stefano A, Turato C, Facchini FM, Corbino L, Mapp CE, Maestrelli P, Claccia A, and Fabbri $\angle M$. CD8 + T-lymphocytes in peripheral airways of smokers with chronic obstructive pulmonary disease. Am / Respir Crit Care Med 1998;157:822-826.

7. Saetta $M_{p}$ Baraldo $S$, Corbino L, Turato $G_{x}$ Braccioni $F$, Rea $F_{n}$ Cavallesco $G_{n}$ Tropeano $G_{s}$ Mapp CE, Maestrelli P, Ciaccia A, and Fabbri LM. CD8+ve cells in the lungs of smokers with chronic obstructive pulmonary disease. Am / Respir Crit Care Med 1999;160:711-717.

8. Saetta $M_{*}$ Turato $G$, Baraldo $S$, Zanin A, Braccioni F, Mapp CE, Maestrelli $P_{*}$ Cavallesco G, Papi A, and Fabbri LM. Goblet cell hyperplasia and epithelial inflammation in peripheral airways of smokers with both symptoms of chronic bronchitis and chronic airfllow llimitation. Am I Respir Crit Care Med 2000;161:1016-1021.

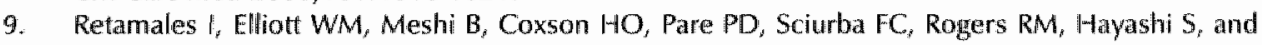
Hogg JC. Amplification of inflammation in emphysema and its association with latent adenowirat infection. Am J Respir Crit Care Med 2001;164:469-473.

10. Shapiro SD. End-stage chronic obstructive pulmonary disease: the cigarette is burned out but inflammation rages on. Am/ Respir Crit Care Med 2001; 164:339-340.

11. Peleman RA, Rytilla PH, Kips JC, Joos GF, and Pauwels RA. The cellular composition of induced sputum in chronic obstructive pulmonary disease. Eur Respir $\int$ 1999:13:8394843.

12. Pesci A, Balbi B, Majori M, Cacciani $G$, Bertacco S, Alciato P, and Donner CF. Inflammatory cells and mediators in bronchial lavage of patients with chronic obstructive pulmonary disease. Eur Respir J 1998;12:380-386.

13. Alexis NE, Hu SC, Zeman $K$, Alter $T$, and Bennett WD. Induced Sputum Derives from the Central Airways. Confirmation using a radiolabeled aerosol bolus delivery technique. Am / Respir Crit Care Med 2001;164:1964-1970.

14. Keatings VM, Collins PD, Scott DM, and Barnes PJ. Differences in interleukin-8 and tumor necrosis factor-alpha in induced sputum from patients with chronic obstructive pulmonary disease or asthma. Am/Respir Crit Care Med 1996;153:530-534.

15. Di Stefano A, Capelli $A$, Lusuardi $M$, Balbo P, Vecchio $C$, Maestrelli P, Mapp CE, Iabbri LM, Donner $C F$, and Saetta M. Severity of airlow limitation is associated with severify of airway inflammation in smokers. Am J Respir Crit Care Med 1998;158:1277-1285. 
16. Yamamoto $C$, Yoneda T, Yoshikawa M, Fu A, Tokuyama I, Tsukaguchi $K$, and Narita M. Ainway inflanmation in COPD assessed by sputum lewels of interlleulkin-3. Chest 1997;112:505-510.

17. kutgers SR, Timens W, Kaumann HF, van der Mark TW, Koeter CH, and Postma DS. Compuarison of induced sputum with bronchial wash, bronchoalveolar lavage and baronchial biopsies in COPD. Eur Respir / 2000; 15:109-115.

18. Keatings VM, and Barmes 1 J. Granulocyle actiwation markers in induced sputum: comparison between chronic obstructive pulmonary disease, asthma, and normal subjects. Am / Respir Crit Care Med 1997;155:449-453.

19. Betsuyaku T, Nishimura M, Takeyabu $K$, Tanino M, Venge $P$, Xu 5 , and Kawakami Y. Neutrophil granule proteins in bronchoalveolar lavage fluid from subjects with subclinical emphysema. Am I Respir Crit Care Med 1999; $159: 1985-1991$.

20. Aderka D. The potential biological and clinical significance of the soluble tumor necrosis factor receptors. Cytokine Growth Factor Rev 1996:7:231-240.

21. Brockhaus $M$, Schoenfeld HI, Schlaeger $E$, Hunzker W', Lesslauer $W$, and Loetscher H. Identificaltion of two types of tumor necrosis factor receptors on human cell lines by monoclonal antibodies. Proc Nat' Acad Sci U S A 1990;87:3127-3131.

22. Pryhuber GS, Huyck HL, Staversky RJ, Finkelstein JN, and OReilly MA. Tumor necrosis factoralpha indiced lung cell expression of antiapoptotic genes TRAF1 and CIAP2. Am / Respir Cell Mol Biol $2000 ; 22 ; 150-156$.

23. Lantz M, Malik S, Slevin ML, and Olsson 1. Infusion of tumor mecrosis factor (TNF) causes an increase in circulating TNF-binding protein in humans. Cytokine 1990:2:402-406.

24. Schols AM, Burman WA, Stal wan den Brekel A., Dentener MA, and Wouters EF. Evidence for a relation between metabolic derangements and increased levels of inflammatory mediators in a subgroup of patients with chronic obstructive pulmonary disease. Thorax 1996; 51:819-824.

25. Dentener MA, Creutzberg EC, Schols AM, Mantowani A, vant Veer C, Buurman WA, and Wouters EF. Systemic anti-inflammatory mediators in COPD: increase in soluble interleukin "I receptor II during treatment of exacerbations. Thorax 2001;:56:721-726.

26. Takabatake $N$, Nakamura $H$, Abe $S$, Hino $T$, Saito $H$, Yuki $H$, Kato $S$, and Tomoike $H$. Circulating leptin in patients with chronic obstructive pulmonary disease. Am / Respir Crit Care Med $1999 ; 159: 1215-1219$.

27. Takabatake $N$, Nakamura H, Abe $S$, Inowe $S$, Hino T, Saito H, Vuki H, Kato $S_{\text {, }}$ and Tomolke H. The relationship between chronic hypoxemia and activation of the tumor necrosis factor-alpha system in patients with chronic obstructive pulmonary disease. Am J Respir Crit Care Med $2000 ; 161 ; 1179-1184$.

28. Eid AA, lonescu AA, Nixon LS, Lewis-jenkins $V$, Matthews SB, Griffiths TL, and Shale DI. Inflammatory response and body composition in chronic obsteuctive pumonary disease. Am J Respir Crit Care Med 2001;164:1414-1418.

29. Di Francia $M$, Barbier $\mathrm{D}$, Mege $\mathrm{JL}$ and Orehek $\mathrm{J}$. Tumor necrosis factor-alpha levels and weight loss in chronic obstructive pulmonary disease. Am / Respir Crit Care Med 1994;150:1453-1455.

30. De Codoy \#, Donahoe $M$, Cahoun WJ, Mancino ), and Rogers RM. Ellevated TNFalpha production by peripheral blood monocytes of weight-losing COPD patients. Am / Respir Crit Care Med 1996:153:633-637.

31. ATS. Standards for the diagnosis and care of pathents with chronic obstructive pulmonary disease. Am I Respir Crit Care Med 1995;152:577-121.

32. Leeuwenberg IF, Dentener MA, and Butrman WA Lipopolysaccharide LPS-mediated soluble TNF receptor release and TNF receptor expression by monocytes. Role of CD14, LPS binding protein. and bactericidal/penmeability-increasing protein. I /mmunol 1994; 152:5070-5076.

33. Leeuwenberg $J F$, Jeumhomme TM, and Buurman WA. Slow release of soluble TNF recepitors by monocytes in vitro. / Immunol 1994:152:4036-4043.

34. Engelberts 1, Stephens S, Francot Gl, van der Linden $C$, and Buurman WA. Evidence for different effects of soluble TNF-receptors on various TNF measurements in human biological fulds. Lancet $1991: 338: 515-516$

35. Engelberts 1: Moller A, Schoen GJ, van der Linden Cl, and Buurman WA. Evaluation of measurement of human TNF in plasma by ELISA. Lymphokine Cytokine Res 1991;10:69-76.

36. Bouma $M G$, Stad RK, van den Wildenberg FA, and Bunman WA. Differential regulatory effects of adenosine on cytokine release by actiwated human monocytes. I Innunol 1994;153:4159-4168. 
37. Bresser $P$, Out $T A_{s}$ van Alphen $L$, Jansen $H M$, and Lutter $R$. Airway inflammation in nonobsitructive and obstructive chronic bronchitis with chronic haemophilus influenzate ainway infection. Comparison with noninfected patients with chronic obstructive pulmonary disease. An J Respir Crit Care Med 2000;162:947-952.

38. Nortier $\mathbb{N}$, Vandenabeele $\mathbb{P}$, Noel $E$, Bosseloir $Y$, Goldman $M$, and Deschodt-lanckman $M$. Enzymatic degradation of tumor necrosis factor by activated human neutrophils: role of elastase. Life Sci 1991; 49:1879-1886.

39. Porteu $F$, and Nathan $C$. Shedding of tumor necrosis factor receptors by activated human neutrophils. / Exp Med 1990;172:599-607.

40. Pinckard $\mathrm{K}$, Sheehan $\mathrm{KC}$, Arthur $\mathrm{CD}$, and Schreiber RD. Constitutive shedding of both $\mathrm{p} 55$ and p75 murine TNF receptors in vivo. / Immunol 1997;158:3869-3873.

41. Hasday JD, Bascom R, Costa J), Fitzgerald $T$, and Dubin W. Bacterial endotoxin is an active component of cigarette smoke. Chest 1999:115:829-835.

42. Soejima $K$, Yamaguchi $K$, Kohda $E$, Takeshita $K_{2}$ Ito $Y$, Mastubara $H$, Oguma $T$, Inove $T$, Okubo $Y$,

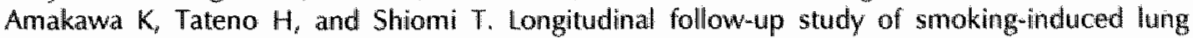
density changes by high-resolution computed tomography. Am / Respir Crit Care Med 2000; 161:1264-1273.

43. Mullen JB, Wright JL, Wiggs $B R_{t}$, Pare PD, and Hogg JC. Structure of central airways in current smokers and ex-smokers with and without mucus hypersecretion: relationship to lung function. Thorax 1987:42:843-848.

44. Turato $G$, Di Stefano $A$, Maestrelli P, Mapp CE, Ruggieri MP, Roggeri A, Fabbri LM, and Saetta $M$. Effect of smoking cessation on airway inflammation in chronic bronchitis. Am / Respir Crit Care Med 1995;152:1262-1267.

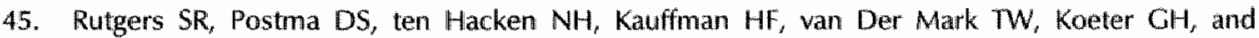
Timens W. Ongoing airway inflammation in patients with COPD who do not currently smoke. Thorax 2000;55:12-18.

46. Willemse BW, Ten Hacken NH, Rutgers B, G. LI, Postma DS, and Timens W. The effect of one year smoking cessation on neutrophilic inflammation in smokers with and without COPD. Am I Respir Crit Care Med 2002;165:A463. 


\title{
CHAPTER 4
}

\section{Local and systemic acute-phase response in COPD}

\author{
Juanita H.J. Vernooy', Mieke A. Dentener', Wim A. Buurman', and \\ Emiel F.M. Wouters'
}

Departments of ${ }^{1}$ Respiratory Medicine and ${ }^{2}$ General Surgery, University Hospital Maastricht, Maastricht, The Netherlands

\author{
Submitted
}

\begin{abstract}
Introduction: Acute-phase reactants (APRs) play an important role in innate immunity. As expression of APRs in the airways may enhance local response to injury and infection in COPD, this study aimed to assess levels of $\alpha_{1}$-acid glycoprotein (AGP), lipopolysaccharide-binding protein (LBP), and C-reactive protein (CRP) in induced sputum of COPD patients and healthy smokers. Methods: Sputum induction was performed in 18 patients with COPD (FEV $158 \%$ predicted) and 17 healthy smokers (FEV $199 \%$ predicted). AGP, LBP, and CRP were analyzed in sputum supernatant and plasma by ELISA. Results: AGP, LBP, and CRP were present in sputum of all subjects. Sputum levels of AGP and LBP were significantly increased in COPD patients versus healthy smokers, and inversely correlated with the FEV, values in COPD. In contrast, sputum CRP was not different between the study groups. In plasma, LBP was markedly elevated in COPD patients versus healthy smokers, whereas circulating levels of AGP and CRP tended to be increased in COPD. In contrast to sputum, AGP and LBP in plasma were positively related to the FEV, values. When APRs in sputum and plasma were compared, no direct relations were found despite that APRs were strongly related with each other in each compartment. Conclusion: AGP and LBP were significantly increased in sputum of COPD patients, which may be due to local production rather than leakage from the systemic compartment.
\end{abstract}




\section{INTRODUCTION}

The acute-phase response is a coordinated series of physiological and biochemical changes executed by the host, and thought to be beneficial with the aim of restoring the disturbed physiological homeostasis and preventing ongoing tissue damage. Substantial changes in plasma acute-phase reactants (APRs) are commonly obsened during acute infection, trauma, surgery, and burns. On the other hand, small but significant elevations in systemic APRs are strongly associated with chronic inflammatory disorders. For example, we and others have demonstrated that patients suffering from chronic obstructive pulmonary disease (COPD) have increased plasma levels of C-reactive protein (CRP), lipopolysaccharide-binding protein (LBP), and fibrinogen ${ }^{4-3}$, accompanied by a rise in the acute-phase cytokines interleukin-6 ( $(\mathbb{L}-6)$ and tumor necrosis factor- $\alpha(\text { TNF- } \alpha)^{4,5}$. In addition, elevated levels of APRs are noted in rheumatoid arthritis, inflammatory bowel disease, cardiovascular diseases, and obesitas.

The nature of APRs, which include protease inhibitors, complement proteins, and proteins that can bind to endotoxin, suggest an important role in innate immunity and reduction of inflammatory reactions. In this view, expression of APRs in the respiratory system, which is continuously exposed to numerous potentially harmful agents via the air inhaled, may enhance the early phase of specific local responses to injury and infection. In line with this hypothesis, there is a growing body of evidence for extra-hepatic expression of APRs. We and others previously demonstrated that human primary type II alveolar cells as well as respiratory cell lines derived from type II pneumocytes are able to produce LBP, $\alpha_{1}$-acid glycoprotein (AGP) and fibrinogen ${ }^{6-q}$. In addition, increased expression of CRP, AGP, and fibrinogen was reported after in vitro stimulation of alveolar macrophages 9.10 . In vivo, increased BALF levels of AGP, LBP and fibrinogen were demonstrated in patients suffering from asthma ${ }^{11,12}$ and ARDS $^{13}$. In addition, CRP detected in sputum of chronic bronchitis patients was shown to have anti-bactericidal activities in vitro ${ }^{14}$.

Chronic airway inflammation is considered to be a hallmark of COPD. Previous studies showed profound neutrophilia and increased levels of IL-8, TNF- $a$ and soluble TNF-receptors in sputum of COPD patients versus healthy smokers, which correlated highly with each other and the degree of airflow limitation ${ }^{15,16}$. As expression of APRs in the airways may enhance the early phase of specific local responses to injury and infection in COPD, the present study aims to assess levels of AGP, LBP, and CRP in induced sputum of well-characterized COPD patients and healthy smokers ${ }^{16}$. In addition, the relation between levels of APRs in induced sputum and plasma as indicator of the relationship between local and systemic acute-phase response was investigated.

\section{MATERIAL \& METHODS}

Subjects

Eighteen patients with smoke-related, clinically stable COPD participated in the study. 
All of the COPD patients met the American Thoracic Society (ATS) criteria for the diagnosis of $\mathrm{COPD}^{17}$. Inclusion criteria for COPD patients included stable airflow limitation with an FEV, of less than $70 \%$ predicted with reversibility of less than $11 \%$ predicted $\mathrm{FEV}_{1}$ or less than $200 \mathrm{ml}$ after inhaled $\beta 2$-agonist administration and a previous history of at least 20 pack-years of smoking. Thirteen patients were prescribed combination therapy (fenoterol/ipratropiumbromide) on a regular base, two patients were on long-acting $\beta_{2}$-agonists and all other patients were prescribed bronchodilating agents on demand. Regular use of inhaled steroids, a history of respiratory diseases other than COPD, and increased respiratory complaints or respiratory tract infection during 4 weeks preceding the study were considered as criteria for exclusion.

A control group of so-called healthy smokers was recruited that consisted of 17 subjects with a normal FEV, and no medical history of lung disease. A smoking history of at least 15 pack-years was used as criterium for inclusion. The control subjects lived in the same geographic area as the patient population. The study was approved by the medical ethics committee of the University Hospital of Maastricht. Written informed consent was obtained from all subjects.

\section{Pulmonary function test and blood sampling}

FEV 1 was measured by trained lung function technicians using a spirometer (Masterlab, Jaeger, Würzburg, Germany) before and 15 min after inhalation of $\beta$ agonist via a metered-dose inhaler. Blood samples were collected in evacuated blood collecting tubes containing ethylene-diaminetetraacetic acid (EDTA; Sherwood Medical, St. Louis, MO) before sputum induction ( $8.00-10.00$ AM). Plasma samples were stored at $-80^{\circ} \mathrm{C}$ until analyzed.

\section{Sputum induction and processing}

Sputum was induced after a procedure as reported previously ${ }^{15}$. Briefly, subjects inhaled $3 \%$ hypertonic saline, nebulized via an ultrasonic nebulizer (NEB2000, TEFAPortanje, Woerden, The Netherlands) during three 7 -mim periods. Before expectoration, subjects were instructed to mouthwash thoroughly with saline solution to minimize saliva contamination. The collected sputum was pooled and kept at $4{ }^{\circ} \mathrm{C}$ for not more than 2 hours prior to further processing.

The volume of the pooled sputum (without selection of sputum plugs) was recorded, and an equal volume of $0.2 \%$ dithiothreitol (DTT; Sputolysin; Calbiochem, La Jolla, CA) was added. The samples were then mixed gently by a vortex mixer and incubated for $20 \mathrm{~min}$ at room temperature to ensure complete homogenization. Cell. free supernatants were frozen at $-80^{\circ} \mathrm{C}$ until subsequent analysis. The total cell count and cell viability were assessed using a standard haemocytometer (Coulter Z $Z$, Coulter Electronics, Mijdrecht, The Netherlands) and by trypan blue exclusion, respectively. Cytospins were stained according to the May-Grünwald-Giemsa method. Differential cell counts were carried out by one observer blinded to the clinical characteristics, counting 500 nucleated cells. The numbers of squamous cells were substracted, and the differential cell counts were expressed as corrected percentages. A sample was considered adequate if the slides contained $15 \%$ or less 
squamous epithelial cells.

Analysis of acute-phase reactants and inflammatory mediators in sputum and plasma Acute-phase reactants. $\mathrm{LBP}, \mathrm{AGP}$, and CRP were measured in sputum supernatant and plasma using specific sandwich enzyme-linked immunosorbent assay (ELISA) as reported previously. Briefly, LBP was detected using polyclonal rabbit anti-rhLBP IgC as coating and biotin-labeled polyclonal rabbit anti-rhLBP IgG for detection ${ }^{18}$. For ACP measurement, plates were coated with polyclonal rabbit anti-hACP and detection was carried out with a biotinylated polyclonal rabbit anti-hAGP $\mathrm{P}^{19}$. The CRP concentration was measured by a polyclonal ELISA for which antibodies and standard were obtained from Dako $\mathrm{A} / \mathrm{S}$ (Glostrup, Denmark) ${ }^{19}$. The lower detection limit was $1 \mathrm{ng} / \mathrm{ml}$ for LBP, $100 \mathrm{pg} / \mathrm{ml}$ for ACP, and $100 \mathrm{pg} / \mathrm{ml}$ for CRP.

Inflammatory mediators. Levels of IL-8 and IL-6 were measured using specific sandwich ELISA as described previousl $\mathrm{y}^{20,24}$. The lower detection limit was $8 \mathrm{pg} / \mathrm{ml}$ for $\| \mathrm{L}-8$ and $10 \mathrm{pg} / \mathrm{ml}$ for IL-6. All sputum and plasma samples were analyzed in the same run. When sputum or plasma concentrations exceeded the upper detection limit of the assay, samples were additionally diluted and analyzed in a separate run with an overlap to correct for inter-assay variation. The intra- and inter-assay coefficients of variance of the various assays were all $<10 \%$.

DTT effect. To study the effect of DTT on ELISA determination of the mediators assessed, standard curves of appropriate recombinant proteins were incubated with $0.1 \%$ DTT (Sputolysin) under the same conditions as sputum samples during processing (20 min at room temperature). The presence of DT resulted in less that $5 \%$ inhibition of the detection of AGP, CRP, IL-6, and IL-8 by ELISA and less than $10 \%$ inhibition in case of LBP, indicating that DTT has little or no effect on the assays used in this study (data not shown).

\section{Microvascular leakage}

Microvascular leakage was determined in each individual as follows: sputum albumin $(\mathrm{mg} / \mathrm{L}) /$ serum albumin $(\mathrm{g} / \mathrm{L})$. Albumin concentration in sputum and plasma were measured by ELISA using monoclonal antibody 4D5 (HM17) as coating and HRPlabeled polyclonal rabbit anti-human albumin IgG for detection ${ }^{16}$ " The lower detection limit of the ELISA was $10 \mathrm{ng} / \mathrm{ml}$. Presence of DTT resulted in less than $5 \%$ inhibition of albumin detection by ELISA.

\section{Statistical analysis}

Results are presented as mean \pm standard deviation (SD) for normally distributed variables and median (range) otherwise. Groups were compared by analysis of covariance adjusted for age, gender, or pack-years where appropriate. Nonparametric data were compared by the Mann-Whitney U test. The chi-square test was used to compare categorical variables. Correlations between parameters were evaluated using Pearson's rank correlation analysis (Statistical Package for the Social Sciences, version 10.0 for Windows, SPSS Inc., Chicago, IL). A p-value of less than 0.05 denotes the presence of a significant statistical difference. 
Table 1. Characteristics of the study groups investigated *

\begin{tabular}{|c|c|c|c|}
\hline & $\begin{array}{c}C O P D \\
(n=18)\end{array}$ & $\begin{array}{l}\text { Healthy Smokers } \\
\qquad(n=17)\end{array}$ & p Value? \\
\hline Mean age, yr & $60.9 \pm 8.1$ & $54.6 \pm 6.9$ & 0.017 \\
\hline Gender, $M / F$ & $16 / 2$ & 641 & 0.001 \\
\hline Mean FEV ${ }_{1} \%$ predicted & $55.5 \pm 14.3$ & $98.7 \pm 16.2$ & $<0.001$ \\
\hline Pack-years & $47.9 \pm 28.0$ & $32.3 \pm 13.2$ & 0.045 \\
\hline Current smoker & 12 & 10 & NS \\
\hline Ex-smoker & 6 & 7 & $N S^{*}$ \\
\hline
\end{tabular}

* Values are means $\pm \mathrm{SD}_{j}{ }^{\prime}$ Student T-test ${ }^{*}$ Chi-square test. $\mathrm{COPD}=$ chronic obstructive pulmonany disease; $\mathrm{M}=$ malle; $\mathrm{F}=$ female; $\mathrm{FEV}_{1}=$ forced expiratory volume in 1 second; pack-year $=$ smoking 1 pack per day for 1 year; ex-smoker = quitting smoking for at least 1 year before the start of the study; NS $=$ not significant.

Table 2. Sputum characteristics*

\begin{tabular}{lccc}
\hline & $\begin{array}{c}\text { COPD } \\
(n=18)\end{array}$ & $\begin{array}{c}\text { Healthy Smokers } \\
(n=17)\end{array}$ & PValue \\
\hline Total cell count, $10^{\circ}$ cells/ml & $4.0 \pm 3.3$ & $4.0 \pm 4.1$ & $\mathrm{NS}$ \\
Viability, \% & $90.3 \pm 7.8$ & $90.3 \pm 10.0$ & $\mathrm{NS}$ \\
AM, \% & $17.1 \pm 10.9$ & $36.1 \pm 15.9$ & $<0.001$ \\
PMN, \% & $30.5 \pm 12.4$ & $62.4 \pm 16.4$ & 0.001 \\
Eos, \% & $1.8 \pm 3.6$ & $0.7 \pm 1.0$ & $\mathrm{NS}$ \\
Lym, \% & $0.7 \pm 1.2$ & $0.9 \pm 0.8$ & $\mathrm{NS}$ \\
IL-8, ng/ml & $3.7(1.4-12.2)$ & $2.3(0.8-5.2)$ & 0.008 \\
IL-6, ng/m\| & $0.34(0.16-1.26)$ & $0.35(0.15-1.43)$ & $\mathrm{NS}$ \\
\hline
\end{tabular}

* Data are presented as means \pm SD for cell counts and median (range) for interleukins; 'ANOVA adjusted for age, gender, and pack-years for cell counts and Mann-Whitney $U$ test for interleukins. COPD = chronic obstructive pulmonary disease; $A M=$ alveolar macrophages; PMN = neutrophills; Eos = eosinophils; $L y m$ $=$ lymphocytes: $\mathrm{IL}=$ interleukin; NS = not significant.

\section{RESULTS}

\section{Clinical characteristics}

Table 1 shows the clinical characteristics of COPD patients and healthy smokers. Patients with COPD had significant airflow limitation, whereas healthy smokers had normal $\mathrm{FEV}$, values (\% predicted) according to the selection criteria.

\section{Sputum characteristics}

All subjects included in this study tolerated well the procedure of sputum induction and an adequate specimen of sputum was collected in every participant. Sputum characteristics are shown in Table 2. Analysis of induced sputum showed a significant increase in neutrophils (\%) and IL-8 levels in COPD patients versus heal thy smokers, which highly correlated with each other $(r=0.704, p=0.001)$ in COPD patients, but not in healthy smokers. In addition, the degree of airflow limitation ( $F E V_{1} \%$ predicted) correlated strongly with both the percentage of neutrophils $\left(r=-0.576_{\text {, }}\right.$ $p=0.016)$ and IL-8 levels $(r=-0.836, p<0.001)$ in sputum of COPD patients, whereas no correlations were found in healthy smokers. In contrast to IL- $B_{t}$ levels of 

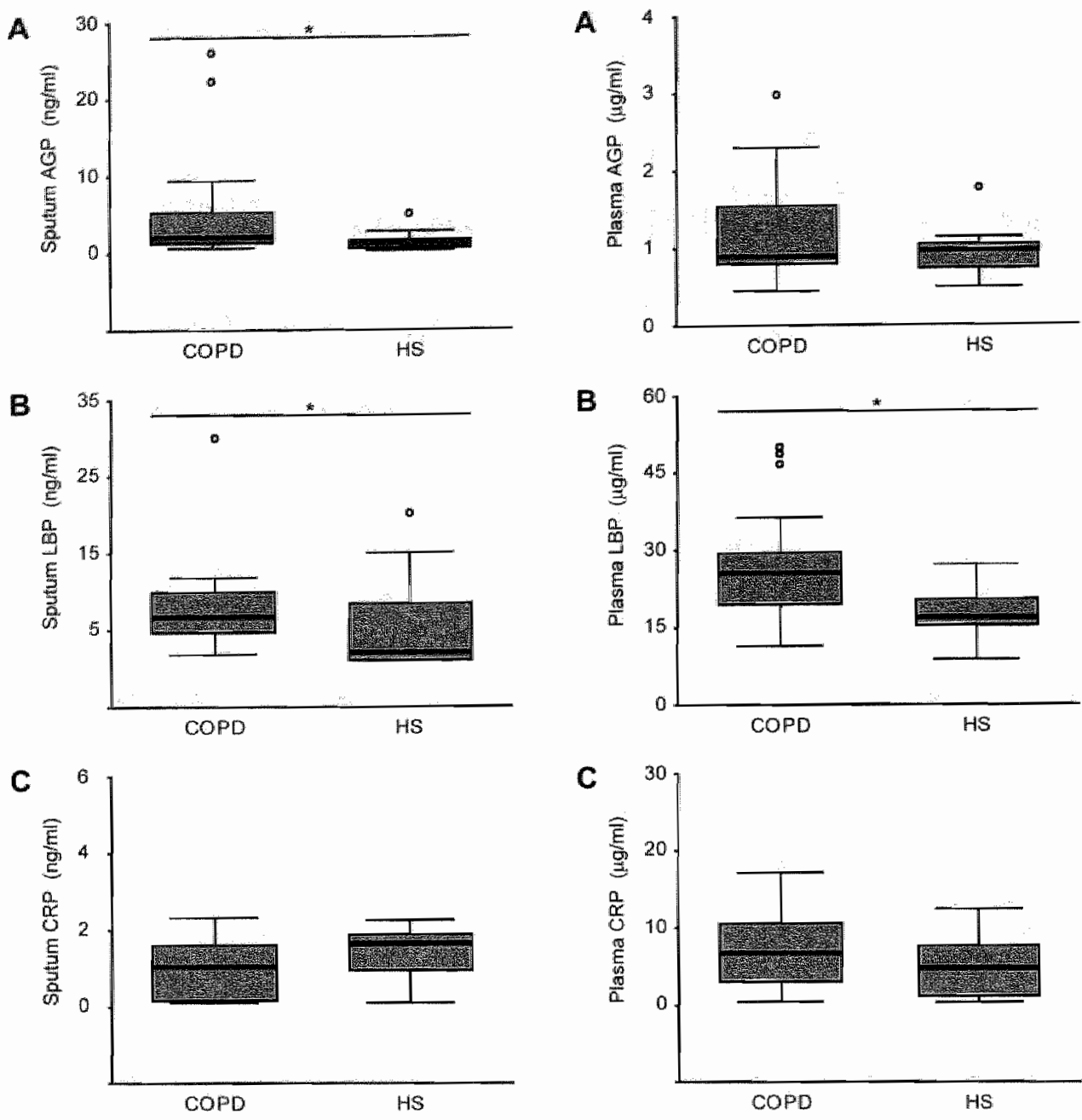

Figure 1, Levels of $(A), \alpha$, -glycoprotein $(A C P),(B)$ lipopolysaccharide binding protein (LBP), and (C) C-reactive protein (CRP) in induced sputum obtained from patients with chronic obstructive pulmonary disease (COPD) and heall thy smokers (HS). ${ }^{\circ}$ symbolizes outliers. * denotes p-value $<0.05$.

Figure 2. Levels of $(A) a_{1}$-glycoprotein (ACP), (B) lipopolysaccharide binding protein (LBP), and (C) C-reactive protein (CRP) in plasma of patients with chronic obstructive pulmonary disease (COPD) and healthy smokers (HS). ${ }^{\circ}$ symbolizes outliers. * denotes p-value $<0.05$.

IL-6 were not significantly different between the study groups, and did not display any correlation with the FEV

\section{Acute-phase reactants in sputum}

AGP, LBP, and CRP were detectable in the soluble phase of induced sputum samples of all subjects. As shown in Figure 1, sputum levels of both ACP and LBP were significantly increased in COPD patients when compared to healthy smokers. In 
contrast, CRP levels in sputum of COPD pattents tended to be lower in COPD versus controls, but this did not reach the level of statistical significance. Furthermore, sputum levels of AGP and LBP were positively correlated with each other, but not with sputum levels of CRP in both COPD patients and healthy smokers (data not shown).

Exploring the relationship between sputum levels of APRs and the degree of airflow limitation, we found an inverse correlation between the FEV values $(\%$ predicted) and sputum AGP levels in COPD patients, whereas not in healthy smokers (Table 3). In contrast, levels of LBP and CRP in sputum were not related to airflow limitation.

Tabile 3. Correlations between acute-phase reactants and airflow limitation in patients with COPD and healthy smokers*

\begin{tabular}{|c|c|c|c|c|}
\hline & \multicolumn{2}{|c|}{$\operatorname{COPD}(n=18)$} & \multicolumn{2}{|c|}{ Healthy Smokers $(n=16)$} \\
\hline & R Value & p Value & $R$ Value & $p$ Value \\
\hline \multicolumn{5}{|l|}{ Sputum } \\
\hline $\mathrm{FEV} / / \mathrm{AGP}$ & -0.674 & 0.003 & 0.243 & NS \\
\hline $\mathrm{FEV}_{1} / \mathbb{L B P}$ & -0.399 & NS & 0.234 & NS \\
\hline $\begin{array}{l}\mathrm{FEV}_{1} / \mathrm{CRP} \\
\text { Plasma }\end{array}$ & 0.227 & NS & 0.096 & NS \\
\hline $\mathrm{FEV}, / \mathrm{AGP}$ & 0.506 & 0.038 & 0.054 & $\mathbb{N S}$ \\
\hline $\mathrm{FEV}_{1} / \mathrm{LBP}$ & 0.550 & 0.022 & 0.333 & NS \\
\hline $\mathrm{FEV}_{1} / \mathrm{CRP}$ & 0.300 & NS & 0.037 & NS \\
\hline
\end{tabular}

* Pearson's rank correlation. COPD = chronic obstructive pulmonary disease; $\mathrm{AGP}=\alpha_{1}$-glycoprotein; CRP $=$ C-reactive protein; $L B P=$ lipopolysaccharide binding protein; FEV $F_{1}=$ forced expiratory volume in 1 second; NS = not significant.

\section{Acute-phase reactants in plasma}

Systemic acute-phase response was assessed by measuring plasma levels of AGP, LBP, and CRP. As shown in Figure 2, plasma LBP was markedly elevated in COPD patients when compared to healthy smokers. In addition, circulating levels of AGP and CRP tended to be increased in COPD versus healthy smokers, but this did not reach significance. Circulating levels of the three APRs investigated were positively correlated with each other in COPD patients, but not in healthy smokers.

Next, we investigated the relationship between the systemic acute-phase response and the degree of airflow limitation. In contrast to sputum, circulating levels of AGP and LBP showed a positive correlation with the FEV, values (\% predicted) in the COPD group, but not in healthy smokers (Table 3 ).

\section{Relationship between local and systemic compartment}

To investigate the possible relationship between local and systemic acute-phase response in COPD patients, we first determined to what extent the data are affected by microvascular leakage by measuring albumin levels in sputum and plasma. Sputum-to-plasma ratios of albumin (sputum albumin $[\mathrm{mg} / \mathrm{L}] / \mathrm{serum}$ albumin $[\mathrm{g} / \mathrm{L}]$ ) were not significantly different between the study groups (data not shown), indicating a similar degree of microvascular leakage in COPD patients and healthy smokers. Therefore, the values of the inflammatory mediators in sputum were not corrected for microvascular leakage. 
Investigating the relationship between local and systemic acute-phase response; we found no direct correlations between sputum and plasma concentrations of each APR analyzed neither in the combined study group ([AGP]: $r=0.007, p=0.963$; [LBP]: $r=0.251, p=0.113 ;[C R P]: r=0.070, p=0.666$ ) nor in the separate groups. These data suggest that APRs measured in sputum are locally produced rather than originating from the systemic compartment.

\section{DISCUSSION}

In this study, we present data on acute-phase reactants in sputum and plasma of patients with mild-to-moderate COPD and healthy smokers. AGP, CRP, and LBP were present in all induced sputum samples. Sputum levels of AGP and LBP were significantly increased in COPD patients when compared to healthy smokers, and inversely correlated with the $\mathrm{FEV}_{1}$ values in the combined study groups. On the other hand, sputum CRP was not different between the study groups. In plasma, LBP levels were markedly elevated in COPD patients versus healthy smokers, whereas AGP and CRP tended to be increased in COPD. In contrast to sputum, AGP and LBP in plasma were positively correlated to the degree of airflow limitation in COPD. Exploring the relationship between local and systemic acute-phase response, we found no direct correlations between sputum and plasma concentrations of each APR analyzed in any study group, despite the fact that APRs were strongly related with each other in the single compartments.

Previous studies investigating APRs in lung pathology demonstrated an increase in BALF levels of AGP and LBP in patients suffering from asthma or ARDS ${ }^{17-13}$. Herewith in line, we demonstrate elevated sputum levels of AGP and LBP in COPD patients versus healthy smokers, which showed an inverse correlation with the degree of airflow limitation. A similar inverse correlation was reported between $\mathrm{FEV}_{1}$ values and IL-8 and neutrophils, which are thought to be important in airway pathogenesis in $\mathrm{COPD}^{15,16}$. As the nature of APRs suggest that these proteins play a protective role in host defens $\mathrm{e}^{22}$, this observation may imply that host defense increases with low FEV values in COPD.

Investigating systemic inflammation in COPD patients, we previously demonstrated elevated plasma levels of CRP and $L B P^{1,2}$. In this study, we extended these results and showed that circulating levels of AGP and LBP were increased in mild-to-moderate COPD patients compared to healthy smokers. In contrast, no significant differences in circulating CRP levels were found. This discrepancy with previous studies may be due to differences in severity of disease, as in this study only patients with less severe COPD were included. When comparing levels of APRs in sputum and plasma, no direct correlations were found. In addition, sputum levels of $A G P$ and $L B P$ were inversily correlated with the degree of airflow limitation in the combined groups, whereas FEV, values and plasma levels of AGP and LBP were positively related. Thus, these results suggest that APRs measured in sputum may be due to local production rather than to microvascular leakage from the systemic compartment. 
There is increasing evidence of extrahepatic expression of APRS; especially at the interfaces between the outer environment and the interior of the host, like lung and intestine. Intestinal epithelial cells were demonstrated to express $\mathrm{ACP}^{23}, \mathrm{LBP}$ and serum amyloid $\mathrm{A}(\mathrm{SAA})^{24}$. Recent studies investigating resident lung cells showed that type II pneumocytes and alveolar macrophages are able to produce different APRs like $\angle B P, A G P, C R P$, and fibrinogen ${ }^{6 * 10}$. Future studies are clearly required to elucidate the origin of the APRs in sputum of patients with COPD.

The question raises which role the APRs in sputum may play in the pathogenesils of COPD. As suggested by its name, LBP (LPS-binding protein) strongly enhances sensitivity of cells for LPS by facilitating binding of LPS to CD14, resulting in intracellular signaling via the TLR-4/MD-2 pathway. Binding of LBP to Gram-negative bacteria has also been reported ${ }^{25}$, which was shown to enhance local inflammation as well as phagocytosis and clearance of bacteria in vitro ${ }^{26,27}$ and in wivo ${ }^{2.8}$. Of interest, LBP also accelerates clearance of LPS by type II pneumocytes ${ }^{29}$ as well as in the blood $^{30}$. Therefore, local production of LBP may play an important intermediary role in local host defense in COPD patients by assisting in the clearance of bacteria and enhancement of the local inflammatory response.

Similar to LBP, CRP is known to be involved in host defiense. CRP-mediated protection includes activation of the classical complement cascade and binding to different pathogens including bacteria, fungi, and yeast. The interaction of cell-or particle-attached CRP with phagocytic cells - macrophages and neutrophils - results to increased phagocytosis. In addition, interaction with CRP was demonstrated to activate monocytes/macrophages to secrete reactive oxygen species ${ }^{31}$ and proinflammatory cytokines ${ }^{32}$, whereas CRP appears to down-regulate activation of neutrophils ${ }^{33}$. Furthermore, CRP was found to block the attachment of S.pneumoniae and H.influenzae to human epithellal cells in vitro ${ }^{3 t}$. Although local CRP levels were not increased in COPD, presence of CRP in the airways may significantly protect against invading pathogens in regular smokers in general. In this respect, CRP in sputum of chronic bronchitis patients was shown to have anti-bactericidal activities in vitro ${ }^{1 *}$.

AGP is a highly negatively charged glycoprotein (reviewed by Fournier ${ }^{35}$ ) that was shown to have several immunomodulating effects, including inhibition of neutrophil infiltration and activation ${ }^{36,3 \%}$, modulation of LPS-induced cytokine secretion by monocytes/macrophages ${ }^{3 *}$, and induction of macrophage derived IL-1 receptor antagonist ( $L-1 R A)$ release ${ }^{39}$. Therefore, local expression of ACP may significantly protect against the deleterious effects of inflammation. Furthermore, AGP has the ability to bind and to carry numerous basic and neutral lipophilic drugs from endogenous and exogenous origin, like steroid hormones, which may be also be an important function in COPD patients who are prescribed inhalled sterolids. Regular use of inhaled steroids was, however, an exclusion criterion in the present study, and can therefore not account for the increased AGP levels found in sputum of COPD patients. The immunomodulatory as well as the binding activities of AGP have been shown to be partly dependent on carbohydrate composition ${ }^{35}$. In this respect, in asthma patients, fucosylation of AGP was shown to be altered and was suggested to give some additional information about the progression of the disease ${ }^{12}$. Although beyond the scope of the present study, it would be interesting to compare the 
fucosylation level of AGP in sputum and plasma in both study groups. We speculate that expression of APRs at the initial site of exposure to noxious particles may play a significant role in the host defence in this respect; local production may result in higher concentration in the microenvironment and may shorten the time path when compared to extravasation of circulating APRs.

\section{ACKNOWLEDGEMENTS}

The authors thank Dr. A.M.W.J. Schols for expert assistance with the statistical evaluation of the data. This study was supported by a grant from Glaxo Wellcome, The Netherlands.

\section{REFERENCES}

1. Schols AM, Butrman WA, Staal van den Brekel A., Dentener MA, and Wouters EF. Evidence for a relation between metabolic derangements and increased levels of inflammatory mediators in a subgroup of patients with chronic obstructive pulmonary disease. Thorax $1996,51: 819-824$.

2. Dentener MA, Creutzberg EC, Schols AM, Mantovani A, van't Veer C, Buurman WA, and Wouters EF. Systemic anti-inflammatory mediators in COPD: increase in solluble interleukin 1 receptor Il during treatment of exacerbations. Thorax 2001:56:721-726.

3. Dahl M, Tybjaerg-Hansen A, Vestbo J, Lange $P$, and Nordestgaard BG. Elevalted plasma fibrinogen associated with reduced pulmonary function and increased risk of chronic obstructive pulmonary cisease. Am / Respir Crit Care Med 2001;164:1008-10\#1.

4. Takabatake $N$, Nakamura H, Abe $S$, Inoue S, Hino T, Saito H, Yuki H, Kato S, and Tomoike H. The relationship between chronic hypoxemia and actiwation of the tumor necrosis factor-alpha system in patients with chronic obstructive pulmonary disease. Am / Respir Crit Care Med 2000"161:1179. 1184.

5. Eid AA, Ionescu AA, Nixon LS, Lewis-Jenkins V, Matthews SB, Griffiths $\mathrm{TL}_{\text {, }}$ and Shale DJ. Inflammatory response and body composition in chronic obstructive pulmonary disease. Am/Respir Crit Care Med $2001 ; 164: 1414-1418$.

6. Dentener MA, Vreugdenhil $\mathrm{AC}$, Hoet $\mathrm{PH}$, Vernooy $\mathrm{JH}$, Nieman $\mathrm{FH}_{x}$ Heumann $\mathrm{D}$, Janssen $\mathrm{YM}$. Butuman WA, and Wouters EF. Production of the acute-phase protein lipopolysaccharide-binding protein by respiratory type II epithelial cells: implications for local defense to bacterial enclotoxins. Am J Raspir Cell Mol Biol $2000 ; 23: 146 ; 153$.

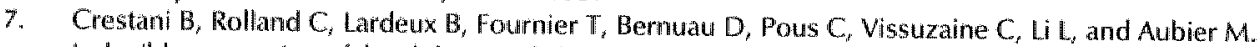
Inducible expression of the alphal-acid glycoprotein by rat and human type ll alveolar epithelial cells. I Immunol 1998; $160: 4596-4605$.

8. Cuadiz G, Spom LA, Coss RA, Lawrence SO, Marder VI, and Simpson Haidaris PI. Polarized secretion of fibringgen by luing epithelial cells. Am / Respir Cell Mol Biol 1997;17:60 69.

9. Dong Q, and Wright JR. Expression of C-reactive protein by alweolar macrophages. / Immunol $1996 ; 156: 4845-4820$.

10. Fournier T, Bouach N, Delalosse C, Crestani B, and Aubier M. Inducible expression and regulation of the alpha 1 acid glycoprotein gene by alveolar macrophages: prostaglandin $\mathbb{E} 2$ and cyclic $A M A$ act as new positive stimuli. I Immunol 1999;163:2883-2890.

11. Dubin W, Martin TR, Swoveland P, Leturcq DI, Moriarty AM, Tobias PS, B Heecker ER, Goldblum SE, and Hasday ID. Asthma and endotoxin: lipopolysaccharide-binding protein and soluble CD14 in bronchoalveolar compartment. Am \& Physiol 1996;270:L736-744

12. Van Den Heuvel MM, Poland DC, De Graff CS, Hoefsmit EC, Postmus PE, Beelen RH, and Van Dijk W. The degree of branching of the glycans of alpha(1)-acid glycoprotein in asthma. A correlation with lung function and inflammatory parameters. Am / Respir Crit Care Med 2000;161:1972 "1978. 
13. Martin TR, Rubenfeld GD, Ruzinski IT, Goodman RB, Steinberg KP, Leturcq DJ, Mortarty AM, Raghu $\mathrm{G}_{3}$ Baughman RP, and Hudson LD. Relationship between soluble CD 14, lipopolysaccharide binding protein, and the alveolar inflammatory response in patients with acute respiratory distress syndrome. Am J Respir Crit Care Med 1997; 155:937-944.

14. Gould $J M$, and Weiser $J \mathbb{N}$. Expression of $C$-reactive protein in the human respiratory tract. Infect Immun 2001; 69:1747-1754.

15. Keatings VM, Collins. PD, Scot DM, and Barnes PJ. Differences in interleukin-13 and tumor necrosis factor-alpha in induced sputum from patients with chronic obstructive pulmonary disease or asthma. Am J Respir Crit Care Med 1996;153:530-534.

16. Vennooy JHI, Kücükaycan $M$, Jacobs JA, Chavannes NH, Buturnan WA, M.A. D, and E.F.M. W. Local and Systemic Inflammation in Patients with Chronic Obstructive Pulmonary Disease: Soluble Tumor Necrosis Factor Receptors are Increased in Sputum. Am / Respir Crit Care Med 2002;166:1218-1224.

17. ATS. Standards for the diagnosis and care of patients with chronic obstructive pulmonary disease. Am I Respir Crit Care Med 1995;152:577-121.

18. Froon $\mathrm{AH}_{s}$, Dentener $M A$, Greve JW, Ramsay $\mathrm{G}_{n}$ and Buurman WA, Lipopolysaccharide toxicityregulating proteins in bacteremia. J Infect Dis 1995;171:1250-1257.

19. van Dielen FM, van't Veer C, Schols AM, Soeters PB, Buurman WA, and Greve JW. Increatsed leptim concentrations correlate with increased concentrations of inflammatory markers in morbidly obese individuals. Int / Obes Relat Metab Disord 2001;25:1759-1766.

20. Bouma MG, Stad $R K$, van den Wildenberg $\mathbb{F} A$, and Butrman WA. Differential regulatory effects of adenosine on cytokine release by activated human monocytes. I Immunol 1994;153:4159-4168.

21. Dentener $M A$, Bazil $V$, Von Asmuth EJ, Ceska $M$, and Buuman WA. Involvement of CD14 in lipopolysaccharide-induced tumor necrosis factor-alpha, IL-6 and IL-8 release by human monocytes and alveolar macrophages. I mmonol 1993; $150: 2885-2891$.

22. Steel DM, and Whitehead AS. The major acute phase reactants: C-reactive protein, serum amyloid $\mathrm{P}$ component and serum amyloid A protein. Immunol Today 1994;15:81-88.

23. Boudreau F, Yu SI, and Asselin C. CCAAT/enhancer binding proteins beta and delta regulate alpha T. acid glycoprotein gene expression in rat intestinal epithelial cells. DNA Cell Biol 1998;17:669-677.

24. Vreugdenhil $A C_{y}$ Dentener MA, Snoek $A M$, Greve $\mathrm{W}$, and Bururman WA. Lipopolysaccharide binding, protein and serum amyloid $A$ secretion by human intestinal epithelial cells during the acute phase response. I Inmunol 1999;163:2792-2798.

25. Lengacher 5 , Jongeneel $C V$, Le Roy $D$, Lee JD, Kravchenko $V$, Ulevitch R, Glauser MP, and Heumann D. Reactivity of murine and human recombinant LPS-binding protein (LBP) within LPS and gram negative bacteria. / Inflarmm 1995;47:165-172.

26. Crunwald $U$, Fan $X$, Jack RS, Workallemahu $G_{i}$ Kallies $A$, Stelter $F$, and Schutt $C$. Monocytes can phagocytose Gram-negative bacteria by a CD14-clependent mechanism. J Immunol 1996;157:4119. 4125 .

27. Lazou Ahren I, Biartell $A$, Egesten $A$, and Riesbeck K. Lipopolysaccharide-binding protein increases toll-like receptor 4-dependent activation by nontypeable Haemophilus influenzae. I Infect Dis 2001; 184:926-930.

28. Fan MH, Kllein RD, Steinstraesser L. Merry AC, Nemzek JA, Remick DG, Wang SC, and Su GL. An essential role for lipopolysaccharide-binding protein in pulmonary innate immune responses. Shock $2002 ; 18: 248.254$.

29. Hamann L, Stamme C, Ulmer $\mathrm{A}$, and Schumann RR. Inhibition of LPS-induced activation of alveolar macrophages by high concentrations of LPS-binding protein. Biochem Biophys Res Commun $2002 ; 295: 553-560$.

30. Vreugdenhil $A C$, Snoek $A M$, van "t Veer $C$. Greve JW, and Buurman WA. LPS-binding protein circulates in association with apoB-containing lipoproteins and enhances endotoxin-LDL/VLDL interaction. /Clin Invest 2001;107:225-234.

31. Zeller $M M$, Landay $\mathrm{AL}_{\text {, Lint }} \mathrm{TF}_{\text {, and }}$ Gew/urz $\mathrm{H}$. Enhancement of human peripheral blood monocyte respiratory burst activity by aggregated C-reactive protein. / Leukoc Biol 1986;40:769-783.

32. Galwe-de Rochemonteix $B$, Wiktorowicz $K$, Kushner I, and Dayer JM. C-reactive protein increases production of IL-1 alpha, IL-1 beta, and TNF-alpha, and expression of mRNA by human alveolar macrophages. / Leukoc Biol 1993;53:439-445.

33. Volanakis IE. Human C-reactive protein: expression, structure, and function. Mof Imonumol 2001; 38:1189-197. 
34. Gould $M$, and Weiser $\mathrm{IN}$, The inhbitory effect of $C$-reactive protem on bacherial phosphorylcholine platelet-activating factor receptor-mediated adherence is blacked by surfactant I infect Dis $2002 ; 186: 361-371$

35. Foumier T, Medjoubi NN, and Porquet D. Alphia-1-acid glycoprotein. Biochim Biophys Acta $2000 ; 1482: 157-171$

36. Laine E, Couderc R, Roch-Arveiller M, Vasson MP, Groud JP, and Raichvarg D. Modulation of human polymorphonuclear neutrophi functions by alpha 1-acid glycoprotein. Inflammation 1990;14:1-9.

37. Muchitsch EM, Varadi $K$, and Pichler $L$ Effects of alpha 1 acid glycoprotein on acute pancreatitis and acute lung injury in rats. Arzieimittelforschung 2000;50:987-994.

38. Boutten $A$, Dehoux $M$, Deschenes $M$, Rouzeau 10 , Bories $P N$, and Durand $G$. Alpha 1-acid glycoprotein potentates lipopolysacharide-induced secretion of interleukin 1 beta, interleukin- 6 and turnor necrosis factor-alpha by human monocytes and alveolar and peritoneal macrophages. Eur \& Immunol $1992 ; 22: 2687-2695$.

39. Bories PN, Feger I, Benbernou N, Rouzeau JD, Agneray l, and Durand G. Prevalence of tri- and tetraantennary glycans of human alpha 1 -acid glycoprotein in release of macrophage inhibitor of interleukin-1 activity. Inflammation 1990;14:315-323. 


\section{CHAPTER 5}

\section{Leptin as local inflammatory marker in COPD}

Roelinka Broekhuizen, Juanita H.J. Vernooy, Annemie M.W.J. Schols, Mieke A. Dentener, Emiel F.M. Wouters

Department of Respiratory Medicine, University Hospital Maastricht, Maastricht, The Netherlands

Submitted

\section{ABSTRACT}

Introduction: COPD is characterized by chronic inflammation of the lung. Leptin is a pleiotropic cytokine thought to play a role in host response to inflammation. As recent studies have shown that leptin receptors are present in the lung, this study aimed to determine if leptin is detectable in induced sputum of COPD patients and if there is a relationship between leptin and inflammatory markers in sputum. Methods: Sputum was induced in 14 male patients with moderate COPD (FEV $58 \%$ (11) pred.). Leptin, total tumor necrosis factor (TNF)- $\alpha$, soluble (s) TNFreceptors (TNF-R) 55 and 75, and C-reactive protein (CRP) were analyzed in induced sputum supernatant by ELISA. Leptin was also determined in EDTA plasma. Resuits: Leptin was detectable in induced sputum of 10 COPD patients. A significant relationship was found between sputum leptin and CRP ( $r=0.94$, $p<0.000)$ and total TNF- $\alpha(r=0.69, p=0.006)$, whereas leptin was inversely related to sTNF-R55 $(r=-0.54, p=0.047)$ and STNF-R75 $(r=-0.60, p=0.038)$. Plasma leptin and sputum leptin were inversely correlated $(r=-0.64, p=0.013)$. Conclusion: The present study demonstrated that leptin is detectable in induced sputum of patients with moderate COPD. The observed correlations between leptin and inflammatory markers in sputum may indicate that leptin is involved in the local inflammatory response in COPD. 


\section{INTRODUCTION}

Leptin, initially discovered as a regulator of food intake and energy expenditure, is emerging as a pleiotropic cytokine. It is involved in a variety of physiological and pathological functions, including the regulation of hematopoiesis, angiogenesis, wound healing, and the immune response and inflammatory response (reviewed by Fantuzzi ${ }^{1}$ ). The receptor for leptin (leptin-R) has been demonstrated to be present throughout the body, including the airways ${ }^{2}$, which may suggest a specific function of leptin in the airways.

Although the pathogenesis of chronic obstructive pulmonary disease (COPD) is not clear, patients with COPD have been shown to exhibit a chronic inflammation in the airways. Elevated numbers of alveolar macrophages and $\mathrm{CD} 8+\mathrm{T}$ cells have been found in the peripheral airways and lung parenchyma. In addition, an increased level of neutrophils has been demonstrated in sputum and bronchoalveolar lavage (BAL) fluid of COPD patients. Furthermore, an increase in interleukin-8 (IL-8) and tumor necrosis factor- $\alpha$ (TNF- $\alpha$ ), which are assumed to act as chemo-attractants for neutrophils, has been reported in sputum of COPD patients (reviewed by Barnes ${ }^{3}$ ).

In order to unravel the potential role of leptin in this focus of chronic inflammation, we investigated if leptin is detectable in induced sputum of patients with COPD. If so, the second objective was to relate leptin levels to inflammatory markers in induced sputum.

\section{MATERIAL \& METHODS}

The study population consisted of male patients with clinically stable moderate COPD, defined according to the criteria of the American Thoracic Society (ATS). Exclusion criteria were regular use of inhaled steroids, a history of respiratory disease other than COPD and a recent exacerbation (4 weeks prior to inclusion). Forced expiratory volume in one second $\left(\mathrm{FEV}_{1}\right)$ was calculated from the flow volume curve using a spirometer (Masterlab, Jaeger, Würzburg, Germany) applied before and $15 \mathrm{~min}$. after inhalation of a $\beta$-agonist via a metered-dose inhaler. FEV, was expressed as the percentage of reference values. Fat-free mass (FFM; $\mathrm{kg}$ ) was estimated using single frequency $(50 \mathrm{kHz})$ bio-electric impedance analysis (Xitron Technologies, San Diego, CA, USA). The ethical review board of the University Hospital Maastricht approved the study. All subjects gave written informed consent.

Sputum was induced through inhalation of $3 \%$ hypertonic saline and processed with $0.1 \%$ dithiothreitol (DTT; Sputolysin; Calbiochem, La Joila, CA) according to the procedure described by Keatings and coworkers. ${ }^{4}$. Blood was collected in evacuated blood collecting tubes containing EDTA (Sherwood Medical, St. Louis, $\mathrm{MO}$ ) in the morning before sputum induction (8.00-12.00 AM). Sputum and plasma samples were stored at $-80^{\circ} \mathrm{C}$ until analysis.

Leptin was measured in induced sputum supernatant and plasma by sandwich 
enzyme-linked immunosorbent assay (ELISA). C-reactive protein (CRP), total TNF$\alpha$ (i.e. free TNF- $\alpha$ and TNF- $\alpha$ bound to soluble TNF-receptors), sTNF-R55 and STNF-R75 were determined in induced sputum supernatant by ELISA as described $^{5-7}$. Lower detection limits: $120 \mathrm{pg} / \mathrm{ml}$ for leptin, $100 \mathrm{pg} / \mathrm{ml}$ for CRP, 20 $\mathrm{pg} / \mathrm{ml}$ for total TNF- $\alpha, 60 \mathrm{pg} / \mathrm{ml}$ for sTNF-R55, and $30 \mathrm{pg} / \mathrm{ml}$ for sTNF-R75. Presence of DTT resulted in less than $10 \%$ inhibition of the detection of inflammatory mediators (data not shown).

Results are presented as mean \pm standard deviation (SD) for normally distributed variables. Plasma leptin levels were adjusted for fat mass when indicated. Correlations between parameters were calculated with Pearson's rank correlation analysis using SPSS (Statistical Package for the Social Sciences, version 10.1 for Windows, SPSS Inc., Chicago, IL, U.S.A.). Significance was assessed at a p-value of 0.05 .

\section{RESULTS}

Fourteen weight-stable male patients with moderate COPD (FEV ${ }_{1}: 58$ (11) \% predicted) were included in this study. Mean smoking history of the study population was 52.8 (28.3) pack years with 4 patients having quit smoking for at least 1 year and 10 patients still smoking. Mean age was 59.9 (8.3) years and body mass index was $26.2(3.6) \mathrm{kg} / \mathrm{m}^{2}$. All patients tolerated the procedure of sputum induction well and produced an adequate specimen of sputum for analysis.

Leptin level in sputum was detectable in 10 of 14 patients. The mean value of leptin in sputum was $275(135) \mathrm{pg} / \mathrm{ml}$. In plasma, leptin was detectable in all samples, with a mean level of 6915 (3681) $\mathrm{pg} / \mathrm{ml}$. After adjustment for fat mass, which correlated positively with leptin $(r=0.719, p=0.008)$, leptin level was 290 (110) $\mathrm{pg} / \mathrm{ml} / \mathrm{kg}$. Leptin in plasma and in induced sputum were inversely correlated $(r=-0.64, p=0.013)$, a correlation which was no longer significant after plasma leptin had been adjusted for fat mass. In induced sputum,

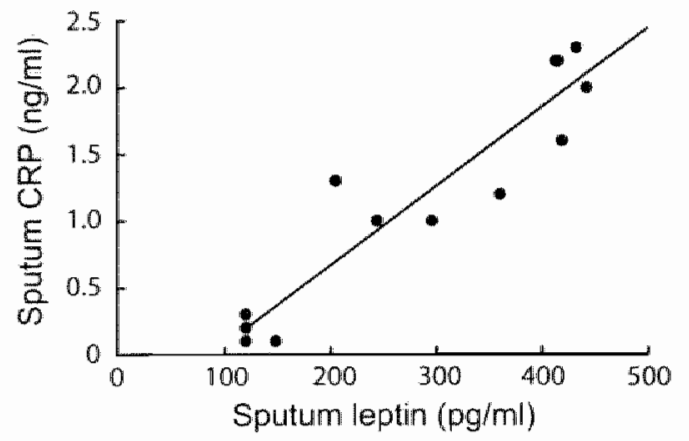
leptin level was strongly correlated with the acute phase protein CRP $(r=0.94, p<0.000)$ (Figure 1) and with sputum TNF- $\alpha$ levels $\quad(r=0.69$, $p=0.006$ ). In contrast, it was imversely related to STNF-R55 $(r=-0.54, p=0.047)$ and sTNF. $R 75(r=-0.60, p=0.038)$.

Figure 1. Correlation between leptin and CRP levels in induced sputum $(r=0.94, p<0.000)$ 


\section{DISCUSSION}

Chronic airway inflammation is considered to be a hallmark of COPD. The present study shows that leptin is detectable in induced sputum of COPD patients. Leptin was positively correlated with CRP and TNF- $\alpha$, and inversely related with STNFreceptors in sputum. Previous studies showed profound neutrophilia and increased levels of IL-8, TNF- $\alpha$ and soluble TNF-receptors in sputum of COPD patients versus controls, which correlated highly with each other and with the degree of aiffow limitation. The finding that sputum leptin was positively correlated with CRP and TNF- $\alpha$ in these patients suggests that leptin is involved in the local inflammatory response in COPD. This hypothesis is supported by the fact that the structure of leptin and its receptor (leptin- $R$ ) resemble cytokine structures, which suggests that leptin is a member of the cytokine family.

The structure of leptin- $R$ is homologous to gp-130, the signaling transducing subunit of IL-6 family cytokines, which are important inducers of acute-phase proteins like CRP. CRP is involved in first line of innate host defense, which includes activation of the classical complement cascade and mediating phagocytosis. Recent studies demonstrated extrahepatic expression of CRP in human respiratory epithelial cells and in stimulated human alveolar macrophages,9. In addition, CRP detected in sputum of chronic bronchitis patients was shown to have anti-bactericidal activities in vitro ${ }^{8}$. We speculate that induction of CRP at the initial site of injury may enhance the early phase of specific local responses to infection and injury. The observed correlation between sputum leptin and CRP suggest that leptin may play a functional role in the acutephase response.

TNF- $\alpha$ is a pro-inflammatory cytokine with pleiotropic effects that acts via two related membrane-bound receptors. In the lung, TNF- $\alpha$ is mainly produced by activated macrophages in response to inflammatory stimuli and functions as a chemoattractant for inflammatory cells like neutrophils. Soluble TNF-receptors in sputum are suggested to be derived from activated neutrophils ${ }^{7}$, which shed TNFreceptors from the cell surface in response to inflammatory mediators. Our observation that leptin is positively correlated with TNF- $\alpha$ and inversely with sTNF-receptors, may seem contradictory as sTNF-receptors are generally considered to be markers of a pro-inflammatory state. However, the functional role of sTNF-receptors in COPD is still uncertain. Soluble TNF-receptors are known to compete for TNF- $\alpha$ with membrane-bound TNF-receptors, and may hereby play a role in regulating steady state levels of TNF- $\alpha$ in the lungs. In this respect, the correlations of leptin with TNF- $\alpha$ and sTNF-receptors suggest that shedding of TNF-receptors may function in scavenging of TNF- $\alpha$, and STNFreceptors may therefore have anti-inflammatory effects in sputum.

The inverse correlation between sputum leptin and plasma leptin found in the present study makes it unlikely that the presence of leptin in sputum is attributable to microvascular leakage from the plasma leptin pool. In this respect, leptin could be synthesized in the lung itself. Fetal rat lung fibroblasts, which are adipocyte-like cells, are reported to secrete leptin ${ }^{10}$. In addition, preliminary 
observations by Bruno and co-workers suggested an increased expression of leptin in the submucosa of bronchial biopsies of patients with COPD compared to controls ${ }^{11}$. Future research is needed to elucidate the origin of leptin in the lung. The presence of leptin and the high concentrations of leptin receptor found in the lung ${ }^{2}$ strongly suggest a specific local function of leptin. To date, only few studies have addressed this topic. Leptin was demonstrated to stimulate cell proliferation in tracheal epithelial cells in vitro, suggesting that leptin may function as a growth factor helping to maintain the epithelial barrier. It could also play a role in the local immune response, as leptin receptors are found on neutrophils ${ }^{12}$ and $T$ cells ${ }^{11}$ and as is suggested by the results found in the present study.

Activation of neutrophil-bound leptin receptors showed an increase in production of oxidative species ${ }^{12}$. The regulation of oxidative capacity may be a way of leptin to modulate PMN function. In addition, leptin-deficient mice are found to have impaired host defense against bacterial pneumonia with increased mortality. This was associated with reduced bacterial clearance and with defective alveolar macrophage phagocytosis in vitro. The addition of leptin has been found to restore this defect ${ }^{13}$. In this case, leptin was found to protect against the damaging effects of bacterial infection and seems to play a role in the early innate immune response.

Research in other local compartments, like the intestine and liver, which both originate from the same embryonic entodermic stem cells as the lungs, showed that leptin deficiency protects against chemically induced models of inflammatory disease like colitis and hepatotoxicity. This resistance found in ob/ob mice coincided with decreased levels of the pro-inflammatory cytokine TNF- $\alpha$ and decreased level of CD8 + T cells. In addition, leptin administration completely restored susceptibility to levels comparable to those of the wild type mice ${ }^{1+1,15}$. These findings suggest a crucial role for leptin in the etiology of T cell-mediated inflammatory disease. This may be important in COPD as T cell activation was demonstrated in bronchial mucosa of subjects with chronic bronchitis. In addition, preliminary observations by Bruno and colleagues demonstrated leptin-R expression on $T$ cells in bronchial biopsies of COPD patients ${ }^{11}$. Leptin may alfect lymphocytes by increasing the expression of activation markers, regulating production of cytokines by $T$ cells, and polarizing $T$ helper (Th) cells toward a Th' phenotype ${ }^{12}$.

Taken together, current data suggest that leptin may be involved in the acquired immune system in COPD. Future studies are clearly necessary to elucidate the role of leptin in airways of COPD patients.

\section{ACKNOWLEDGEMENTS}

The authors thank Prof. W.A. Buurman (General Surgery, Maastricht University, Maastricht, The Netherlands) for kindly providing the reagents for the ELISAS used in this study. The present work was supported by a research grant from Glaxo Wellcome, The Netherlands. 


\section{REFERENCES}

1. Fantuzzi $G$, and Faggioni $R$. Leptin in the regulation of immunity, inflammation, and hematopoiesis. J Leukoc Biol 2000,68:437-446.

2. Tsuchiya $T$, Shimizu $H$, Horie $T$, and Mori $M$. Expression of leptin receptor in lung: leptin as a growth factor. Eur / Pharmacol 1999;365:273-279.

3. Barnes PJ. Chronic obstructive pulmonary disease $N$ Engl J Med 2000;343:269-280.

4. Keatings VM, Collins PD, Scott DM, and Barnes PJ. Differences in interteukin-8 and tumor necrosis factor-alpha in induced sputum from patients with chronic obstructive pulmonary disease or asthma. Ain / Respir Crit Care Med 1996:153:530-534.

5. Van Dielen FM, vant Veer $C$, Schols $A M$, Soeters $P B$, Buurman WA, and Greve 1 W. Increased leptin concentrations correlate with increased concentrations of inflammatory markers in morbidly obese individuals. Int J Obes Relat Metab Disord 2001;25:1759-1766.

6. Leeuwenberg JF, Jeunhomme TM, and Buurman WA. Slow release of soluble TNF receptors by monocytes in vitro. J Immunol 1994; $152: 4036-4043$.

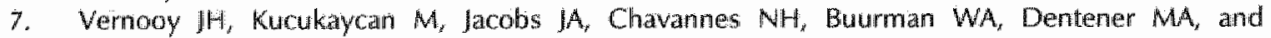
Wouters EF. Locall and systemic inflammation in patients with chronic abstructive pulmonary disease: soluble tumor necrosis factor receptors are increased in sputum. Am / Respir Crit Care Med 2002;166:1218-1224.

8. Gould JM, and Weiser $\mathrm{N}$. Expression of C-reactive protein in the human respiratory tract. Infect Immun 2001,69:1747-1754.

9. Dong Q, and Wright $\mathbb{R}$. Expression of C-reactive protein by alveolar macrophages. / /mmunol $1996 ; 156: 4815-4820$.

10. Torday $J S$, Sun $H$, Wang L, Torres $E$, Sunday ME, and Rubin LP. Leptin mediates the parathyroid hormone-related protein paracrine stimulation of fetal lung maturation. Am / Physiol Lung Cell Mol Physiol 2002;282:L405-410.

11. Bruno $A$, Chiappara $G$, Chanez $P$, Merendino $A M$, Giammanco $S$, Bellia $V$, Bonsignore $G$, and Wignola AM. Expression of leptin and leptin receptor in broncial biopsies of COPD and asthmatic subjects. Am J Respir Cirt Care Med 2002;165:A559.

12. Faggioni $\mathbb{R}_{f}$ Feingold $K R$, and Girunfeld $C$. Leptin regulation of the immune response and the immunodeficiency of malnutrition. Faseb / 2001;15:2565-2571.

13. Mancuso P, Gottschalk A, Phare SM, Peters-Golden M, Lukacs NW, and Huffnagle CB. Leptindeficient mice exhibit impaired host defense in Gram-negative pneumonia. I Immunol $2002 ; 168: 4018-4024$.

14. Siegmund $B$, Lehr $H A$, and Fantuzzi $G$. Leptin: a pivotal mediator of intestinal inflammation in mice. Gastroenterology 2002;122:2011-2025.

15. Faggioni $R$, Jones-Carson J, Reed $D A$, Dinarello $C A$, Feingold $K R$, Grunfeld $C$, and Fantuzzi $G$, Leptindeficient (ob/ob) mice are protected from I cell-mediated hepatotoxicity: rolle of tumor necrosis factor alpha and IL-18. Proc Natl Acad Sci U S A 2000;97:2367-2372. 


\title{
CHAPTER 6
}

\section{Increased activity of matrix metalloproteinase (MMP)-8 and MMP-9 in induced sputum from patients with COPD}

\author{
Juanita H.J. Verinooy', Jan H.N. Lindeman ${ }^{2,3}$, Jan A. Jacobs", Roeland \\ Hanemaaijer", and Emiel F.M. Wouters
}

Departments of "Respiratory Medicine and "Medical Microbiology, University Hospital Maastricht, Maastricht, The Netherlands; ${ }^{2}$ Department of Vascular and Connective Tissue Research, TNO Prevention and Health, Leiden, The Netherlands; ${ }^{3}$ Department of Vascular Surgery, Leiden

University Medical Center, Leiden, The Netherlands

\section{Submitted}

\section{ABSTRACT}

Matrix metalloproteinases (MMPs) are suggested to play a critical role in the pathogenesis of chronic obstructive pulmonary disease (COPD), but quantitative data on MMP activity in airways are lacking. This study aimed to quantify collagenase (MMP-1 and MMP-8) and gelatinase (MMP-9) activity in induced sputum of 17 well-characterized mild-to-moderate COPD patients (FEV $56 \%$ pred) and 17 healthy smokers ( $\mathrm{FEV}, 99 \%$ pred). Using specific immuno-capture assays that allow determination of both active and potentially activatable (total) proteinases, we found a significant increase of both active and total activity of MMP-8 and MMP-9 in COPD patients versus healthy smokers, whereas MMP-1 activity was not increased. MMP-8 and MMP-9 (active and total) were strongly correlated, and were related to the absolute number of neutrophils in both study groups. In addition, an inverse correlation between MMP-8 and MMP-9 activity in sputum and airflow obstruction $\left(\mathbb{F E V}_{3}\right)$ was found in the combined study groups. Cellular distribution of MMP-8 and MMP-9 was assessed by immunohistochemistry on sputum cytospins. Strong positive staining for MMP-9 was found in both alveolar macrophages and neutrophils, whereas specific MMP-8 staining was exclusively observed in neutrophils. The presence of increased MMP8 and MMP-9 activity in the airways of mild-to-moderate COPD patients supports the concept of an impaired proteinase-anti-proteinase balance in COPD. 


\section{INTRODUCTION}

Chronic obstructive pulmonary disease (COPD) is a complex, heterogeneous respiratory disease, clinically defined by development of a progressive, largely irreversible airflow limitation and emphysematous degeneration. The pathophysiologic basis for COPD has not been elucidated, but it is generally conceived that chronic exposure to noxious particles such as those present in cigarette smoke induces a sustained and extensive inflammatory response throughout the airways, lung parenchyma, and pulmonary vasculature is supported by recent studies demonstrating that the severity of COPD and the number of various inflammatory cells in the lung are strongly correlated ${ }^{2-\theta}$.

The chronic inflammatory response in COPD is associated with a proteinaseanti-proteinase imbalance that is held responsible for the destruction of lung parenchyma, but that also interferes with normal tissue function and repair through proteolysis of receptors and/or ligands $\mathrm{s}^{9,10}$. As yet, the actual proteolytic culprits responsible for the progression of COPD have not been identified. Traditionally, attention has been primarily focused on neutrophil elastase, but this hypothesis is hardly corroborated by clinical and experimental data.

Evidence from animal studies as well as preliminary studies in man suggests that members of the matrix metalloproteinase (MMP) family are critically involved in the pathogenesis of COPD. MMP expression is increased in emphysematous lung tissue ${ }^{1.13}$ and elevated MMP levels are found in bronchoalveolar fluid of emphysematous patients ${ }^{13,4}$. Furthermore, inhibition of MMP activity attenuates the emphysematous changes in an experimental model of COPD ${ }^{15}$.

MMPs comprise a large family of structurally related zinc metalloendopeptidases with different substrate specificities, collectively able to degrade most, if not all, protein constituents of the extracellular matrix ${ }^{16,17}$. The net MMPactivity represents a highly regulated process involving regulation of gene expression, activation and inhibition by specific inhibitors. The critical question, how MMP mRNA and protein expression in COPD translates into net proteinase activity, is not addressed by conventional methods assessing proteinase mRNA or protein expression. We have now used new specific assays that are able to distinguish between active and latent MMP forms, and analysed MMP collagenase (MMP-1 and MMP-8) and gelatinase (MMP-9) activity in induced sputum of wellcharacterized COPD patients with mild-to-moderate disease ${ }^{8}$ and healthy smokers matched for age and smoking history. In addition, cellular distribution of MMP-8 and MMP-9 was assessed by immunohistochemistry on cytospins of sputum cells.

\section{MATERIAL \& METHODS}

\section{Subjects}

Seventeen patients with smoking-related, clinically stable COPD, which met American Thoracic Society (ATS) criteria for the diagnosis of COPD ${ }^{13}$, were included. Criteria for inclusion were stable airflow limitation with a forced 
expiratory volume in 1 second $\left(\mathrm{FEV}_{1}\right)<70 \%$ predicted with reversibility $<11 \%$ predicted $\mathrm{FEV}_{1}$ or $<200 \mathrm{ml}$ following inhaled B2-agonist administration (Spirometer, Masterlab, Jaeger, Würzburg, Germany), and a previous history of at least 20 pack-years of smoking. Exclusion criteria were a history of respiratory disease other than COPD as well as increased respiratory complaints or respiratory tract infection during 4 weeks preceding the study. A control group of so-called healthy smokers was recruited consisting of 17 subjects with a normal FEV , no medical history of lung disease, and a smoking history of at least 15 packyears. The study was approved by the medical ethics committee of the University Hospital of Maastricht. Written informed consent was obtained from all subjects.

Table 1. Characteristics of the study groups investigated"

\begin{tabular}{lccc}
\hline & $\begin{array}{c}\text { COPD } \\
(n=18)\end{array}$ & $\begin{array}{c}\text { Healthy Smokers } \\
(n=17)\end{array}$ & p Value \\
\hline Mean age, yr & $60.9 \pm 8.1$ & $54.6 \pm 6.9$ & 0.017 \\
Cender, M/F & $16 / 2$ & $6 / 11$ & 0.001 \\
Mean FEV $1, \%$ predicted & $55.5 \pm 14.3$ & $98.7 \pm 16.2$ & $<0.001$ \\
Pack-years & $47.9 \pm 28.0$ & $32.3 \pm 13.2$ & 0.045 \\
Current smoker & 12 & 10 & $\mathrm{NS}^{4}$ \\
Ex-smoker & 6 & 7 & $\mathrm{NS}^{4}$ \\
\hline
\end{tabular}

* Values are means $\pm \mathrm{SD} ;{ }^{1}$ Student $\mathrm{T}$-test; ${ }^{1}$ Chi-square test. $\mathrm{COPD}=$ chronic obstructive pulmonary disease; $M=$ male; $F=$ female; $F E V_{1}=$ forced expiratory volume in 1 second; pack-year $=$ smoking 1 pack per day for $\|$ year; ex-smoker = quitting smoking for at least 1 year before the start of the studid: $\mathbb{N S}=$ not significant.

\section{Sputum induction and processing}

Sputum was induced as reported by Keatings and coworkers ${ }^{6}$. In short, subjects inhaled $3 \%$ hypertonic saline, nebulized via an ultrasonic nebulizer (NEB2000, TEFA-Portanje, Woerden, The Netherlands) during three 7 -minute periods. To minimize saliva contamination, subjects were instructed to mouthwash thoroughly with saline solution before expectoration. All subjects included in this study tolerated the procedure of sputum induction well and an adequate specimen of sputum could be collected in every participant. The collected sputum was pooled and kept at $4^{\circ} \mathrm{C}$ for not more than 2 hours prior to further processing.

The volume of the pooled sputum (without selection of sputum plugs) was recorded and processed with dithiothreitol (DTT; Sputolysin, Calbiochem, La Jolla, $\mathrm{CA}$; final concentration $0.1 \%$ ) as described". The total cell count and cell viability were assessed using a standard haemocytometer (Coulter Z1, Coulter Electronics, Mijdrecht, The Netherlands) and by trypan blue exclusion, respectively. Differential cell counts (May-Grünwald Giemsa method) were carried out by one observer blinded to the clinical characteristics, counting 500 nucleated cells. The numbers of squamous cells were subtracted and the differentiall cell counts were expressed as corrected percentages. A sample was considered adequate if the slides contained $\leq 15 \%$ squamous epitheliall cells. 
Table 2. Total and differential cell counts in patients with COPD and healthy smokers

\begin{tabular}{|c|c|c|c|}
\hline & $\begin{array}{l}\text { COPD } \\
(n=78)\end{array}$ & $\begin{array}{l}\text { Healliy Smokers } \\
\qquad(n=17)\end{array}$ & p Value \\
\hline Total cell count, $10^{\text {f }}$ cellis/mi & $4.0 \pm 3.3$ & $4.0 \div 4.1$ & NS \\
\hline Viablity, \% & $90.3 \pm 7.6$ & $90.3 \pm 10.0$ & $\mathrm{NS}$ \\
\hline AW; $\%$ & $17.1 \pm 10.9$ & $36.1 \pm 15.9$ & $<0.001$ \\
\hline PHAN, \% & $80.5 \pm 124$ & $624 \div 16.4$ & 0.001 \\
\hline $\mathrm{Eos} \%$ & $1.8 \pm 3.6$ & $0.7 \pm 1.0$ & WS \\
\hline Lum, 8 & $0.7 \pm 1.2$ & $0.9 \pm 0.8$ & MS \\
\hline
\end{tabular}

* Data are presented as means \pm SD; ${ }^{\prime}$ ANONA adjusted for age, gender, and pack-years. COPD $=$ chronic obstructive pumonary disease; $\mathrm{AM}=$ alveolar macrophages; $\mathrm{PMN}=$ neutrophils; $E 0 \mathrm{~s}=$ eosinophils; $L y m=$ lymphocytes; $N S=$ not significant.

\section{Analysis of MMP-1, MMP-8, and MMP-9 activity in sputum}

Immunocapture activity assays. MMP-1, MMP-8 and MMP-9 activity assays (Amersham Biosciences, Buckinghamshire, UK) were performed according to the supplier's recommendations. These assays measure both active (mature) MMP as well as total MMP (already active plus activatable (latent) pro-MMP) activity. In brief, MMP-1, MMP-8, or MMP-9 were captured by a specific antibody immobilized on a microtiter plate. The amount of active MMP was measured directly by incubation of the captured MMP with modified pro-urokinase (UKcol), and subsequent activation of UKcol was quantified by a chromogenic substrate (S2444). Colour development was recorded at $405 \mathrm{~nm}$ at different time intervals. The amount of total MMP activity was measured through activation of the latent pro-MMP by pre-incubation with $0.5 \mathrm{mM}$ p-aminophenylmercuric acetate (APMA) for $2 \mathrm{~h}$ at $37^{\circ} \mathrm{C}$ before addition of modified pro-urokinase and chromogenic substrate. Activity is expressed in arbitrary units: $\Delta A_{504}{ }^{*} 1000 / t^{2}$. The lower detection limits were 0.5 units for MMP-1 and 1.5 units for MMP-8 and MMP-9.

DTT effect. In order to study the effect of DTT on both types of MMP assays, standard curves of appropriate recombinant proteins were incubated with $0.1 \%$ DTT (Sputolysin) under the same conditions as sputum samples during processing (20 min at room temperature). Presence of DTT did not affect MMP activities, indicating that DTT had no effect on the immunocapture activity assays used in this study (data not shown).

\section{Immunohistochemistry for MMP-8, MMP-9 on sputum cytospin}

Cytospins were fixed in acetone and stored at $-20^{\circ} \mathrm{C}$ until use. Cytospins were rehydrated in phosphate-buffered saline, $\mathrm{pH} 7.4$ and endogenous peroxidase was quenched with $0.3 \% \mathrm{H}_{2} \mathrm{O}_{2}$ in methanol. Cytospins were stained with rabbit antihuman MMP-8 polyclonal antibody or rabbit anti-human MMP-9 polyclonal antibody (TNO Gaubius, Leiden, The Netherlands). After washing, biotinconjugated donkey anti-rabbit lgG antibody (Amersham Biosciences, Buckinghamshire, UK) was applied as the secondary detection antibody, followed by ABComplex/HRP (Avidin-biotinylated horseradish peroxidase; DAKO, Glostrup, Denmerk) Enzymatic reactivity was visualized with NovaRed (Vector Laboratories, Burlingame, USA). Cytospins were counterstained with hematoxylin and mounted. No significant staining was detected in slides incubated with a control antibody 
instead of the primary detecting antibody, indicating the absence of significant background staining.

\section{Statistical analysis}

Results are presented as mean \pm standard deviation (SD) for normally distributed variables and median (range) otherwise. Groups were compared by analysis of covariance adjusted for age, gender, or pack-years where appropriate. The MannWhitney $U$ test was used to compare non-parametric data. Categorical variables were compared by the Chi-square test. Correlations between parameters were evaluated using Pearson's rank correlation analysis (Statistical Package for the Social Sciences, version 10.0.7 for Windows, SPSS Inc., Chicago, IL). A p-value below 0.05 was considered statistically significant.

\section{RESULTS}

\section{Subject characteristics}

Patients in the COPD group showed mild-to-moderate airflow obstruction, whereas healthy smokers had normal $\mathrm{FEV}_{1}$ values (percentage predicted) according to the selection criteria (Table 1). Sputum characteristics are shown in Table 2. The degree of airflow limitation (FEV, percentage predicted) correlated strongly with the percentage of neutrophils $(r=-0.576, p=0.016)$ in COPD patients, but not in healthy smokers.

Table 3. Characterization of MMP activities in sputtum of patients with COPD and healthy smokers*

\begin{tabular}{lccccc}
\hline & \multicolumn{3}{c}{ COPD } & \multicolumn{3}{c}{ Healthy Smokers } & \\
\cline { 2 - 6 } & Number & Percentage & Number & Percentage & p Value \\
\hline Total MMP-1* & $9 / 17$ & $(53)$ & $5 / 16$ & $(31)$ & NS \\
Total MMP-8 & $13 / 17$ & $(76)$ & $10 / 17$ & $(59)$ & NS \\
Total MMP-9 & $17 / 17$ & $(100)$ & $16 / 17$ & $(94)$ & NS \\
Active MMP-1 & $2 / 17$ & $(12)$ & $2 / 15$ & $(13)$ & NS \\
Active MMP-8 & $6 / 17$ & $(35)$ & $1 / 17$ & $(6)$ & $<0.05$ \\
Active MMP-9 & $13 / 17$ & $(76)$ & $7 / 17$ & $(41)$ & $<0,05$ \\
\hline
\end{tabular}

* Lower detection levels: MMP-1 0.5U; MMP-8 1.5U; MMP-9 1.5U' Chi-square test. COPD = chronic obstructive pulmonary disease: MMP = Matrix metalloproteinase; NS = not significant; $U=$ arbilrary units $\left(\Delta A_{504} * 11000 / t^{2}\right)$.

\section{Quantitative measurement of MMP activity in sputum}

Activities for MMP-9 (gelatinase B), MMP-1 and MMP-8 (collagenases) were measured by specific activity assays that are able to distuingish active and activatable enzyme (pro-enzyme) in two separate steps. MMP-9 activities were found in both COPD patients and controls. Total MMP-9 activity was significantly higher in the COPD group when compared to the control group (Figure 1, $\mathrm{p}<0.05$ ) and active MMP-9 was found $76 \%$ of the COPD patients compared to $41 \%$ of the healthy smokers (Table $3, p<0.05$ ).

Activities of the individual MMP collagenases were highly variable. Total MMP1 activity was similar and low in both groups, and in a small minority of both 
A

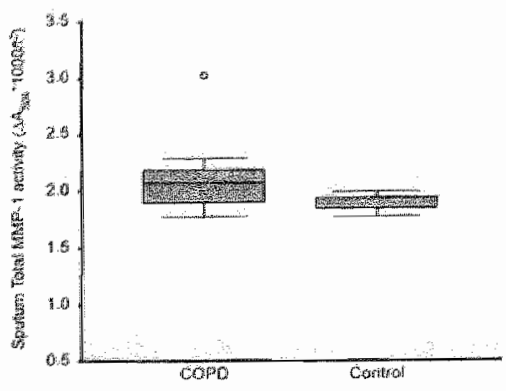

B

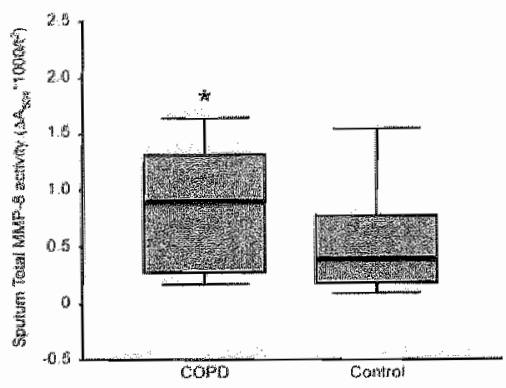

C

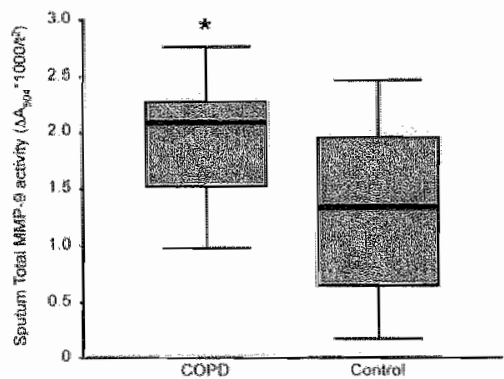

D

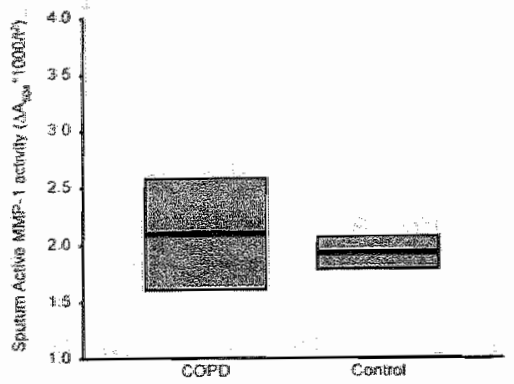

$\mathrm{E}$

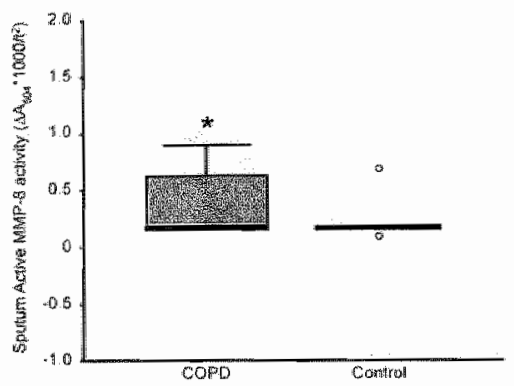

$\mathrm{F}$

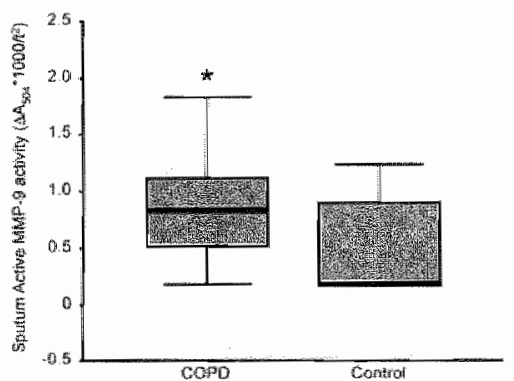

Figure 1. Levels of (a) total matrix metalloproteinase (MMP)-9, (b) total MMP-8, (c) total MMP-1, (d) active $M M P-9$, (e) active MMP-8, and (f) active MMP-1 in induced sputum abtained from patients with chronic obstructive pulmonary disease (COPD) and healthy smokers (HS). MMP activity was measured using specific immuno-capture assays. ${ }^{\circ}$ symbolizes outliers. * $P<0.05$ versus HS.

COPD patients and healthy smokers active MMP-1 (12\% and $13 \%$ respectively) was detected. Alternatively, total MMP-8 activity was significantly higher in the COPD group (Figure 1, $p<0.05$ ) and active MMP-8 was found in $35 \%$ of the COPD patients compared to $6 \%$ of the controls (Table $3, \mathrm{p}<0.05$ ).

Correlations between sputum MMP-8 and MMP-9 activity, inflammatory cells, and the FEV

The active form and total activity of each MMP examined were highly correlated in both study groups. In addition, MMP-8 and MMP-9 were strongly correlated with each other, but not with MMP-1 (data not shown). A significant correlation 
between both active and total MMP-8 and MMP-9 activity with the absolute number of neutrophils was observed in the sputum of COPD patients (Table 4). A similar correlation was noted in the healthy smokers, albeit that active MMP-8 was only detectable in one healthy smoker, and in contrast to the COPD patients, active MMP-9 and total MMP-9 activity were positively correlated to the absolute number of marcophages in sputum of healthy smokers (Figure 2).

Table 4. Conrelations between sputum MMP activity and neutrophils in patients with COPD and healthy smokers ${ }^{*}$

\begin{tabular}{lcccc}
\hline & \multicolumn{2}{c}{ COPD $(n=18)$} & \multicolumn{2}{c}{ Healthy Smokers $(n=17)$} \\
\cline { 2 - 5 } & R Value & $p$ Value & R Value & p Value \\
\hline Total MMP-8/neutrophils & 0.671 & 0.003 & 0.558 & 0.020 \\
Active MMP-8/neutrophils & 0.646 & 0.005 & -0.046 & NS \\
Total MMP-9/neutrophils & 0.673 & 0.003 & 0.720 & 0.001 \\
Active MMP-9/neutrophils & 0.698 & 0.002 & 0.707 & 0.002 \\
\hline
\end{tabular}

- Pearson's rank correlation. COPD = chronic obstructive pulmonary disease; MMP = matrix metalloproteinase; $N S=$ not significant.

In addition, the relationship between MMP activities and the degree of airflow obstruction was explored. We found that sputum activity of MMP-8 (lactive MMP. 8] $\mathrm{r}=-0.356, \mathrm{p}=0.042$; [total MMP-8] $\mathrm{r}=-0.397, \mathrm{p}=0.022$ ) and MMP-9 ([active MMP-9] $r=-0.337, p=0.055$; [total MMP-9] $r=-0.433, p=0.012$ ) were positively related to the degree of airflow obstruction for the complete study group. The correlations between MMP activities and airflow obstruction in the separated groups, however, failed to reach statistical significance.
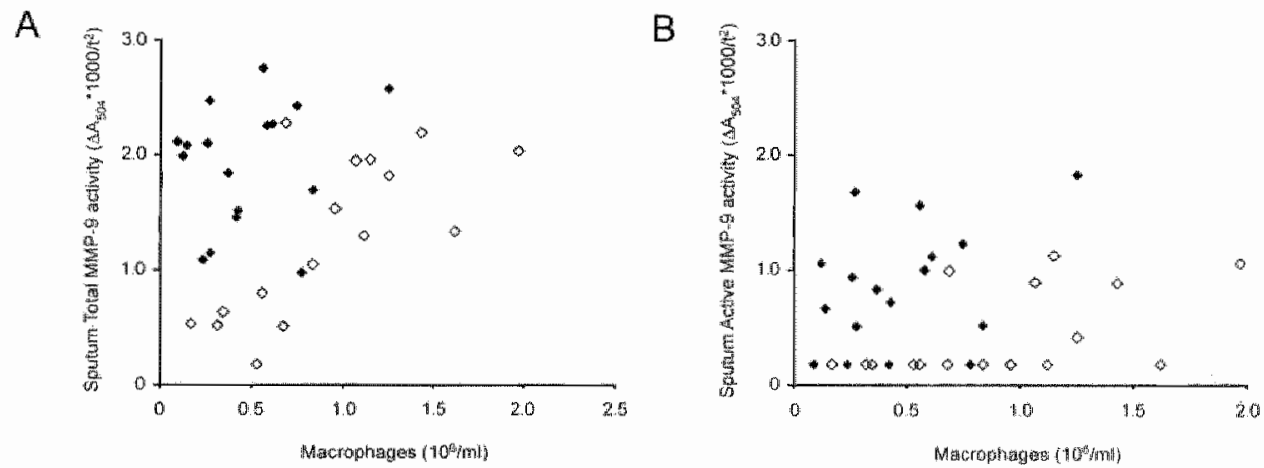

Figure 2. Correlation between macroplqages numbers $\left(10^{\circ} / \mathrm{ml}\right.$ sputum) and sputum levels of (a) lotal matrix metalloproteinase (MMP)-9 activity (COPD: $r=0.197, p=0.448$; control: $r=0.711, p=0.002$ ) or (b) active MMP-9 (COPD: $r=0.373, p=0.141$; control: $r=0.519, p=0.040$ ) in patients with chronic obstructive pulmonary disease ( $)$ ) and healthy smokers (0).

\section{MMP immunohistochemistry on cytopins}

Immunohistochemistry on cytospins of sputum cells was performed to determine the cellular distribution of MMP-8 and MMP-9. As shown in Figure 3, strong positive staining for MMP-9 was observed in both alveolar macrophages and neutrophils, whereas immunoreactivity against MMP-8 was exclusively found in 
neutrophils: In addition, squamous epithelial cells (Figure 3), eosinophils and lymphocytes, recognized on basis of morphology, and bronchial epithelial cells were negative for MMP-8 and MMP-9 (not shown).
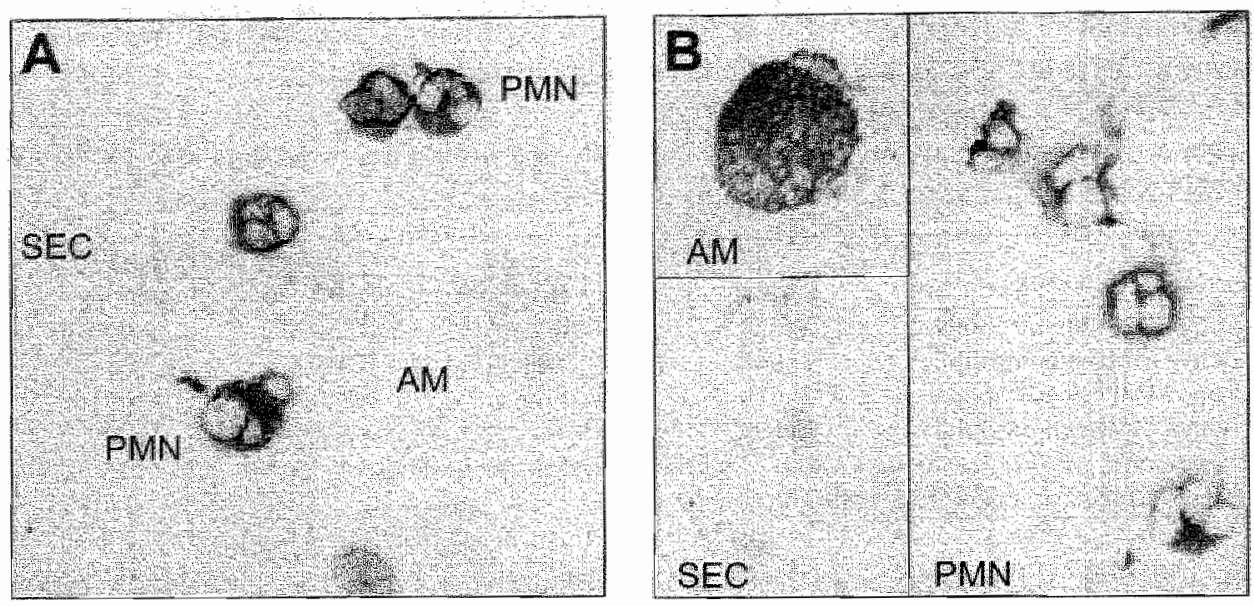

Figure 3. Immunolistochemistry for (A) MMP-B and (B) MMP-9 on cytospins of sputum cells. Note the strong positive staining for MNP-8 in neutrophis (PMN) and for MMP-9 in both macrophages (AM) and netutrophils. Staining for MMP-8 and MMP-9 was absent in squamous epithelial cells (SEC). Results are representative for both COPD patients and healthy smokers.

\section{DISCUSSION}

MMP activity represents a highly controlled process involving regulation of proenzyme expression and secretion, proteolytic activation of the pro-enzyme and (irreversible) inhibition by specific inhibitors. Specific ELISAs have the disadvantage that information on the active/inactive state of the proteinases is lost. Alternatively, the use of zymograms is elaborate, semi-quantitative, and does not differentiate between the active proteinase and proteinase-inhibitor complexes. In this study, we used specific immuno-capture assays that allow determination of both active as well as total (active and latent) MMPs in human body fluids and thus address the complex interaction between activation and inhibition of MMP activity. In these assays, specificity is achieved through capturing of the targeted proteinase by a specific antibody and the activity of the immobilized proteinase is subsequently assessed by proteolytic activation of a modified urokinase. The assay is insensitive to MMP-inhibitor complexes. Pro-MMP (latent) forms are measured through activation of the captured pro-enzyme through a mercury salt that allows determination of the potentially activatable proteinases.

In this paper, we studied MMP gelatinase and collagenase activity in induced sputum of patients with mild-to moderate COPD and healthy smokers. MMP-8 and MMP-9 activities were both increased in COPD patients versus healthy smokers, whereas low MMP-1 activities were present in both study groups. In 
addition, net MMP-8 and MMP-9 activity was found in a number of healthy smokers and a significantly higher proportion of the COPD patients. Presence of active forms is an uncommon finding in biological fluids. Active MMPs are commonly associated with cellular activation under pathological circumstances and are therefore indicative of a proteinase-anti-proteinase imbalance. Presence of active MMP-8 and MMP-9 in both study groups may relate to smoking behaviour as cigarette smoke-conditioned culture medium has been shown to be potent cell stimulus. It is tempting to speculate that lipopolysaccharide present in cigarette smoke is responsible for the proteolytic dysbalance in smokers and to a greater extent in the COPD patients".

These findings extend previous findings demonstrating increased MMP-9 concentrations (ELSA) in induced sputum of patients with chronic bronchitis ${ }^{20,21}$ and non-quantitative zymographic findings demonstrating MMP-9 in BAL fluid of COPD patients ${ }^{13,14,22}$. Presence of active MMP-8 in induced sputum confirms the presupposition of Finlay and coworkers that MMP-8 constitutes the prime interstitial collagenase in emphysema ${ }^{22}$.

In contrast to MMP-8 and MMP-9, we found relative low MMP-1 activities in induced sputum samples of COPD patients representing the airway compartment ${ }^{23}$. This observation apparently contrasts with the increased expression of MMP-1 in the alveolar compartment of patients with late stage emphysema ${ }^{12}$. We suggest that these findings reflect spatial differences in MMP expression between the alveolar compartment and the airway compartment, but we cannot exclude that the proteinase profile changes during progression of the disease.

Our observation that activity of MMP-8 and MMP-9 correlates positively with neutrophil numbers in both study groups, suggests that MMP-8/MMP-9 activity in sputum originates from activated neutrophils. Neutrophils are thought to play an important role in the chronic inflammatory reaction present in the airways of COPD patients. In line with previous observations, a significant increase in neutrophils (percentage) was found in induced sputum of COPD patients versus healthy smokers, which highly correlated with the degree of airlow limitation ${ }^{4,6,24,25}$. As sputum samples were centrifuged prior to freezing sputum to obtain cell free supernatants, the increased MMP-8 and MMP-9 activity in COPD sputum reflects enhanced MMP secretion rather than a proteinase release during freezing and thawing of the samples. This notion is supported by the finding of active forms in a higher proportion of the COPD patients. Herewith in line, complexes of human neutrophil lipocalin (HNL)/MMP-9 in BAL fluid of subjects with subclinical emphysema also suggest that MMP-9 present in BAL fluid is derived from neutrophils ${ }^{14}$.

Using immunohistochemical techniques on cytospins of sputum derived cells, we found a strong positive signal for MMP-9 in both neutrophils and alveolar macrophages, whereas other cell types like eosinophils, lymphocytes, bronchial epithelial cells, and squamous epithelial cells were negative. These results confirm the prominent role of alveolar macrophages and neutrophils in COPD as major source of MMP-9. Recent studies performing in vitro stimulation of alveolar macrophages isolated from BAL fluid demonstrated that these cells are a 
significant source of MMP-9 in the airways of subjects with $\mathrm{COPD}^{2,26}$. Alveolar macrophages from COPD patients were shown to release more MMP-9, and it is more active, than released from alveolar macrophages of healthy smokers and non-smoking individuals ${ }^{26}$. Positive staining for MMP-8 was exclusively observed in neutrophils and not in other cell types present in sputum, which is consistent with the literature, as MMP-8 has been labeled as neutrophil collagenase ${ }^{16,17}$.

Presence of increased MMP-8 and MMP-9 activity in the airways of mild-tomoderate COPD patients supports the concept of an impaired proteinase-antiproteinase balance. In COPD, a MMP imbalance in the airways may account for inappropriate matrix remodeling and basement membrane disruption in both the upper and lower respiratory tract. Moreover, excess MMP activity may also contribute to the chronic inflammatory response and interfere with tissue repair through its effects on a variety of non-matrix proteins, including cytokines, chemokines, integrins, antimicrobial peptides, and other proteinases. Clearly, the precise mechanisms involving MMPS and their inhibitors in matrix remodeling and chronic inflammation in COPD, as well as their consequences in terms of abnormality of lung function require further investigations.

In summary, COPD patients had significantly higher levels of active as well as total (activatable) MMP-8 and MMP-9 in their sputum as compared to healthy smokers, whereas activity of MMP-1 was not increased. In both study groups, activity of MMP-8 and MMP-9 (active and total) showed a strong correlation with each other, and with absolute numbers of neutrophils. In addition, an inverse correlation between MMP-8 and MMP-9 activity in sputum and airflow obstruction $\left(\mathrm{FEV}_{b}\right)$ was found when values of the two study groups were combined. Immunohistochemistry demonstrated strong positive staining for MMP-9 in both alveolar macrophages and neutrophils, whereas specific staining for MMP-8 was only observed in neutrophils. The presence of increased MMP-8 and MMP-9 activity in the airways of mild-to-moderate COPD patients supports the concept of an impaired proteinase-anti-proteinase balance in COPD.

\section{ACKNOWLEDGEMENTS}

The authors wish to thank Natascha van Lent and Adri Mulder for excellent technical help with the immunocapture activity assays and immunohistochemistry, respectively, and Dr. A.M.W.J. Schols for expert assistance with the statistical evaluation of the data. This study was supported by a grant from Glaxo Wellcome, The Netherlands.

\section{REFERENCES}

1. Pauwels RA, Buist AS, Calverley PM, lenkins $\mathrm{CR}$, and Hurd SS. Global strategy for the diagnosis, management, and prevention of chronic obstructive pulmonary disease. NHLBIWHO Global Initiative for Chronic Obstructive Lung Disease (GOLD) Workshop summary. An I Respir Crit Care Med $2001: 163: 1256-1276$ 
2. Finkelstein $\mathrm{R}$, Fraser $\mathrm{RS}$, Gherzo $\mathrm{H}_{\text {, }}$ and Cosio MG. Aveolar inflammation and its relation to emphysema in smokers. Am / Respir Crit Care Med 1995;152:1666-1672.

3. Saetta $M$, Di Stefano $A$, Turato $G$, Facchini $M$, Corbino L, Mapp CE. Maesirell P, Ciaccia $A$, and Fabbri LM. CD8 + T-lymphocytes in peripheral airways of smokers with chronic obstructive pulmonary disease. Am / Respir Crit Care Med 1998;157:822-826.

4. Peleman RA, Rytila PH; Kips JC, Joos GF, and Pauwels RA. The cellular composition of induced sputum in chronic obstructive pulmonary disease. Eur Respir/ 1999;13:839-8343.

5. Pesci $A$, Balbi $B$, Majori $M$, Cacciani $G$, Bertacco $S$, Alciato $P$, and Donner $C F$. Intlammatory cells and mediators in bronchial lavage of patients with chronic obstructive pulmonary disease. Eur Respir / 1998; 12:380-386.

6. Keatings $\mathrm{VM}_{*}$ Collins $\mathrm{PD}$, Scott $\mathrm{DM}$, and Barnes Pl. Differences in intertleukin-8 and tumor necrosis factor-alpha in induced sputum from patients with chronic obstructive pumonary disease or asthma. Am / Respir Crit Care Med 1996;153:530-534.

7. OShaughnessy TC, Ansari TW, Barnes NC, and fleffery PK. Inflammation in bronchial biopsies of subjects with chronic bronchillis: inverse relationship of CD8 + T lymphocytes with FEV1. Am J Respir Crit Care Med 1997;155:852-857.

8. Vernooy $J H]_{\text {, Küçükaycan } M}$, Jacobs $J A$, Chavannes NH, Buurnan WA, M.A. D, and E.F.M. W. Local and Systemic Inflammation in Patients with Chronic Obstructive Pullmonary Disease: Solluble Tumor Necrosis Factor Receptors are Increased in Sputum. Am / Respir Corit Care Med 2002;166:1218-1224.

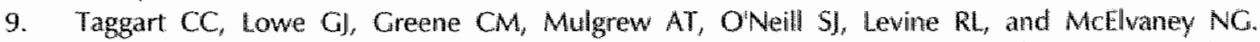
Cathepsin B, L, and S cleave and inactivate secretory leucoprotease inhibitor. I Biol Chem $2001 ; 276: 33345-33352$.

10. Vandivier RW, Fadok VA, Hoffmann PR, Bratton DL, Penvaril C, Brown KK, Brain JD, Accurso FJ, and Henson PM. Elastase-mediated phosphatidyserine receptor cleavage impairs apoptotic cell clearance in cystic fibrosis and bronchiectasis. / Clin Invest 2002;109:669-670,

111. Ohnishi $K_{x}$ Takagi $M$, Kurokawa $Y$, Satomi $S$, and Konttinen $Y T$. Matrix metalloproteinasemediated extracellular matrix protein degradation in human pulmonary emphysema. Lab invest $1998 ; 78: 1077-1087$.

12. Imaï $K$, Dalal SS, Chen ES, Downey R, Schulman LL, Ginsburg M, and D'Armiento J. Human collagenase (matrix metalloproteinase-1) expression in the lungs of patients with emphysema. Am J Respir Crit Care Med 2001;163:786-791.

13. Segura-Valdez L, Pardo $A$, Gaxiola $M$, Uhal BD, Becerril $C$, and Selman M. Upregulation of gelatinases $A$ and $B$, collagenases 1 and 2 , and increased parenchymal cell death in COPD. Chest $2000 ; 117: 684-694$.

14. Betsuyaku T, Nishimura $M$, Takeyabu K, Tanino $M$, Venge $P$, Xu $S$, and Kawakami $\gamma$. Neutrophil granule proteins in bronchoalveolar lavage fluid from subjects with subdinical emphysema. Am J Respir Crit Care Ned 1999;159:1985-1991.

15. Zheng $T$, Zhu $Z$, Wang $Z$, Homer RJ, Ma B, Riese RJ, Jr., Chapman HA, Jr., Shapiro 5D, and Elias $J A$. Inducible targeting of $1 \mathrm{~L}-13$ to the adult lung causes matrix metalloproteinase- and cathepsindependent emplyseman / Clin lowest 2000;106:1081-1093.

16. Handbook for proteolytic enzymes. 1998. . 0 A.J. Barret, N.D. Rawlings, and F. Woossner, teditors. ed. Academic Press, London, UK.

17. Parks WC, and Shapiro SD. Matrix metalloproteinases in lung biology. Respir Res 2001;2:10-19.

18. ATS. Standards for the diagnosis and care of patients with chronic obstructiwe pulmonary disease. Am / Respir Crit Care Med 1995:152:577-121.

19. Hasday JD, Bascom R, Costa J), Fitzgerald T, and Dubin W. Bacterial endotoxin is an active component of cigarette smoke. Chest 1999;115:B29-835.

20. Vignola $\mathrm{AM}$, Riccobono 1 , Mirabella $A$, Profita $M$, Chanez $P$, Bellia $V$, Mautino $G$, DAccardi $P$, Bousquell $J$ and Bonsignore $C$. Sputum metalloproteinase. $9 /$ tissue inhibitor of metalloproteinase. 1 ratio correlates with airflow obstruction in asthma and chronic bronchitis. Am / Respir Crit Care Med 1998;158:1945-1950.

21. Cataldo $D$, Munaut $C_{x}$ Noel $A_{f}$ Frankenne F, Bartsch P, Foidart JM, and Louis R. MMP-2- and MMP-9-linked gelatinolytic activity in the sputum from patients with asthma and chronic obstructive pulmonary disease. Int Arch Allergy Imomunol 2000;123:259-267. 
22. Finlay CA, Russell KJ, MCMahon KJ, DArcy EM, Masterson JB, FitzCerald MX, and O'Connor CM. Elevated levels of matrix metalloproteinases in bronchoalveolar lavage fluid of emphysematous patients. Thorax 1997,52:502-506.

23. Alexis NE, Hu SC, Zeman $K$, Alter $T$, and Bennett WD. Induced Sputurm Derives from the Central Airways. Confirmation using a radiolabeled aerosol bolus delivery technique. An / Respir Crit Care Med 2001;164:1964-1970.

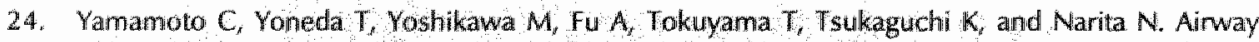
inflammation in COPD assessed by sputum levels of interleukin 8. Chest 1997;112:505-510.

25. Rutgers $\mathrm{SR}$, Timens W, Kaufmann HF, wan der Mark $\mathrm{TW}$, Koeter $\mathrm{GH}$, and Postiva DS Comparison of induced sputum with bronchial wash, bronchoalveolar lavage and bronchial biopsies in COPD. Eur Respir J 2000:15:109-115.

26. Russell RE, Culpitt SV, DeMatos, $C$, Donnelly $L$, Smith M, Wiggins $]$, and Barnes PJ. Rellease and activity of matrix metalloproteinase- 9 and tissue inhibitor of metalloproteinase-1 by allveolar macrophages from patients with chronic obstructive pulmonary disease. An J Respir Cell Mol Biol $2002 ; 26: 602-609$. 


\title{
CHAPTER 7
}

\section{Intratracheal instillation of lipopolysaccharide in mice induces apoptosis in bronchial epithelial cells: no role for TNF- $\alpha$ and infiltrating neutrophils}

Juanita H.J. Vernooy', Mieke A. Dentener", Robert Jan van Suylen², Wim A. Buurman $^{3}$, and Emiel F.M. Wouters ${ }^{1}$

Departments of ${ }^{1}$ Respiratory Medicine, ${ }^{2}$ Pathology and ${ }^{3}$ General Surgery, University Hospital Maastricht, Maastricht, The Netherlands

American Journal of Respiratory Cell and Molecular

Biology 2001;24: 569-576

\begin{abstract}
This study investigated apoptosis in lungs after local exposure to lipopolysaccharide (LPS). Mice were instilled intratracheally with $5 \mu \mathrm{g}$ LPS, which corresponds to the amount acquired by smoking approximately 25 cigarettes, and killed at different time points after exposure. Our data demonstrate that local LPS exposure resulted in apoptosis in lungs from $2 \mathrm{~h}$ and peaked at $24 \mathrm{~h}$, as detected by ligation-mediated polymerase chain reaction. Morphologic examination and terminal deoxynucleotidyl transferase-mediated deoxyuridine triphosphate nickend label staining demonstrated apoptosis in bronchial epithelial cells early after intratracheal (IT) LPS challenge, whereas infiltrating neutrophils displayed positive staining at 24 and $72 \mathrm{~h}$ after exposure. Apoptosis in lungs clearly preceded pulmonary neutrophil infiltration, confirming that neutrophils did not contribute to pulmonary apoptosis at early time points. Further, using three experimental approaches namely, anti-tumor necrosis factor (TNF)- $\alpha$ treatment, IT TNF- $\alpha$ instillation, and TNF/lymphotoxin- $\alpha$ knockout mice we demonstrate that TNF $\alpha$, which was ellevated in lungs at both messenger RNA and protein levels after IT LPS challenge, was no primary mediator in LPS-induced apoptosis at early time points. Thus, local LPS exposure in mice resulted in early apoptosis of bronchial epithelial cells independent of infiltrating neutrophils and TNF- $\alpha$, which suggests that apoptosis of bronchial epithelium may be involved in airway injury during exposure to LPS.
\end{abstract}




\section{INTRODUCTION}

Lipopolysaccharide (LPS) is a major pathogenic factor in Gram-negative sepsis, which is characterized by shock, coagulopathy, and multiorgan dysfunction. In response to systemic LPS exposure, proinflammatory cytokines such as tumor necrosis factor (TNF)- $\alpha$, interleukin (IL)-1B, and interferon- $\gamma$ are produced by the host, which have been shown to either directly or indirectly mediate many of the hemodynamic and inflammatory changes and organ damage in sepsis. Animal models of septic shock indicated that apoptosis, an active cellular process of cell death under genetic control, contributed to primary organ damage. Systemic LPS administration in mice resulted in apoptotic cell death in the endothelium of several tissues, including intestine and lung ${ }^{1 \cdot 3}$. In vivo blocking of TNF- $\alpha$ by antiTNF antibody ${ }^{1}$ or TNF-binding protein $s^{2}$ attenuated LPS-induced apoptotic rates, suggesting that TNF- $\alpha$ is the primary mediator in endothelial apoptotic cell death induced by systemic administered LPS.

The respiratory system is continuously exposed to low levels of LPS, which is ubiquitously present as a contaminant on airborne particles, including air pollution ${ }^{4}$, organic dusts ${ }^{5}$, and cigarette smoke ${ }^{6}$. Exposure to high LPS levels for example, agricultural workers in contact with organic dusts, or heavy smokers is known to provoke acute lung inflammation, partly initiated via the early endogenous induction of $\mathrm{LL}-1 \mathrm{~B}$ and TNF- $\alpha$ in the lung. These cytokines are thought to contribute to the pathogenesis of acute inflammation by inducing the expression of endothelial leukocyte adhesion molecules and chemokines, consequently leading to recruitment of neutrophils into alveoli. Neutrophils play a prominent role in the host defense against pathogens, but are also considered to be responsible for pulmonary injury, manifested by increased lung vascular permeability, edema, and cell death ${ }^{7}$. Neutrophil presence was suggested to induce apoptotic cell death in primary human bronchial epithelial cells $s^{3}$. In vitro studies directed at resolving tissue injury caused by LPS have indicated that LPS can directly trigger pulmonary cells to undergo apoptosis. Bingisser and coworkers showed that LPS induced apoptosis in human alveolar macrophages dose-dependently ${ }^{9}$. In addition, LPS was reported to cause apoptotic cell death in primary cultures of isolated bovine and sheep pulmonary artery endothelial cells, and in a bovine pulmonary artery endothelial cell line ${ }^{10,11}$.

In view of the continuous exposure of the lungs to LPS, we studied whether local exposure to LPS in vivo results in apoptotic cell death in lungs. To this end, mice were instilled intratracheally with LPS, and apoptotic cell death in lung tissue was assessed via ligation-mediated (LM) polymerase chain reaction (PCR) and terminal deoxynucleotidyl transferase-mediated deoxyuridine triphosphate nickend label staining. In this study we show for the first time that local LPS exposure results in apoptotic cell death in bronchial epithelial cells at early time points after exposure. In addition, we investigated the role of infiltrating neutrophils and TNF$\alpha$ in LPS-induced apoptosis and demonstrate that neither neutrophils nor TNF- $\alpha$ mediate apoptotic cell death in lungs at early time points. 


\section{MATERIAL \& METHODS}

\section{Animals}

Male Swiss mice (30 to $40 \mathrm{~g})$ were obtained from Charles River Breeding Laboratories (Heidellberg, Germany). Animals were housed individually in standard laboratory cages and allowed food and water ad libitum throughout the experiments. The studies were carried out under a protocol approved by the Institutional Animal Care Committee of Maastricht University.

Male TNF/lymphotoxin (LT)- $\alpha$ double knockout $(-/-)$ and wild type $(+/+)$ mice were obtained from Dr. H. P. Eugster (Universïty Hospital Zurich, Department of Internal Medicine, Zurich, Switzerland ${ }^{12}$ ). These mutant mice were bred at the Laboratory of Molecular Biology, University of Gent (Gent, Belgium) according to the Belgian and European Union guidelines for the use and care of laboratory animals. The experiments were performed in Gent under a protocol approved by the Institutional Animal Care Committee of the University of Cent.

\section{Experimental protocol}

Intratracheal (IT) instillation technique was performed according to Starcher and Williams $^{13}$. A control experiment was performed in which bromothymol blue dissolved in $50 \mu 10.9 \% \mathrm{NaCl}$ was instilled in mice to check distribution of solution in the lung. Macroscopic and microscopic analysis demonstrated that blue marker dye had spread throughout the whole lung. Mice ( $n=6$ per group) were anesthetized by intraperitoneal (IP) injection of $3 \mathrm{mg} / \mathrm{kg}$ xylazine (Sedamun, AUV Cuijk. The Netherlands) and $75 \mathrm{mg} / \mathrm{kg}$ ketamin (Nimatek, AUV Cuijk, The Netherlands). LPS (Escherichia coli, serotype O55:B5, Sigma, St. Louis, MO) dissolved in $50 \mu \mathrm{l}$ sterile $0.9 \% \mathrm{NaCl}$ was instilled intratracheally via al canule, followed by $0.15 \mathrm{ml}$ of air. The dose of LPS used was $5 \mu \mathrm{g} / \mathrm{mouse}$, which corresponds to the LPS dose delivered to the human lung by smoking approximately 25 cigarettes $^{6}$. No signs of an overall toxic effect of the dose of LPS used were observed in the trachea, airways, and lungs, either in this study or in those by others ${ }^{14,15}$. Sham mice were instilled intratracheally with $50 \mu \mathrm{LPS}$-free

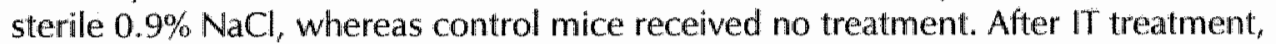
the mice were kept in an upright position for $10 \mathrm{~min}$ to allow the fluid to spread throughout the lungs. Mice were killed at $2,4,8,24$, or $72 \mathrm{~h}$ after instillation, and blood was collected by heart puncture. After thoracotomy, lungs were prepared for bronchoalveolar lavage (BAL) or DNA extraction, RNA extraction, myeloperoxidase (MPO) analysis, and light microscopy.

TNF- $\alpha$ neutralization in vivo was accomplished by using antimurine TNF- $\alpha$ monoclonal antibody (mAb) TN3, a complementarity-determining regions-grafted murine immunoglobulin (Ig) G2a (a generous gift from Celltech, Slough, UK), which was shown to have neutralizing capacities in wivo' ${ }^{16}$. IgG class-matched control antibody ( $\operatorname{lgG} 2 \mathrm{a} \mathrm{mAb} 5 \mathrm{D} 7^{17}$ ) was used as control reagent. Administration of these reagents to mice not subjected to IT LPS instillation did not influence any of the parameters investigated (data not shown). Mice treated with anti-TNF- $\alpha$ $\mathrm{mAb}$ TN3 and control IgG2a mAb 5DT received a single IP injection of $1 \mathrm{mg}$ 
antibody in $1 \mathrm{ml}$ LPS-free sterile $0.9 \% \mathrm{NaCl}$ at $2 \mathrm{~h}$ before IT LPS instillation. At 4 or $24 \mathrm{~h}$ after LPS, mice were killed and the lungs were prepared for DNA extraction and histology.

\section{Analysis of DNA fragmentation}

Genomic DNA was isolated from snap-frozen lung tissue of the right lung using a DNA purification kit (Wizard; Promega, Madison, WI). DNA concentration and purity were ascertained by electrophoresis on an ethidium bromide-stained $0.8 \%$ agarose gel followed by ultraviolet (UV) illumination and UV spectrophotometric analysis at wavelengths of 260 and $280 \mathrm{~nm}$. DNA fragmentation in lung tissue was investigated with a commercially available LM-PCR assay kit (Apoalert; Clontech, Palo Alto, CA), enabling sensitive and semiquantitative measurement of the extent of apoptosis. Dephosphorylated adaptors (12-and 24-mer) were ligated to $500 \mathrm{ng}$ of DNA with T4 DNA ligase for $16 \mathrm{~h}$ at $16^{\circ} \mathrm{C}$. The 24-mer adaptor also served as primer in the LM-PCR, in which $25 \mathrm{ng}$ of ligated DNA was amplified under the following conditions: hot start $\left(72^{\circ} \mathrm{C}\right.$ for $\left.8 \mathrm{~min}\right)$ with Taq polymerase (PerkinElmer/Cetus, Emeryville, CA) added after $3 \mathrm{~min}, 22$ cycles $\left(94^{\circ} \mathrm{C}\right.$ for $15 \mathrm{~s}, 72^{\circ} \mathrm{C}$ for $3 \mathrm{~min})$, and postcycling $\left(72^{\circ} \mathrm{C}\right.$ for $\left.15 \mathrm{~min}\right)$. Amplified DNA was separated by electrophoresis on a 1.2\% agarose gel containing ethidium bromide and visualized by UV illumination. Intensity of the 360-base pair (bp) band was digitally analyzed (SigmaGel 1.0; SPSS, Chicago, IL) and expressed in arbitrary units.

\section{Histology}

After thoracotomy, the left lung was inflated with $10 \%$ phosphate-buffered formalin ( $\mathrm{pH} \mathrm{7.4)}$ at a pressure of $20 \mathrm{~cm} \mathrm{H} 2 \mathrm{O}$ through the trachea for $15 \mathrm{~min}$ and subsequently fixed in $10 \%$ phosphate-buffered formalin for $24 \mathrm{~h}$. After paraffin embedding, $4 \mu \mathrm{m}$ sections were cut and stained with hematoxylin and eosin (H\&E) for histologic analysis (Leica Microsystems, Cambridge, UK).

\section{DNA nick-end labeling of tissue sections}

Histologic aspects of apoptosis were studied by terminal deoxynucleotidyl transferase (TdT)-mediated deoxyuridine triphosphate (dUTP) nick-end labeling (TUNEL), performed according to the protocol described by Gavrieli and colleagues $^{1 \mathrm{t}}$ with slight modifications. Briefly, $4-\mu \mathrm{m}$ paraffin sections were deparaffinized and pretreated with $20 \mu \mathrm{g} / \mathrm{ml}$ Proteinase $\mathrm{K}$ (Sigma). Endogenous peroxidase was quenched with $0.5 \%$ hydrogen peroxide $\left(\mathrm{H}_{2} \mathrm{O}_{2}\right)$. Sections were incubated for $1 \mathrm{~h}$ at $37^{\circ} \mathrm{C}$ in a solution consisting of $25 \mathrm{mM}$ Tris, $200 \mathrm{mM}$ sodium cacodylate, $0.25 \mathrm{mg} / \mathrm{ml}$ bovine serum albumin (Sigma), $1.5 \mathrm{mM}$ cobalt chloride, $40 \mu \mathrm{M}$ digoxigenin-11-dUTP (Boehringer Mannheim, Mannheim, Germany), and $30 \mathrm{U} / \mathrm{ml} \mathrm{TdT}$ (Boehringer Mannheim), $\mathrm{pH}$ 6.6. The labeling reaction was terminated by transfierring the sections into $300 \mathrm{mM}$ sodium chloride $/ 30 \mathrm{mM}$ sodium citrate for $30 \mathrm{~min}$ at $37^{\circ} \mathrm{C}$. Incorporated digoxigenin-11-dUTP was demonstrated with peroxidase-conjugated sheep antidigoxigenin antibody (Boehringer Mannheim). The labeled antibody was visualized with diaminobenzidine (Boehringer Ingelheim, Heidelberg, Germany). Sections were 
lightly counterstained with hematoxylin and mounted. Negative controls included TdT-free labeling mixture. Thymus sections from the same animal senved as positive controls.

\section{Determination of MPO}

MPO was isolated from snap-frozen lung tissue of the right lung as described by Kuebler and coworkers ${ }^{19}$. Enzymatic detection of MPO was performed in a 96well plate (Greiner, Nurtingen, Germany) as previously described ${ }^{20}$. Briefly, assay mixtures consisted of $40 \mu \mathrm{l} 0.75 \mathrm{mM} \mathrm{H}_{2} \mathrm{O}_{2}$ in $80 \mathrm{mM}$ phosphate-buffered saline (PBS) (pH 5.4) and $40 \mu \mathrm{l}$ sample diluted in $50 \mathrm{mM} \mathrm{PBS} \mathrm{(pH} \mathrm{6.0)} \mathrm{and} 0.5 \%$ hexa1,6-bis-decyltrimethylammonium bromide (Sigma). The reaction was initiated by adding $20 \mu \mathrm{l}$ of $8 \mathrm{mM}$ 3,3'5,5'-tetramethylbenzidine (TMB) (Boeluringer Mannheim) in dimethyl sulfoxide (Sigma) and stopped after $15 \mathrm{~min}$ by adding 100 $\mu /$ well $1 \mathrm{M} \mathrm{H}_{2} \mathrm{SO}_{4}$. Subsequently, optical density was determined at $450 \mathrm{~nm}$. All samples were assayed in triplicate. MPO activity was calculated per milligram of lung tissue and corrected for wet/dry ratios. A titration curve of horseradish peroxidase was used for the calculation of MPO activity, which is expressed in arbitrary units.

\section{Reverse transcription/PCR}

Total RNA was isolated from snap-frozen lung tissue of the right lung using a commercially available kit (SV Total RNA Isolation System; Promega). Total RNA concentration and purity were ascertained by electrophoresis on an ethidium bromide-stained $0.8 \%$ agarose gel followed by UV illumination and UV spectrophotometric analysis at wavelengths of 260 and $280 \mathrm{~nm}$. The quantity of 5 $\mu \mathrm{g}$ of total RNA was reverse transcribed in a $20-\mu$ l volume using oligo(dT) primers and Moloney murine leukemia virus reverse transcriptase (RT) (Life Technologies, Paisley, UK) according to the supplier's recommendations. PCR for murine TNF- $\alpha$ and $B$-actin was performed in a $25-\mu \mathrm{l}$ reaction volume containing $100 \mu \mathrm{M}$ of each deoxynucleotide triphosphate, $200 \mathrm{nM}$ sequence specific primers, and $0.5 \mathrm{U} \mathrm{Taq}$ DNA polymerase (Perkin-Elmer/Cetus) during 35 cycles under the following conditions: $95^{\circ} \mathrm{C}$ for $30 \mathrm{~s}, 60^{\circ} \mathrm{C}$ for $45 \mathrm{~s}$, and $72^{\circ} \mathrm{C}$ for $30 \mathrm{~s}$. PCR primers used in RT-PCR for TNF- $\alpha$ (307 bp) and B-actin ( 348 bp) were designed as previously described $^{20}$. Amplified PCR products were analyzed on a $1.2 \%$ agarose gel containing ethidium bromide and visualized by UV illumination. A mock PCR (without complementary DNA (cDNA)) was included to exclude contamination.

\section{$B A L$}

The trachea was exposed with a midline incision and cannulated with a steel catheter. The lungs were lavaged six times with sterile $0.9 \% \mathrm{NaCl}$ at a volume of $1.5 \mathrm{ml} /$ wash. The average fluid recovery was greater than $90 \%$. The BAL fluid (BALF) was centrifuged at $1,500 \mathrm{rpm}$ for $10 \mathrm{~min}$ at $4^{\circ} \mathrm{C}$ and the supernatants were stored at $-20^{\circ} \mathrm{C}$ until analysis. 
Enzyme-linked immunosorbent assay for murine TNF- $\alpha$

TNF- $\alpha$ concentrations in BALF and plasma were determined using a specific enzyme-linked immunosorbent assay (ELISA) as described by Dentener and colleagues $^{21}$. Briefly, 96-well immuno maxisorp plates (Nunc, Roskilde, Denmark) were coated with $5 \mu \mathrm{g} / \mathrm{m}$ l hamster antimurine TNF- $\alpha \mathrm{mAb}$ (TN3; kindly provided by Celltech). Murine recombinant ( $r$ ) TNF- $\alpha$ (kindly provided by Genentech, San Francisco, CA) was used for standard titration curves. Polyclonal rabbit antimurine TNF-a (Genzyme, Cambridge, $M A$ ) was followed by peroxidase-conjugated goat antirabbit IgG (Jackson, West Grove, PA) and TMB was used as substrate. The ELISA had a lower detection limit of $50 \mathrm{pg} / \mathrm{ml}$.

\section{Statistical analysis}

Data are expressed as means \pm standard error of the mean (SEM). Statistical analysis was performed by means of Mann-Whitney $U$ test and probability values below 0.05 were considered statistically significant.

\section{RESULTS}

Induction of apoptosis in lungs after intratracheal instillation of LPS

In the present study, apoptotic cell death after IT LPS instillation was determined by ligation-mediated PCR on DNA isolated from lung tissue. As shown in Figure 1, local LPS administration resulted in induction of DNA fragmentation ladders of approximately 180-bp multimers, which are considered to be characteristic of apoptotic cell death. DNA laddering was already evident $2 \mathrm{~h}$ after LPS treatment and peaked at $24 \mathrm{~h}$ (intensity: $360-\mathrm{bp}$ band $2.7 \mathrm{U}[2 \mathrm{~h}]$ versus $24.7 \mathrm{U}[24 \mathrm{~h}]$ ). At $72 \mathrm{~h}$ after exposure, DNA laddering was strongly diminished. Little or no DNA laddering was detected in lung tissue from saline-treated and control mice. These results indicate that IT LPS instillation induced apoptosis in the lung, which was already evident at early time points.

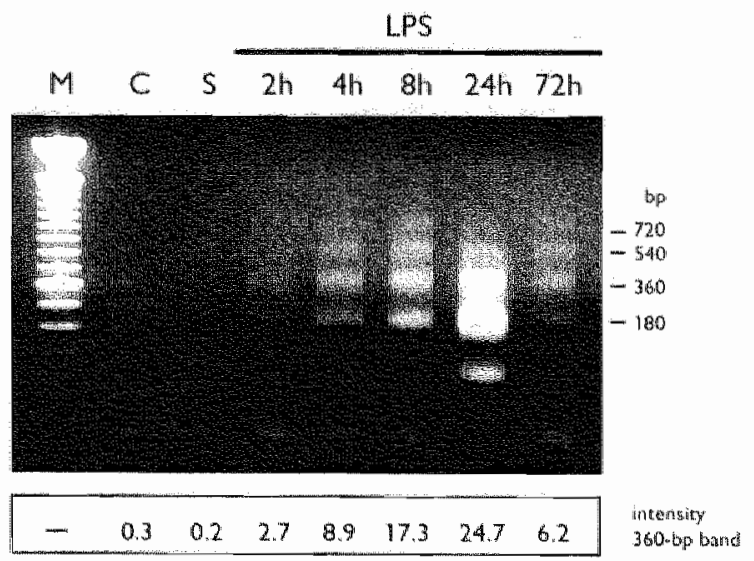

Figure 1. Induction of DNA laddering in lung tissue by IT LPS instillation. Mice received $5 \mathrm{Hg}$ of LPS IT and were sacrificed at $2,4,8,24$ and $72 \mathrm{~h}$ postexposure. Control mice (C) and saline-treated mice (S) were killed after $24 \mathrm{~h}$. DNA isolated from snapfrozen lung samples was amplified by LM-PCR and separated by electrophoresis on a $1.2 \%$ agarose gel containing ethiclium bromide. Intensity of the 360-bp band was digitally anallysed to quantify apoptosis (expressed in arbitrary units). M, molecular weight markers (range: 100-2000 bp). One representative experiment from a series of three is shown. 

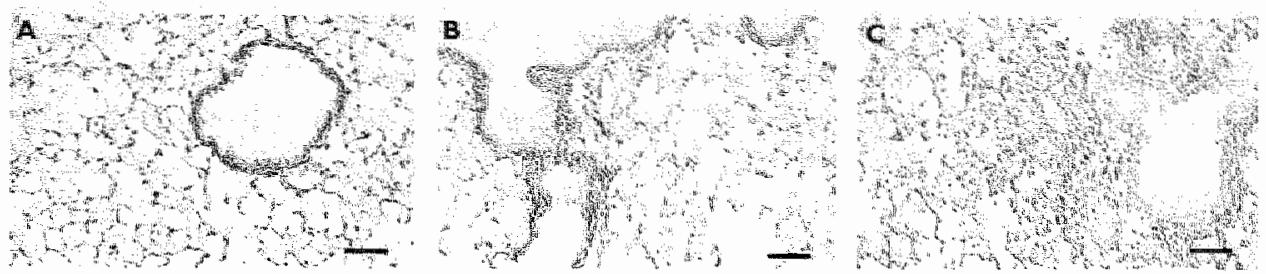

Figure 2. Neutrophil infiltration in lung tissue after IT LPS instillation. Lung tissue of LPS-treated and saline-treated mice was fixed in $10 \%$ formalin, processed according to standard procedure and stained with H\&E. A: Saline-treated, 24 h. B: LPS-treatted, 4 h. C: LPS-treated 24 h. Bar $=60$ fun. Note the accumulation of neutrophils in the alveolar spaces at $24 \mathrm{~h}$ postexposure, which is absent at $4 \mathrm{~h}$ after LPS instillation and in saline-treated controls.

\section{Involvement of neutrophils in IPS-induced early apoptosis in lung tissue}

Several studies have reported that infiltrating neutrophils, recruited to the lungs after IT LPS instillation, are eliminated by apoptosis during the resolution of acute pulmonary inflammation ${ }^{22,23}$. Further, a recent paper suggested that neutrophil presence could induce apoptotic cell death in human bronchial epithelial cells $s^{3}$. Therefore, we examined the role of neutrophils in the observed LPS-induced early apoptosis in the lung by comparing the kinetics of pulmonary apoptosis and pulmonary neutrophil influx after IT LPS instillation. Histologic assessment revealed that local LPS challenge resulted in a time-dependent neutrophil accumulation (Figure 2). Neutrophils were absent at 2 and $4 \mathrm{~h}$ after exposure, but presence of neutrophils in the alveolar spaces was evident from $8 \mathrm{~h}$ after LPS treatment and peaked at $24 \mathrm{~h}$. At $72 \mathrm{~h}$ after exposure, neutrophil accumulation was diminished. In saline-treated and control mice, neither changes in lung histology nor a significant neutrophil influx were observed.

Next, MPO activity in lung homogenates was measured to quantify the relative neutrophil accumulation in the lung. In line with our histologic assessment of neutrophil infiltration, MPO activity was not detected in lung homogenates from LPS-treated mice at 2 and $4 \mathrm{~h}$ after exposure, but MPO activity increased to 17,44 , and 26 units at 8,24 , and $72 \mathrm{~h}$ after LPS instillation, respectively (Figure 3 ).

Figure 3. Quantification of pulmonary neutrophil infiltration after IT IPS instillation. Mice received 5 ug of LLS intratracheally and were killed 2, 4, 8, 24 and $72 \mathrm{~h}$ after instillation. Saline-treated mice were killed $24 \mathrm{~h}$ atter instillation. MPO activity was measured in lung homogenates to quantify the amount of infiltrated neutrophils. Data are expressed in arbitrary units mean 1 SEMI. * $P<0.05$ versus salline.

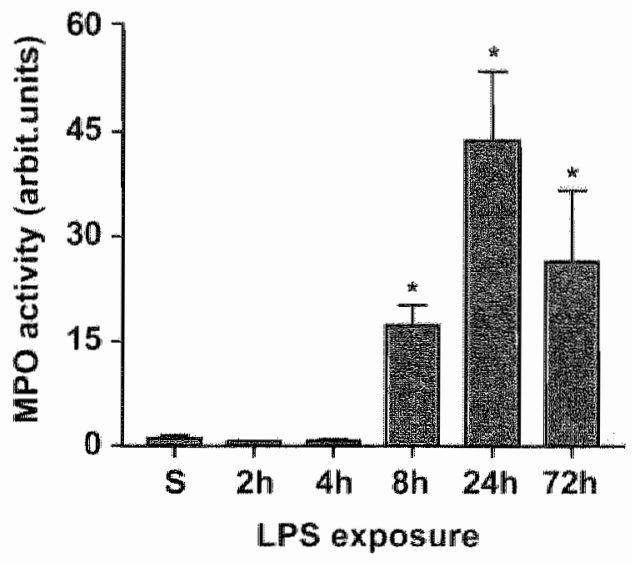


MPO activity was not demonstrated in lung tissue of saline-treated or control mice. Comparison of the kinetics of apoptosis (Figure 1) and neutrophil influx (Figure 3) in the lung revealed that apoptosis was evident from $2 \mathrm{~h}$ after instillation, whereas neutrophil infiltration did not occur until $8 \mathrm{~h}$ after LPS challenge, demonstrating that apoptosis clearly preceded the influx of neutrophils. These data show that neutrophils did not contribute to apoptotic cell death af early time points.
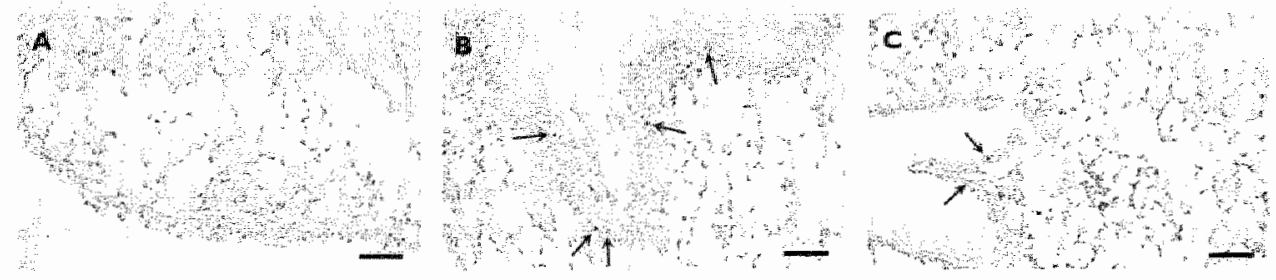

Figure 4. Bronchial epithelial cells undergo early apoptosis in response to local L.PS administration. Lung tissue of L.PS-treated and saline-treated mice was fixed in 10\% formalin, processed according to standard procedure and stained by the TUNEL method. (A) Saline-treated, $4 \mathrm{~h}$. (B) LPS-treated, $4 \mathrm{~h}$. (C) LPS-treated, 24 h. Bar $=60 \mu \mathrm{m}$. Note the brown nuclear staining in bronchial epithelial cells (arrows) at 4 and 24 h after LPS exposure, which is absent in other pulmonary cell types. Infiltrated neutrophils displayed positive staining at $24 \mathrm{~h}$ postexposure.

\section{Apoptotic cell death in bronchial epithelial cells after IT LPS instillation}

Next, we performed TUNEL on lung sections to determine which pulmonary cells undergo apoptosis after IT LPS treatment. As shown in Figure 4, TUNEL demonstrated intense brown nuclear staining in part of the bronchial epithelial cells from $4 \mathrm{~h}$ after LPS exposure, indicating apoptotic cell death. Morphologic examination demonstrated characteristic condensed chromatin in the nuclei of positive-stained bronchial epithelial cells, confirming their apoptotic state. In contrast, other pulmonary cells, e.g., alveolar type II and I cells, smooth-muscle cells, endothelial cells, and alveolar macrophages, did not display positive staining at any time point after local LPS challenge. From $24 \mathrm{~h}$ after exposure onward, mainly infiltrated neutrophils displayed positive staining and onlly few bronchial epithelial cells did so, whereas at $72 \mathrm{~h}$ after exposure positive nuclear staining was demonstrated only in infiltrated neutrophils. These results demonstrated early apoptosis in bronchial epithelial cells after IT LPS exposure followed by apoptosis in infiltrated neutrophils at later time points.

\section{LPS-induced early apoptosis in lung tissue is not mediated by TNF- $\alpha$}

Because the proinflammatory cytokine TNF- $\alpha$ is suggested to be the primary mediator in endothelial apoptotic cell death after systemic administration of LPS, we investigated the role of TNF- $\alpha$ in the observed early apoptosis after IT LPS challenge. To confirm the presence of TNF- $\alpha$ in lungs after local LPS administration, we examined TNF- $\alpha$ protein production by specific ELISA. As shown in Table 1, IT LPS instillation resulted in elevated levels of TNF- $\alpha$ protein in the BALF, peaking at $4 \mathrm{~h}$. TNF- $\alpha$ protein was not detectable in plasma, indicating 
local production of TNF- $\alpha$ in the lung. To further establish that TNF- $\alpha$ was lungderived, expression of messenger RNA (mRNA) for TNF- $\alpha$ was assessed by RTPCR. Figure 5 shows enlanced pulmonary TNF- $\alpha$ mRNA expression at $2 \mathrm{~h}$ after LPS challenge, as compared with saline-treated mice.

Table 1. TNF-a levels in BALF and plasma after IT LPS challenge*

\begin{tabular}{lccccc}
\hline & & & LPS & \\
\cline { 2 - 5 } & Saline & $4 h$ & $24 h$ & 72 \\
\hline BALF & $<50^{\prime}$ & $650 \pm 266^{t}$ & $126 \pm 72^{7}$ & $<50$ \\
Plasma & $<50$ & $<50$ & $<50$ & $<50$
\end{tabular}

* Mice $(n=6)$ received $5, \mu \mathrm{g}$ of IT LPS and were killed 4,24 , and 72 h after instilation. Control mice received $\Pi T$ salime and were killed $24 \mathrm{~h}$ after instillation. TNF $\alpha$ was measured in BALF and plama by specific ELISA for murine TNF- $\alpha$.

TNF-a is expressed in pg/mi. Data are expressed as means \pm SEM.

$P<0.05$ versus saline.

Figure 5. Transcription of TNF- $\alpha$ and B-actin in murine lung tissue as determined by RT-PCR. Mice received $5 \mu \mathrm{g}$ of LPS or saline (S) $I T$ and were sacrificed $2 \mathrm{~h}$ after instillation. Total RNA was isolated from lung tissue and analysed for TNF- $\alpha$ and B-actin mRNA expression using RT-PCR. Equali intensity of 18 -actin mRNA bands confirmed equal loading of CDNA in RT-PCR. One representative experiment from a series of three is shown.

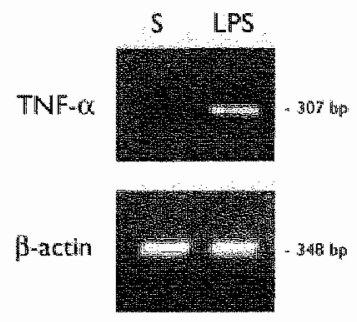

Next, mice were instilled intratracheally with a high dose of murine rTNF- $\alpha$ ( 5 $\mu \mathrm{g}$ ) to investigate the properties of TNF- $\alpha$ to induce apoptosis in lungs. Because LPS-induced TNF- $\alpha$ production was evident from $2 \mathrm{~h}$ after instillation, mice were killed at $2 \mathrm{~h}$ after exposure, and the extent of DNA laddering in the lung was determined by LM-PCR. Figure 6A shows that local TNF- $\alpha$ instillation did not induce DNA laddering (intensity: 360-bp band 0.2 U [TNF- $\alpha$ ] versus 7.5 U [LPS]). To confirm these results, TNF/LT- $\alpha$ double-knockout mice $(-/)$ and wild-type $(+/+)$ control mice were used. Mice received LPS or saline intratracheally, and were killed at $4 \mathrm{~h}$ after instillation. As shown in Figure 6B, basic levels of DNA fragmentation ladders differed between TNF/LT- $\alpha \%$ and $+/+$ mice (intensity: $360-$ bp band $1.0 \cup[S-/-]$ and $0.1 \cup[S+/+])$. In spite of this difference, local LPS exposure resulted in increased DNA laddering in both TNF/LT- $\alpha-$ and $+1+$ mice (intensity: 360-bp band $5.7 \mathrm{U}$ [LPS $-/$ ] and $2.1 \mathrm{U}$ [LPS $+/+$ ]) compared with saline-treated controls, thereby demonstrating that in the absence of TNF- $\alpha$, DNA laddering was induced by IT LPS instillation. Together, these data clearly demonstrate that TNF- $\alpha$ is not the primary mediator in LPS-induced early apoptotic cell death in the lung. 


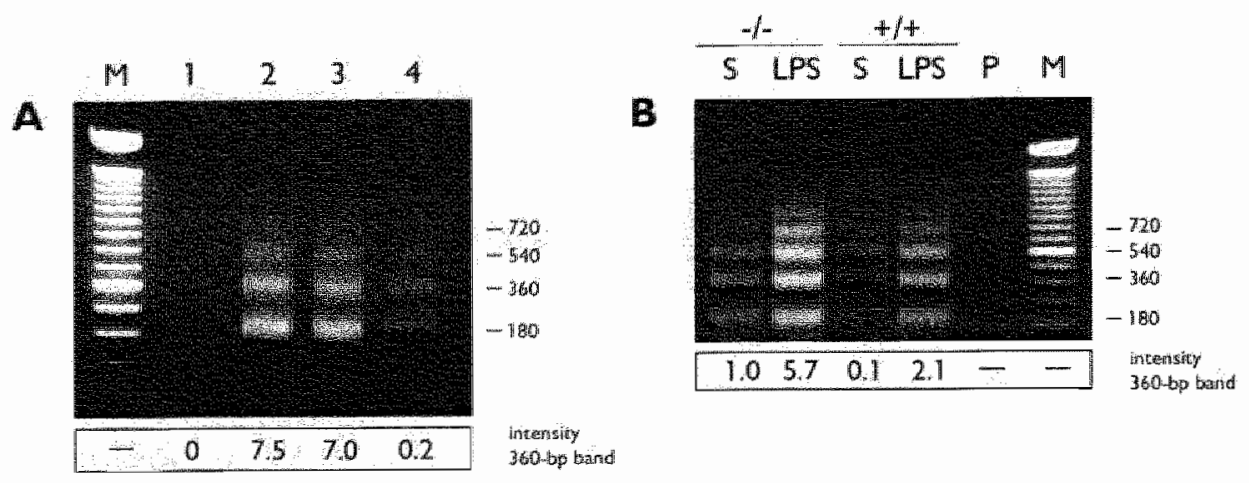

Figure 6. TNF-or is not involwed in L.PS-induced early apoptosis in lung tissue. (A) TNF-a neutralisation or IT TNF-a instillation. Swiss mice received saline (lane 1), $5 \mu \mathrm{g}$ of LPS IT (Jane 2), or mice were pretreatment with an anti-TNF- $\alpha$ antibody (TN3, 1 mg/mouse) $2 \mathrm{~h}$ prior to LPS instillation (lame 3). Mice were sacrificed $4 \mathrm{~h}$ after IT treatment. An additional set of mice received $5 \mu \mathrm{g}$ of murine TNF- $\alpha$ UT (lane 4) and was sacrificed after $2 \mathrm{~h}$. DNA fragmentation in lung tissue was detected by LM-PCR, and intensity of 360-bp band was analysed cexpressed in arbitrary units). $M$, molecular weight markers (range: 100-2000 bop). Note that anti-TNF-ch administration did not reduce DNA laddering induced by IT LPS, whereas IT TNF- $\alpha$ instillation did not result in DNA ladderng. (B) LPS-induced early apoptosis in lung tissue of TNF/LT-a knockout mice. TNF/LT $\alpha$ knockout $(-/)$ and wildtype $(H / H)$ mice received IT saline (S) or $5 \mu \mathrm{g}$ of LPS (LPS), and were sacrificed 4 h pastexposure. M, molecular weight markers. Note that IT LPS exposure in both TNF/T- $\alpha-1-$ and $+1+$ resulted in increased DNA laddering. One representative experiment from a series of three is shown.

\section{DISCUSSION}

LPS is ubiquitously present as a contaminant on airborne particles, including air pollution, organic dusts ${ }^{5}$, and cigarette smoke ${ }^{6}$. Local exposure to LPS is known to be associated with pulmonary cytokine production resulting in infiltration of neutrophils and pulmonary injury. However, little is known about the direct effects of LPS in pulmonary injury, such as apoptotic cell death. In this study, apoptosis in lung tissue after local (IT) exposure to LPS of $5 \mu \mathrm{g} /$ mouse was investigated. This amount of LPS was considered relevant, taking into account that smoking of one cigarette delivers approximately $0.2 \mu \mathrm{g}$ LPS to the lung ${ }^{6}$ and the reported 2 to $3 \log$ less sensitivity of mice to LPS compared with humans ${ }^{24,25}$. Moreover, occupational exposture to (organic dust containing) LPS is known to deliver an even higher LPS dose (30 to $60 \mu \mathrm{g}$ ) to the lung over an 8-h work shift ${ }^{26}$. To identify apoptosis in lung tissue, we used LM-PCR on genomic DNA, a very sensitive technique that enables detection of apoptosis in small percentages of cells $^{27}$. Interestingly, our results show that IT LPS instillation resulted in induction of DNA fragmentation ladders in lung tissue, which was already evident $2 \mathrm{~h}$ after LPS treatment, thereby indicating that IT IPS instillation induces apoptosis in the lung at early time points. Histologic analysis by TUNEL using the sensitive digoxygenin (DIG)-anti-DIG labeling system, which reduces the chance of detecting secondary necrotic cells ${ }^{22}$, demonstrated nuclear staining in bronchial 
epithelial cells from $4 \mathrm{~h}$ after exposure. Additional morphological examination demonstrated characteristic condensed chromatin in the nuclei of positive-stained bronchial epithelial cells, thereby confirming their apopitotic state in response to it LPS instillation.

Neutrophils play a prominent role in the host defense against pathogens, but are also considered to be responsible for pulmonary injury by the release of toxic contents, such as proteinases and oxygen radicals. Disruption of bronchial epithelial cell interactions with neighbor cells or extracellular matrix is known to emthance apoptosis ${ }^{10.23}$, which could be one of the mechanisms for neutrophils to induce pulmonary injury. Indeed, a recent study showed that neutrophil presence induced apoptotic cell death in bronchial epithelial cells in vitro ${ }^{*}$. Our finding that apoptosis in the LPS-challenged lung clearly preceded pulmonary neutrophil infiltration excludes the possibility that neutrophils are involved in bronchial epithelial cell apoptosis at early time points. These observations are in line with a previous study, demonstrating that LPS-induced endothelial cell apoptosis in vivo also occurred in absence of an inflammatory response ${ }^{2}$. Interestingly, TUNEL. revealed that infiltrated neutrophils displayed positive staining from $24 \mathrm{~h}$ after LPS exposure, thereby demonstrating that apoptotic cell death in infiltrating neutrophils contributes to increased DNA laddering seen in lungs at later time points after exposure. In line with our observations in mice, infiltrated neutrophils are reported to be eliminated from sites of acute inflammation by apoptosis in rat models of acute pulmonary inflammation, induced by ozone ${ }^{22}$ or IT LPS ${ }^{23}$ exposure. In these rats, apoptotic neutrophils become quickly engulfed and degraded by alveolar macrophages, which may explain the quick decrease in DNA laddering in lungs observed in our murine model at $72 \mathrm{~h}$ after LPS exposure.

TNF- $\alpha_{,}$a proinflammatory cytokine with pleiotropic effects, is known to be rapidly produced in the lung during acute pulmonary inflammation after local LPS exposure ${ }^{29,30}$ as was also demonstrated at both $\mathrm{mRNA}$ and protein levels in this study. TNF- $\alpha$ is also known to induce apoptosis in various cell types both in vitro and in wivo. Murine models of endotoxic shock have provided abundant evidence that TNF- $\alpha$ acts as the primary mediator in LPS-induced endothelial cell apoptosis in lung ${ }^{3,3}$, with ceramide as the intracellular effector molecule? ${ }^{2}$. In contrast with the role of TNF-a in LPS-induced endothelial cell apoptosis, our findings exclude TNF- $\alpha$ as a primary mediator in bronchial epithelial cell apoptosis induced by IT LPS instillation. We showed that anti-TNF- $\alpha$ treatment did not decrease the extent of DNA laddering in lung tissue at $4 \mathrm{~h}$ after exposure as compared with LPStreated controls, whereas pulmonary neutrophil infiltration was reduced $24 \mathrm{~h}$ after LPS exposure, thereby confirming that biologic activity of TNF- $\alpha$ was inhibited. These results were confirmed by experiments performed in TNF/LT-a doubleknockout mice, which demonstrated that DNA fragmentation ladders in lung tissue increased 4 h after LPS exposure in both TNF/LT- $\alpha$ knockout and wild-type mice. Moreover, exposure of mice to a high dose of murine rTNF $\alpha$ intratracheally did not increase DNA laddering in lung tissue. Mallampalli and associates ${ }^{3}$ recently reported that IT TNF- $\alpha$ instillation in rats did not increase apoptosis in 
another type of puimonary epithelial cells (alveolar type II cells) at 4 to $24 \mathrm{~h}$ after exposure. These studies suggest that TNF- $\alpha$ is not essential for epithelial cell apoptosis in the lung.

The present observations suggest a direct role for LPS in bronchial epithelial cell apoptosis. To our knowledge, only few studies have investigated the mechanisms underlying LPS-induced apoptosis in vitro and in vivo. HaimovitzFriedman and coworkers ${ }^{2}$ demonstrated that endothelial cell apoptosis induced by systemic LPS exposure is mediated by sequentially TNF- $\alpha$ and ceramide, which is known to act as a second messenger in pleiotropic cellular functions, including proliferation, differentiation, and apoptosis ${ }^{32}$. A possible mechanism for LPSmediated apoptosis in epithelial cells may involve Toll-like receptor (TLR)-4, which has been identified as transmembrane coreceptor in the LPS binding protein (LBP)/CD14-dependent LPS signaling across the cell membrane ${ }^{33}$. Recently, upregulation of TLR-4 mRNA was demonstrated in heart and lung in response to LPS administration ${ }^{34}$. The observation that LPS-induced DNA laddering in endothelial cells was inhibited by addition of an anti-CD14 antibody " supports the involvement of the LBP/CD14/TLR-4 pathway in LPS-mediated apoptotic cell death. Another mechanism by which LPS could trigger apoptosis may be via directly mimicking the second messenger function of ceramide in apoptotic cell death. Lipid $A$ is known to have strong structural similarities with ceramide ${ }^{35}$. In addition, in vitro studies also suggested functional similarities between LPS and ceramide. Joseph and colleagues ${ }^{35}$ demonstrated that lipid A and native LPS directly stimulated ceramide-activated protein kinase (CAPK) activity, a direct intracellular target for ceramide in the process of apoptosis, in human leukemia (HL-60) cells and isolated human neutrophils without generating ceramide. This CAPK activity was markedly enhanced by LBP and required CD14. The observation that LPS can be transferred into phospholipid bilayers by CD14 and $\mathrm{LBP}^{36}$ supports the idea that LPS can directly interact with ceramide-responsive enzymes in the plasma membrane. Whether CD14, TLRs, and ceramide are involved in bronchial epithelial cell apoptosis observed after IT LPS exposure needs to be further elucidated.

The respiratory system is challenged continuously by LPS via inhaled air containing airborne particles and pathogens. In this study we have demonstrated that IT exposure of a relevant dose of LPS induces a mild transient acute inflammation preceded by apoptosis in part of the bronchial epithelial cells throughout the bronchial tree. Whether this early induced apoptotic cell death contributes either to tissue damage, due to disturbance of the main barrier between the environment and the respiratory system, or to innate immunity is not yet understood. However, apoptosis is increasingly being identified as a protective response by the host to pathogens, with the suicide of individual cells enhancing the survival of the multicellular organism as a whole ${ }^{37}$. We consider the demonstrated apoptosis important, because clearance of harmed bronchial epithelial cells by the process of apoptosis would prevent disruption of the epithelial layer (as necrosis would do), thereby preventing the spread of pathogens. Further research needs to be performed to elucidate the role of LPS- 
mediated bronchial epithelial cell apoptosis in awway injury.

\section{ACKNOWLEDGEMENTS}

We thank Dr. Esther Koerts-de Lang for her expent technical assistance. We thank Dr. H.P. Eugster and Prof. P. Brouckaert for the TNF/LT mice, and for the possibility to perform these experiments at the Laboratory of Molecular Biology, University of Gent (Gent, Belgium). This work was supported by Glaxo Wellcome, The Netherlands.

\section{REFERENCES}

1. Bohlinger I, Leist $M$, Gantner $F$, Angermuller $S$, Tiegs $G$, and Wendel $A$. DNA fragimentation in mouse organs during endotoxic shock. Am I Pathol 1996;149:1381-1393.

2. Haimovitz Friedman $A$, Cordon Cardo $C$, Bayoumy $S$, Garzotto $M_{*}$ Mcloughlin $M$, Gallily $R_{*}$ Edwards CK, 3rd, Schuchman EH, Fuks $Z$, and Kolesnick R. Lipopolysaccharide induces disseminated endothelial apoptosis requiring ceramide generation. / Exp Med 1997;186:183\%. 1841.

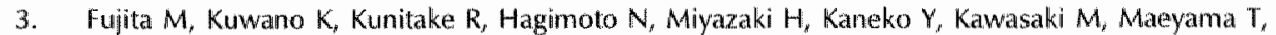
and Hara N. Endothelial cell apoptosis in lipopolysaccharide-induced lung injury in mice. Int Arch Allergy Immunol 1998;117:202-208.

4. Kline $\mathrm{JN}$, Cowden $\mathrm{ID}$, Hunninghake $\mathrm{GW}$, Schutte $\mathrm{BC}$, Watt JL, wohliford Lenane $\mathrm{CL}$, Powers $1 . \mathrm{S}_{\text {, }}$ Jones MP, and Schwartz DA. Variable airway responsiveness to inhaled lipopolysaccharide. Am I Respir Crit Care Med 1999;160:297-303.

5. Rylander $R_{t}$ Haglind $P$, and Lundholm M. Endotoxin in cotton dust and respiratory function decrement among colton workers in an experimental cardroom. Am Rew Respir Dis $1985 ; 131: 209-213$.

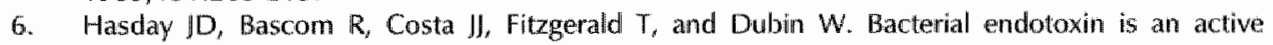
component of cigarette smoke. Chest 1999;115:829-835.

7. Wagner $\| G_{y}$ and Roth RA. Neutrophil migration during endotoxemia. / Leukoc Biol 1999;66:1024.

8. MCDonald RJ, and Usachencko f. Neutrophils injure bronchial epithelium after ozone exposure. Inflammation 1999;23:63-73.

9. Bingisser $R_{t}$ Stey $C$, Weller $M$, Groscurth $P_{*}$ Russi $E$, and Frei $K$. Apoptosis in human alveolar macrophages is induced by endotoxin and is modulated by cytokines. Am / Respir Cell Mol Biol $1996 ; 15: 64-70$.

10. Hoyt DG, Mannix RJ, Rusnak IM, Pitt BR, and Lazo IS. Collagen is a survival fartor against LPSinduced apoptosis in cultured sheep pulmonary attery endothelial cells. Am J Physiol $1995 ; 269: 117 \|-177$.

11. Frey $E A$, and Finlay $B B$. Lipopolysaccharide induces apoptosis in a bovine endothelial cell line via a soluble CD14 dependent pathway. Microb Pathog 1998;24:101-109.

12. Eugster HP, Muller $M$, Karrer $U$, Car BD, Schnyder $B$, Eng VM, Woerly $G$, Le Hir $M$, di Padova $F$,

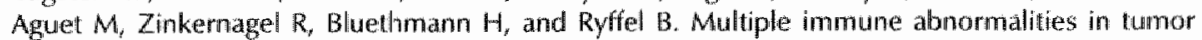
necrosis factor and lymphotoxin-alpha double-deficient mice. Int Immunol 1996;8:23-36.

13. Starcher B, and Williams I. A method for intratracheall instillation of endotoxin into the lungs of mice. Lab Anim 1989;23:234-240.

14. Walley $K_{r}$ MCDonald TE, Higashimoto $Y$, and Hayashi S. Modulation of proinflammatory cytokines by nitric oxide in murine acute lung injury. Am / Respir Crit Care Med 1999;160:698704.

15. Shellito JE, Kolls JK, and Summer WR. Regulation of nitric oxide release by macrophages after intratracheal lipopolysaccharide. Am / Respir Cell Mol Biol 1995;13:45-53. 
16. Berridmans MH, Couma DI, Creve WW, and Burman Wh Effect of antitumour necrosis factor treatment on circulating tumour necrosis factor levels and mortality after surgery in jaundiced mice. Br f Surg 1993,80:1055*1058.

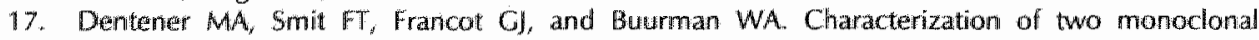
antibodies directed against bactericidalpermeability-incteasing protein. I Infect Dis $1994 ; 170: 1483-1489$.

10. Cavrieli $Y$, Sherman $Y$, and Ben Sasson SA Udentification of programmed cell death in situ via specific labeling of nuclear DNA fragmentation. / Cell Bul 1992,119:493-501.

19. Kubbler Wh, Abels $\mathrm{C}_{\text {i }}$ Schuerer $\mathrm{L}$; and Coetz $\mathrm{AE}$. Measurement of neutrophill content in brain and lung tissue by a modified myeloperoxidase assay, Mn / Microcirc Clin Exp 1996,16:89.97.

20. Daemen MA, wan de Ven MW, Hememan E, and Bumman WA. Hnwolvement of cndogenous interteukin-10 and tumor necrosis factor-alpha in renal ischemia-reperfusion injury. Transplantation 1999;67:792-800.

21. Dentener MA, Greve NW, Maessen JG, and Butrman WA. Role of tumour necrosis factor in the enhaniced sensitivity of mice 10 endotoxin after exposure to lead. Immunopharmacol Imrnunotoxicol 1989, $11: 321-334$.

22. Ishii $Y$, Hashimoto $K$, Nomura $A$, Sakamoto $T$, Vchida $Y$, Ohtsuka M, Hasegawa $S$, and Sagai $M$. Elimination of neutrophils by apoptosis during the resolution of acute pulmonary inflammation in rats. Lurg 1998; $176: 89-98$.

23. Cox C, Crossley J, and Xing Z. Macrophage engulfment of apoptotic neutrophuls contributes to the resolution of acute pulmonary inflammation in vivo. An / Respir Coll Mol Biol 1995, 12:232. 237,

24. Urbaschek B, and Utbaschek R. The intlammatory response to endotoxins. Bibl Anat 1979;17:74104.

25. Berczi I, Bertok L, and Berezmai T. Comparative studies on the toxicity of Escherichia coli lipopolysaccharide endotoxin in various anumal species. Car J Microbiol 1966;12:1070-1071.

26. Rask Andersen $A$, Malmberg $P$, and Lundhollm $M$. Endotoxin levels in farming: absence of symptoms despite high exposure levels. $\mathrm{Br}$ / Ind Med 1989;46:412-416.

27. Staley $K$, Blaschke $M$, and Chun 1. Apoptotic DNA fragmentation is detected by a semiquantitative ligation-mediated PCR of blunt DNA ends. Cell Death Diff 1997;4:66-75.

28. Aoshiba K. Rennard SI, and Spurzem JR. Cell-matrix and cell-cell interactions modulate apoptosis of bronchial epithelial cells. Am J Physiol 1997;272:128-37.

29. Arreto $C-D$, Dumarey $C$, Nahori $M-A$, and Vargaftig BB. The L.PS-induced neutrophill recruitment into nat air pouches is mediated by TNF: likely macrophage origin. Med Irffarn 1997;6:335-343.

30. Johnston $\mathrm{Cl}$. Finkelstein $\mathrm{IN}$, Gelein $\mathrm{R}$, and Oberdorster G. Pulmonary cytokine and chemokine mRNA levels after inhalation of lipopolysaccharide in C57BL/6 mice. Toxicol Sci 1998;46:300307.

31. Mallampalli RK, Peterson Ej, Carter AB, Salome RG, Mathur SN, and Koretzy CA. TNF-alpha increases ceramide without inducing apoptosis in alveolar type ll epithellal ceils. Am J Physhol $1999 ; 276: 481-490$

32. Puslakareva M, Obeid LM, and Hannun YA. Ceramide: an endogenous regulator of apoptosis and growth suppression. Immunol Today 1995;16:294.297.

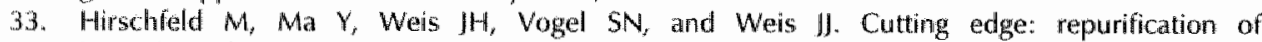
lipopolysacdnaride eliminates signaling through both human and murine toll like receptor 2 . I Imomunol $2000 ; 165: 618-622$.

34. Matsumura T, Ito A, Takii T. Hayashi H, and Onozaki $K$. Endotoxin and cytokine regullation of tolllike receptor (TLR) 2 and TLR4 gene expression in murine liver and hepatocytes. I Interferon Cylokine Res 2000;20:915-921.

35. Joseph CK, Wright SD, Bornmann WG, Randolph T, Kumar ER, Bitman $R$, Liu J, and Kolesnick RN. Bacterial lipopolysaccharide has structural similarity to ceramide and stimulates ceramide. activated protein kinase in myeloid cells. B Biol Chem $1994,269: 17606-17610$.

36. Wurtel $M M$, and Wright SD. Lipopolysaccharide-binding protein and soluble CD14 transfer lipopolysaccharide to phosphotipid bilayers: preferential interaction with particular classes of lipial. J limmunol 1997; 158:3925-3934.

37. Williams GT. Programmed cell death: a fundamental protective response to pathogens. Trends Microbiol $1994: 2: 463-464$. 


\title{
CHAPTER 8
}

\section{Rapid expression of acute-phase reactants in lung after local LPS exposure in mice}

\author{
Juanita H.J. Vernooy ${ }^{7}$, Niki L. Reynaert ${ }^{7}$, Tim G.A.M. Wolfs' ${ }^{2}$, Bart de Vries ${ }^{2}$, \\ Mieke A. Dentener ${ }^{1}$, Wim A. Buurman ${ }^{2}$, and Emiel F.M. Wouters ${ }^{1}$ \\ Departments of ${ }^{1}$ Respiratory Medicine and ${ }^{2}$ General Surgery, University \\ Hospital Maastricht, Maastricht, The Netherlands
}

\section{Submitted}

\section{ABSTRACT}

The respiratory system is continuously exposed to lipopolysaccharide (LPS) due to inhalation of airborne LPS present as contaminant on cigarette smoke, air pollution, organic dusts, house dust. Expression of acute-phase reactants (APRs) at the site of L.PS exposure may enhance the early innate immune response to injury and infection. The present study aims to investigate pulmonary and hepatic expression of four major murine APRs in a murine model of acute lung inflammation induced by intratracheal (IT) LPS exposure. We report that local LPS exposure resulted in increased pulmonary expression of mRNA for $\alpha_{1}$-antitrypsin $\left(\alpha_{1}\right.$-AT), $\alpha_{1}$-acid glycoprotein (AGP), and LPSbinding protein (LBP) at $4 \mathrm{~h}$, which was also present at $24 \mathrm{~h}$ and $72 \mathrm{~h}$ after LPS exposure. Little or no expression of APRs was detected in lung tissue of control mice. Although pulmonary expression of SAP MRNA was not induced by LPS exposure, systemic levels of SAP were elevated from $24 \mathrm{~h}$ post-exposure. In adidition, plasma AGP and LBP were elevated, whereas plasma $\alpha_{1}-A T$ remained unchanged. Systemic elevation of APRs was found to be associated with increased hepatic expression of mRNA for SAP, AGP, and LBP from $24 \mathrm{~h}$ after local LPS exposure. Furthermore, plasma IL-6 levels were increased rapidly after local LPS exposure, suggesting that IL-6 acts as mediator between the pulmonary and hepatic system. In conclusion, local LPS exposure induces rapid expression of APRs in the lung, which proceeds systemic elevation of APRs associated with hepatic APRs expression. 


\section{INTRODUCTION}

Endotoxin and its purified derivative lipopolysaccharide (LPS) are major proinflammatory constituents of the outer cell wall of Gram-negative bacteria, and ubiquitously present as contaminant on airborne particles, including air pollution', organic dusts ${ }^{2,3}$, house dust ${ }^{4}$, and cigarette smoke. ${ }^{5}$. Due to inhalation of airborne LPS as well as aspiration of bacteria from commensal flora in the oral and nasal cavities, the respiratory system is continuously exposed to LPS.

In normal subjects, inhalation of endotoxin induces dose-related clinical symptoms, such as fever and fatigue, changes in lung function, and activation of the innate immune system ${ }^{6}$. There is, however, a considerable inter-individual variability in the sensitivity to endotoxin by inhalation, as subjects with asthma ${ }^{7}$ or chronic bronchitis ${ }^{8}$ develop airflow obstruction at a lower endotoxin dose.

Extensive studies on LPS-induced inflammation have demonstrated that LPS activates cells via a LPS binding protein (LBP)/CD14/Toll-like receptor (TLR)-4/MD-2 dependent pathway (reviewed by Alexander and Rietschel ${ }^{9}$ ). In the lung, pulmonary LPS exposure is known to result in an acute inflammatory response, which is characterized by pulmonary expression of pro-inflammatory mediators and rapid but transient neutrophil infiltration into the interstitium, alveoli, and airways ${ }^{10}$. In line herewith, bronchoalveolar neutrophil influx as well as high concentrations of interleukin (IL)-8, IL-6, IL-1 3 , and tumor necrosis factor-alpha (TNF- $\alpha$ ) have been measured in bronchoalveolar lavage fluid and induced sputum after inhalation of endotoxin by healthy subjects ${ }^{6,11,12}$.

In addition to local inflammation, inhalation of endotoxin in normal subjects was found to be associated with rapid blood leukocytosils and neutrophilia. Furthermore, a subsequent rise in blood concentrations of two acute-phase reactants (APRs), e.g. Creactive protein (CRP) and $L B P$, was noticed at $24 \mathrm{~h}-48 \mathrm{~h}$ postexposure ${ }^{6,13,14}$. APRs play an important role in innate host defense and reduction of acute inflammatory reactions. For example, LBP and serum amyloid $\mathrm{P}$ component (SAP, functional homologue of human CRP in mice) share the capacity to bind to LPS and bacteria ${ }^{9,15}$, whereas $\alpha_{1}$-glycoprotein (AGP) and $\alpha_{1}$-antitrypsin ( $\alpha_{1}$-AT) have strong antiinflammatory properties ${ }^{16-16}$. In addition, $\alpha_{1}$-AT inhibits neutrophil elastase, hereby providing the lung protection from proteolytic digestion that may eventually result in loss of lung recoil and emphysema ${ }^{19}$. Hepatocytes are considered to be the primary producers of circulating APRs, and regulation of the hepatic acute-phase response is largely mediated by the acute-phase cytokines tumor necrosis factor-alpha (TNF- $\alpha$ ), interleukin (IL)-1 and IL-6 acting alone, in combination, or in concert with various steroid hormones ${ }^{20}$.

Recent studies demonstrated that resident lung cells are able to express APRs that may contribute to the innate inmmune response at the site of the initial injury or infection ${ }^{21-23}$. In view of the continuous exposure of the lung to LPS, the current study aims to investigate the contribution of the lung to the acute-phase response as part of innate immune response. To this end, a murine model of acute lung inflammation induced by local (intratracheal, IT) LPS exposure was used, in which the inciting insult is transient and the pulmonary inflammatory response is well defined ${ }^{10}$. We 
composed a panel of major murine APRs, namely ACP, LBP, SAP, and $\alpha_{4}-A T$, which are known to be induced after systemic LPS administration in mice ${ }^{24-26}$. The expression of these APRs was assessed in lung and liver, and APR levels in plasma were measured. In addition, plasma levels of IL-6, TNF- $\alpha$, soluble (s) TNF-receptors were determined to study mediators involved in systemic acute-phase response.

\section{MATERIAL \& METHODS}

\section{Experimental protocol}

Male Swiss mice (8-10 weeks) from Charles River Breeding Laboratories (Heidelberg, FRG) were housed individually in standard laboratory cages and allowed food and water ad libitum throughout the experiments. The studies were carried out under a protocol approved by the Institutional Animal Care Committee of the Maastricht University. Mice ( $n=6$ per group) received a single intratracheal (IT) instillation of 5 $\mu \mathrm{g}$ LPS (Escherichia coli, serotype O55:B5, Sigma, St. Louis, MO) in $50 \mu 10.9 \% \mathrm{NaCl}$ as described in detail previously ${ }^{10}$. LPS-treated mice demonstrated a profound neutrophil influx in the alveolar spaces from $8 \mathrm{~h}$ after instillation of LPS, peaking at 24 h. Control mice received the same volume of LPS-free sterile $0.9 \% \mathrm{NaCl}$ or were not treated, and neither changes in lung histology nor a significant neutrophil influx were observed in these mice. Mice were killed at 4, 8, 24 or $72 \mathrm{~h}$ after instillation, and lungs and liver were prepared for RNA extraction. Blood was collected by heart puncture and kept at $4^{\circ} \mathrm{C}$ in EDTA containing tubes for not more than 1 hour prior to further processing. Plasma samples were stored at $-80^{\circ} \mathrm{C}$ until analyzed.

\section{Determination of plasma AGP and $\alpha_{1}$-AT levels by western blot analysis}

Plasma samples were diluted $1: 1000$ in a buffer containing $60 \mathrm{mM}$ Tris $\mathrm{HCl} \mathrm{pH} \mathrm{6.8,}$ $25 \%$ glycerol, $2 \%$ SDS, $0.01 \%$ bromophenol blue, and $5 \%$ B-mercaptoethanol. After heating for $5 \mathrm{~min}$ at $95^{\circ} \mathrm{C}, 40 \mu \mathrm{l}$ of sample was separated on a $6 \%$ polyacrylamide/SDS gel by electrophoresis. Proteins were transferred to PVDF membranes (Millipore BV, Etten-Leur, The Netherlands), and washed in wash buffer (Tris-buffered Saline (TBS)/0.1\%Tween20). Subsequently, nonspecific binding sites were blocked for $1 \mathrm{~h}$ with TBS/0.1\%Tween 20 containing $1 \%$ BSA and washed. Membranes were incubated for $1 \mathrm{~h}$ with rabbit anti-murine AGP PAb (kindly provided by Dr. P. Heegaard, Danish Veterinary Laboratory, Copenhagen, Denmark) or rabbit anti-murine $\alpha_{1}$-AT pAb (kindly provided by Dr. C. Libert, University of Ghent, Ghent, Belgium) diluted 1:20,000 in incubation buffer (TBS/0.1\%Tween $20 / 0.1 \%$ BSA). After washing, membranes were incubated for $1 \mathrm{~h}$ with peroxidase-labeled goat anti-rabbit IgG (Jackson, West Grove, PA) diluted 1:2,000 in incubation buffer. The membranes were finally developed using enhanced chemoluminescence (Pierce, Rockford IL, USA) and exposed to $X$-ray fillms. The expected size of the band is $40-43 \mathrm{kDa}$ for $\mathrm{AGP}^{16}$, and $57.7 \mathrm{kDa}$ for $\alpha_{1}-\mathrm{AT}^{27}$. 
Table 1. Rr.pCR primers

\begin{tabular}{|c|c|c|c|}
\hline $\begin{array}{l}\text { mRNA of } \\
\text { Interest }\end{array}$ & Sequences & $\begin{array}{l}\text { Annealing } \\
\text { Temperature }\end{array}$ & $\begin{array}{l}\text { Product } \\
\text { Lengih }\end{array}$ \\
\hline \multirow{2}{*}{$a_{3}+A \pi$} & Sense: $5^{\prime}$ - TCC CAT GAG ATC GCT ACA AAC-3' & \multirow{2}{*}{$54^{\circ} \mathrm{C}$} & \multirow{2}{*}{350 bp } \\
\hline & Antisense $5^{\prime}$ TGA VAA TGC TTC TTG GCC TCT-3' & & \\
\hline \multirow{2}{*}{ AGP } & Sense: $5^{\prime}$ - GCG CCT GTC CTA AAC CCT-3r & \multirow{2}{*}{$54{ }^{\circ} \mathrm{C}$} & \multirow{2}{*}{$390 \mathrm{bp}$} \\
\hline & Antisense:-5'-CAA GTCAAA GCC AAG CAT G-3' & & \\
\hline \multirow{2}{*}{ LBP } & Sense: $5^{\prime}$-CGG TGG CTG CTG AAT CTC T-3' & \multirow{2}{*}{$54{ }^{\circ} \mathrm{C}$} & \multirow{2}{*}{$340 \mathrm{bp}$} \\
\hline & Antisense: 5-TGI" TCA AGG CAT GAT CTG ACAA-3" & & \\
\hline \multirow{2}{*}{ SAP } & Sense: $5^{\prime}$-CT CAC CAG CCT TCT TTC AGA-3' & \multirow{2}{*}{$54{ }^{\circ} \mathrm{C}$} & \multirow{2}{*}{$280 \mathrm{bp}$} \\
\hline & Antisense 5'-ACC GAC TGT GAC TIT TGA TTG T-3* & & \\
\hline \multirow{2}{*}{$11-6$} & Sense: $5^{\circ}$-TGG CAAATC GTG GAA ATG AGA-3' & \multirow{2}{*}{$56{ }^{\circ} \mathrm{C}$} & \multirow{2}{*}{$318 \mathrm{bp}$} \\
\hline & Antisense:5'GAG AGC ATT GGA AAT TGG GGT-3' & & \\
\hline \multirow{2}{*}{ TNF } & Sense: $5^{\prime}$ GGC AGG TCT ACT TTG GAG TCA TIG C-3' & \multirow{2}{*}{$63^{\circ} \mathrm{C}$} & \multirow{2}{*}{$307 \mathrm{bp}$} \\
\hline & Antisense: 5-ACA TRC CAG GCT CCA GTC AAT TCG G-3' & & \\
\hline \multirow{2}{*}{ B-actín } & Sense: 5' TAA AAC GCA GCT CAG TAA CAG TCG G-3' & \multirow{2}{*}{$60{ }^{\circ} \mathrm{C}$} & \multirow{2}{*}{$348 \mathrm{bp}$} \\
\hline & Antisense: $5^{\prime}$ - TGC AAT CCT GTG GCA TCC ATC AAA C-3" & & \\
\hline
\end{tabular}

Determination of plasma levels of $I L-6, L B P, S A P, T N F-\alpha$ and sTNF-receptors by ELISA IL-6 concentration in plasma was measured by ELISA. Immunomaxisorp plates (Nunc, Roskilde, Denmark) were coated overnight with monoclonal antibody 20F3 (HM1004) specific for murine IL-6 (kindly provided by Hycult Biotechnology, Uden, The Netherlands). Diluted plasma samples and a standard dilution series with murine IL-6 (a kind gift from Dr. J. van Snick, Ludwig Institute, Brussels, Belgium) were addled to the plate. IL-6 was detected with biotin-conjugated monoclonal antibody $32 \mathrm{C} 11$ (HM1005; Hycult Biotechnology) followed by Streptavidine-HRP (Zymed Laboratories Inc., San Francisco, CA) and 3',5,5'-tetramethylbenzidine (Kirkegaard \& Perry Lab, Gaithersburg, MD) as substrate. The lower detection limit was $20 \mathrm{pg} / \mathrm{ml}$.

Concentrations of LBP, SAP, TNF- $\alpha$ and soluble TNF-R55 and TNF-R75 were determined in plasma using specific enzyme linked immunosorbent assay's (ELISA) as described previously ${ }^{28-31}$. The intra-assay variation was less than $10 \%$. Lower detection limits: LBP: $100 \mathrm{pg} / \mathrm{ml}$; SAP: $500 \mathrm{pg} / \mathrm{ml}$; TNF- $\alpha: 20 \mathrm{pg} / \mathrm{ml}$; sTNF-R75: $50 \mathrm{pg} / \mathrm{ml}$; TNFR55: $5 \mathrm{pg} / \mathrm{ml}$.

\section{Measurement of pulmonary and hepatic APR mRNA content}

Total RNA was isolated from snap frozen lung tissue (right lung) and liver using a commercially available kit (SV Total RNA Isolation System, Promega, Madison, WI). Total RNA concentration and purity was ascertained by ultraviolet spectrophotometric analysis at wavelengths of 260 and $280 \mathrm{~nm}$ as well as electrophoresis on an ethidium bromide-stained $0.8 \%$ agarose gel followed by UV illumination. Five $\mu \mathrm{g}$ of total RNA was subsequently reverse transcribed into CDNA. PCR for SAP, LBP, $\alpha_{1}$-AT, AGP, TNF$\alpha, I L-6$ and $B$-actin was performed in a $25 \mu$ reaction volume containing $100 \mu \mathrm{M}$ of each dNTP, $200 \mathrm{nM}$ sequence-specific primers and 0.5 U Taq DNA polymerase 
(Perkin Elmer/Cetus) during 23-40 cycles under the following conditions: $95^{\circ} \mathrm{C} 30^{\text {it, }}$, annealing temperature (AT) $45^{\prime \prime}, 72^{\circ} \mathrm{C} 30^{\prime \prime}$. PCR primers used in RT-PCR for $\alpha_{1}$ AT, AGP, SAP, TNF- $\alpha$, and $B$-actin were designed as previously described ${ }^{29}$. PCR primers for IL-6 and LBP were developed for this study (Table 1). A mock PCR (without CDNA) was includied to exclude contamination. CDNA samples were standardized based on the content of B-actin CDNA as housekeeping gene, which was evaluated by performance of a B-actin PCR on multiple dilutions of each CDNA sample. After separation on a $1.2 \%$ agarose gel, band proportions were estimated by measuring the intensity of ethidium bromide fluorescence with a CCD camera and Imagemaster VDS software (Pharmacia).

\section{Statistical analysis}

Data are expressed as mean \pm SEM. Statistical analysis was performed by means of Mann-Whitney U test (Statistical Package for the Social Sciences, version 10.0.7 for Windows, SPSS Inc., Chicago, IL). A p-value $<0.05$ denotes the presence of a significant statistical difference.

\section{RESULTS}

Intratracheal LPS exposure results in increased expression of $\alpha_{1}-A T, A G P$ and $L B P$ in lung

Recent studies demonstrated that respiratory epithelial cells and alveolar macrophages are capable of expressing APRs upon stimulation ${ }^{21,22,32}$. In this view, we examined pulmonary mRNA expression of SAP, LBP, AGP, and $\alpha_{1}$-AT after local LPS exposure in vivo using RT-PCR. As shown in Figure 1, no constitutive expression for APRs was found in lung tissue of control mice. However, mRNA levels of LBP, AGP, and $\alpha_{1}$-AT were clearly demonstrated from $4 \mathrm{~h}$ after LPS treatment onwards. Expression of LBP and $\alpha_{1}$-AT peaked at $24 \mathrm{~h}$, and then diminished at $72 \mathrm{~h}$ postexposure, whereas AGP expression levels peaked at $24 \mathrm{~h}-72 \mathrm{~h}$. In contrast, mRNA for SAP was not detected in lung tissues upon IT treatment with LPS.

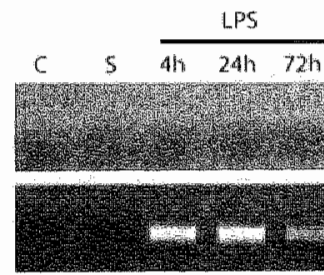

$\$ \mathrm{AP}^{3}$

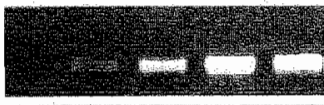

LBP

Figure 1. Transcription of SAP, LBP, ACP, and $\alpha_{y}$,AT in lung as detemined by RT-PCR. Total RNA was isolated from lung tissue of age-matched control mice $[C]$, saline treated mice 151, and LPS-challenged mice killed at 4h, 24h or $72 \mathrm{~h}$. Messenger RNA expression levels of SAP $\$ 280$ bp). LBP $(340$ bp), AGP ( 390 bp), a, AT (350 bp), and B-actin ( 348 bp) were analyzed using RT.PCR $(n=3$ per group). Equal internsity of $B$ actin MRNA bands confrmed equal loading of CDNA in RT. PCR. One representative experiment from a series of the ree is

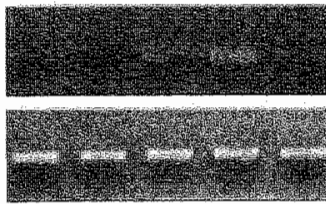

AGP $\alpha_{1} \cdot A \mathrm{~T}$ shown. 


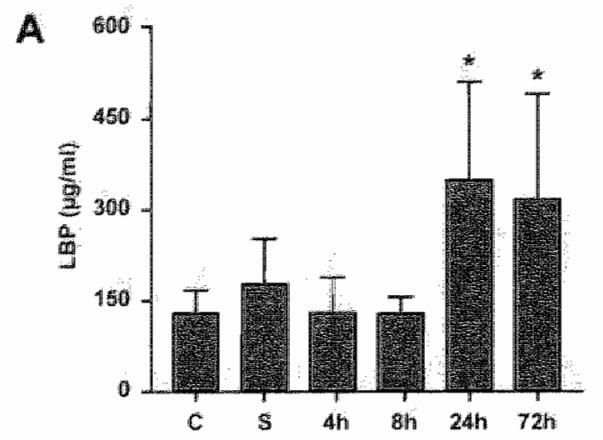

C

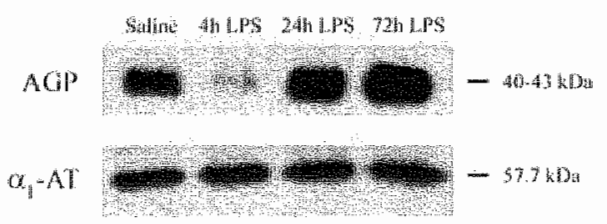

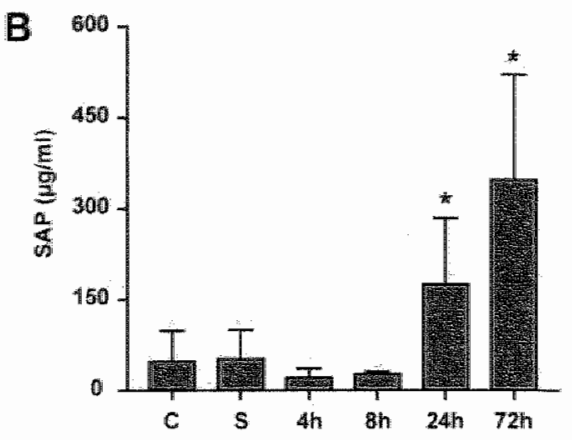

Figure 2. Analysis of $L B P, S A P, A C P$, and $a_{1}$-AT levels in plasma after IT LPS instillation. Mice received $5 \mathrm{~kg}$ of LPS IT and were sacrificed $4,8,24$ and 72 hours after instillation. Saline-treated mice were killed 24 hours after instillation. Plasma levels of (A) $L B P$ and (B) SAP were measured by specific sandwich ELISA ( $\mathrm{n}=6$ per group). Data are expressed in $\mu \mathrm{g} / \mathrm{ml}$ (mean \pm SEMT). Significant increases in mean plasma levels compared with control are indicated by * $(P<0,05)$. Plasma levels of $(C)$ AGP and $\alpha_{1}$-AT were determined by western blot analysis $(n=3$ per group). One representative experiment from at series of three is shown.

Intratracheal LPS exposure results in elevated plasma levels of SAP, LBP, and AGP To address whether pulmonary LPS exposure had also extrapulmonary effects, plasma levels of AGP, SAP, LBP, and $\alpha_{1}$-AT were assessed by ELISA or western blot analysis. As shown in Figure 2A, local LPS administration induced a 2.5-fold elevation of circulating LBP levels at $24 \mathrm{~h}$ and $72 \mathrm{~h}$ post-exposure, whereas LBP levels were not raised in saline-treated mice. Similar to LBP, plasma levels of SAP and AGP increased significantly following $24 \mathrm{~h}$ after LPS instillation, and even further increased at $72 \mathrm{~h}$ (Figure $2 \mathrm{~B}$ and $2 \mathrm{C}$ ). In contrast, we did not observe any apparent raise in plasma $\alpha_{1}$ AT levels after local LPS exposure (Figure 2C). Taken together, these data clearly demonstrate that LPS exposure in the pulmonary compartment results in a systemic acute-phase response, characterized by increased plasma levels of SAP, LBP, and AGP.

\section{Hepatic expression of major APR genes after IT LPS exposure}

The liver is considered to be the major organ in the systemic acute-phase response. To elucidate the source of the elevated levels of APRs after local LPS exposure, we examined hepatic mRNA expression of SAP, LBP, AGP, and $\alpha_{1}$-AT using RT-PCR and compared APR expression and kinetics in lung and liver. As shown in Figure 3, constitutive expression of all transcripts (of the expected size according to the murine CDNA sequence) was detected in the liver tissues. Hepatic mRNA levels of SAP, LBP, and ACP were clearly enhanced at $24 \mathrm{~h}$ and $72 \mathrm{~h}$ after pulmonary LPS treatment as compared to sal ine-treated or untreated controls. In addition, AGP mRNA expression levelis showed a slight, but clear, increase at $4 \mathrm{~h}$ after exposure. In contrast, 
constitutive mRNA levels for $\alpha_{1}$-AT were not upregulated after local LPS exposure.

Comparison of APR expression in the lung (Figure 1) and the liver (Figure 3) revealed that APRs expression patterns were different between lung and liver. Constitutive expression of all APRs examined was demonstrated in liver but not in lung of control mice. Local LPS exposure resulted in increased expression of AGP and LBP in both liver and lung, whereas MRNA for SAP was only detected in the liver. In addition, upregulation of $\alpha_{1}$-AT expression only occurred in the lung. Moreover, we found differences in kinetics of APR expression between liver and lung. Pulmonary LBP expression was evident as soon as $4 \mathrm{~h}$ after LPS exposure, whereas thepatic expression of LBP did not occur until $24 \mathrm{~h}$ after LPS challenge. In view of the paltern of circulating APRs after LPS exposure in the pulmonary compartment, these results indicate that hepatic expression of APR genes contributed to the increased plasma levels of SAP, LBP, and AGP.

Figure 3. Transcription of SAP, LBP, AGP, and $\alpha_{4}$-AT in liver as determined by RT.PCR. Total RNA was isolated from liver tissue of age-matched control mice [C], saline-treated mice [S], and LPS-challenged mice killed ait $4 \mathrm{~h}, 24 \mathrm{~h}$ or $72 \mathrm{~h}$. Messienger RNA expression levels of SAP (280 bp), LBP (340 bp), AGP (390 bp), $\alpha_{4}$-AT (350 bp), and B-actin (348 bp) were analyzed using RT-PCR $(n=3$ per group $)$. Equal intensity of B-actin mRNA bands confirmed equal loading of CDNA in RT-PCR. One representative experiment from a series of three is shown.

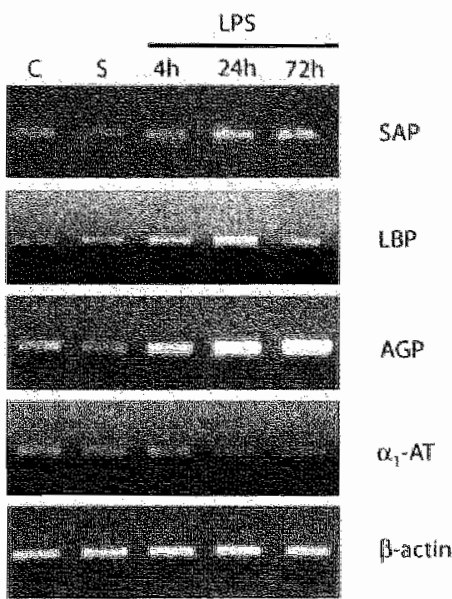

\section{IL-6 links pulmonary inflammatory response and hepatic APR expression}

Systemic LPS administration is known to result in a hepatic acute-phase response that is dependent on both $\mathrm{TNF}_{-} \alpha$ and IL- $6^{24,33}$. To examine if these cytokines are also important mediators in APR production by hepatocytes in response to pulmonary LPS exposure, we first examined mRNA expression levels of TNF- $\alpha$ and IL-6 in the lung using RT-PCR. As shown in Figure 4, IT LPS administration results in upregulation of TNF- $\alpha$ and IL- 6 from 4 h after exposure. Additionally, we determined IL- 6 and TNF- $\alpha$ levels in plasma. As shown in Figure 5 , circulating levels of IL-6 were significantly increased at 4 h after IT LPS exposure. In contrast, TNF- $\alpha$ was not detectable in plasma at any time points examined. Therefore, we also measured plasma levels of soluble receptors for TNF- $\alpha$ (sTNF-R55 and sTNF-R75), which are considered to be markers of TNF activation. As demonstrated in Figure $5 B$, constitutive levels of sTNF- $R$ were found in saline-treated and untreated control animals, but IT LPS challenge did not result in a significant increase in plasma levels of sTNF-R. Taken together, these data point at IL-6 but not TNF- $\alpha$ as possible mediator between lung and liver in the situation of systemic acute-phase response induced by pulmonary LPS exposure. 
Figure 4. Transcription of TRF-o and IL-6 in lung as determined by RT-PCR. Total RWA was isolated from lung tissue of age-matched control mice [C], saline-ireated mice 1SH, and LPS-challenged mire killed at $4 \mathrm{~h}, 24 \mathrm{~h}$ or $72 \%$. Messenger RUA expression levels of TNF-0 $(307$ bp) and $1 \mathrm{~L}-6$ (318 bp), and Bartin $(348 \mathrm{bp})$ were

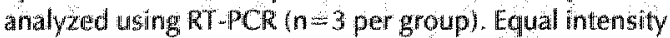
of B-actin m 1 MA band confirmed equal loading of $6 \mathrm{DNA}$ in RT-PCR. One representative experiment from a series of three is sthown.

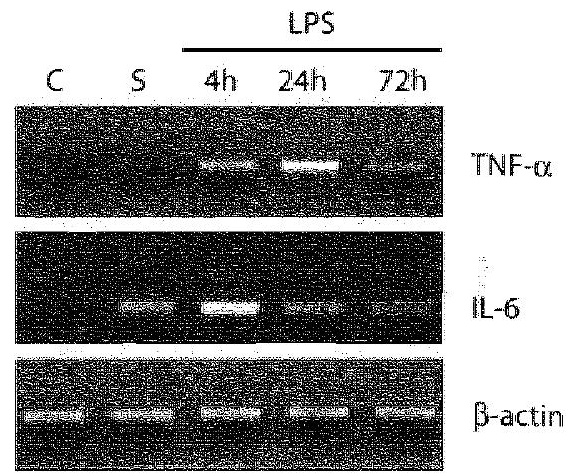

\section{DISCUSSION}

The present study demonstrates that local exposure to LPS induced rapid expression of three major APRs, namely ACP, $\alpha_{1}-\mathrm{AT}$, and LBP in the lung. To our knowledge, this is the first paper to demonstrate increased $\alpha_{1}$-AT expression in lung tissue as well as absence of SAP expression after IT LPS exposure. To ascertain protein production, we performed broncho-alveolar lavage (BAL) and measured acute-phase protein concentrations in BAL fluid (data not shown). Although we were able to demonstrate elevated levels of LBP in BALF from $24 \mathrm{~h}$ post-exposure, we considered these findings unreliable as elevated levels of $\lg G$ were also measured, indicating increased vascular permeability allowing the leakage of plasma APRs into the alveolar spaces (data not shown). A second strategy to prove local protein production was immunohistochemical detection of cytoplasmic APRs in lung sections. As APRs are known to be very sticky and positive staining in the lung may therefore be due to binding of plasma APRs to endothelial cells, lungs were flushed ex vivo before fix-
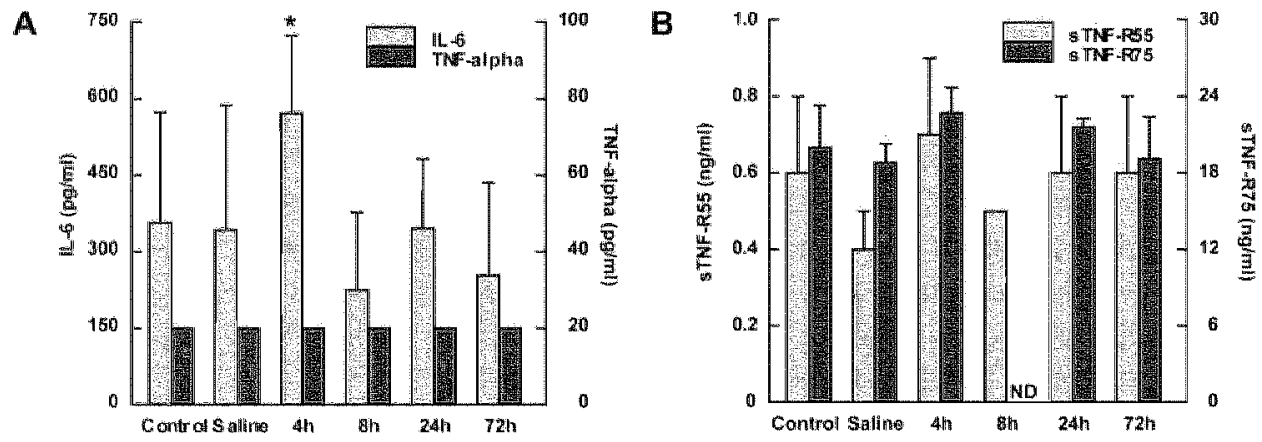

Figure 5. Analysis of plasma levels of IL-6, TNF- $\alpha$, and sTNF-receptors after IT LPS instillation. Mice received 5 Hg of LPS IT and were sacrificed $4,8,24$ and 72 hours after instillation. Saline-ireated mice were killed 24 hours after instillation. Plasma levels of (A) IL-6 and TNF- $\alpha$ as well as (B) STNF-R55 and sTNF-R75 were measured by specific sandwich ELISA ( $n=6$ per group). Data are expressed as mean $\pm S E M$. Significant increases in mean plasma levels compared with control are indicated by $*(P<0.05)$; $N D=$ not done. 
ation of the tissue. Unfortunately, the background staining remained dominant despite flushing, hereby making proper judgement of the cytoplasmic staining of APRs not possible (data not shown).

Our findings are in line with previous studies in rats demonstrating upregulation of MRNA for AGP and LBP in the lung after IT LPS exposure ${ }^{22,34}$. In addition, recent in vitro studies suggested that resident lung cells are able to express APRs. We and others previously reported that stimulation of human primary type II alveolar cells as well as respiratory cell lines derived from type II pneumocytes resulted in increased levels of LBP, AGP and fibrinogen ${ }^{21 \cdot 23}$. In addition, human alveolar macrophages were reported to express genes for $\mathrm{AGP}, \mathrm{CRP}$ and $\alpha_{4}$-AT upon stimulation ${ }^{32.35 .35}$. Furthermore, human microvascular endothelial cells were reported to produce $\mathrm{AGP}^{3}{ }^{3}$. We therefore speculate that resident lung cells are a possible source of APRs in the lung after local LPS exposure.

The present study demonstrates that local LPS exposure has also extrapulmonary effects. We found elevated levels of AGP, LBP, and SAP in the circulation after exposure to LPS in the pulmonary compartment. This is in line with previous studies, showing elevated plasma levels of LBP and CRP (closely related to SAP) after inhalation of endotoxin in healthy human subjects ${ }^{6,13.14}$. In addition, pulmonary infection with Pasteurella haemolytica in calves resulted in 4-fold increase in serum LBP levels ${ }^{38}$. Comparison of systemic acute-phase response induced by local and systemic LPS administration in mice reveals that local LPS exposure results in a relative mild acute-phase response, as up to hundred-fold elevated serum levels of APRs are reported after systemic LPS in mice ${ }^{24,39}$. However, it is not clear if this discrepancy is caused by the route of administration, or by relative high doses of LPS used in sepsis models.

When comparing APR expression and kinetics in lung and liver to elucidate the source of the elevated circulating APRs after local LPS exposure, we found that the hepatic APR expression pattern was consistent with the APR levels found in plasma. This indicates that circulating APRs elevated upon treatment with LPS originate from hepatocytes. We speculate that IL-6 is one possible mediator between the pulmonary and hepatic system, because circulating levels of IL- 6 - not TNF- $\alpha$ - were found to be increased after local LPS exposure despite significant upregulation of mRNA levels for both IL-6 and TNF- $\alpha$ in the lung. This discrepancy may be due to the time points chosen, through which we may have missed an early peak of TNF- $\alpha$ in plasma at 1-2 hours. On the other hand, Nelson and colleagues reported compartmentalization of TNF- $\alpha$ induced by either intra-alveolar or systemic LPS exposure ${ }^{40}$. Additionally, the fact that plasma levels of both sTNF-receptors, considered to be markers of TNF activation, remained unchanged, suggests that IL- 6 but not TNF- $\alpha$ is involved in the hepatic acute-phase response induced by pulmonary LPS exposure. However, we cannot exclude that additional mediators not investigated in this study may al so be involved.

The question raises as to which physiologic role APRs produced by lung and liver may play in the innate immune response against Gram-negative bacteria. LBP and SAP are major acute-phase reactants in the mouse that share the capacity to bind to LPS $^{9,15}$. LBP strongly enhances sensitivity of cells for LPS by facilitating binding of LPS 
to CD14, resulting in intracellular signalling via the TLR-4/MD-2 pathway. Binding of $\angle B P$ to gram-negative bacteria has also been reported ${ }^{43}$, which results in phagocytosis and clearance of these microorganisms ${ }^{43}$. Therefore, local production of LBP may assist in the clearance of bacteria as well as enhance the local inflammatory response. In addition, LBP accelerates the transport of LPS into lipoproteins in the blood, hereby leading to neutralization of LPS leaking from the pulmonary compartment ${ }^{43,44}$.

AGP is a highly negatively charged glycoprotein (reviewed by Fournier ${ }^{16}$ ) that was shown to inhibit neutrophil activation ${ }^{45}$, modulate LPS-induced cytokine secretion by monocytes/macrophages ${ }^{46}$, and induce macrophage derived IL-1 receptor antagonist (IL-1RA) release ${ }^{47}$. In addition, in vivo studies demonstrated exogenous AGP to reduce leukocyte infiltration and alveolar edema in LPS-induced acute lung injury and to prevent apoptosis and inflammation during renal ischemia/reperfusion injury ${ }^{29}$. This suggests that local expression of AGP may significantly protect against the deleterious effects of inflammation in the alveolar space, where the integrity of the structure is essential for the maintenance of lung function. Systemically, rapid induction of serum AGP levels has been reported to protect mice from lethal Gram-negative infection ${ }^{49}$. In this view, elevated circulating AGP may act as a negative feedback mechanism aimed at limiting the extent of the systemic inflammatory reaction.

In contrast to LBP and AGP, the physiological functions of SAP, a member of the family of pentraxins, are still not completely understood. Binding of SAP to numerous ligands has been reported, including LPS and bacteria (reviewed by De Haas ${ }^{50}$ ). In addition, De Haas et al. demonstrated that a SAP-derived peptide protected against LPS-induced septic shock in mice ${ }^{15,51}$. Therefore, systemic elevation of SAP induced by LPS exposure to the lung may play a role in the binding as well as clearance of hostor pathogen-derived cellular debris.

The major function of $\alpha_{1}-$ AT is inhibition of neutrophil elastase, hereby providing the lung protection from proteolytic digestion by harmful proteases that may eventually result in loss of lung recoil and emphysema ${ }^{19}$. Furthermore, $\alpha_{1}-\mathrm{AT}$ is known to inhibit neutrophil superoxide production ${ }^{17}$, and induce macrophage-derived IL-1RA release" ${ }^{1 /}$. In these respects, expression of $\alpha_{1}$-AT at the initial site of injury, like LBP and AGP, may have anti-inflammatory properties protecting against the deleterious effects of the acule inflammatory response.

Taken together, locally produced APRs may control the early phase of specific local responses to injury and infection before inflammation induces capillary leakage and extravasation of serum proteins. The hepatic acute-phase response may occur as a late event preventing further spreading of the LPS and local inflammation. As local production of APRs results in higher concentrations in the intra-alveolar compartment and also shortens the time path, this would be more efficient than extravasation of serum APRs. Further studies are clearly required to study the contribution of individual APRs produced in lungs to inflammation induced by exposure to bacterial endotoxin.

In summary, the current study shows that local LPS exposure in mice resulted in a rapid increase of mRNA expression for three major APRs ( $\alpha_{1}-\mathrm{AT}, \mathrm{AGP}$, and LBP) in the lung. In addition, exposure to LPS in the pulmonary compartment resulted in elevated levels of AGP, LBP, and SAP in the circulation, which was consistent with the APR 
expression pattern in the liver. Furthermore, we demonstrated increased plasma IL-6 levels after local LPS exposure, suggesting that IL-6 acts as mediator between the pulmonary and hepatic system. In clinical medicine, measurement of serum APRs is considered to be a valuable tool for rapid diagnosis of infection, monitoring of the disease and the patient's recovery. On the basis of the observed differences between the systemic acute-phase response and the local acute-phase response in mice, we suggest that the comparison of APRs present in bronchoalveolar lavage (BAL) fluid and serum could potentially give information on the origin of an inflammatory response due to infection being either local or systemic. Studies in patients are currently being performed to explore the application of APR pattern analysis in clinical medicine.

\section{ACKNOWLEDGEMENTS}

The authors thank T.M. Jeunhomme for developing the murine IL-6 ELISA and R. Duisters for expert technical assistance. This study was supported by a grant from Glaxo Wellcome, The Netherlands.

\section{REFERENCES}

1. Kline JN, Cowden JD, Hunninghake GW, Schutte $\mathrm{BC}$, Watt $J \mathrm{~L}$, Wohlford Lenane $\mathrm{CL}$, Powers LS, Jones MP, and Schwartz DA. Variable airway responsiveness to inhalud lipopolysaccharide. Am / Respir Crit Care Med 1999;160:297-303.

2. Rylander $R$, Haglind $P$, and Lundhol $m$ M. Endotoxin in cotton dust and respiratory function decrement among cotton workers in an experimental cardroom. Am Rev Respir Dis 1:985;131:209-213.

3. Del A, Godshali MA, and Palmgren MS. Gram-negative bacterial endotoxins in grain elewator dusts. Am Ind Hyg Assoc) 1984,45:336-339.

4. Michel O, Kips I, Duchateau I, Vertongen F, Robert L, Collet H, Pauwels R, and Sergysels R. Severity of asthma is related to endotoxin in house dust. Am J Respir Crit Care Med 1996; 54:1641-1646.

5. Hasday JD, Bascom $R_{*}$ Costa Jl, Fitzgerald $T$, and Dubin W. Bactarial endotoxin is an active component of cigarette smoke. Chest 1999;115:829-835.

6. Michel O, Nagy AM, Schroewen M, Duchateau J, Newe J Fondu P, and Sergysels R. Dosemesponse relationship to inhaled endotoxin in normal subjects. An / Respir Crit Care Med 1997;156,1157. 1164.

7. Michel $O$, Duchateau $\downarrow$, and Sergysels $\mathbb{R}$. Effect of inhalled endotoxin on bronchial reactivity in asthmatic and normal subjects. / Appl Physiol 1989:66:1059-1064.

8. Cawagna $G$, Foa V, and Vighani EC. Effects in man and rabbits of inhalation of colton dust or extracts and purfifed endotoxin5. Br J Ind Med 1969,26:314-321.

9. Alexander $\mathrm{C}$, and Rietschel ET. Bacterial lipopolysaccharides and innate immunity. Endotoxin Res $2001 ; 7: 167-202$

10. Vernooy JH, Dentener MA, van Suylen RI, Buurman WA, and Wouters. EF. lintratracheal Instilliation of Lipopolysaccharide in Mice Induces Apoptosis in Bronchial Epithellial Cells. No role for tumor necrosis factor-alpha and infiltrating neutrophils. Am / Respir Cell Mol Brol 2001;24:569-576.

11. Clapp WD, Thorne PS, Frees $K L$, Zhang $X, L u \times C R$, and Schwatz DA. The effects of inhalation of grain dust extract and endotoxin on upper and lower alirways. Chest 1993;104:825-830.

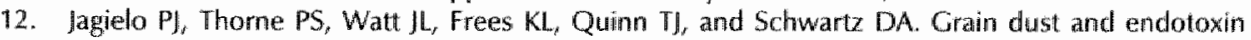
inhalation challenges produce similar inflammatory responses in normal subjects. Chest $1996 ; 110: 263-270$. 
13. Michel $O$, Dentener $M$, Corazza $F$, Buiman $W$, and Rylander R. Healthy subjects express differences in clinical responses to inhaled lipopolysaccharide that are related with inflammation and with atopy. I Allergy Clin Immurol 2001;107:797-804.

14. Michel O, Duchateau ), Plat $G$, Cantinieatx B, Hotimsky A, Geraim J, and Sergysels R. Blood inflammatory response to inhated endotoxin in normal subjects. Clin Exp Allergy 1995;25:73-79.

15. De Haas Cl, wan der Tol ME, Van Kessel KP, Verhoef J, and Van Strijp $\mathbb{A} A$. A synthetic lipopolysaccharide-biniding peptide based on amino acids $27-39$ of serum amyloid $P$ component inhibits lipopolysaccharide-induced responses in human blood / /mmunol 1998;161:3607-3615.

16. Foumier T, Medjoubi NN, and Porquet D. Alpha-1-acid glycoprotein. Biochim Biophys Acta $2000 ; 1482: 157-171$

17. Bucurenci $N$, Blake $D R$, Chidwick $K$, and Winyard PG. Inhibition of neutrophil superoxidle production by human plasma alpha 1-antitrypsin. FEBS Lett 1992:300:21-24.

18. Tilg $H$, Vannier $E$, Vachino $G$, Dinarello $\mathrm{CA}$, and Mier $\mathrm{JW}$, Antiinflammatory properties of hepatic acute phase proteins: preferential induction of interleukin 1 (IL-1) receptor antagonist over $\mathrm{LL}-1$ beta syrithesis by human peripheral blood mononuclear cells. J Exp Med 1993:178:1629-1636.

19. Reid PT, and Sallemave $\mathbb{M}$. Neutrophil-derived elastases and their inhibitors: potential role in the pathogenesis of lung disease. Curr Opin Investig Drugs 2001;2:59-67.

20. Suffredini AF, Fantuzzi G, Badolato R, Oppenheim IJ, and OGrady NP. New insights into the biology of the acute phase response. 1 Cin Immunol 1999;19:203-214.

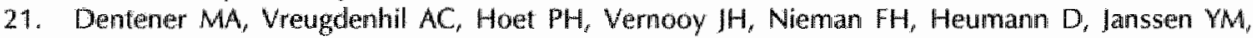
Buurman WA, and Wouters EF. Production of the acute-phase protein lipopolysaccharide-binding protein by respiratory type II epithelial cells: implications for local defiense to bacterial endotoxins. Am J Respir Cell Mol Biol 2000,23:146-153.

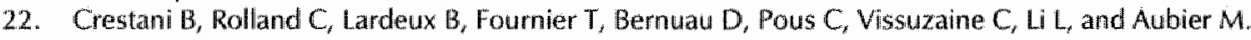
Inducible expression of the alpha1-acid glycoprotein by rat and human type ll alveolar epithelial cells. IImmunol 1998;160:4596-4605.

23. Guadiz $G_{*}$ Sporn LA, Goss RA, Lawrence SO, Marder VJ, and Simpson Haidlaris PJ. Polarized secretion of fibrinogen by lung epithelial cells. Am / Respir Cell Mol Biol 1997; 17:60-69.

24. Bopst $M$, Haas $C_{r}, C a r B$, and Eugster HP. The combined inactivation of tumor necrosis factor and interleukin-6 prevents induction of the major acute phase proteins by endotoxin. Eur / Immunol $1998 ; 28: 4130-4137$.

25. Xing $\mathrm{Z}$, Gauldie $J_{,}$Cox $\mathrm{G}_{,}$Baumann $\mathrm{H}_{*}$ Jordana $\mathrm{M}$, Lei $X \mathrm{~F}$, and Achong $M K$. IL-6 is an antiunflammatory cytokine required for controlling local or systemic acute inflammatiory responses. / Clin Invest $1998 ; 101: 311-320$.

26. Schumann RR, and Zweigner J. A novel acute-phase marker: lipopolysaccharide binding protein (LBP). Clin Chem Lab Med 1999;37:271-274.

27. Minnich $M$, Kueppers $F$, and James $H$. Alpha-1-antitrypsin from mouse serum isolation and characterization. Comp Biochem Physiol B 1984;78:413-419.

28. Le Roy $D$, Clauser MP, and Heumamn D. LPS binding protein (LBP) function in germfree mice.) Endotox Res 1997;:18:3187.

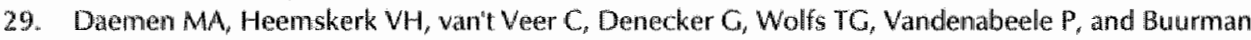
WA. Functional protection by acute phase proteins alpha(1)-acid glycoprotein and alpha(1)antitrypsin against ischemiareperfusion injury by preventing apoptosis and inflammation. Circulation $2000 ; 102: 1420-1426$.

30. Dentener MA, Greve JW, Maessen JG, and Buurman WA. Role of tumour necrosis factor in the enhanced sensitivity of mice to endotoxin after exposure to lead. Immunopharmacol Immunotoxicol $1989 ; 11: 321-334$.

31. Bemelmans $M H$, Gouma DJ "and Buurman WA. LPS-induced sTNF-receptor release in vivo in a murime model. Inwestigation of the role of tumor necrosis factor, IL-1, leukemia inhibiting factor, and IF

32. Foumier $T$, Bouach $N$, Delafosse $C$, Crestani $B$, and Aubier $M$. Inducible expression and regulation of the alpha 1-acid glycoprotein gene by alveolar macrophages: prostaglandin E2 and cyclic AMP act as new positive stimuli. J lmmunol 1999;163:2883-2890.

33. Sharma R, Macallan DC, Sedgwick P, Remick DG and Girifin GE. Kinetics of endotoxin-induced acute-phase protein gene expression and its modulation by TNF-alpha monodlonal antibody. Am I Physiol 1992:262: R7866-793. 
34. Klein RD, SU GL, Aminlari A, Alarcon WH, and Wang SC. Pulmonary LPS-binding protein (LBP) upregulation following LPS-mediated injury. / Surg Res 1998; 78:42-47.

35. Dong $Q$ and Wright IR. Expression of C-reactive protein by alveolar macrophages I Immonol $1996 ; 156: 4815-4820$.

36. Mornex JF, Chytil-Weir $A$, Martinet $Y$, Courtney $M$, LeCocq JP, and Crystal RG. Expression of the alpha-1-antitrypsin gene in mononuclear phagocytes of normal and alpha-1-antitrypsin-deficient individuals. J Clin Invest 1986;77:1952-1961.

37. Sorensson 1, Matejka GL, Ohlson $\mathrm{M}$, and Haraldsson B. Human endothelial cells produce orosomucoid, an important component of the capillary barrier. Am / Physiof 1999;276:H530-534.

38. Horadagoda NU, Eckersall PD, Andrew L, Gallay P, Heumann D, and Gibbs HA. Characterisation of bovine lipopolysaccharide binding protein and the in vivo acute phase response to Pasteurella haemolytica Type A. Vet Immunal Inmunopathol 1995;49:61-74.

39. Lamping N, Dettmer R, Schroder NW, Pieil D, Hallatschek W, Burger R, and Schumann RR. LPSbinding protein protects mice from septic shock caused by LPS or gram-negative bacteria. / Clin Invest 1998;101:2065-2071.

40. Nelson S, Bagby GJ, Bainton BG, Wilson LA, Thompson IJ, and Summer WR. Compartmentalization of intraalveolar and systemic lipopolysaccharide-induced tumor necrosis factor and the pumonary inflammatory response. I Infect Dis 1989;159:189-194.

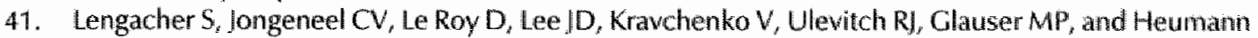
D. Reactivity of murine and human recombinant LPS-binding protein (LBPI within LPS and gram negative bacteria. J Inflamm 1995;47:165-172.

42. Grunwald $U$, Fan X, Jack RS, Workalemahu G, Kallies A, Stelter $\mathbb{H}^{*}$, and Schutt C. Monocytes can phagocytose Gram-negative bacteria by a CD1 4-dependent mechanism. JImmunol 1996;157:4119. 4125.

43. Vreugdenhil AC, Snoek AM, wan te Veer $C$, Greve $J$, and Buurman WA. LPS-binding protein circulates in association with apoB-containing lipoproteins and enhances endotoxin-LDLNLDL. interaction. I Clin Invest 2001;107:225-234.

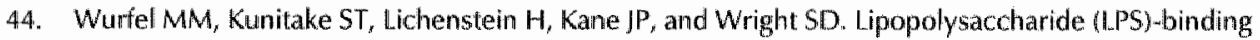
protein is carried on lipoproteins and acts as a cofactor in the neutralization of LPS. J Exp Med 1994:180:1025-1035.

45. Laine $E$, Couderc $R$, Roch-Arveiller $M_{r}$ Vasson MP, Giroud JP, and Raichvarg D. Modulation of human polymorphonuclear neutrophil functions by alpha 1-acid glycoprotein. Inflammation 1990;14:1-9.

46. Boutten $A$, Dehoux $M$, Deschenes $M$, Rouzeau JD, Bories $P N$, and Durand $G$. Alpha 1-acid glycoprotein potentiates lipopolysaccharide-induced secretion of interleukin-1 beta, interleukin- 6 and tumor necrosis factor-alpha by human monocytes and alveolar and peritoneal macrophages. Eur $J$ Immunol $1992 ; 22: 2687-2695$.

47. Bories PN, Feger J, Benbernou N, Rouzeau JD, Agneray J, and Durand G. Prevalence of tril- and tetrantennary glycans of human alpha 1-acid glycoprotein in release of macrophage inhibitor of interleukin-1 activity. Inflammation 1990;14:315-323.

48. Muchitsch EM, Varadi $K$, and Pichler L. Effects of alpha 1 -acid glycoprotein on acute pancreatitis and acute lung injury in rats. Arzneimittelforschung 2000; $50: 987-994$.

49. Hochepied T, Van Molle W, Berger FG, Baumann $H$, and Libert $C$. Involvement of the acute phase protein alpha 1 -acid glycoprotein in nonspecific resistance to a lethal gram-negative infection. / Biol Chem 2000;275:14903-14909.

50. de Haas $\mathrm{CJ}$. New insights into the role of serum amyloid $\mathrm{P}$ component, anovel lipopolysaccharidebinding protein. FEMS Immunol Med Microbiol 1999;26:197-202.

51. de Haas Cl, van der Zee R, Benaissa-Trouw B, van Kessel K. , Verhoef J, and van Strijp JA. Lipopolysaccharide (LPS)-binding synthetic peptides derived from serum amyloid P component neutralize LPS. Infect Immun 1999;67:2790-2796. 


\title{
CHAPTER 9
}

\section{Long-term intratracheal lipopolysaccharide exposure in mice results in chronic lung inflammation and persistent pathology}

Juanita H.J. Vernooy', Mieke A. Dentener', Robert J. van Suylen², Wim A. Buurman', Emiel F.M. Wouters'

Departments of ${ }^{1}$ Respiratory Medicine, ${ }^{2}$ Pathology and ${ }^{3}$ General Surgery, University Hospital Maastricht, Maastricht, The Netherlands

American Journal of Respiratory Cell and Molecular

Biology 2002; 26: 152-159

\begin{abstract}
Lipopolysaccharide (LPS), a major proinflammatory glycolipid component of the Gram-negative bacterial cell wall, is one of the agents ubiquitously present as a contaminant on airborne particles, including air pollution, organic dusts, and cigarette smoke. Chronic exposure to significant levels of LPS is reported to be associated with the development and/or progression of many types of lung diseases, including asthma, chronic bronchitis, and progressive irreversible airflow obstruction, that are all characterized by chronic inflammatory processes in the lung. In the present study, pathologic effects of long-term LPS exposure to the lung were investigated in detail. To this end, a murine model in which mice were exposed to repeated intratracheal instillation of Escherichia coli LPS was developed. We show that long-term LPS instillation in mice results in persistent chronic pulmonary inflammation, characterized by peribronchial and perivascular lymphocytic aggregates (CD4+, CD8t, and CD19+), parenchymal accumulation of macrophages and CD8 $+T$ cells, and altered cytokine expression. Furthermore, airway and alveolar alterations such as mucus cell metaplasia, airway wall thickening, and irreversible alveolar enlargement accompanied the chronic inflammatory response. Interestingly, the observed inflammatory and pathologic changes mimic changes observed in human subjects with chronic inflammatory lung diseases, especially chronic obstructive pulmonary disease (COPD), suggesting that this murine model could be applicable to dissect the role of inflammation in the pathogenesis of these disease conditions.
\end{abstract}




\section{INTRODUCTION}

The respiratory system is continuously exposed to the external environment via the air inhaled, which contains numerous potentially harmful agents. Lipopolysaccharide (LPS), a major proinflammatory glycolipid component of the Gram-negative bacterial cell wall, is one of the agents ubiquitously present as contaminant on airborne particles, including air pollution, organic dusts ${ }^{2.3}$, and cigarette smoke ${ }^{4}$. In ambient breathing air, LPS is measured at very low concentrations $\left( \pm 0.4 \mathrm{ng} / \mathrm{m}^{3}\right)^{5}$. Under these conditions, the lung has efficient defense mechanisms against airborne LPS, including the mucociliary system, antimicrobial compounds in the epithelial lining fluid, and alveolar macrophages. Experimental inhalation of a high LPS dose, however, provokes the innate immune system in healthy human subjects, resulting in an acute inflammatory response, which manifests itself at both the pulmonary and the systemic level. In addition, this response is accompanied by clinical symptoms, including fever and airflow decline $e^{6, \%}$. Extensive studies investigating acute inflammation using laboratory animals have demonstrated that LPS activates alveolar macrophages via LPSbinding protein (LBP)/CD14/Toll-like receptor (TLR)-4-dependent pathway to produce specific cytokines, resulting in a rapid but transient neutrophil infiltration into the lung (interstitium, alveoli, and airway).

In contrast to short-term LPS exposure, chronic exposure to significant levels of LPS is reported to be associated with the development and/or progression of many types of lung diseases, including asthma, chronic bronchitis, and progressive irreversible airflow obstruction, all characterized by chronic inflammatory processes in the lung. Michel and colleagues reported that the concentration of LPS in the domestic setting is associated with the clinical severity of asthma? Moreover, individuals with asthma ${ }^{10}$ and those with chronic bronchitis ${ }^{11}$ develop airflow obstruction at lower concentrations of inhaled LPS compared with healthy subjects, and thus respond more sensitively to LPS. Chronic occupational exposure to LPS contained in organic dusts, such as grain dust and swine dust, is known to result in airflow obstruction among agricultural workers. In addition, the concentration of inhaled LPS (not dust) in the workplace bioaerosol is strongly and consistently related to respiratory symptoms and airflow obstruction ${ }^{12,13}$. Furthermore, follow-up studies have shown that long-term average exposure to LPS-laden dusts resulted in a profound pulmonary inflammatory response related to longitudinal decline in lung function ${ }^{14}$, and thus irreversible and progressive lung pathology. Recently, bioactive LPS is reported to be present at high levels in cigarette smoke, which suggests that LPS is an important pathogenic substance in cigarette smoke contributing to the pulmonary diseases that develop in susceptible cigarette smokers. Taken together, these studies indicate that LPS may have a larger role in the pathogenesis of chronic lung diseases than previously realized. However, the extent to which inflammatory processes contribute to lung pathology observed in the lungs of these patients is still poorly understood.

In the present study, pathologic effects of long-term LPS exposure to the lung were investigated in detail. To this end, we developed a murine model in which 
mice were exposed to multiple intratracheal instillations of Escherichia colf LPS. We show that repeated intratracheal LPS instillation in mice results in persistent chronic pulmonary inflammation with altered cytokine expression, accompanied by airway and alveolar alterations. Interestingly, the observed inflammatory and pathologic changes mimic changes observed in hurman subjects with chronic pulmonary inflammatory disorders, especially chronic obstructive pulmonary disease (COPD), suggesting that this murine model is applicable to dissect the role of inflammation in the pathogenesis of these disease conditions.

\section{MATERIAL \& METHODS}

\section{Antibodies}

Monoclonal antibody (mAb) Gr-1 (rat anti-mouse Ly-G6) was obtained from PharMingen (San Diego, CA). mAb Moma-2 (rat anti-mouse macrophage/monocytel was a kind gift from Prof. G. Kraal (Free University, Amsterdam). mAb 6D5 (rat anti-mouse CD19) was obtained from Serotec (Oxford, UK). Hybridoma cell lines GKT.5 (rat anti-mouse CD4), 53-6.72 (rat antimouse CD8), and THB120 (rat anti-murine major histocompatibility complex (MHC) class II) were obtained from the American Type Culture Collection (Rockville, MD). mAb $\alpha$-SMA-FITC (fluorescein isothiocyanate-conjugated mouse anti-human smooth muscle actin) was obtained from Sigma Chemical Co. (St. Louis, MO). mAb MIB-1 (mouse anti-human peptide Ki-67) was obtained from Immunotech (Marseille, France). Control mAb GL113 (rat IgG) was a gift from Dr. Savelkoul (Erasmus University, Rotterdam, The Netherlands).

\section{Animals}

Male Swiss mice $\sim 12$ wk old were obtained from Charles River Breeding Laboratories (Heidelberg, Germany). Animals were housed individually in standard laboratory cages and allowed food and water ad ibitum throughout the experiments. The studies were performed under a protocol approved by the Institutional Animal Care Committee of the Maastricht University.

\section{Experimental protocol}

Mice were repeatedly challenged with LPS $(E$. coli, serotype O55:B5, Sigma Chemical Co.) twice a week for a period of $12 \mathrm{wk}$ by intratracheal instillation in an attempt to induce a chronic pulmonary inflammation. The dose of LPS used was 5 $\mu \mathrm{g} /$ instillation/mouse, which corresponds to the LPS dose delivered to the human lung by smoking of $\sim 25$ cigarettes $^{4}$. No signs of an overall toxic effect at the dose of LPS employed were observed in the trachea, airways, and lungs. Sham mice were instilled intratracheally with LPS-free sterile $0.9 \% \mathrm{NaCl}$, whereas control mice received no treatment. Intratracheal instillation was performed by a nonsurgical technique as described previously $y^{3}$. In brief, mice were anesthetized by intraperitoneal injection of xylazin/ketamin. A volume of $50 \mu \mathrm{l}$ was instilled intratracheally via a canule, followed by $0.1 \mathrm{ml}$ of air. After intratracheal treatment, 
the mice were kept in an upright position for 10 min to allow sufficient spreading of the fluid throughout the lungs. Thirty mice were divided into four experimental groups. LPS +1 group $(\mathrm{n}=10)$ : intratracheal exposure to $5 \mu \mathrm{g} \mathrm{LPS}$; mice were killed 1 wk after the final intratracheal instillation (1-wk recovery period) to allow acute inflammatory changes that occur after each LPS exposure to subside. LPS +8 group $(n=5)$; intratracheal exposure to $5 \mu \mathrm{g}$ LPS; mice were killed 8 wk after the final intratracheal instillation (8-wk recovery period) to study the ongoing character of the induced pathogenesis. Saline group $(n=10)$ : intratracheal instillation of $50 \mu \mathrm{l}$ sterile saline; mice were killed $1 \mathrm{wk}$ after the final intratracheal instillation. Control group $(n=5)$ : age-matched control mice.

\section{Histologic analysis}

After thoracotomy, the left lung was prepared for light microscopy. Lung tissue was inflated with $10 \%$ phosphate-buffered formalin $(\mathrm{pH}=7.4)$ at a pressure of 20 $\mathrm{cm} \mathrm{H}_{2} \mathrm{O}$ through the trachea for $15 \mathrm{~min}$ and subsequently fixed in formalin for 24 h. After paraffin embedding, $4 \mu \mathrm{m}$ sections were cut and stained with hematoxylin/eosin (H\&E) to evaluate general morphology; or periodic acid-Schiff (PAS)/Alcian blue to determine the presence of mucin glycoconjugates.

\section{Immunohistochemistry}

Inflammatory cells were characterized by immunohistochemistry on frozen sections. Lung tissue of the right lung was infused with $20 \%$ sucrose $/ 50 \%$ TissueTek OCT compound (Sakura Finetek Europe BV; Zoeterwoude, The Netherlands) and slowly frozen in TissueTek OCT on dry ice. Consecutive sections of 5-7 $\mu \mathrm{m}$ thickness were cut, fixed in acetone, and stored at $20^{\circ} \mathrm{C}$ until use. Sections were rehydrated in tris-buffered saline, $\mathrm{pH} \mathrm{7.8,} \mathrm{and} \mathrm{endogenous}$ peroxidase was quenched with $0.3 \% \mathrm{H}_{2} \mathrm{O}_{2}$. To prevent nonspecific binding of antibodies, sections were blocked with $5 \%$ normal goat serum. Sections were stained with mAbs for detection of neutrophils (Gr-1), macrophages (Moma-2), CD4+ T-lymphocytes (GK1.5), CD8 + T-lymphocytes (53-6.72), B-lymphocytes (6D5), and cells expressing MHC class II antigen (TIB120). After washing, peroxidase-conjugated goat anti-rat IgG Ab (Jackson, West Grove, PA) preincubated with $5 \%$ normal mouse serum was applied as the secondary detection Ab. Enzymatic reactivity was visualized with 3-amino-9-ethylcarbazole (AEC). Sections were counterstained with hematoxylin and mounted. No significant staining was detected in slides incubated with control $\mathrm{mAb}$ (GL113) instead of the primary detecting $\mathrm{mAb}$, indicating the absence of significant background staining.

Immunohistochemistry for $\alpha$-smooth muscle actin ( $\alpha$-SMA) was performed as described previously ${ }^{15}$. In brief, $4 \mu \mathrm{m}$ paraffin sections were deparaffinized and endogenous peroxidase was quenched with $0.3 \% \mathrm{H}_{2} \mathrm{O}_{2}$ in $100 \%$ methanol. $\alpha-S M A$ was detected using FITC-labeled $\alpha$-SMA mAb followed by peroxidase-labeled antiFITC pAb (Boehringer Mannheim BV, Almore, The Netherlands), and developed with the chromogen 3,3'-diaminobenzidine. Sections were counterstained with hematoxylin and mounted. 
Proliferating cells were detected by immunohistochemistry on 4 fm paraffin sections using SuperFrost Plus slides (Menzel-Gläser, Braunschweig, Germany). After deparaffinization, endogenous peroxidase was quenched with $0.3 \% \mathrm{H}_{2} \mathrm{O}_{2}$ in $100 \%$ methanol. Antigen was unmasked by heating the sections for $15 \mathrm{~min}$ in 10 $\mathrm{mM}$ citrate buffer $\mathrm{pH} 6.0$ using a microwave, followed by 60 min cooling in the same buffer. Proliferating cells were detected by incubating the sections with mAb $\mathrm{Ki}-67$ (MIB-1) for $30 \mathrm{~min}$ at $37^{\circ} \mathrm{C}$. M.O.M. immunodetection kit (Vector Laboratories, Burlingame, $C A$ ) was used according to the manufacturer's instructions. The M.O.M. kit significantly reduced background staining caused by the inability of the anti-mouse secondary antibody to distinguish between the mouse primary antibody and endogenous mouse immunoglobulins in the tissue. The peroxidase-labeled secondary antibody was visualized with AEC. Sections were counterstained with hematoxylin and mounted.

\section{Morphologic and morphometric analyses}

Lymphocytic aggregates (cutoff value $>50$ lymphocytes/aggregate) were counted on H\&E-stained lung sections in the hilar region (magnification $\times 50$ ) by two independent observers unaware of the experimental conditions. Results are expressed as the number of aggregates/section (corrected for surface area).

Intra-alveolar macrophages recognized by general morphology on H\&E-stained paraffin sections were enumerated for each section on ten randomly chosen fields (divided into $10 \times 10$ squares), which represents a total area of $2.5 \mathrm{~mm}^{2}$. This area was sufficient to obtain a mean value per subject that remained rather constant after further increase of the number of fields examined. Intra-alveolar macrophages were counted at a magnification of $\times 200$ by two independent observers unaware of the experimental conditions. Results are expressed as the number of macrophages $/ \mathrm{mm}^{2}$.

Lymphocyte subsets recognized by specific immunohistochemical staining on frozen sections were scored on a 4-point scale by one independent observer unaware of the experimental conditions $(0=0-2$ cells; $1=3-6$ cells; $3=7-10$ cells; $4=>10$ cells per field). Positive cells were counted in four representative fields by high-power field magnification $(\times 200)$.

Airway wall thickening was determined using standard morphometric technique on $\alpha$-SMA-stained paraffin section cult from the upper part of the left lung. Conducting airways (width $>190 \mu \mathrm{m}$ ) were captured at $\times 20$ with a digital camera and the smooth muscle cell area surrounding the airways was quantified by computerized morphometry using the Quantimet $570 \mathrm{C}$ imaging analysis system (Leica Microsystems, Cambridge, UK). Increased width of the smooth muscle layer was taken as evidence of airway wall thickening.

Standard morphometric technique was used to determine the presence of emphysematous changes in the lungs. In brief, H\&E-stained paraffin sections cut from the upper part of the left lung were used, and 10 randomly selected fields were sampled by projecting a microscopic image of the lung section on a screen with a square reference lattice containing one horizontally and one vertically placed test line. The number of intersections of alveolar walls on the test lines 
were quantified by computerized morphometry using the Quantimet $570 \mathrm{C}$ imaging analysis system (Leica Microsystems) and used to quantify alveolar mean linear intercept ( $L_{M}$, the average distance between alveolar walls). Increased $L_{i m}$ was taken as evidence of alveolar enlargement.

\section{Reverse transcription-polymerase chain reaction}

Total RNA was isolated from snap frozen lung tissue of the right lung using a commercially available kit (SV Total RNA Isolation System; Promega, Madison, WI). Total RNA concentration and purity was ascertained by electrophoresis on an ethidium bromide-stained $0.8 \%$ agarose gel followed by UV illumination and UV spectrophotometric analysis at wavelengths of 260 and $280 \mathrm{~nm}$. Five micrograms of total RNA was reverse transcribed in a $20 \mu \mathrm{l}$ volume using olligo (dT) primers and Moloney murine leukemia virus reverse transcriptase (M-MLVRT; Life Technologies, Paisley, UK) according to the supplier's recommendations. PCR was performed in a $25 \mu \mathrm{l}$ reaction volume containing $100 \mu \mathrm{M}$ of each dNTP, $200 \mathrm{nM}$ sequence-specific primers, and $0.5 \cup \mathrm{Taq}$ DNA polymerase (Perkin Elmer/Cetus) during $35-40$ cycles under the following conditions: $95^{\circ} \mathrm{C} 30 \mathrm{~min}$, annealing temperature (AT) $45 \mathrm{~min}, 72^{\circ} \mathrm{C} 30 \mathrm{~min}$. PCR primers used in RT-PCR for interleukin (IL)-6 $\left(318 \mathrm{bp}\right.$, AT $\left.56^{\circ} \mathrm{C}\right)$ were sense primer $\left(5^{i}\right.$-TGG GAAATCGTGGAAATGAGA-3') and antisense primer (5'-GAGAGCATTGGAAATा GGGGT-3'), whereas PCR primers for tumor necrosis factor (TNF)- $\alpha$ (307 bp, AT $63^{\circ} \mathrm{C}$ ), interferon (IFN)- $\gamma\left(243 \mathrm{bp}\right.$, AT $\left.63^{\circ} \mathrm{C}\right), 1 \mathrm{~L}-18\left(582 \mathrm{bp}\right.$, AT $\left.63^{\circ} \mathrm{C}\right)$, and B-actin $\left(348\right.$ bp, AT $\left.60^{\circ} \mathrm{C}\right)$ were designed as previously described ${ }^{16,17}$. A mock PCR (without CDNA) was included to exclude contamination. CDNA samples were standardized based on the content of B-actin CDNA as housekeeping gene. B-Actin CDNA was evaluated by performance of a $B$-actin PCR on multiple dilutions of each CDNA sample. The amount of amplified product was estimated by densitometry of gelstar (FMC Bioproducts, Rockland, ME) stained 1.2\% agarose gels using a CCD camera and Imagemaster VDS software (Pharmacia). Relative mRNA levels for TNF- $\alpha$, IL- 6 , IFN- $\gamma$, and IL-18 were calculated by comparison of band intensities of the RT-PCR products to standard curves prepared by PCR amplifications on dilution series of a highly concentrated murine lung CDNA.

\section{Statistical analysis}

Statistical analysis was performed by means of one-way ANOVA, and the MannWhitney $U$ test was used as post hoc test (Statistical Package for the Social Sciences, version 7.5 for Windows; SPSS Inc, Chicago, IL). Data are expressed as mean \pm standard error of the mean (SEM). A P value $<0.05$ denotes the presence of a significant statistical difference.

\section{RESULTS}

Persistent chronic pulmonary inflammation after long-term LPS exposure Histological examination of H\&E-stained lung tissue sections of mice repeatedly 

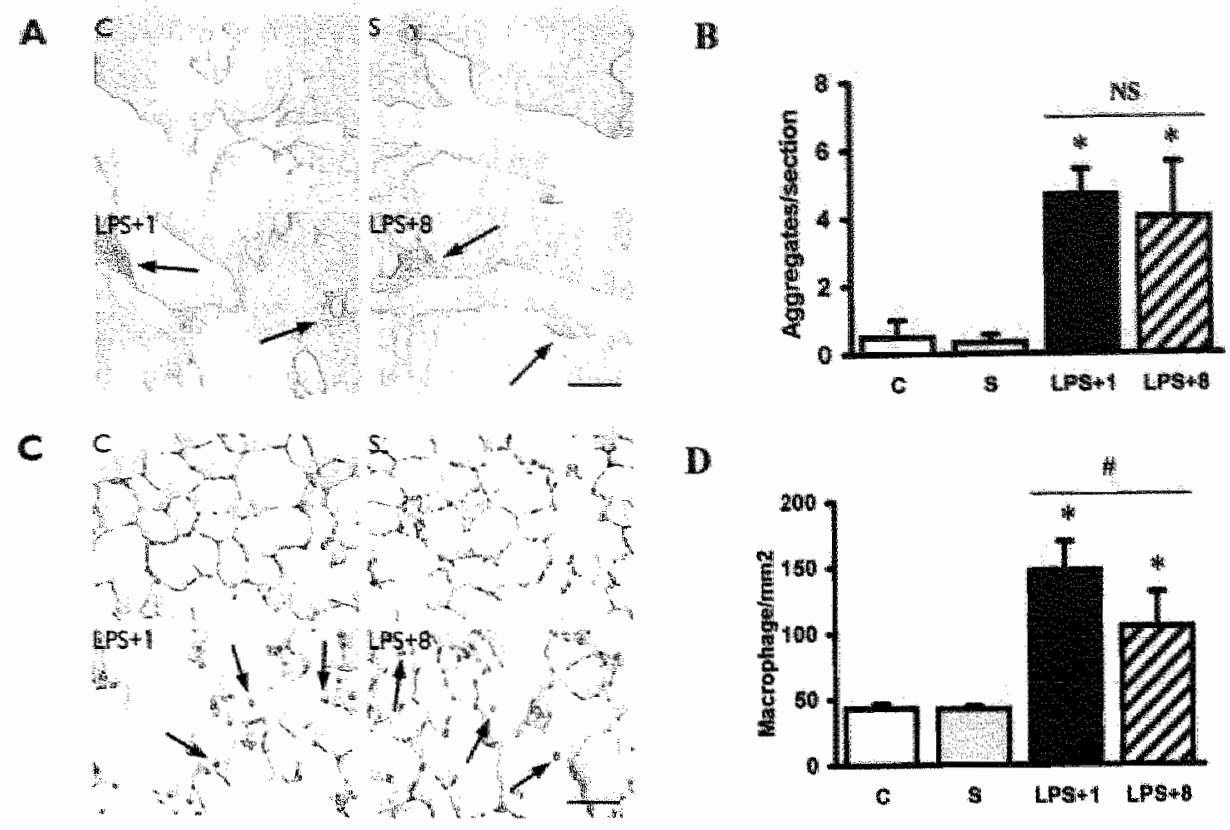

Figure 1. Persistent pulmonary inflammation induced by fong-term intratracheal LPS instillation. Mice were repeatedly instilled with 5 Mg LPS for 12 weeks, and killed 1 wk [LPS+1] or 8 wk [LPS +8 ] after the final intratracheal instillation. Age-matched control mice were repeated exposed to saline $[S]$ for 12 wk or not treated $[C]$. (A) H\&E staining of paraffin sections demonstrated persistent peribronchial and perivascular lymphocytic infiltrates (arrows) in LPS-challenged mice and the lack of these inflammattory patterns in control mice. Bar $=200 \mu \mathrm{m}$. (B) Quantification of iymphocytic aggregates, expressed as aggregates/section (mean $\pm \mathrm{SEM}, \mathrm{n}=5$ to $10 \mathrm{mice} / \mathrm{groupl}$. $* \mathrm{P}<0.05$ werstis control: NS, not significant. (O) Higher-power view of H\&E-stained paraffin section demonstrating accumulation of macrophages (arrows) in parenchyma of $L P S$-treated mice. Bar $=50 \mu \mathrm{m}$. (D) Quantitative distribution of intra-alveolar macrophages, expressed as macrophages $/ \mathrm{mm}^{2}$ (mean $\pm S E M, n=5$ mice/group). * $P<0.05$ versus control; \# $P<0.05$ versus $L P S+1$.

exposed to LPS (5 $\mu \mathrm{g} /$ mouse) twice/wk for $12 \mathrm{wk}$ demonstrated a striking inflammatory pattern after a 1 -wk recovery period. First, lungs of LPS-challenged mice contained dense lymphocytic aggregates, which were observed ubiquitously in all parts of the lungs (Figures $1 \mathrm{~A}$ and $1 \mathrm{~B}$ ). As illustrated in Figure 1A, aggregates appeared to be located around the airways (peribronchial and peribronchiolar) and large vessels (perivascular), usually without affecting the ciliated bronchial epithelial cells. Incidentally, lymphocytic cells infiltrated the bronchial epithelial layer, resulting in local bronchiolitis (data not shown). These lymphocytic aggregates or infiltrates were not noted in lungs of saline-treated and age-matched control animals. Second, a profound intra-alveolar accumulation of mononuclear leukocytes was clearly noticeable in parenchyma of LPS-exposed mice, which consisted predominantly of macrophages (Figures 1C and 1D). These inflammatory changes were not observed in the parenchyma of saline-treated and age-matched control mice. Interestingly, pulmonary infiltration of neutrophils observed to occur rapidly after each LPS exposure (data not shown) was not observed after 1 -wk recovery period, indicating that acute inflammatory changes 
were resolved at this time point. To study if LPS-induced pulmonary inflammation is an ongoing process, mice were killed 8 wk after cessation of LPS challenge. Histologic examination demonstrated that lymphocytic aggregates observed at 1 wk after the final LPS exposure were still present after this long recovery period, and appeared to be of similar size and density (Figure 1A-B), suggesting persistence of the inflammatory reaction. Furthermore, parenchymal tissue of LPSexposed mice showed a significant increase of macrophages at this time point when compared with control mice (Figures $1 \mathrm{C}$ and $1 \mathrm{D}$ ). However, macrophage numbers tended to be slightly but significantly reduced when compared with LPStreated animals after 1 -wk recovery period. Taken together, these data demonstrate that repeated intratracheal instillations of LPS result in a persistent chronic pulmonary inflammatory response, characterized by lymphocytic aggregates around airways and vessels and parenchymal accumulation of mononuclear leukocytes.

\section{Characterization of cellular infiltrates}

The specific nature of cellular infiltrates in airways and parenchyma was further characterized by immunohistochemistry on frozen lung sections. To this end, a panel of monoclonal antibodies against murine T lymphocytes (CD4+ or CD8+), B lymphocytes, macrophages, and neutrophils was used. As shown in Figure 2A,

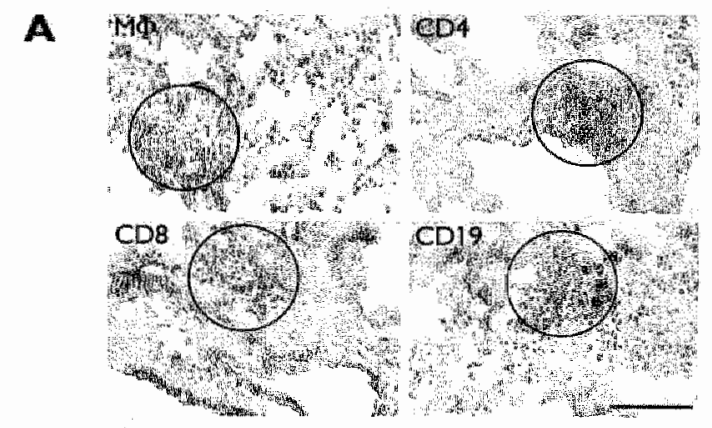

B

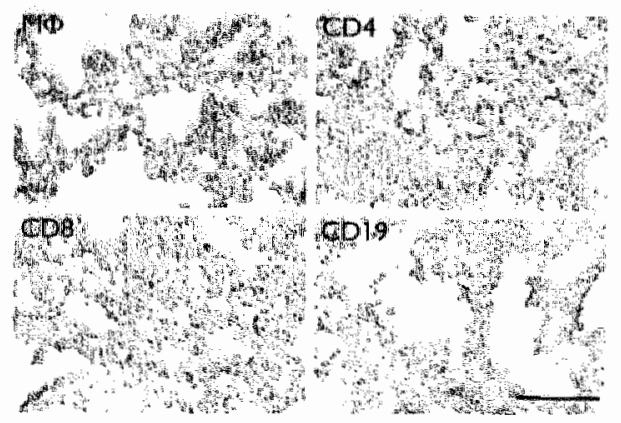

C
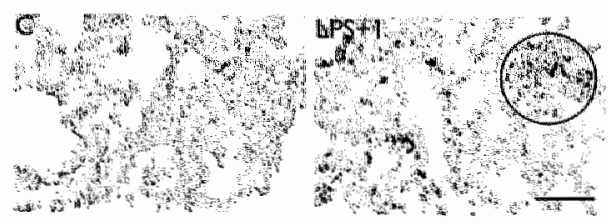

Figure 2. Characterization of cellular infittrates in LPS-challenged mice. Frozen lung sections of LPS-challenged mice after 1 -wh recovery period were evaluated by immunohistochemistry using mabs for macrophages (Md), T Iymphocytes (CD4 \# or CD8+), and B lymphocytes (CD19+) (A) Composition of lymphocytic aggregates (circle). Note the presence of lymphocyles (CD4t, CD8t, and $\mathrm{CD1} 9+1$, and absence of macrophages in these aggremates. (B) Cellular infiltrates in parenchyma. Note the accumulation of macrophages and $\mathrm{CD} 8+\mathrm{T}$ cells bn the parenchymal area. (C) Expression of $M H C$ class $\| 1$ antigen. Note the low staining for MHC $\|$ in control animals $1 \mathrm{Cl}$, and the intense staining for $\mathrm{MHC} \|$ in in intraalveotar mononuclear leukocytes as well as Iymphocytic cells in the aggregattes (circle) in LPS-treated animals after 1-wk recovery period [LPS+1]. Bar = 50 fm. Results are representative for three separate experiments. 
Table 1. Lymphocyte subsets in lungs of LPS-challenged mice and controls*

\begin{tabular}{lccccc}
\hline Score & $\begin{array}{c}\text { Control } \\
(n=5)\end{array}$ & $\begin{array}{c}\text { Saline } \\
(n=5)\end{array}$ & $\begin{array}{c}\text { LPS }+1 \\
(n=5)\end{array}$ & $\begin{array}{c}\text { LPS }+8 \\
(n=4)\end{array}$ & p Value \\
\hline CD & $0.60 \pm 0.24$ & $0.60 \pm 0.40$ & $0.80 \pm 0.37$ & $0.75 \pm 0.48$ & NS \\
CD8 & $0.40 \pm 0.24$ & $0.60 \pm 0.24$ & $2.00 \pm 0.45^{\prime}$ & $2.25 \pm 0.48$ & $<0.01$ \\
CD20 & $0.40 \pm 0.24$ & $0.40 \pm 0.40$ & $0.60 \pm 0.40$ & $0.75 \pm 0.48$ & NS
\end{tabular}

* Data are expressed as mean $\pm S E M ; N S=$ not significant; 'Significant versus saline-treated and control animals.

immunohistochemical staining identified $C D 4+T$ lymphocytes as the principal component of the aggregates present in lungs of LPS-exposed mice after a short recovery period. Other mononuclear cells included CD8+ T lymphocytes and B lymphocytes, which were present to lesser extent at the periphery of these aggregates. Thorough examination of serial sections revealed that aggregates were not organized in $T$ cell and B cell zones, thus lacking any resemblance with lymph nodes or bronchus-associated lymphoid tissue (BALT). In addition, neither neutrophils nor macrophages were noted in these aggregates. As shown in Figure $2 \mathrm{~B}$, immunohistochemical staining confirmed the prominent accumulation of macrophages as well as the absence of infiltrated neutrophils in the parenchyma of LPS-challenged mice. In addition, positive staining for lymphocytes was observed in the alveolar area of mice repeatedly exposed to LPS; this was not clearly noticeable in H\&E-stained paraffin sections. Interestingly, the number of $\mathrm{CD} 8+T$ cells, but not CD4 $+\mathrm{T}$ cells and CD19+ B cells, in the parenchyma was significantly increased relative to controls (Table 1). Furthermore, evaluation lungs from LPS-exposed mice killed after an 8-wk recovery period demonstrated that cessation of LPS challenge did not result in an altered composition of the lymphocytic aggregates and the inflammatory pattern in the parenchyma (Table 1). Additionally, we analyzed MHC class II antigen expression, which is considered to be a marker for cell activation that correlates with the intensity of the immune response ${ }^{18}$. As shown in Figure $2 \mathrm{C}$, low staining for MHC II was noted in alveolar macrophages from control animals. In LPS-challenged animals, mononuclear leukocytes present in the parenchyma as well as lymphocytic cells located in the aggregates displayed positive staining for MHC II after 1-wk (Figure 2C) and 8-wk (data not shown) recovery periods. The staining intensity was strongly increased in LPS-challenged mice when compared with controls, indicating that infiltrated inflammatory cells in both airway and parenchymal regions were activated. Taken together, these data demonstrated $\mathrm{CD} 4+\mathrm{T}$ cells to be the principal component of peribronchial and perivascular lymphocytic aggregates observed after 1 -wk and 8 -wk recovery periods, whereas macrophages and CD8+ T cells were identified to accumulate in the parenchymal area of LPSexposed mice. Furthermore, infiltrated inflammatory cells were activated in respect of $\mathrm{MHC}$ II expression.

\section{Cytokine mRNA expression}

Because the chronic character of an inflammatory response is possibly due to 
alteration in expression levels of Th1 cytokines ${ }^{19-29}$, we investigated mRNA levels of the Th1 type cytokines TNF- $\alpha$, IL-6, and IFN- $\gamma$ in lungs of LPS-exposed mice and controls using RT-PCR. Additionally, IL-18 mRNA levels were determined, which is. known to be involved in IFN- $\gamma$ expression and to be associated with chronic inflammation. After correction for B-actin levels, lungs of LPS-exposed mice demonstrated enhanced mRNA expression for TNF- $\alpha$, IFN- $\gamma$, and IL-18, whereas these mRNA levels were low or negligible in saline-exposed and noninstilled lungs (Figure 3A). Remarkably, expression levels for all three cytokines further increased after $8 \mathrm{wk}$ when compared with levels after a 1 -wk recovery period. In contrast, lungs of saline-exposed and control mice demonstrated constitutive mRNA levels for IL-6, but these levels were not increased after long-term LPS exposure. These observations were confirmed by the calculation of the densitometric ratio for each mRNA expression (Figure $3 B$ ).

A

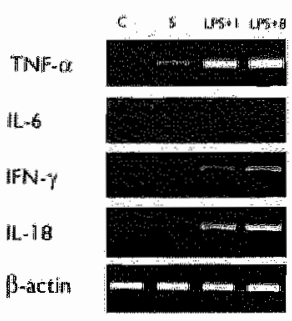

B

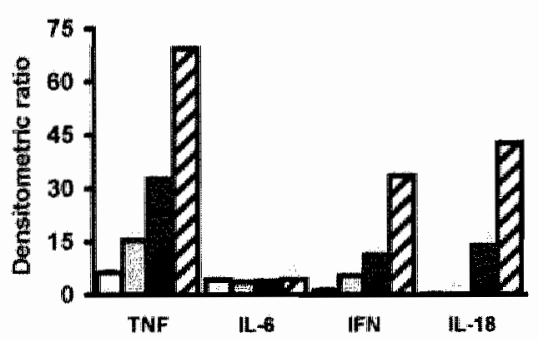

Figure 3. Transcription of inflammatory mediators in murine lung tissue as determined by RT-PCR. Total RNA was isolated from lung tissue of age-matched control mice $[\mathrm{Cl}$, saline-ureated mice $[S]$, and $L P S$-challenged mice after $1-w k[L P S+1]$ and $8-w k$ [LPS + 81 recovery period (A) InRNA expression levels of TNF- $\alpha$ (307 bp), LL-6 (318

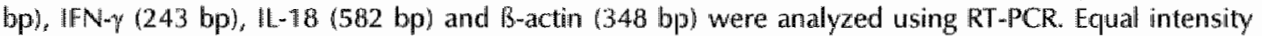
of B-actin mRNA bands confirmed equal loading of CDNA in RT-PCR. One representative experiment from a series of three is shown. (B) Densitometric ratio's ( $n=3$ mice/group).

\section{Airway and alveolar alterations after long-term LPS exposure}

Lungs of LPS-challenged mice demonstrated a variety of abnormalities in airways and parenchyma. First, lung sections stained with PAS/Alcian blue showed a marked increase of mucus producing cells numbers after a 1-wk recovery period, compared with saline-treated controls (Figure 4A). Metaplasia of airway goblet cell was evident in the larger airways of the respiratory tract, especially at sites where lymphocytic infiltrates were underlying the bronchial epithelium. Secretory cell metaplasia was also observed 8 wk after cessation of LPS challenge, but to a lesser extent, suggesting that these metaplastic events may be reversible. Second, airway walls of LPS-exposed mice were thickened when compared with controls. Immunohistochemical staining indicated the presence of $\alpha$-SMA in small, elongated cells arranged circumferentially in a single layer in the airway submucosa of control mice. On the other hand, airways of LPS-challenged mice were characterized by a patchy $\alpha$-SMA staining, and commonly of two layers of nuclei in the airway submucosa. As shown in Figure 4B, width of the smooth muscle layer was significantly increased after both 1-wk and 8-wk recovery periods compared with controls. Alveolar alterations were examined by morphometric measurements of alveolar enlargement and evaluation of 
proliferation. Morphometric evaluation of alveolar dimensions revealed emphysematous changes in LPS-challenged mice at 1-wk recovery period (Figures $4 C$ and $4 D$ ). In contrast, repeated saline exposure did not result in alveolar enlargement when compared with controls. Importantly, lungs from LPS-exposed mice sacrificed after an 8-wk recovery period still displayed emphysematous changes, indicating permanent enlargement induced by long-term LPS exposure. Furthermore, the expression of Ki-67 antigen, a marker of active cell proliferation, was evaluated to investigate presence of repair processes. Alveolar epithelial cells of LPS-exposed mice did not display Ki-67 staining, neither after 1-wk nor after 8wk recovery periods (data not shown), indicating the absence of active repair processes. Taken together, these data show that long-term LPS exposure results in pathologic changes in airways and parenchyma, characterized by goblet cell metaplasia and airway wall thickening, and irreversible alveolar enlargement.

A s
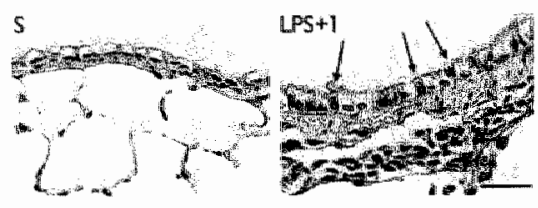

B

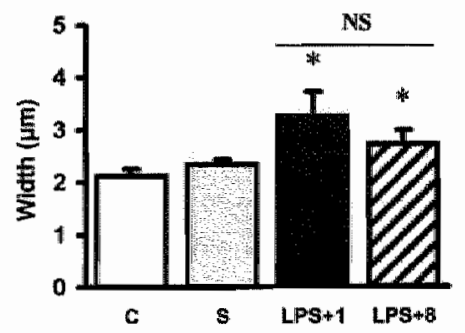

C

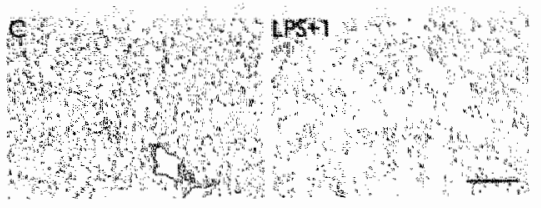

D

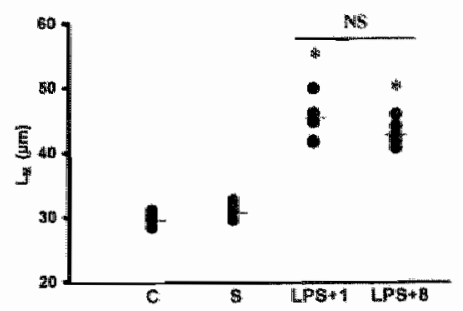

Fingure 4. Airway and alveolar abnormalities after longuterm intratracheal LPS instillation. (A) Mucus cell metaplasia. Representative lung histology (PAS/Alcain blue staining) of mice repeatedly exposed to saline [S] or LPS after 1-wk recovery period [LPS +1 ]. Note the mucus producing bronchial epithelial cells in L.PS-challenged mice (arrows). Bar $=25 \mu \mathrm{mm}$. (B) Morphometric analysis of ainway wall thickening. Paraffin sections were stained for $\alpha$-SMA, and widh of smooth muscle layer is expressed in $\mu \mathrm{m}$. * $\mathrm{P}<0.05$ versus control; NS, not significant. $(C)$ Alveolar entargement. H\&E staining of paraffin sections demonstirated destruction of alveolar walls in LPS-instilled mice after 1 -wk recovery period [LPS+1] compared to control mice [C]. Bar $=100 \mu \mathrm{m}$. (D) Morphometric analysis of alveolar enlargement. Alveolar mean linear intercept $\left(L_{A}\right)$ values are expressed in $\mu \mathrm{m}$ (mean $1 \mathrm{sEM}, n=5$ mice/group). ${ }^{*} P<0.05$ versus control; NS not. significant.

\section{DISCUSSION}

This study investigated inflammatory and pathologic alterations after long-term LPS exposure to the lung. Mice were repeatedly exposed to LPS and killed after 1wk or 8 -wk recovery periods. We have previously demonstrated that single intratracheal LPS challenge results in rapid but transient infiltration of neutrophils 
from the pulmonary vascular bed into the respiratory air spaces" associated with acute lung injury, such as increased pulmonary vascular permeability and pulmonary edema. The present study is the first to characterize chronic inflammatory events induced by repeated intratracheal LPS instillation. We demonstrate that long-term intratracheal LPS exposure resulted in a persistent chronic inflammatory reaction, which is accompanied by alterations in airways and parenchyma.

Lungs of LPS-challenged mice contained dense peribronchial and perivascular lymphocytic aggregates, which did not appear to be organized in lymphoid follicles. In addition, aggregates were shown to consist of mainly $T$ lymphocytes and less B lymphocytes (no macrophages) supporting the observation that these lymphocytic aggregates show no similarity with normal lymph nodes or BALT present in the murine lung ${ }^{22}$. Origin of these aggregates is uncertain, but they may originate from small $T$ and $B$ cell clusters that have been described in the murine lung in the vicinity of bronchioles and veins ${ }^{22}$. Interestingly, this type of mononuclear inflammatory cell accumulation in the peribronchial area was also noted in transgenic mice overexpressing specific proinflammatory cytokines in the airway epithelial cells ${ }^{20,23,24}$. Especially peribronchial infiltrates in human IL-6 transgenic mice show striking similarity to our observations, e.g., significant numbers of $\mathrm{CD} 4+$ and $\mathrm{CD} 8+\mathrm{T}$ lymphocytes and $\mathrm{B}$ lymphocytes, but lacking alveolar macrophages ${ }^{20}$.

Long-term LPS exposure also resulted in a chronic inflammatory response in the parenchymal area, which was comprised of activated macrophages indicated by increased expression of MHC class II molecules on the cell surface and CD8+ $T$ cells. The absence of neutrophils at $1 \mathrm{wk}$ after the last LPS exposure indicates that neutrophil infiltration is rather a transient process triggered by each LPS exposure instead of being a chronic factor. Recently, Ofulue and colleagues demonstrated that long-term exposure (up to $6 \mathrm{mo}$ ) to cigarette smoke in rats resulted in a similar increase of intra-alveolar macrophages ${ }^{25}$. This result is in accordance with our observations, assuming that LPS is an important contaminant of cigarette smoke.

An interesting result of the present study is that the characteristic inflammatory pattern in the lung induced by repeated intratracheal LPS instillation continued after cessation of the LPS challenge, which supports the important role for LPS in chronic lung inflammation. Studies using transgenic mice ${ }^{1 y-21}$ suggest that altered expression levels of Th1-type cytokines like TNF- $\alpha$, IL- 6 , and IFN- $\gamma$ may contribute to the ongoing inflammatory response and structural changes in airways and parenchyma. We therefore investigated mRNA levels of these specific Th1-type cytokines in lungs of LPS-exposed mice, and also mRNA levels of IL-18, which is involved in IFN- $\gamma$ expression and has been associated with chronic inflammation. The inflammatory response in the LPS-treated animals was characterized by significant increases in mRNA levels for TNF- $\alpha, \mathrm{IL}-18$, and IFN- $\gamma$, which further increased after cessation of LPS challenge. These data support the idea that ongoing inflammatory processes induced by long-term LPS exposure results from an altered cytokine balance, involving cytokines derived from both macrophages 
and lymphocytes. Interestingly, long-term LPS exposure did not influence the constitutive mRNA levels for IL-6 in saline-exposed and control lungs. This was unexpected, since the pattern of pulmonary inflammation in $\mathrm{LL}-6$ transgenic mice showed striking similarities with our observations ${ }^{20}$. However, IL-6 is documented to be a downregulator of LPS-induced TNF- $\alpha$ and IL-1B expression in vitro and a strong inhibitor of LPS-induced acute inflammation in rats ${ }^{26,27}$. We speculate that the lack of IL-6 upregulation in lungs of mice repeatedly exposed to LPS may contribute to an altered cytokine balance. The exact mechanism by which long. term LPS exposure alters the cytokine balance, however, is unclear and awaits further investigation.

In addition to the persistent inflammatory events, long-term LPS exposure resulted in significant airway and alveolar abnormalities. First, bronchial epithelium of LPS-challenged mice displayed an increase in the mucus-producing goblet cells in the larger airways, especially at sites where lymphocytic infiltrates were underlying the bronchial epithelium. Because only small numbers of goblet cells are present in murine airways, this increase is likely due to cell differentiation (metaplasia) rather than cell division (hyperplasia). In line with our findings, increase of airway mucus cells was reported after single intratracheal LPS instillation in mice $^{23}$, and repeated intratracheal LPS exposure in rats ${ }^{29}$ and hamsters $^{30}$. Whether the mucus cell metaplasia observed by histologic analysis also involves increased expression of mucin genes obviously needs further study. Second, airways of LPS-challenged mice demonstrated thickening of the smooth muscle layer. Recently, George and colleagues ${ }^{31}$ demonstrated similar airway wall thickening with patchy actin staining after long-term exposure to corn dust extract in mice, which is known to contain high levels of LPS. In addition, increased bronchial wall thickness was also demonstrated in transgenic mice overexpressing IL-6 or IL-11 in airway epithelial cells ${ }^{32}$. Third, long-term intratracheal LPS exposure resulted in alveolar enlargement without any signs of proliferation of alveolar epithelial cells, which was shown to be irreversible. Consistent with our data, previous reports described approximately equal extent of parenchymal destruction in the lungs of hamster ${ }^{30,33}$ and mice ${ }^{34}$ after repeated LPS challenge using different instillation protocols, and after long-term exposure to cigarette smoke ${ }^{25,35}$. However, lungs of transgenic mice overexpressing specific proinflammatory cytokines inducible or not in alveolar type II cells (TNF- $\alpha^{14}$ ) or airway epithelial cells (IFN- $\gamma^{21}$, IL-6, or $\mid \mathrm{L}-11^{32}$ ) displayed enormous alveolar destruction $\left(L_{M}>100 \%\right)$.

The pathologic changes we observed in both airways and parenchyma after multiple LPS challenge in mice mimic important features observed in COPD patients, such as goblet cell metaplasia, airway wall thickening, and emphysematous changes. Recent histopathologic studies have demonstrated a prominent infiltration of macrophages and CD8 + lymphocytes in bronchial tissue and lung parenchyma in COPD ${ }^{36}$, both of which we also observed in the lungs of mice after long-term LPS exposure. Additionally, neutrophil infiltration is shown particularly in the central airways of COPD patients ${ }^{37}$. The fact that we focused on peripheral airways and parenchyma of LPS-exposed mice may therefore explain 
the lack of neutrophils as a chronic factor in our model. Increasing evidence emerges that both macrophages and neutrophils have an important role in the proteolytic degradation of the extracellular matrix in COPD by production of matrix metalloproteinases. The role of $\mathrm{CD} 8+T$ cells and their mediators in this process is, however, still uncertain but very intriguing as they may be involved in apoptosis and destruction of alveolat-wall epithelial cells through the release of TNF- $\alpha$, perforins, and granzymes ${ }^{37}$.

Pulmonary burden with various reagents may potentially result in a response by the respiratory system. Concerning LPS exposure, numerous studies demonstrated that chronic exposure to significant levels of LPS in man is associated with the development and/or progression of many types of chronic inflammatory lung diseases, including asthma, chronic bronchitis, and progressive irreversible airflow obstruction. Additionally, this study showed that long-term LPS exposure in mice induces a chronic mononuclear inflammatory response with specific pathologic changes mimicking COPD. Because the major environmental factor that predisposes patients to COPD is long-term cigarette smoking we speculate that LPS present in cigarette smoke is a good candidate to trigger smoking-induced accumulation of macrophages, lymphocytes, and neutrophils in respiratory bronchioles, alveolar ducts, and alveoli in susceptible cigarette smokers. We consider this experimental murine model an important means for further elucidation of the role of chronic inflammation in the pathogenesis of chronic pulmonary disorders like COPD.

\section{ACKNOWLEDGEMENTS}

We thank Dr. Esther Koerts-de Lang and Niki Reynaert for their expert technical assistance. This work was supported by Glaxo Wellcome, The Netherlands.

\section{REFERENCES}

1. Kline JW, Cowden JD, Hunninghake CW, schutte BC, Watt IL, Wohlford lenane CL, Powers $L S$, Jones MP, and Schwartz DA. Variable airway responsiveness to inhaled lipopolysaccharide. Am J Respivi Crit Cane Med 1999;160:297-303.

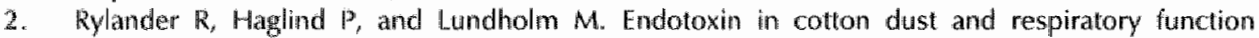
decrement among cotton workers in an experimental cardroom. Am Rev Respir Dis $1985,131: 209.213$

3. Del A, Godshall MA, and Palmgren MS. Gram-negative bacterial endotoxins in grain elevator dusts. Am Ind Hyg Assoc/ $1984 ; 45: 336-339$.

4. Hasday JD, Bascom $R$, Costa Jl, Fitzgerald $T$, and Dubin W. Bacterial endotoxin is an active component of cigarette smoke. Chest 1999;115;829-835.

5. Hartung $]$, and Seedorf $]$. Orienting endotoxin measurement in the atmosphere. DTW Dtsch Tieratzel Wochenschr 1999:106:522-525.

6. Michel O, Buchateau 1. Plat C, Cantinieaux B, Hotimsky A, Gerain 1, and Sergysels R. Blood inflammatory response to iwhaled endotoxin in normal subjects. Clin Exp Allergy 1995;25:73-79.

7. Jagielo Pl, Thome PS, Watt $\mathrm{L}_{*}$ Frees $\mathrm{KL}$, Quinm T), and Schwartz. DA. Grain dust and endotoxin inhalation challenges produce similar inflammatory responses in nomal subjects. Chest $1996 ; 110: 263-270$. 


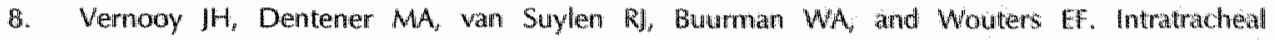
Instillation of Lipopolysaccharide in Mice Induces Apoptosis in Bronchial Epithelial Cells. No role for tumor necrosis factor-alpha and infiltrating neutrophils. Am / Respir Cell Mol Biol $2001 ; 24: 569-576$.

9. Michel $O$, Duchateau $J$, and Sergysels $R$. Effect of inhaled endotoxin on bronchial reactivity in asthmatic and normal subjects. / Appl Physiol 1989;66:1059-1064.

10. Michel $O$, Kips J, Duchateau J, Vertongen $F$, Robert L, Collet $H$, Pauwels $R$, and Sergysels R. Severity of asthma is related to endotoxin in house dust. Am / Respir Crit Care Med $1996 ; 154: 1641-1646$.

11. Cavagna $G$, Foa $W$, and Vigliani EC. Effects in man and rabbits of inhallation of cotton dust or extracts and purified endotoxins. $\mathrm{Br}$ / Ind $\mathrm{Med} 1969 ; 26: 314-321$.

12. Smid $T$, Heederik $D$, Houba $R$, and Quanjer PH. Dust- and endotoxin-related acute lung function changes and work-related symptoms in workers in the animal feed industry. Am I Ind Med $1994 ; 25: 877-888$.

13. Schwartz DA, Thorne PS, Yagla SI, Burmeister $L F$, Olenchock $S A$, Watt $J L$, and Quinn T]. The role of endotoxin in grain dust-induced lung disease. Am / Respir Crit Care Med 1995;152:603-606.

14. Vogelzang PF, van der Gulden JW, Folgering $\mathrm{H}$, Kolk IJ, Heederik D, Preller $\mathrm{L}$, Tielen MI, and van Schayck CP. Endotoxin exposure as a major determinant of lung function decline in pig tarmers. Am I Respir Crit Care Med' 1998;157:15-18.

15. Lutgens $E$, Daemen $M$, Kockx $M$, Doevendans $P$, Hofker $M$, Havekes $L$, Wellens $H$, and de Muinck $\mathrm{ED}$. Atherosclerosis in APOE*3-Leiden transgenic mice: from proliferative to atheromatous stage. Circulation 1999;99:276-283.

16. Daemen MA, van de Ven MW, Heineman $E$, and Buurman WA. Involvement of endogenous interleukin-10 and tumor necrosis factor-alpha in renal ischemia-reperfusion injury. Transplantation 1999;67:792-800.

17. Daemen MA, want Veer $C$, Wolfs $T \mathrm{TC}_{\mathrm{w}}$ and Burman WA. Ischemia/reperfusion-induced IFNgamma up-regulation: involvement of IL-12 and IL-18. / Immuno/ 1999;162:5506-5510.

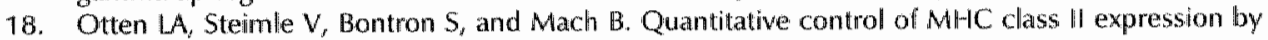
the transactivator CITA. Eur / Immunol 1998;28:473-478.

19. Fujita $M$, Shannon $\mathrm{JM}_{t}$ Irvin $C G$, Fagan $K A$, Cool $C_{r}$ Augustin $A_{f}$ and Mason RJ. Overexpression of tumor necrosis factor-alpha produces an increase in lung volumes and pulmonary hypertension. Am I Physiol Lung Cell Mol Physiol 2001, 280:L39-49.

20. DiCosmo BF, Geba GP, Picarella D, Elias JA, Rankin JA, Stripp BR, Whitsett JA and Flawell RA. Airway epithelial cell expression of interleukin- 6 in transgenic mice. Uncoupling of airway inflammation and bronchial hyperreactivity. J Clin Invest 1994,94:2028-2035.

21. Wang $Z$, Zheng $T$, Zhu $Z$, Homer RJ, Riese RJ, Chapman HA, Jr., Shapiro SD, and Elias JA. Interferon gamma induction of pulmonary emphysema in the adult murine lung. I Exp Med $2000 ; 192: 1587-1600$.

22. Kolopp Sarda MN, Bene MC, Massin N, Moulin II, and Faure GC. Immunohistological analysis of macrophages, B-cells, and T-cells in the mouse lung. Anat Rec 1994:239:150-157.

23. Temann UA, Geba GP, Rankin JA, and Flavell RA. Expression of interleukin 9 in the lungs of transgenic mice causes airway inflammation, mast cell hyperplasia, and bronchial hyperresponsiveness. J Exp Med 1998;188:1307*1320.

24. Tang W, Ceba CP, Zheng T, Ray P, Homer RJ, Kuhn C, 3rd, Havell RA, and Elias JA, Targeted expression of $1 \mathrm{~L}-11$ in the murine airway causes lymphocytic inflammation, bronchial remodeling, and airways obstruction. J Clin Invest 1996;98:2845-2853.

25. Ofullue AF, Ko $M$, and Abboud RT. Time course of neutrophil and macrophage elastinolytic activities in cigarette smoke-induced emphysena. Am / Physiol 1998;275:L1134-1144.

26. Schindler $R$, Mancilla), Endres $S$, Ghorbani $R$, Clark $S C$, and Dinarello CA. Correlations and interactions in the production of interleukin-6 ( $\| L-6), \| L-1$, and tumor necrosis factor (TNF) in human blood moromuclear cells: IL-6 suppresses IL-1 and TNF. Blood 1990;75;40-47.

27. Ulich $T R$, Yin $S$, Cuo $K, Y_{i} E S$, Remick D, and del Castillof. Intratracheal injection of endotaxin and cytokines. 11 . Interleukin -6 and transforming growth factor beta inhibit acute inflammation. An I Pathol 1991:138:1097*1101.

28. Vanagihara $K_{\text {, Seki }} \mathrm{M}_{\text {, }}$ and Cheng PW. Lipopolysaccharide Induces Mucus Cell Metaplasia in Mouse Lung. Am J Respir Cell Mol Biol 2001;24:66-73. 
29. Harkema JR, and Hotchkiss JA. Ozone and endowininduced mucous cell metaplasias in rat dirway epithelium: novel animal models to study toxicant-induced epithellal transformation in ainways. Toxicol Let $1993,68: 251-263$.

30. Stolk 1, Rudolphus $A$, Davies P, Osinga D, Dijkman IH, Aganwall L, Keenan KP, Fletcher D, and kramps IA Induction of emphysema and bronchial mucus cell hyperplasia by intratracheal instillation of lipopolysaccharide in the hamster. / Pathol 1992:167:349-356.

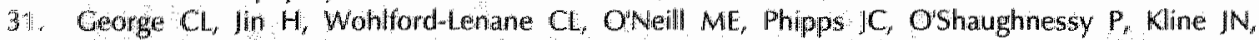
Thorne PS, and Schwartz DA. Endotoxin responsiveness and subchronic grain dust-induced aiway disease. Am If Physiol Lung Cell Mol Physiol 2001;280:1203-213.

32. Kuhn $C$, $3 r d$, Homer $R$ I, Zhu $Z$, Ward $N$, Flavelf RA, Geba GP, and Elias JA. Ainway hyperresponsiveness and airway obstruction in transgenic mice. Morphologic correlates in mice overexpressing interleukin (IL) 11 and IL-6 in the lung. Am / Respir Cell Mol Biol 2000;22:289295.

33. Milton DK, Godleski JI, Feldman HA, and Greaves IA. Toxicity of intratracheally instilled cotton dust, cellulose, and endotoxin. Am Rev Respir Dis 1990;142:104-192.

34. Starcher $B$ and Williams 1 . The beige mouse: role of neutrophil elastase in the development of pulmonäry emphysema. Exp Lung Res 1989;15:785-800.

35. Hautamaki RD, Kobayashi DK, Senior RM, and Shapiro SD. Recuirement for macrophage elastase for cigarette smoke-induced emphysema in mice. Science 1997;277:2002-2004.

36. Saetta $M$, Baraldo $S$, Corbino $L$, Turato $G$, Braccioni $F$, Rea $F$, Cavallesco $G$, Tropeano $G$, Mapp $C E$, Maestrelli $P$, Ciaccia $A$, and Fabbri LM. CDB+ve cells in the lungs of smokers with chronic obstructive pulmonary disease. Am / Respir Crit Care Med 1999:160:711-717.

37. Barnes P. Chronic obstructive pulmonary disease. N Engl J Med 2000;343:269-280. 


\section{CHAPTER 10}

\section{Discussion and future directions}

\section{INTRODUCTION}

According to the ATS statement in 1995', COPD is characterized by the presence of airflow limitation that is generally progressive and not fully reversible. This physiological definition of COPD has definitely restricted the way of thinking about the pathogenesis of this heterogeneous disease, resulting in a lack of knowledge concerning the molecular and cell biology of COPD and few advances in therapy today. According to the new definition developed by the Global Initiative for Chronic Obstructive Lung Disease (GOLD) expert panel in 2001, the airflow limitation in COPD is associated with an abnormal inflammatory response of the lungs to noxious particles of gases ${ }^{2}$. Thus, COPD is increasingly recognized as a chronic inflammatory disorder. The studies described in this thesis were performed to obtain better insight in the chronic inflammatory processes that are suggested to contribute to the pathogenesis of COPD. The specific aims were to investigate the relationship between local and systemic inflammation in COPD patients, and to further characterize the local inflammatory response (Chapter 36). In addition, the effects of acute and long-term LPS exposure to the lung in vivo were studied using an experimental animal model (Chapter 7-9). In this chapter, the results of the studies presented in this thesis will be considered in the context of the available literature. In addition, future lines of investigation will be discussed.

\section{PULMONARY INFLAMMATION IN COPD}

There is increasing evidence that COPD is associated with a chronic inflammatory response throughout the airways, lung parenchyma, and pulmonary vasculature, with certain variations in inflammatory cells in the different compartments of the lung. As outlined in Chapter 1, cellular inflammatory infiltrates and production of inflammatory mediators, proteinases, and reactive nitrogen and oxygen species are all thought to contribute to the pathologic changes characteristic for COPD. Studies described in Chapter 3-5 were performed to further characterize the local inflammatory response in COPD, hereby focusing on cellular infiltrates, chemokines (IL-8), cytokines (TNF- $\alpha$, leptin), soluble cytokine receptors (STNFR55, sTNF-R75), acute-phase reactants (AGP, LBP, CRP). We demonstrate elevated levels of the various types of inflammatory mediators mentioned in induced 
TNF- $\alpha$ as potential therapeutic target in RA and IBD required extensive studies of not just cytokine expression, but also cytokine regulation. To this end, in vitro (or ex vivo) models were used to understand the disease process, and animal models were developed to confirm the in vitro findings ${ }^{16}$.

Future research of COPD has to run through different stages. First, COPD has to be generally accepted as a chronic inflammatory disease, as worldwide research is necessary to gain more knowledge about all aspects of inflammation in COPD. Second, in vitro (ex vivo) studies are crucial to elucidate underlying mechanisms of chronic inflammatory processes in COPD, perhaps also in different stages of the disease. Stimulation experiments in cell lines, and primary cultures in particular, are important to understand reactivity of lung cells to noxious particles and gases. In this respect, it is essential to learn more about the persistence of the inflammatory response after smoking cessation. Knowledge from in vitro studies will lead to new hypotheses concerning molecular mechanisms and therapeutical targets. Third, these new hypotheses have to be preferentially evaluated in proper animal models of COPD. Last, integration of multiple disciplines like in IBD and RA will accelerate progress in investigations of COPD, providing a more coherent knowledge and understanding of the molecular mediators and mechanisms of chronic inflammation and tissue injury.

\section{COPD MODELING}

As indicated above, future investigations should also be extended to animal models, in which the many unsolved issues in COPD, such as mechanisms of airflow obstruction, inflammatory cell recruitment, persistence of chronic inflammation, and abnormal repair, can be studied. In the past, many animal models for emphysema have been developed (Chapter 1). Exogenous administration of proteinases, chemicals, particulates, and exposure to cigarette smoke was demonstrated to result in pathologic features characteristic of human emphysema. In addition, airspace enlargement during development and throughout life was demonstrated in genetic manipulated mice (both gain and loss of function models). To date, however, no satisfactory animal model mimicking both chronic inflammation and pathologic changes in COPD was available that is suitable for early drug testing.

Recently, bioactive LPS was demonstrated to be present at high levels in cigarette smoke ${ }^{3}$. Since long-term cigarette smoking is the major environmental factor that predisposes patients to COPD, LPS present in cigarette smoke is a good candidate triggering smoking-induced accumulation of inflammatory cells in respiratory bronchioles, alveolar ducts, and alveoli in cigarette smokers susceptible for COPD. In addition, chronic exposure to significant levels of LPS was reported to be associated with the development and/or progression of COPD. Therefore, animal studies were performed to investigate the effects of acute and long-term LPS exposure to the lung in vivo in more detail (Chapter 7-9).

Previous studies have demonstrated that single IT LPS challenge results in a 
rapid but transient inflammatory response, characterized by infiltration of neutrophils from the pulmonary vascular bed into the respiratory air spaces ${ }^{17,18}$. In Chapter 7 and 8, we demonstrate that acute exposure of the lung to LPS has broad-spectrum inflammatory effects both locally and systemically, but also triggers rapid tissue injury at the local level.

Of interest in COPD is chronic exposure to LPS. In Chapter 9, we show that long-term LPS exposure results in persistent chronic inflammation in airways and parenchyma with altered cytokine expression, hereby supporting the idea that ongoing inflammatory processes results from an altered cytokine balance, involving cytokines derived from inflammatory cells. In addition, chronic LPS exposure was shown to induce significant airway and alveolar abnormalities. The inflammatory and pathological changes observed in mice exposed to repeated local LPS exposure mimic important features observed in human subjects with COPD. Therefore, this murine model may be applicable to dissect the role of chronic inflammation in the pathogenesis of COPD. Using intervention strategies, the involvement of a single inflammatory mediator or specific inflammatory cells in the process of LPS-induced chronic inflammation can be studied. In addition, the combination of gene targeting (overexpression and knock-out models) with this LPS exposure model will supply information about individual candidate genes that may contribute to the pathology induced by long-term LPS exposure. As both inflammatory and pathological changes were induced by repeated local LPS exposure, this model may also be suitable for early testing of drugs regarding inflammation or proteolytic damage. To this end, however, further characterization of the model will be necessary, including local inflammation and tissue injury, lung function, and systemic inflammation.

\section{CLOSING REMARKS}

We are now only at the beginning of better understanding the disease process of COPD. More research concerning chronic inflammation in COPD is clearly necessary to identify therapeutic targets in COPD and effective therapy. In vitro studies and animall studies will contribute to our present understanding of lung and airway inflammation, and its involvement in the pathogenesis of COPD. In addition, studies investigating genetic susceptibility are essential to identify genetic factors important in COPD. Better insights into the pathogenesis of COPD will contribute not only to modulation of the disease process, but may direct future early intervention strategies in order to avoid progression to a state of functional impairment and disablement of patients suffering from this disease. Basic insight into the pathogenesis of this disease process will support raising expectations in the management of these patients, in order to attenuate the future burden of COPD worldwide. 


\section{REFERENCES}

1. ATS. Staridards for the diagnosis and care of patients with chronic obstructive pulmonary disease. Am / Respir Crit Care Med 1995;152:577-121.

2. Pauwels RA, Buist AS, Calverley PM, Jenkins $C R$, and Hurd SS, Global strategy for the diagnosis, management, anid prevention of chronic obstructive pulmonary disease. NHLBU/WHO Gilobal Initiative for Chronic Obstructive Lung Disease (GOLD) Workshop summary. Am / Respir Crit Care Med 2001:163:1256-1276.

3. Hasday JD, Bascom $R$, Costa $J$, Fitzgerald $T$, and Dubin $W$. Bacterial endotoxin is an active component of cigarette smoke. Chest 1999;115:829-835.

4. Anthonisen NR, Connett JE, Kiley JP, Altose MD, Balley WC, Buist AS, Conway WA, Jr, Enright $\mathrm{PL}$, Kanner RE, OHara $\mathrm{P}$, and et. al. Effects of smoking intervention and the use of an inhalled anticholinergic bronchodilator on the rate of decline of FEV1. The Lung Health Study. Jama $1994 ; 272: 1497-1505$.

5. Scanlon $\mathrm{PD}$, Connett $\mathrm{E}$, Waller $\mathrm{LA}$, Altose $M \mathrm{MD}_{\text {, Bailey }} \mathrm{WC}_{r}$ and Buist $\mathrm{AS}$. Smoking cessation and lung function in mild-to-moderate chronic obstructive pulmonary disease. The Lung Health Study. Am J Respir Crit Care Med 2000;161:381-390.

6. Kanner RE, Connett JE, Williams DE, and Buist AS. Effects of randomized assignment to at smoking cessation intervention and changes in smoking habits on respiratory symptoms in smokers with early chronic obstructive pulmonary disease: the Lung Health Study. Am I Med 1999;106:410-416.

7. Mullen $\mid \mathrm{B}$, Wright $\mathrm{JL}$, Wiggs $\mathrm{BR}$, Pare $\mathrm{PD}$, and Hogg JC. Structure of central airways in current smokers and ex-smokers with and without mucus hypersecretion: relationship to lung function. Thorax $1987 ; 42: 843-848$.

8. Turato G, Di Stefano A, Maestrelli P, Mapp CE, Ruggieri MP, Roggeri A, Fabbri LM, and Saetta M. Effect of smoking cessation on airway inflammation in chronic bronchitis. Am / Respir Crit Care Med 1995;152:1262-1267.

9. Yamamoto $C_{y}$ Yoneda T, Yoshikawa M, Fu A, Tokuyama T, Tsukaguchi K, and Narita N. Airway inflammation in COPD assessed by sputum levels of interleukin-8. Chest 1997;112:505-510.

10. Rutgers SR, Postma DS, ten Hacken NH, Kauffman HF, van Der Mark TW, Koeter GH, and Timens $W$. Ongoing airway inflammation in patients with COPD who do not currently smoke. Thorax 2000;55:12-18.

11. Willemse BW, Ten Hacken NH, Rutgers B, G. L, Postma DS, and Timens W. The effect of one year smoking cessation on neutrophilic inflammation in smokers with and without COPD. Am I Respir Crit Care Med 2002;165:A463.

12. Farrell Ry, and Peppercorn MA. Ulcerative colitis. Lancet 2002;359:331-340.

13. Shanahan F. Crohn's disease. Lancet 2002;359:62-69.

14. Keating $\mathrm{CM}$, and Perry $\mathrm{CM}$. Infliximab: an updated review of its use in Crohn's disease and rheumatoid arthritis. BioDrugs 2002;16:111-148.

15. Abuzakouk $M$, freighery $C$, and Jackson J. Tumour necrosis factor blocking agents: a new therapeutic modality for inflammatory disorders. Br J Biomed Sci 2002;59:173-179.

16. Feldmann $M$, and Maini RN. Discovery of TNF-alpha as a therapeutic target in rheumatoid arthritis: preclinical and clinical studies. Joint Bone Spine 2002;69:12-18.

17. Hirano S. Quantitative time-course profiles of bronchoalweolar lavage cells following intratracheal instillation of lipopolysaccharide in mice. Ind Heath 1997;35:353-358.

18. Ulich TR, Yin $S$, Guo $K, Y$, ES, Remick $D$, and del Castillo J. Intratracheal injection of endotoxin and cytokines. II. Interleukin-6 and transforming growth factor beta inhibit acute inflammation. Am/ Pathol 1991:138:1097-1101. 


\title{
CHAPTER 11
}

\author{
Summary
}

\section{INTRODUCTION}

In the present thesis, the following topics were studied:

- The relationship between local and systemic inflammation in COPD patients, and further characterization the local inflammatory response;

- The effects of acute and long-term LPS exposure to the lung in vivo in an experimental animal model.

Below, the results of the studies on these topics are shortly summarized.

\section{THE RELATIONSHIP BETWEEN LOCAL AND SYSTEMIC INFLAMMATION IN COPD PATIENTS}

Chronic inflammation is an important feature of COPD. This inflammatory response is not restricted to the local compartment - including airways, lung parenchyma, and pulmonary vasculature - but is also present in the circulation. However, the origin of the systemic inflammation present in COPD patients remains still to be elucidated. In Chapter 3 and 4, we investigated the relationship between the local inflammatory response in the respiratory organ and systemic inflammation in patients with mild-to-moderate COPD. We assessed airway inflammation using induction of sputum by inhalation of hypertonic saline, which is a safe, non-invasive, and reproducible method to determine cell counts and protein concentrations in the airway compartment of subjects.

In Chapter 3, levels of sTNF-receptors, TNF- $\alpha$, and IL- 8 in induced sputum and plasma were compared between COPD patients and healthy smokers. COPD patients appeared to have significantly higher percentages of neutrophils and levels of STNF-receptors and $1 \mathrm{~L}-8$ in induced sputum as compared to healthy smokers. These parameters highly correlated with each other and with the degree of airflow limitation. In contrast, sputum TNF- $\alpha$ levels were similar in both groups. When comparing levels of inflammatory mediators in sputum and plasma, no direct correlations were found. In addition, sputum levels of sTNF-receptors were related with degree of airflow limitation in the COPD group, whereas plasma levels were not. These observations suggests that the systemic inflammatory response in COPD is not due to an overflow of inflammatory mediators from the local compartment, but that the inflammatory processes in the local and systemic compartment are differently regulated. 
In Chapter 4, levels of three major acute-phase reactants -AGP, CRP, and LBPwere assessed in induced sputum and plasma of COPD patients and healthy smokers. Sputum levels of AGP and LBP were significantly increased in COPD patients versus healthy smokers, and inversely correlated with the $\mathrm{FEV}_{1}$ values in COPD. In contrast, sputum CRP was not different between the study groups. In plasma, LBP was markedly elevated in COPD patients versus healthy smokers, whereas circulating levels of AGP and CRP tended to be increased in COPD. In contrast to sputum, AGP and LBP in plasma were positively related to the FEV, values. Exploring the relationship between local and systemic acute-phase response, no direct relations, which suggests that acute-phase reactants in sputum may be due to local production rather than leakage from the systemic compartment.

\section{FURTHER CHARACTERIZATION THE LOCAL INFLAMMATORY RESPONSE IN COPD PATIENTS}

Increased levels of several cytokines and chemokines have been found in association with COPD. However, overall fundamental questions regarding the specific role inflammatory mediators and mechanisms of inflammatory cell recruitment in COPD are still remaining because our knowledge about chronic inflammation is still fragmentary. In order to get insight in the underlying mechanisms of the chronic inflammation in COPD, we further characterized the local inflammatory response.

As indicated above, COPD patients had levels of sTNF-receptors, in particular sTNF-R55, in induced sputum as compared to healthy smokers (Chapter 3). In addition, increased levels of ACP and LBP were demonstrated in COPD sputum as compared to controls (Chapter 4). Our data on smoking cessation (Chapter 3) suggest an ongoing inflammation in airways and circulation of COPD patients after smoking cessation.

Leptin, initially discovered as a regulator of food intake and energy expenditure, is emerging as a pleiotropic cytokine involved in immune and inflammatory responses. In Chapter 5, we focused on the role of leptin as proinflammatory mediator in the local inflammatory response in COPD. Leptin was detectable in induced sputum of male COPD patients. Sputum leptin showed a strong positive correlation with sputum levels of CRP and TNF- $\alpha$, whereas leptin was inversely related to sTNF-receptors in sputum. These correlations may indicate that leptin is involved in the local inflammatory response in COPD.

In Chapter 6, we paid attention to on another aspect of the local inflammatory response, that is the proteinase-anti-proteinase imbalance in COPD. MMPs are suggested to play a critical role in the development and progression of COPD, but quantitative data on MMP activity in airways are lacking. Using specific immunocapture assays that allow determination of both active and potentially activatable (total) MMPs, we compared activity of MMP-1, MMP-8, and MMP-9 in sputum of COPD patients and healthy smokers. COPD patients appeared to have increased 
sputum activity of MMP-8 and MMP-9, whereas MMP-1 activity was not increased. MMP-8 and MMP-9 (active and total) were strongly correlated, and were related to the absolute number of neutrophils in both study groups. In addition, an inverse correlation between MMP-8 and MMP-9 activity in sputum and airflow obstruction $\left(\mathrm{FEV}_{1}\right)$ was found in the combined study groups. Immunohistochemistry demonstrated strong positive staining for MMP-9 in both alveolar macrophages and neutrophils, whereas specific staining for MMP-8 was. exclusively observed in neutrophils. The presence of increased MMP-8 and MMP9 activity in the airways of COPD patients supports the concept of an impaired proteinase-anti-proteinase imbalance in COPD.

\section{THE EFFECTS OF ACUTE AND CHRONIC LPS EXPOSURE TO THE LUNG IN MICE}

Lipopolysaccharide (LPS) is ubiquitously present as contaminant on airborne particles, including air pollution and organic dusts. Chronic exposure to significant levels of LPS was reported to be associated with the development and/or progression of many types of lung diseases, including COPD. Recently, bioactive LPS was demonstrated to be present at high levels in cigarette smoke. Since longterm cigarette smoking is the major environmental factor that predisposes patients to COPD, LPS present in cigarette smoke may be a candidate to trigger smokinginduced accumulation of macrophages, lymphocytes, and neutrophils in respiratory bronchioles, alveolar ducts, and alveoli in susceptible cigarette smokers. Therefore, we performed animal studies to investigate the effects of acute and long-term LPS exposure to the lung in vivo in more detail.

To study the effects of acute LPS on inflammation and tissue injury, we made use of a well-characterized murine model. Single intratracheal instillation of $5 \mu \mathrm{g}$ LPS resulted in a rapid but transient inflammatory response, characterized by elevated TNF- $\alpha$ expression and a profound infiltration of neutrophils from the pulmonary vascular bed into the respiratory air spaces (Chapter 7). In addition, local LPS exposure appeared to result in early apoptosis of bronchial epithelial cells independent of infiltrating neutrophils and TNF- $\alpha$. This indicates that exposure of the lung to LPS not only induces pulmonary inflammation, but may allso be directly involved in rapid airway injury.

Expression of acute-phase reactants (APRs) at the site of LPS exposure may enhance the early innate immune response to injury and infection. Therefore, the effects of local LPS exposure on both pulmonary and hepatic expression of four major acute-phase proteins - SAP, AGP, LBP, and $\alpha_{1}$-AT - were assessed (Chapter 8). Local LPS exposure in mice resulted in a rapid increase of mRNA expression for three major APRs ( $\alpha_{1}-\mathrm{AT}, \mathrm{AGP}$, and LBP) in the lung. In addition, exposure to LPS in the pulmonary compartment resulted in elevated levels of AGP, LBP, and SAP in the circulation, which was consistent with the APR expression pattern in the liver. Furthermore, the increased plasma IL-6 levels after local LPS exposure suggest that IL-6 acts as mediator between the pulmonary and hepatic system. As local 
production of APRs results in higher concentrations in the intra-alveolar compartment and shortens the time path, pulmonary expression of APRs may be more efficient than extravasation of serum APRs to control the early phase of innate immunity to injury and infection.

In Chapter 9, the inflammatory and pathological effects of long-term LPS exposure to the lung were investigated in detail. To this end, a novel murine model in which mice were exposed to repeated intratracheal instillation of E.coli LPS was developed. Long-term LPS exposure was shown to result in chronic inflammation, characterized by peribronchial and perivascular lymphocytic aggregates $(\mathrm{CD} 4+, \mathrm{CD} 8+$, and $\mathrm{CD} 19+)$, parenchymal accumulation of macrophages and CD8 $+\mathrm{T}$ cells, and altered cytokine expression (TNF- $\alpha, \mathrm{IL}-18$ and $(\mathrm{FN}-y)$. The absence of neutrophils indicates that neutrophil infiltration is rather a transient process triggered by each LPS exposure instead of being a chronic factor. In addition, long-term LPS exposure resulted in significant airway and alveolar alterations such as increased mucus cell metaplasia in larger airways, thickening of the airway smooth muscle layer, and irreversible alveolar enlargement without proliferation of alveolar epithelial cells. Interestingly, the observed inflammatory and pathological changes in mice exposed to repeated local LPS exposure mimic important features observed in human subjects with chronic pulmonary inflammatory disorders, especially COPD. Therefore, this murine model could be applicable to dissect the role of inflammation in the pathogenesis of these disease conditions.

Chapter 10 comprises the general discussion of the thesis and gives implications for future investigations. 


\section{CHAPTER 12}

\section{Nederlandse samenvatting}

\section{LONGEN}

De longen zijn verantwoordelijk voor de zuurstofvoorziening in ons lichaam. Het goed functioneren van de longen is dus van levensbelang. De longen bestaan uit luchtwegen omringd door longblaasjes. De luchtwegen beginnen in de luchtpijp, en eindigen na een groot aantal vertakkingen in achtereenvolgens grote, middelgrote en kleine luchtwegen, uiteindelijk in de longblaasjes. De gasuitwisseling (van zuurstof en kooldioxide) vindt plaats tussen de wanden van de kleinste luchtwegen en longblaasjes, en hele kleine bloedvaatjes die dit weefsel omgeven (Figuur 1).
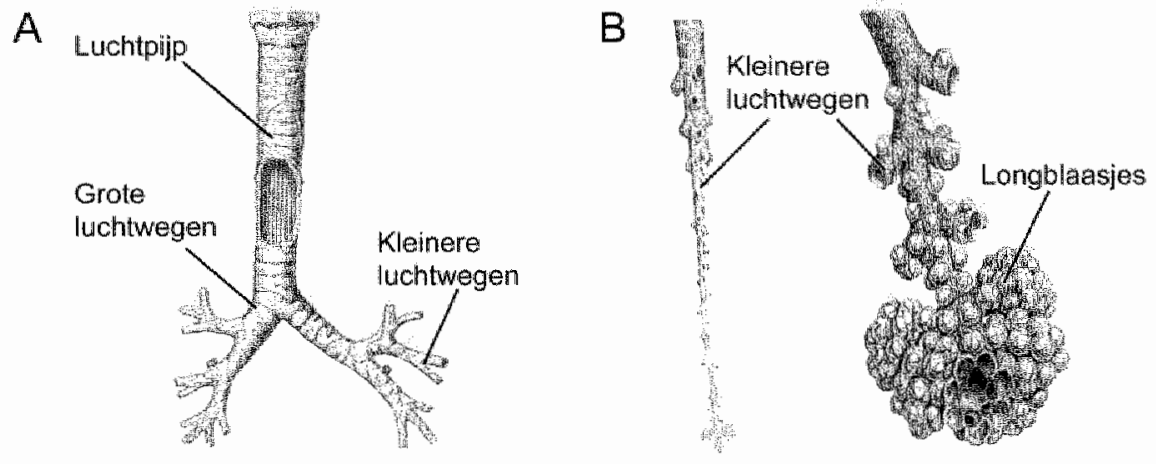

Figutur 1 . Schematische weergave van $(A)$ het lagere ademhalingskanaal met de luchtpipp, de grote luchtwegen en de kleinere luchtwegen; $(B)$ het gaswisselingsweelsel mel de kleinere luchtwegen en de longblaasjes (Uit: Netter Allas of Human Anatomy).

\section{COPD}

"Chronic obstructive pulmonary disease", ofwel COPD, is de engelstalige benaming voor chronisch obstructieve longziekten. COPD is een chronische aandoening van de longen, die zich meestal op latere leeftijd uit in een geleidelijk en grotendeels onomkeerbare verslechterende longfunctie. Patiënten met COPD hebben longemfyseem, chronische bronchitis of een combinatie van beide ziektebeelden. Longemfyseem wordt gekenmerkt door versnelde afbraak van het elastische steunweefsel in de longen ("de rek is uit de long"). Dit leidt tot een 
beschadiging en uiteindelijk verlies van longblaasjes. Hierdoor kan de gasuitwisseling in de longen minder goed plaatsvinden. Patiënten met chronische bronchitis hebben een voortdurend terugkerende overmatige slijmproductie in de luchtwegen, die vaak gepaard gaat met luchtweginfecties. Dit slijm zorgt voor vernauwing van de luchtwegen (obstructie). Hierdoor wordt de ademhaling ernstig bemoeilijkt. Veel voorkomende klachten bij COPD patiënten zijn dan ook kortademigheid, sputum (slijm) productie, veelvuldig hoesten en/of een piepende ademhaling.

Roken wordt gezien als de belangrijkste risicofactor voor de ontwikkeling van COPD. $80-85 \%$ van de patiënten met COPD is dan ook jarenlang een (zware) roker (geweest). Een belangrijk gegeven is echter dat niet alle rokers, maar slechts $10-20 \%$ in de loop der jaren COPD ontwikkelt. Dit betekent dat ook (tot nu toe onbekende) genetische factoren een rol spelen bij de ontwikkeling van COPD. Behalve het stoppen met roken, zijn er tot op heden geen effectieve behandelingen woorhanden die het ontstaan en het verloop van de ziekte kunnen remmen.

Door de hoge morbiditeit (voorkomen van klachten) en de hoge mortaliteit (overlijden aan de ziekte) van de ziekte, heeft COPD enorme (financiële) gevolgen voor de samenleving. Veel van de patiënten moeten hun werk opgeven, er moeten hoge kosten gemaakt worden voor bezoeken aan artsen en therapie, voor ziekenhuisopnames, en voor thuisbehandeling met zuurstoftherapie. De sterfte ten gevolge van COPD neemt nog steeds toe. De verwachting is dat COPD door de toenemende vergrijzing en luchtvervuiling in 2020 wereldwijd de derde doodsoorzaak zal zijn, na longkanker en AIDS. De geschatte mortaliteit is dan 4,7 miljoen personen per jaar.

Beter inzicht in de mechanismen die de basis vormen van de ontwikkeling en voortgang van COPD is noodzakelijk om uiteindelijk te komen tot effectieve therapieën. Het is duidelijk geworden dat chronische ontstekingsprocessen in de longen - inclusief de luchtwegen, longblaasjes en bloedvaten - een belangrijke rol spelen bij de vermindering van de longfunctie en in de longklachten van patiënten met COPD. In de afgelopen jaren is ook ontdekt dat deze ontstekingsreacties zich niet beperken tot de longen (lokale ontsteking), maar ook aanwezig zijn in de bloedbaan (systemische ontsteking). De oorzaak van de ontstekingsreacties in de bloedbaan van COPD patiënten is echter nog steeds onbekend.

\section{LIPOPOLYSACCHARIDE}

Lipopolysaccharide (LPS) is een belangrijk bestanddeel van de celwand van zogenaamde Gram-negatieve bacteriën. LPS is aanwezig op stofdeeltjes die voorkomen in de lucht die we inademen, zoals luchtverontreiniging, huisstof en organisch stof. Zoals schematisch is weergegeven in Figuur 2, bestaat LPS uit een vetgedeelte (phospholipid) en een suikerstaart (polysaccharide) en juist het vetgedeelte heeft sterke ontstekingsbevorderende eigenschappen. Verschillende studies hebben een relatie aangetoond tussen langdurige blootstelling aan hoge 
concentraties LPS op stofdeeltjes en het ontstaan van chronisclie longaandoeningen, zoals astma en COPD. Recent is ontdekt dat bioactief LPS ook aanwezig is in sigarettenrook. Aangezien roken de belangrijkste risicoffactor is voor het krijgen van COPD, zou LPS een belangrijke factor kunnen zijn in de voortgang van ontstekingsprocessen in COPD. Tot nu toe is er weinig onderzoek gedaan naar de effecten wan chronische LPS blootstelling op ontstekingsprocessen in de longen.

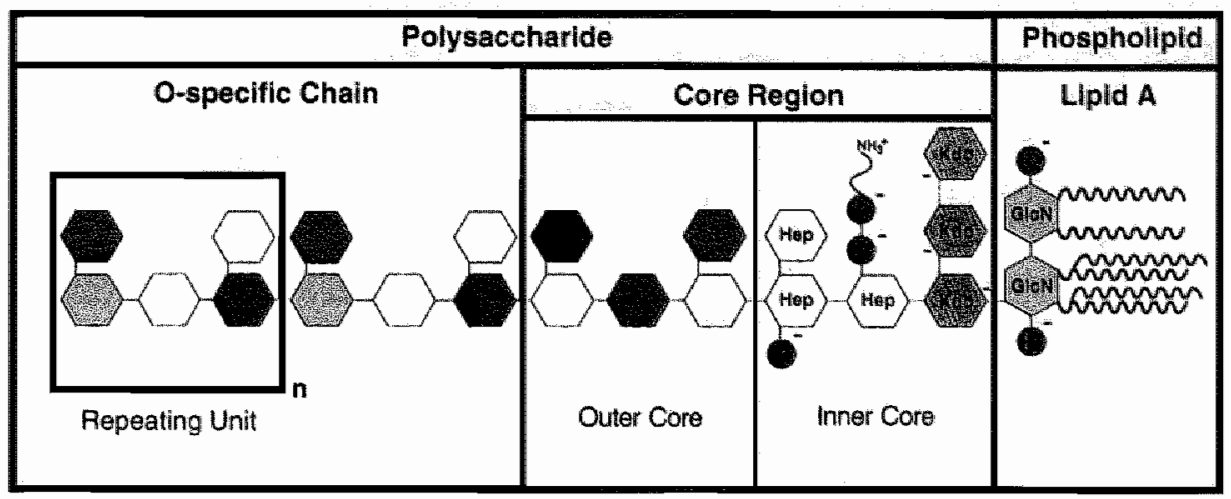

Figur 2. Schematische weergave van lipopolysaccharide (LPS) met het vetgedeelte (phospholipid) en de suikerstaart (polysaccharide) (Uit: Alexander $\mathcal{C}$ en Rietschel ET. Bacterial lipopolysaccharides and innate immunity. J Endotoxin Res 2001; 7:167-202\%.

\section{DOEL VAN HET ONDERZOEK}

Het doel van het onderzoek is om meer inzicht te krijgen in de ontstekingsprocessen, zoals die voorkomen bij patiënten met COPD. Hiertoe hebben wij onderzoek gedaan naar:

- De ontstekingsprocessen in de luchtwegen en de bloedbaan bij COPD patiënten en de relatie tussen deze processen;

- De effecten van acute of langdurige blootstelling aan LPS op de longen door gebruik te maken van een dierexperimenteel model.

\section{LOKALE EN SYSTEMSICH ONTSTEKINGSREACTIES IN COPD}

Goed inzicht in de ontstekingsreacties in de longen en de bloedbaan is van belang voor toekomstige behandeling én preventie van COPD. Tot nu toe is onze kennis over chronische ontstekingsprocessen in COPD beperkt en slechts gebaseerd op enkele studies in meestal ernstige COPD patiënten. In Hoofdstuk $3 \mathrm{t} / \mathrm{m} 6$ hebben we (lokale) ontstekingprocessen in de luchtwegen en (systemische) ontstekingprocessen in de bloedbaan van patiënten met COPD bestudeerd en dit vergeleken met gezonde rokende vrijwilligers. Aangezien het niet mogelijk is om 
zomaar een stukje longweefsel weg te nemen zonder medische reden, hebben we gebruik gemaakt van opgewekt sputum (slijm) om ontstekingscellen en opgeloste stoffen (mediatoren) in de luchtwegen te bestuderen. Dit sputum wordt op een eenvoudige en veilige manier opgewekt (losgeweekt) door het inademen van een nevel van zout water. Daarna wordt het sputum opgehoest. Ook is een buisje bloed afgenomen om de ontstekingsprocessen in de bloedbaan te kunnen meten.

In Hoofdstuk 3 hebben we verschillende typen ontstekingscellen en ontstekingsmediatoren (IL-8, TNF- $\alpha$ en oplosbare receptoren voor TNF- $\alpha$ ) bestudeerd in opgewekt sputum en bloedplasma. COPD patiënten bleken meer neutrofielen (een bepaalde ontstekingscel) en ontstekingsmediatoren in hun sputum te hebben vergeleken met gezonde rokers. Fen andere belangrijke bevinding was dat er een sterk verband was tussen de mate van lokale ontsteking en de longfunctie. Individuen met meer ontstekingscellen en/of ontstekingsmediatoren in hun sputum hadden namelijk een slechtere longfunctie. Ook in de bloedbaan van COPD patiënten werden meer ontstekingsmediatoren gevonden dan bij gezonde rokers, maar dit was niet gerelateerd aan de longfunctie. Daarna werden de waarden van de ontstekingsmediatoren vergeleken tussen sputum en bloed, maar het bleek dat er geen verband bestond tussen de mate van lokale en systemische ontsteking. Deze resultaten suggereren dat de systemische ontsteking niet het gevolg is van lekkage van mediatoren vanuit de long.

In Hoofdstuk 4 werd een andere groep van mediatoren bestudeerd in opgewekt sputum en bloedplasma, namelijk acute-fase eiwitten (AGP, CRP en L.BP). De precieze functies van de verschillende acute-fase eiwitten is nog onduidelijk, maar ze spelen zeker een belangrijke rol bij de verdediging van het lichaam tijdens infecties en/of ontsteking. Concentraties van AGP en LBP (maar niet CRP) waren duidelijk verhoogd in sputum van COPD patiënten. Net als de ontstekingsmediatoren (Hoordstuk 3) waren hoge concentraties van AGP en LBP in sputum gerelateerd aan een slechte longfunctie. In bloedplasma was alleen LBP verhoogd in COPD patiënten, dit was juist gerelateerd aan een goede longfunctie. Ook nu vonden we geen verband tussen de lokale en systemische ontstekingsprocessen in COPD. Deze resultaten suggereren dat de acute-fase eiwitten gemeten in sputum lokaal in de long gemaakt worden, en bijdragen aan de lokale verdediging van de long.

In Hoofdstuk 5 hebben we leptine bestudeerd. Leptine is een hormoon dat een belangrijke rol speelt bij de regulatie van de energiebalans in ons lichaam. Recent is ontdekt dat leptine ook betrokken is bij ontstekingsprocessen. Daarom hebben we onderzocht of leptine voorkomt in sputum van COPD patiënten en mogelijk kan dienen als een marker van ontstekingsprocessen in de long. Leptine bleek inderdáad aanwezig te zijn in sputum van COPD patiënten en duidelijke relaties werden gevonden met concentraties van CRP en TNF- $\alpha$ in sputum. Deze resultaten suggereren dat leptine betrokken is bij de lokale ontstekingsprocessen in de long van COPD patiënten.

In Hoofdstuk 6 werd aandacht besteed aan een ander aspect van de lokale ontsteking, namelijk activiteit van matrix metalloproteinases (MMP's) in sputum. 
MMP's zijn enzymen die andere eiwitten kunnen afbreken en sterke activiteit van $M M P^{r}$ s kan zo leiden tot beschadiging cq. afbraak van weefselstructuren, zoals longblaasjes. Recente studies laten zien dat concentraties van MMP's verhoogd zijn in de long (longspoelsel, sputum, longweefsel) van COPD patiènten, echter de activiteit van MMP's is tot nu toe niet gemeten. Door gebruik te maken van een nieuwe meetmethode hebben we de activiteit van verschillende MMP's (MMP-1, MMP-8 en MMP-9) in sputum kunnen meten. COPD patiënten bleken een verhoogde activiteit van MMP-8 en MMP-9 te hebben vergeleken met gezonde rokers. Verhoogde MMP activiteit was sterk gerelateerd aan een slechte longfunctie. Met behulp van antistoffen werd vervolgens gekeken welke ontstekingscellen aanwezig in opgewekt sputum deze MMP's maken. Het bleek dat MMP-8 alleen door neutrofielen gemaakt werd, terwijl zowel neutrofielen als macrofagen (een ander type ontstekingscel) het MMP-9 maken. Deze resultaten ondersteunen de hypothese dat MMP's een belangrijke rol spelen in het ontstaan en de voortgang van COPD.

\section{EFFECTEN VAN ACUTE EN CHRONISCHE LPS BLOOTSTELLING OP DE LONG}

Om de effecten van acute en chronische LPS blootstelling op de long te bestuderen, werden verschillende dierexperimentele studies uitgevoerd (Hoofdstuk $7 \mathrm{t} / \mathrm{m}$ 9). We hebben hiervoor gebruik gemaakt van een model, waarbij muizen via de luchtpijp (lokaal) $5 \mu \mathrm{g}$ LPS kregen toegediend.

In Hoofdstuk 7 hebben we gekeken naar acute ontstekingsreacties en acute schade aan het longweefsel veroorzaakt door eenmalige blootstelling aan LPS. Het bleek dat lokale LPS blootstelling resulteerde in een productie van ontstekingsmediatoren (TNF- $\alpha$ ) en ophoping van neutrofielen in de longen. Er was echter ook directe schade door lokale LPS toediening, onafhankelijk van deze acute ontstekingsreactie: een deel van de bronchiale epitheelcellen (cellen die de binnenwand van de luchtwegen bekleden) bleek namelijk dood (in apoptose) te gaan. Deze studie toont aan dat blootstelling van longen aan LPS niet alleen leidt tot acute ontstekingsreacties, maar ook direct betrokken is bij beschadiging van de luchtwegen.

In Hoofdstuk 8 werd het effect van LPS blootstelling in de long op de productie van vier acute-fase eiwitten - SAP, AGP, LBP en $\alpha_{1}-\mathrm{AT}$ - in de long, de lever en de bloedbaan bestudeerd. De lever is het orgaan wat normaal zorg draagt voor de productie van acute-fase eiwitten, die via de bloedbaan naar de rest van het lichaam, inclusief de longen, worden getransporteerd. Het bleek dat lokalle blootstelling aan LPS leidde tot een snelle productie van acute-fase eiwitten in de long. Deze resultaten suggereren dat de lokaal gemaakte acute-fase eiwitten bijdragen aan een snelle adequate verdediging van de long tijdens infectie en/of ontsteking. Ook werden verhoogde waarden van acute-fase eiwitten in de bloedbaan gemeten. Het bleek dat tevens de lever geactiveerd werd tot productie van acute-fase eiwitten door LPS blootstelling in de long. Deze resultaten tonen aan dat blootstelling van longen aan LPS niet alleen lokale effecten heeft, maar ook 
leidt tot activatie van de lever.

In Hoofdstuk 9 zijn de effecten van langdurige blootstelling aan LPS bestudeerd op ontstekingsprocessen en schade in de long. Hiertoe werd een nieuw muizenmodel ontwikkeld: muizen werden 2 keer per week blootgesteld aan $5 \mu \mathrm{g}$ LPS gedurende 12 weken. Het bleek dat deze langdurige lokale LPS blootstelling leidde tot een ontstekingspatroon, dat zelfs 8 weken na de laatste LPS blootstelling bleef bestaan. Daarom spreken we hier van een chronische ontstekingsproces. Verder bleek dat langdurige LPS blootstelling leidde tot chronische schade aan de long die lijkt op de longschade zoals die voorkomt bij patiënten met COPD: verhoogde aantallen slijmproducerende cellen, verdikking van de spierlaag rondom de luchtwegen en afbraak van de wand van longblaasjes. Dit nieuwe model lijkt geschikt om de relatie tussen de chronische ontstekingsprocessen en schade in de long te bestuderen.

\section{CONCLUSIES}

De belangrijkste conclusies uit de in dit proefschrift beschreven studies zijn:

1. De ontstekingsprocessen in de luchtwegen van COPD patiënten worden gekenmerkt door a) verhoogde aantallen meutrofielen, b) hogere concentraties ontstekingsmediatoren en acute-fase eiwitten, en c) verhoogde activiteit van MMP's in vergelijking met gezonde rokers;

2. COPD patiënten hebben een systemische ontsteking, die gekenmerkt wordt door hogere concentraties ontstekingsmediatoren en acute-fase eiwitten in vergelijking met gezonde rokers;

3. De mate van ontsteking in de longen (niet in de bloedbaan) is gerelateerd aan een slechtere longfunctie;

4. Er is geen verband gevonden tussen de lokale en systemische ontstekingsprocessen in COPD patiënten;

5. Acute LPS blootstelling in de longen van muizen leidt tot a) lokale ontsteking, b) directe longschade, c) lokale productie van acute-fase eiwitten en d) activatie van de lever;

6. Langdurige LPS blootstelling in de longen van muizen leidt tot chronische ontsteking en weefselschade gelijkend op COPD.

We hebben nog een lange weg te gaan om de ziekte COPD beter te begrijpen. Meer onderzoek naar chronische ontstekingsprocessen, zowel in de longen als in de bloedbaan, is nodig om aangrijpingspunten te vinden voor nieuwe behandelmethoden. Dierexperimentele studies kunnen hier een belangrijke bijdrage aan leveren. De huidige en toekomstige impact van deze ziekte voor de patiènt, de directe omgeving en de maatschappij vragen bovendien om een voortvarende aanpak van deze "silent killer". 


\section{Abbreviations}

\begin{tabular}{|c|c|c|}
\hline$\alpha_{1}-\mathrm{AT}$ & : & $\alpha_{1}$-antitrypsin \\
\hline$a-S M A$ & $:$ & $\alpha$-smooth muscle actin \\
\hline AGP & : & $\alpha_{1}$-glycoprotein \\
\hline APR & : & Acute-phase reactant \\
\hline AT & : & Annealing temperature \\
\hline BAL & $:$ & Bronchoalveolar lavage \\
\hline COPD & : & Chronic obstructive pulmonary disease \\
\hline $\mathrm{DTT}$ & : & Dithiothreitol \\
\hline dUTP & : & 2'-deoxy-uridine-5'-triphosphate \\
\hline ECM & : & Extracellular matrix \\
\hline ELISA & : & Enzyme linked immunosorbent assay \\
\hline $\mathrm{FEV}_{1}$ & : & Forced expiratory volume in 1 second \\
\hline$H \& E$ & : & Hematoxylin \& eosin \\
\hline $\mathbb{H F N}-\gamma$ & : & Interferon-gamma \\
\hline IL & : & Interleukin \\
\hline IP & : & Intraperitoneal \\
\hline IT & : & Intratracheal \\
\hline LBP & : & LPS binding protein \\
\hline$L_{M}$ & : & Mean linear intercept \\
\hline LM & : & ligation-mediated \\
\hline LPS & : & Lipopolysaccharide \\
\hline LT & : & Lymphotoxin \\
\hline $\mathrm{mAb}$ & : & Monoclonal antibody \\
\hline MMP & : & Matrix metalloproteinase \\
\hline mRNA & : & Messenger RNA \\
\hline MHC & : & Major histocompatibility complex \\
\hline MPO & : & Myeloperoxidase \\
\hline $\mathrm{pAb}$ & : & Polyclonal antibody \\
\hline PAS & : & Periodic acid-Schiff \\
\hline PCR & : & Polymerase chain reaction \\
\hline RT & : & Reverse transcriptase \\
\hline SAP & : & Serum amyloid $\mathrm{P}$ component \\
\hline s & : & Soluble \\
\hline SD & $:$ & Standard deviation \\
\hline SEM & : & Standard error of the mean \\
\hline$T N F-\alpha$ & : & Tumor necrosis factor alpha \\
\hline TNF-R55 & $:$ & TNF-receptor 55 \\
\hline TNF-R75 & : & TNF-receptor 75 \\
\hline TUNEL & : & $\begin{array}{l}\text { Terminal deoxynucleotidy\| transferase (TdT)-mediated } \\
\text { dUTP nick end-labelling }\end{array}$ \\
\hline
\end{tabular}




\section{Dankwoord}

Eindelijk is het tijdstip gekomen waarop ik me de afgelopen jaren zo verheugd heb. Het bedanken van al die mensen die me de afgelopen jaren gesteund hebben en zonder wie dit proefschrift er heel anders uitgezien zou hebben.

Allereerst mijn promotoren. Prof. Miel Wouters, bedankt voor uw vertrouwen, uw steun en de vrijheid die $u$ me gaf in de afgelopen jaren. Uw brede visie op het internationale onderzoek heeft ervoor gezorgd dat Maastricht wat betreft onderzoek naar ontsteking bij COPD nu duidelijk op de kaart staat. Ik weet zeker dat we samen in de komende jaren nog veel kwalitatief goed onderzoek kunnen doen.

Prof. Wim Buurman, toen jij me daags na mijn sollicitatiegesprek belde on te zeggen dat "jullie me graag wilden hebben", wist ik niet wat ik ervan moest denken. Het was me in het geheel niet duidelijk wat ik in de komende jaren zou moeten gaan onderzoeken. $\mathrm{k}$ ben er inmiddels achter dat dit ook niet te voorspellen was geweest: startend met hyaluronzuur, via LPS en muizen naar chronische ontsteking bij COPD patiënten. Ook een wetenschappelijk balletje kan raar rollen. Bedankt voor de vele gesprekken en je onmisbare hulp bij het schrijven van de manuscripten. Jouw onmetelijke kennis zal me altijd blijven verbazen.

En natuurlijk mijn co-promotor, Dr. Mieke Dentener. Ik wil je bedanken voor je steun, vooral tijdens mijn beginperiode als $\mathrm{AlO}$, en de leuke samenwerking tot nu toe. Ik hoop dat we nog lang samen kunnen werken om de chronische ontstekingsprocessen bij COPD te doorgronden.

De beoordelingscommissie onder leiding van Prof. dr. J.W. Cohen Tervaert en verder bestaande uit Prof. dr. C.A. Bruggeman, Prof. dr. R. Louis, Prof. dr. F.P. Nijkamp en Prof. dr. F.J. van Schooten, wil ik hartelijk bedanken voor het kritisch beoordelen van het proefschrift (binnen de beoogde periode!). Prof. Louis, thank you for your critical evaluation of this thesis.

Voor ik verder ga met collega's, vrienden en familie, wil ik even stilstaan bij het volgende. Als eerste zijn dit de proefdieren die het leven hebben gelaten voor de wetenschap. Verder de longpatiënten en vrijwilligers, die belangeloos (herhaaldelijk) hebben meegewerkt aan het onderzoek. Zonder jullie waren deze studies om meer inzicht te krijgen in de chronische ontstekingsprocessen bij COPD patiënten ECHT niet mogelijk geweest. Bedankt!

Alle collega's van de Capaciteitsgroep Pulmonologie in de loop der jaren wil ik bedanken voor de goede samenwerking: de inflammatie-groep Trudeke (samen zijn we sterk), Suzanne (de Pooh) en Herman-Jan (jammer dat Hornerheide niet in 
Maastricht ligt); de spierboys en girls Ramon(neke), Harry (hé, nieuw kapsel), room-mate Jos, Marco (RNA-en-zo), Kimberly (thank you for reading the manuscript, en dat Nederlands praten komt wel) en Annemie (onmisbaar voor statistische problemen). Het nieuwe Pul-lab heeft ons zeker dichter bij elkaar gebracht. En verder: Mariëlle, Erica R., Kirsten, Eva, Frits, Roelinka, Chris, Diederik, Marja, Mehmet, Marc, Esther, Anneke, Francine, Karin, André, Erica B. en Solange; en in Burlington-USA Yvonne en Niki.

Ook een woord van dank aan de stagières: Rudy, Pascal, Martijn, en natuurlijk Marlies, jullie inzet en enthousiasme is onmisbaar gebleken. Verder de stafleden, de arts-assistenten, de longfunctie afdeling en de meiden van het secretariaat: bedankt voor jullie interesse in en hulp bij het onderzoek.

Alle collega's van Algemene Heelkunde: Kees (nog een stukje vlaai!?), Nicole, (vraag het aan) Trudi, Daniëlle, Marloes, Erik, Mo, Kiyoko, Misha, Maarten, Jessica (bedankt voor de erfenis antilichamen), M.A.R.C., Anita, Bart, Isabel, Annemarie, Monique, Gaby, Judit, Patricia, François, Corine, Tim (dé PCR-man), Vincent, Mart-Jan, Dennis, Gabrie, Mick, Hans, en Jean; mijn ex-kamergenoten gedurende de jaren Yvonne, Marcel, Maaike, Marcella, Steffi, Davor, Steven, Martin en Karel; en de secretaresses Kim, Mickey, en Brigitte. Bedankt voor de leuke samenwerking en jullie collegialiteit.

Niet te vergeten een woord van dank aan alle collega's van andere afdelingen/diensten binnen en buiten Maastricht met wie ik prettig heb samengewerkt of dat nog steeds doe. Met name wil ik noemen: Robert-Jan, Jacques, Anique, Monique, Wendy en Coby (Pathologie, azM) alsook Paul (Pathologie Atrium Heerlen) voor alle hulp en advies de afgelopen jaren, en in de toekomst! Ben, Peter, Jacques (Farmacologie, UM) en Dirk, Ruud (RTIL, Maastricht). Peter, Harry en de andere medewerkers van de Centrale Proefdier Voorziening die de muizen altijd met liefde verzorgd hebben. Frederik-Jan, Geja, Ad, Theo, Jan (GRAT, UM); Sjoerd, Roel, Pieter (Orthopedie, azM) en Niels (Huisartsgeneeskunde, UM). Appie en Jo (AV-dienst, azM) voor het bewerken van mijn dia's tot perfecte figuren voor publicatie. Jan, Roeland, Adri en Natascha (TNO, Leiden) voor alle (toekomstige) MMP-bepalingen; en Jan, Lisette (Medische Microbiologie, azM) voor alle hulp bij sputumverwerking en meer.

Wie ik zéker niet kan vergeten zijn mijn familie en vrienden. Pap en Mam Peters, Marianne, Toon, Myline, Guyon, Oma Kuyer, en de overige familieleden van beide kanten. Karen en Marcel, Jacqueline en Peter, Godie en Danjo, Diana en Raymond, Diana en Richard, Corrie en Marc. Bedankt voor jullie getoonde interesse in mijn werk en de vele gezellige (spellen-) avonden. Ondanks het drukke leven maken we tijd voor elkaar, en dat ben ik heel erg gaan waarderen! Hierbij een speciaal woord van dank aan mijn paranimfen: Karen de Wolf en Jacqueline Smeijsters-Maschino, meiden, wij komen er wel!

Lieve mam, jij zou nu zeggen: "Pap zou trots op je zijn geweest". Dat weet ik. Ik 
wil jullie beide bedanken voor alle liefde, hulp en steun die jullie mij de afgelopen jaren op alle fronten gegeven hebben.

En tenslotte Alex. We kennen elkaar al zó lang en zijn al weer bijna 4 jaar getrouwd. Je bent én blijft mijn alles. Zonder jou had ik dit niet voor elkaar gekregen. We maken er een mooie toekomst van!

Allemaal bedankt!

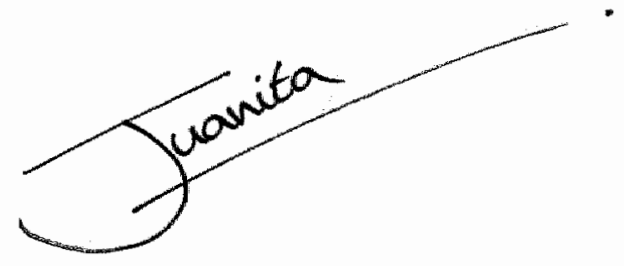




\section{List of publications}

\section{FULL PAPERS}

Vernooy $J H$, Kucukaycan $M$, Jacobs $J A$, Chavannes $N H$, Buurman WA, Dentener $M A$, and Wouters EF. Local and systemic inflammation in patients with chronic obstructive pulmonary disease: soluble tumor necrosis factor receptors are increased in sputum. Am J Respir Crit Care Med 2002;166:1218-1224.

Vernooy $\mathrm{JH}$, Dentener MA, van Suylen RJ, Buurman WA, and Wouters EFM. Longterm intratracheal lipopolysaccharide exposure in mice results in chronic lung inflammation and persistent pathology. Am / Respir Cell Mol Biol 2002;26:152159.

Vernooy $J H$, Dentener MA, van Suylen RJ, Buurman WA, and Wouters EF. Intratracheal instillation of lipopolysaccharide in mice induces apoptosis in bronchial epithelial cells: no role for tumor necrosis factor-alpha and infiltrating neutrophils. Am / Respir Cell Mol Biol 2001;24:569-576.

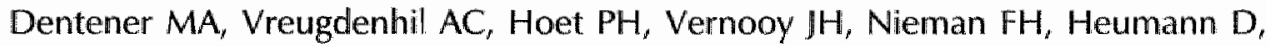
Janssen YM, Buurman WA, and Wouters EF. Production of the acute-phase protein lipopolysaccharide-binding protein by respiratory type II epithelial cells: implications for local defense to bacterial endotoxins. Am / Respir Cell Mol Biol 2000:23:146-153.

Stalman M, Koskamp A, Luderer R, Vernooy JHJ, Wind JC, Wullems GJ, and Croes AF. Regulation of anthraquinone biosynthesis in cell cultures of Morinda citrifolia. J. Plant Physiol 2003; In press.

Vernooy JH, Lindeman J, Jacobs JA, Hanemaaijer $R$, and Wouters EF. Increased activity of MMP-8 and MMP-9 in induced sputum from patients with COPD. Am / Respir Crit Care Med 2003; Submitted.

Vernooy JH, Dentener MA, Buurman WA, and Wouters EF. Local and systemic acute-phase response in COPD. Eur Resp / 2003; Submitted.

Vernooy $\mathrm{JH}$, Reynaert $\mathrm{N}$, Wolfs TGAM, De Vries B, Dentener MA, Buurman WA, and Wouters EF. Rapid expression of acute-phase reactants in lung after local LPS exposure in mice. Infect Immun 2003; Submitted.

Broekhuizen R, Vernooy JHJ, Schols AMWJ, Dentener MA, and Wouters EFM. Leptin as local inflammatory marker in COPD. Eur Resp / 2003; Submitted. 


\section{BOOK CONTRIBUTIONS}

Vernooy JHI, Dentener MA, Buurman WA, and E.F.M. W. 2002. Intratracheal instillation of lipopolysaccharide in mice results in increased hyaluronan deposition in the lung. In J.F. J.F. Kennedy, G.O. Phillips, P.A. Williams, and V.C. Hascall, editors. HYALURONAN - (Bio)Chemical, Medical and Clinical Aspects, ed. Woodhead, Cambridge.

Wouters EFM, Dentener MA, Vernooy JHJ, Pouw EM, Engelen MPKJ, and Creutzberg EC. 2003. AECOPD: a systemic disease? In N. Siafakis, N. Anthonisen, and D. Georgopoulos, editors. AE-COPD, ed. Marcel Dekker Inc., New York.

\section{ABSTRACTS (SELECTION)}

Vernooy JHJ, Küçükaycan $M$, Dentener MA, Buurman WA, and Wouters EFM. Local acute-phase response in subjects with stable COPD. Am. J. Resp. Crit. Care Med. 2002;165:A603.

Vernooy JHI, Reynaert N, Dentener MA, Buurman WA, and Wouters EFM. Intratracheal instillation of lipopolysaccharide in mice results in increased hyaluronan deposition in the lung. Am. J. Resp. Crit. Care Med. 2002;165:A757.

Vernooy $J \mathrm{HJ}$, Küçükaycan $\mathrm{M}$, Dentener MA, Buurman WA, and Wouters EFM. Differences in soluble TNF-receptors 55 and 75 in induced sputum from patients with COPD and healthy controls. Am. J. Resp. Crit. Care Med. 2002;165:A824.

Vernooy JHJ, Dentener MA, Koerts-De Lang E, Van Suylen RJ, Buurman WA, and Wouters EFM. Chronic pulmonary inflammation induced by repeated ipoporysaccharide instmation in mice resur's in coexistenc emphysema and bronchitis. Am. J. Resp. Crit. Care Med. 2000;161:A181.

Vernooy JHI, Dentener MA, Van Suylen RI, Buurman WA, and Wouters EFM. Intratracheal instillation of lipopolysaccharide induces apoptosis in bronchial epithelial cells. Am. J. Resp. Crit. Care Med. 1999;159:A697.

Vernooy JHJ, Lindeman J, Jacobs JA, Hanemaaijer R, and Wouters EFM. Increased activity of MMP-8 and MMP-9 in induced sputum from patients with mild-tomoderate COPD. Am. J. Resp. Crit. Care Med. 2003; In press.

Broekhuizen R, Vernooy JHJ, Schols AMWJ, Dentener MA, and Wouters EFM. The interaction between leptin and inflammatory markers in induced sputum in patients with moderate COPD. Eur Resp J 2002;20:404S.

Möller $\mathrm{GM}$, Vernooy $\mathrm{JH} \|$, and Wouters EFM. Increased expression of Granzyme A 
in patients with COPD. Am. J. Resp. Crit. Care Med. 2002;165:A603.

Hageman G], Larik I, Vernooy JHI, Dentener MA, Bast $A$, and Wouters EFM. Exposure of lung epithelial cells to reactive oxygen species induces PARP-1 activation in vitro and in vivo. Am. J. Resp. Crit. Care Med. 2002;165:A602.

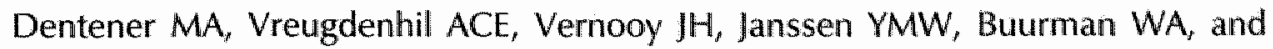
Wouters EFM. Production of the acute-phase protein LPS binding protein (LBP) by alveolar type II epithelial cells. Am. J. Resp. Crit. Care Med. 1999;159:A179. 


\section{Curriculum vitae}

Juanita Vernooy was born on November 29th, 1973 in Heerlen, The Netherlands. She attended secondary school (Gymnasium-B) at the "Sint-lanscollege" in Hoensbroek from 1986 till 1992. In the same year, she started the study Biology at the Faculty of Science, Mathematics and Computing Science, University of Nijmegen, and specialized in Physiology and Biochemistry. She graduated in 1997 on a research project performed at the Department of Molecular Plant Physiology, University of Nijmegen in close collaboration with the Department of Plant Physiology, Wageningen University, in which production of secondary metabolites was studied in transient and continuous cultures of Morinda citrifolia root cells.

In 1997 she started with her PhD project at the Department of Respiratory Medicine (formerly known as Pulmonology), Maastricht University, under supervision of Prof. dr. E.F.M. Wouters. The research presented in this thesis was financed by Glaxo Wellcome, The Netherlands, and was performed in close collaboration with the Department of General Surgery, Mastricht University, under supervision of Prof. dr. W.A. Buurman. Nowadays, she is working as Postdoc at the Department of Respiratory Medicine, Maastricht University. 